EFEITO DO REFINO DO TAMANHO DE GRÃO PELA ADIÇÃO DE Hf NAS PROPRIEDADES MECÂNICAS DE TRAÇÃO E IMPACTO DO AÇO HADFIELD

São Paulo 


\section{EFEITO DO REFINO DO TAMANHO DE GRÃO PELA ADIÇÃO DE Hf NAS PROPRIEDADES MECÂNICAS DE TRAÇÃO E IMPACTO DO AÇO HADFIELD}

Dissertação de mestrado apresentada à Escola Politécnica da Universidade de São Paulo para a obtenção do título de Mestre em Ciências.

Área de Concentração:

Engenharia metalúrgica e materiais.

Orientador: Prof. Dr. Cesar Roberto de Farias Azevedo.

São Paulo 
Este exemplar foi revisado e corrigido em relação à versão original, sob responsabilidade única do autor e com a anuência de seu orientador.

São Paulo, de de

Assinatura do autor:

Assinatura do orientador:

Catalogação-na-publicação

Venturelli, Bianka Nani

Efeito do refino do tamanho de grão pela adição de $\mathrm{Hf}$ nas propriedades mecânicas de tração e impacto do aço Hadfield / B. N. Venturelli -- versão corr. -São Paulo, 2018.

$151 \mathrm{p}$.

Dissertação (Mestrado) - Escola Politécnica da Universidade de São Paulo. Departamento de Engenharia Metalúrgica e de Materiais.

1.Aço Hadfield 2.Refino do tamanho de grão austenítico 3.Propriedades mecânicas de tração e impacto 4.Deformação plástica por maclação I.Universidade de São Paulo. Escola Politécnica. Departamento de Engenharia Metalúrgica e de Materiais II.t. 
Nome: VENTURELLI, Bianka Nani

Título: Efeito do refino do tamanho de grão pela adição de Hf nas propriedades mecânicas de tração e impacto do aço Hadfield.

\author{
Dissertação apresentada à Escola Politécnica da \\ Universidade de São Paulo para obtenção do título \\ de Mestre em Ciências.
}

Aprovado em: 12/03/2018

Banca Examinadora

Prof. Dr. Cesar Roberto de Farias Azevedo

Instituição: PMT- EPUSP

Julgamento:

Prof. Dr. Amilton Sinatora

Instituição: PME- EPUSP

Julgamento:

Prof. Dr. Eduardo Albertin

Instituição: IPT

Julgamento: 


\section{AGRADECIMENTOS}

Ao Prof. Dr. Cesar Roberto de Farias Azevedo pela orientação, auxílio, discussões e paciência durante o desenvolvimento deste trabalho.

Ao Dr. Eduardo Albertin do Instituto de Pesquisas Tecnológicas (IPT) pelas discussões e auxílio em diversas etapas do desenvolvimento deste trabalho.

Ao Instituto de Pesquisas Tecnológicas (IPT) pelo apoio na realização deste trabalho permitindo a utilização das instalações e equipamentos de pesquisa.

Aos pesquisadores do IPT que sempre se dispuseram a auxiliar em todos os momentos de necessidade.

Aos técnicos do IPT sem os quais não seria possível a realização deste trabalho. Em especial ao Alberto e o Márcio pela realização das corridas experimentais, e a Alzira e o Edison pelo auxilio na preparação de amostras para a caracterização microestrutural.

Ao Conselho Nacional de Desenvolvimento Científico e Tecnológico (CNPQ) pela concessão da bolsa de mestrado e pelo apoio financeiro.

A Fundação de Apoio ao IPT (FIPT) pelo apoio cientifico e financeiro.

Agradeço aos meus familiares, em especial meus pais e irmãos, que sempre estiveram ao meu lado. 


\section{RESUMO}

Este trabalho consiste no estudo das propriedades mecânicas de tração e impacto do aço Hadfield refinado com $\mathrm{Hf}$ em relação ao aço Hadfield sem refino. Foram realizadas simulações no software Thermo-Calc para caracterizar o caminho de solidificação e a evolução microestrutural do aço Hadfield (composição química de $13 \%$ de $\mathrm{Mn}, 1,2 \%$ de $\mathrm{C}$ e $0,65 \%$ de $\mathrm{Si}$ ). Foram fundidos os corpos de prova de aço Hadfield sem refino e refinado pela adição de $\mathrm{Hf}$, ambos com a composição química de acordo com a norma ASTM A128 - grau B2. Os corpos de prova foram submetidos ao tratamento térmico de solubilização à temperatura de $1120^{\circ} \mathrm{C}$ por 10 horas. A caracterização macroestrutural mostrou que o aço Hadfield com adição de Hf apresenta tamanho do grão austenítico cinco vezes menor $(600 \mu \mathrm{m})$ do que o aço Hadfield sem refino (de $3000 \mu \mathrm{m}$ para $600 \mu \mathrm{m}$ ), sendo que este resultado foi confirmado pela técnica de EBSD (Electron backscatter diffraction). Os resultados do ensaio de tração dos corpos de prova para as duas condições mostraram que as propriedades de limite de escoamento (6\%), tenacidade $(88 \%)$, resistência à tração $(37 \%)$, e do coeficiente de encruamento $(30 \%)$ do aço Hadfield refinado aumentaram em relação ao aço Hadfield sem refino. A energia absorvida no impacto aumentou de $156 \mathrm{~J} / \mathrm{cm}^{2}$ para $179 \mathrm{~J} / \mathrm{cm}^{2}$ com o refino do tamanho de grão austenítico. A lei de Hall-Petch foi utilizada para explicar o efeito do refino de grão no limite de escoamento, mas não pode ser usada para explicar o aumento na resistência a tração, tenacidade, e as mudanças no coeficiente de encruamento. A caracterização microestrutural das amostras rompidas em tração e impacto mostrou que a fração de maclas aumentou em $46 \%$ (em tração) e $45 \%$ (no impacto) para o aço Hadfield refinado em comparação com o aço Hadfield sem refino. Os resultados da caracterização microestrutural dos corpos de prova rompidos no ensaio de tração e impacto indicam que o mecanismo de deformação plástica por maclação foi mais atuante com o refino do grão austenítico.

Palavras - chave: Aço Hadfield, refino do grão austenítico, propriedades mecânicas de tração e impacto, técnica de EBSD, deformação por maclação. 


\begin{abstract}
The tensile and impact properties of Hf-refined Hadfield steel were compared to the properties of non-refined Hadfield steel. Simulations in Thermo-Calc software were made in order to study the solidification and microstructural evolution of a Hadfield steel (13\% Mn, 1.2\% C and $0.65 \% \mathrm{Si})$. Samples of nonrefined and refined Hadfield steel (with addition of $0.1 \%$ of $H$ ), both with chemical composition as described in ASTM A128- grade B2, were cast and subjected to a solution heat treatment at $1100^{\circ} \mathrm{C}$ for 10 hours, followed by water quenching. Macrostructural characterization showed that the refined Hadfield steel featured an austenitic grain size equal to $600 \mu \mathrm{m}$, five times smaller than the grain size of the non-refined Hadfield steel $(3000 \mu \mathrm{m})$. These results were confirmed by EBSD (Electron backscatter diffraction) analysis. The tensile test results showed an increase in the values of the yield stress $(6 \%)$, the fracture toughness $(88 \%)$, the tensile strength $(37 \%)$ and the strain hardening coefficient (30\%) with the reduction on the austenitic grain size from $3000 \mu \mathrm{m}$ to $600 \mu \mathrm{m}$. Additionally, the value of the absorbed energy of the impact test was improved from $156 \mathrm{~J} / \mathrm{cm}^{2}$ to $179 \mathrm{~J} / \mathrm{cm}^{2}$ with reduction on the grain size. The Hall-Petch law was used to explain the small increase of $8 \%$ in the value of the yield stress with the grain refinement, but this law could not be used to explain the increase in the values of the fracture toughness, the tensile strength and the strain hardening coefficient. The microstructural characterization of the fractured testpieces after tensile and impact testing showed that the values of the fraction of mechanical twins (definer) in the plastically deformed microstructure near the fracture surfaces of the refined condition increased by $45 \%$ when compared to the non-refined condition. These results indicated that the austenitic grain refinement of the Hadfield steel changed the plastic deformation mechanism, favoring the activation of the plastic deformation by twinning mechanism and, therefore, increasing the values of the fracture toughness $(\sim 88 \%)$, the ultimate tensile strength $(\sim 30 \%)$, the strain-hardening coefficient $(\sim 30 \%)$ and the absorbed energy during Charpy-test ( 15\%).
\end{abstract}

Key-words: Hadfield steel, refinement of austenitic grain size, tensile and impact properties, EBSD analysis, twinning deformation. 


\section{LISTA DE ILUSTRAÇÕES}

Figura 1 - Diagrama de equilíbrio do sistema Fe-Mn indicando o campo das fases líquido, $\delta, \gamma+\alpha, \alpha, \alpha$ (Mn), $\gamma(\mathrm{Fe}, \mathrm{Mn}), \beta(\mathrm{Mn})$ e $\delta(\mathrm{Mn})$

Figura 2 - Diagrama experimental pseudo-binário do aço Hadfield com $13 \% \mathrm{Mn}$, indicando o campo das fases_ $y, y+M_{3} C, \alpha+\gamma, \alpha+\gamma+M_{3} C$ e $\alpha$ $+\mathrm{M} 3 \mathrm{C}$. 26

Figura 3 - Figura 3 - Seções isotérmicas do sistema ternário Fe-Mn-C à (a) $1000^{\circ} \mathrm{C}$, (b) $900^{\circ} \mathrm{C}$ e (c) $600^{\circ} \mathrm{C}$ indicando os campos das fases $\gamma-\mathrm{Fe}, \mathrm{y}-\mathrm{Mn}, \alpha-$ $\mathrm{Fe}, \alpha-\mathrm{Mn}, \mathrm{M}_{23} \mathrm{C}_{6}, \mathrm{M}_{15} \mathrm{C}_{4}, \mathrm{M}_{3} \mathrm{C}$ e $\mathrm{M}_{7} \mathrm{C}_{3}$.

Figura 4 - Projeção da curva liquidus do diagrama ternário Fe-Mn-C .29

Figura 5 - Micrografia do aço Hadfield no estado bruto de fundição, indicando a matriz austenítica com a presença de carbonetos contínuos interdendtríticos e a

perlita.

Figura 6 - Efeito de fragilização das precipitações de carbonetos eutéticos do tipo $\mathrm{M}_{3} \mathrm{C}$ em contornos de grãos na resistência ao impacto de aços Hadfield.31

Figura 7 - Diagrama TTT de decomposição da austenita para o aço Hadfield com $13 \%$ C

Figura 8 - Diagrama pseudo-binário do aço Hadfield com 13\% Mn mostrando os campos das fases $\gamma, \gamma+M_{3} C, \gamma+\alpha, \gamma+\alpha+M_{3} C$ e $\alpha+M_{3} C$.

Figura 9 - Tratamento térmico de perlitização do aço ao manganês austenítico .35

Figura 10 - Curva de tensão-deformação verdadeira característica do aço Hadfield em comparação com o ferro fundido cinzento $e$ aços ao carbono. 37

Figura 11 - Efeito do teor de C nas propriedades mecânicas do aço Hadfield. (a) Efeito do teor de $\mathrm{C}$ na resistência à tração $(\mathrm{MPa})$ e no limite de escoamento (MPa); (b) Efeito do teor de $\mathrm{C}$ no alongamento (\%) 39 
Figura 12 - Representação esquemática da deformação por escorregamento (a) em comparação com a maclação (b) em metais com estrutura cubica de face centrada (CFC). .43

Figura 13 - Representação esquemática da deformação por maclação em um cristal. .43

Figura 14 - Energia de falha de empilhando em função da temperatura para um aço TWIP. O diagrama mostra as regiões de ocorrência de cada mecanismo de deformação plástica da austenita (escorregamento, maclação e transformação martensitica). 45

Figura 15 - Figura esquemática do modelo de empilhamento de discordâncias no contorno de grão (obstáculo).

Figura 16 - Modelo esquemático dos contornos de grão atuando como fontes de discordâncias (b) Imagem de MET de liga metálica de Ti-Mo, com discordâncias sendo geradas nos contornos de grão. 48

Figura 17 - Modelo esquemático da distância de deslizamento em materiais com tamanhos de grãos (a) pequenos e (b) grandes. 49

Figura 18 - Representação esquemática do modelo proposto por Ashby (ASHBY, 1971) no qual (a) os grãos em materiais policristalinos deformam uniformemente e são formadas (b) vazios e superposições entre os grãos podendo ser corrigidos pela introdução de (c) e (d) discordâncias geométricas (GNDs) .50

Figura 19 - Gráfico indicando a dependência da resistência à fratura $\left(\mathrm{N} / \mathrm{mm}^{2}\right)$, alongamento (\%) e energia absorvida no impacto $\left(\mathrm{J} / \mathrm{cm}^{2}\right)$ com o tamanho de grão no aço ao manganês austenítico 110G13L...........................................52 Figura 20 - Curvas de tensão (MPa) - deformação do aço Hadfield com tamanhos de grão de 100, 300 e $1000 \mu \mathrm{m}$. .53

Figura 21 - Relação entre o desajuste do parâmetro de rede e do super resfriamento para diferentes agentes nucleadores (inoculantes) em aços. 54 
Figura 22 - Micrografias do (a) aço $S 45 \mathrm{C}$ sem adição de Ti e B e; (b) com adição de 0,2\% em mol de Ti e 0,4\% em mol de B. Ataque químico: Nital 0,2\%. Aumento original de $50 x$ .55

Figura 23 - Figura esquemática do efeito de ancoramento provocado pelas partículas de $\mathrm{TiB}_{2}$ e inclusões de $\mathrm{TiC}$ e $\mathrm{FeB}_{2}$ nas posições interdendríticas da austenita. 56

Figura 24 - Comparação entre (a) aço Hadfield com adição de Ce e (b) aço Hadfield com adição de $\mathrm{Hf}$. 57

Figura 25 - Forno de indução Inducto 50 utilizado para as corridas experimentais. .59

Figura 26 - (a) Peça do tipo "keel block" com 12,5 cm de comprimento; (b) Peça fundida no formato de bloco $60 \times 40 \times 80 \mathrm{~mm}$. 60

Figura 27 - Morfologias do háfnio metálico utilizado no processo de refino microestrutural de peças fundidas de aço Hadfield refinado no formato de (a) cavacos (espessura de $2 \mathrm{~mm}$ ); (b) placas (dimensões de $8 \times 2 \times 8 \mathrm{~mm}$ ).

Figura 28 - Copos de análise térmica (com $50 \mathrm{~mm}$ de altura e $30 \mathrm{~mm}$ de diâmetro) com capacidade nominal de $300 \mathrm{~g}$ utilizados como molde para as corridas experimentais teste

Figura 29- (a) Espectro da microanálise química EDS da placa de $\mathrm{Hf}$ e (b) Imagem de MEV da região da placa de Hf em que a microanálise química EDS foi realizada .65

Figura 30 - Curvas de tratamento térmico de solubilização das peças de aço Hadfield .66

Figura 31 - Figura esquemática da região de extração das amostras para caracterização macro e microestrutural.

Figura 32 - Métodos de medidas do tamanho de grão. (a) Tamanho de grão determinado pela média entre a maior e menor dimensão do grão; (b) Método do intercepto linear segundo a norma ASTM E112-96 .68 
Figura 33 - Métodos para a determinação da fração pontual (a) e em área (b) das microporosidades presentes nos corpos de prova extraídos do bloco e "keel block" de aço Hadfield. .70

Figura 34 - Linhas de Kikuchi formadas pela difração dos elétrons retro espalhados em amostra de níquel. .71

Figura 35 - Equipamento da técnica de EBSD. (a) Componentes do equipamento de EBSD e (b) visão ampliada da câmara do MEV indicando a amostra inclinada a $70^{\circ}$ e a tela de fósforo. .72

Figura 36 - Figura de polos invertida (IPF) para o sistema cúbico .73

Figura 37 - Figura esquemática da região de extração dos corpos de prova para 0 ensaio de tração (a) e para 0 ensaio de impacto. 74

Figura 38 - Corpo de prova para ensaio de impacto com dimensões de $55 \times 10$ x $10 \mathrm{~mm}$ segundo a norma ASTM E23. .75

Figura 39 - Corpo de prova para ensaio de tração segundo a norma ASTM E8M.

Figura 40 - Fração em massa do liquido em função da temperatura considerando-se o modelo de Scheil. .78

Figura 41 - Fração molar de sólido considerando-se a solidificação pelo modelo de Scheil. A condição de solidificação de equilíbrio é mostrada pela linha pontilhada. 78

Figura 42 - Redistribuição dos solutos (Mn, C e Si) na fase líquida considerando-se o modelo de solidificação de Scheil. .79

Figura 43 - Fração volumétrica das fases $\mathrm{M}_{5} \mathrm{C}_{2}$, ferrita, cementita, austenita e liquido em função da temperatura $\left({ }^{\circ} \mathrm{C}\right)$. .80

Figura 44 - Evolução microestrutural, segundo o modelo de Scheil, do aço Hadfield com adição de Hf. (a) Fração em massa das fases $M_{7} C_{3}, M_{5} C_{2}$, ferrita, cementita, austenita e líquido em função da temperatura $\left({ }^{\circ} \mathrm{C}\right)$; (b) Detalhe da formação de fase rica em $\mathrm{Hf}$ em temperatura de $1472^{\circ} \mathrm{C}$; (c) Gráfico indicando 
a fração em massa do $\mathrm{Hf}$ presente no líquido, cementita, ferrita, $M_{7} C_{3}, M_{5} C_{2}$, austenita, e uma segunda fase CFC em função da temperatura $\left({ }^{\circ} \mathrm{C}\right)$.

Figura 45 - Comparação entre (a) zona coquilhada e colunar do aço Hadfield sem refino e (b) região próxima à superfície do aço Hadfield refinado. Aumento original de 7,3x. Ataque químico: Nital 6\%. Exame em lupa. .84

Figura 46 - Comparação entre (a) região equiaxial do aço Hadfield sem refino e (b) região central do aço Hadfield refinado. Aumento original de 7,3x. Ataque químico: Nital 6\%. Exame em lupa. .85

Figura 47 - Aço Hadfield sem refino após tratamento térmico de solubilização à $1120^{\circ} \mathrm{C}$ por 10 horas. Aumento original de 50x. Ataque químico: Nital $3 \%$. Microscópio óptico.

Figura 48 - Aço Hadfield refinado com $0,1 \% \mathrm{Hf}$ após tratamento térmico de solubilização à $1120^{\circ} \mathrm{C}$ por 10 horas. Aumento original de $100 \mathrm{x}$. Ataque químico: Nital 3\%. Microscópio óptico.

Figura 49 - Resultados de microanálise EDS das partículas presentes na microestrutura do aço Hadfield sem refino. (a) Imagem de MEV da partícula na qual a microanálise de EDS foi realizada; (b) Espectro de microanálise EDS desta partícula. .88

Figura 50 - Aço Hadfield sem refino. (a) Resultado da técnica EBSD na região colunar do aço Hadfield sem refino. Ataque químico: Nital 3\%; (b) Indicação dos grãos marcados em (a) na figura de polo inversa para o sistema cúbico .90

Figura 51 - Aço Hadfield sem refino. (a) Resultado da técnica EBSD na região central (grãos equiaxiais) do aço Hadfield sem refino. Ataque químico: Nital 3\%; (b) Indicação dos grãos marcados em (a) na figura de polo inversa para o sistema cúbico. 91

Figura 52 - Aço Hadfield refinado com 0,1\% Hf. (a) Resultado da técnica EBSD na região central do aço Hadfield refinado com Hf. Ataque químico: Nital $3 \%$; (b) Indicação dos grãos marcados em (a) na figura de polo inversa para o sistema cúbico 
Figura 53 - Gráfico da tensão x deformação verdadeira do aço Hadfield sem refino para os três corpos de prova ensaiados por tração

Figura 54 - Gráfico da tensão x deformação verdadeira do aço Hadfield refinado com $0,1 \% \mathrm{Hf}$ para os três corpos de prova ensaiados por tração. .95

Figura 55 - Gráfico da tensão x deformação verdadeira do aço Hadfield sem refino e refinado com $0,1 \% \mathrm{Hf}$ ensaiados por tração.

Figura 56 - Aspecto geral da superfície de fratura do aço Hadfield sem refino (a) e aço Hadfield refinado com $0,1 \%$ Hf (b) após o ensaio de tração .99

Figura 57 - Aspecto geral da superfície lateral dos corpos de prova de aço Hadfield rompidos no ensaio de tração, (a) aço Hadfield sem refino e (b) aço Hadfield refinado 100

Figura 58 - Fractografias do aço Hadfield sem refino após ruptura em ensaio de tração, corpo de prova 2, MEV; (a) Fratura dúctil com a presença de alvéolos, 800x; (b) Maclas de deformação, 2000

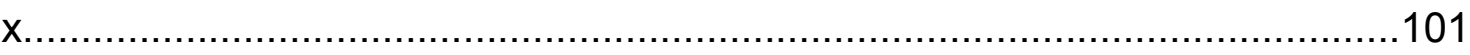

Figura 59 - Fractografias do aço Hadfield sem refino após ruptura em ensaio de tração, corpo de prova 2, MEV; (a) Fratura dúctil com a presença de alvéolos, 10000 x; (b) Maclas de deformação, 10000 x

Figura 60 - Micrografia do corpo de prova de aço Hadfield rompido no ensaio de tração, região próxima à superfície de fratura. (a) aço Hadfield sem refino; (b) aço Hadfield refinado. Aumento original de 100X. Sem ataque químico. Exame em Microscópio óptico 103

Figura 61 - Microestrutura próxima da região da fratura das amostras tracionadas de aço Hadfield sem refino (grãos equiaxiais) mostrando a presença de maclas de deformação, seção transversal, técnica de EBSD. 105 
Figura 62 - Microestrutura próxima da região da fratura das amostras tracionadas de aço Hadfield refinado mostrando a presença de maclas de deformação plástica, seção transversal, técnica de EBSD 106

Figura 63 - Micrografia do corpo de prova de aço Hadfield rompido no ensaio de tração, seção paralela à superfície de fratura, ataque químico com Nital $3 \%$; (a) aço Hadfield sem refino, aumento original ; (b) aço Hadfield refinado, aumento de 50x. Microscópio óptico. 108

Figura 64 - Microporosidades presentes no aço Hadfield sem refino, 100x, sem ataque químico. (a) Corpo de prova extraído do "Keel block" e (b) Corpo de prova extraído do bloco. 110

Figura 65- Microporosidades presentes no aço Hadfield refinado, 100x, sem ataque químico. (a) Corpo de prova extraído do "Keel block" e (b) Corpo de prova extraído do bloco. 111

Figura 66 - Superfície de fratura após o ensaio de impacto do cp1 do aço Hadfield sem refino (a) e refinado com $\mathrm{Hf}$ (b) extraídos do bloco. Aumento original de 10x. Exame em lupa. 115

Figura 67 - Superfície de fratura após o ensaio de impacto do cp1 do aço Hadfield sem refino (a) e refinado com $\mathrm{Hf}(\mathrm{b})$, amostra extraída do "keel block". Aumento original de 10x. Exame em lupa. 116

Figura 68 - Fractografias da superfície de fratura do aço Hadfield sem refino submetido ao ensaio de impacto (cps extraídos do "keel block"). (a) Maclas de deformação, aumento original de; (b) Fratura dúctil com a presença de alvéolos, aumento original de 2000x. Exame em MEV 117

Figura 69 - Fractografias da superfície de fratura do aço Hadfield refinado submetido ao ensaio de impacto (cps extraídos do "keel block"). (a) Maclas de deformação, aumento original de 4000x; (b) Fratura dúctil com a presença de alvéolos, aumento original de 4000x. Exame em MEV. 119

Figura 70 - Resultados de MEV da superfície de fratura do aço Hadfield com $0,1 \% \mathrm{Hf}$ submetido ao ensaio de impacto, utilizando (a) imagem de elétrons secundários, (b) imagem de elétrons retro-espalhados e (c) Espectro de 
microanálise química EDS da partícula encontrada nos resultados de MEV. Aumento original de 20000x

Figura 71 - Micrografia do corpo de prova de aço Hadfield extraído do bloco, rompido no ensaio de impacto. (a) aço Hadfield sem refino, aumento original de 50x; (b) aço Hadfield refinado, aumento original de 100x. Microscópio óptico, sem ataque químico 123

Figura 72 - Micrografia do corpo de prova de aço Hadfield sem refino rompido no ensaio de impacto. Ataque Nital 5\%. (a) Região próxima ao entalhe. Aumento original de 50x; (b) Detalhe dos grãos austeníticos. Aumento original de 200x. Microscópio óptico. 124

Figura 73 - Micrografia do corpo de prova de aço Hadfield refinado com 0,1\% $\mathrm{Hf}$ rompido no ensaio de impacto. (a) Região próxima ao entalhe. Aumento original de 50x; (b) Detalhe dos grãos austeníticos. Ataque Nital 5\%. Aumento original de 500x. Microscópio óptico. 125

Figura 74 - Curvas de tensão (MPa) - deformação do aço Hadfield com tamanhos de grão de 100, 300 e $1000 \mu \mathrm{m}$. 130

Figura 75 - Figura esquemática mostrando os contornos das maclas de deformação subdividindo os grãos da austenita e reduzindo o caminho livre médio para o movimento das discordâncias. 134

Figura 76 - Mapa da energia de falha de empilhamento (EFE) em função do teor de $\mathrm{Mn}$ e $\mathrm{C}$ presentes na composição química à temperatura de $27^{\circ} \mathrm{C}$ 134

Figura 77 - Micrografia do aço Hadfield após o ensaio de tração à $20^{\circ} \mathrm{C}$ para a deformação de (a) 0,06, (b) 0,18 e (c) 0,30. Observa-se a presença de maclas de deformação que aumentam com o aumento da deformação. 135 


\section{LISTA DE TABELAS}

Tabela 1 - Composição química dos aços Hadfield, segundo a norma ASTM A128. 5

Tabela 2 - Propriedades mecânicas do aço Hadfield (13\%Mn) 20

Tabela 3 - Plano e direção cristalográfica preferencial para a maclação nas estruturas cristalinas do tipo CFC, CCC e HC. .24

Tabela 4 - Propriedades mecânicas do aço Hadfield com adição de Hf. 39

Tabela 5 - Matéria prima utilizada para a preparação das corridas experimentais de aço Hadfield.

Tabela 6 - Resumo das corridas experimentais para obtenção do aço Hadfield grau B2 da norma ASTM A128 refinado com $\mathrm{Hf}$.

Tabela 7 - Composição química das amostras de aço Hadfield. 46

Tabela 8 - Tamanho de grão austenítico do aço Hadfield sem refino e refinado com $0,1 \% \mathrm{Hf}$. 75

Tabela 9 - Propriedades de tração do aço Hadfield sem refino. .78

Tabela 10 - Propriedades de tração do aço Hadfield refinado com 0,1\% Hf.... 78 Tabela 11 - Comparação entre as propriedades de tração do aço Hadfield sem refino e do aço Hadfield refinado com $0,1 \% \mathrm{Hf}$ tomando-se os valores médios. 79

Tabela 12 - Densidade de maclas e do espaçamento entre as maclas para o aço Hadfield sem refino.

Tabela 13 - Densidade de maclas e do espaçamento entre as maclas para o aço Hadfield refinado

Tabela 14 - Fração pontual e em área e microporosidades presentes nos cps de aço Hadfield sem refino e refinado extraídos do "bloco" e "keel block". .92

Tabela 15 - Energia absorvida no ensaio de impacto $\left(\mathrm{J} / \mathrm{cm}^{2}\right)$ do aço Hadfield sem refino. .95 
Tabela 13 - Energia absorvida no ensaio de impacto $\left(\mathrm{J} / \mathrm{cm}^{2}\right)$ do aço Hadfield refinado com $0,1 \% \mathrm{Hf}$. 96

Tabela 17 - Densidade de maclas e do espaçamento entre as maclas para o aço Hadfield sem refino. 108

Tabela 18 - Densidade de maclas e do espaçamento entre as maclas para o aço Hadfield refinado. 108

Tabela 19 - Comparação entre os parâmetros da equação de Hall-Petch para o aço Hadfield e o aço austenítico (composição química de 18\% de $\mathrm{Cr}, 14 \%$ de $\mathrm{Ni}, 4 \%$ de $\mathrm{Mn}$ e $0,5 \%$ de Si) da literatura. 113 


\section{SUMÁRIO}

1. INTRODUÇÃO

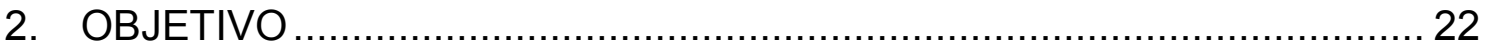

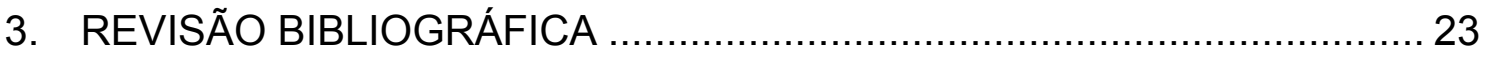

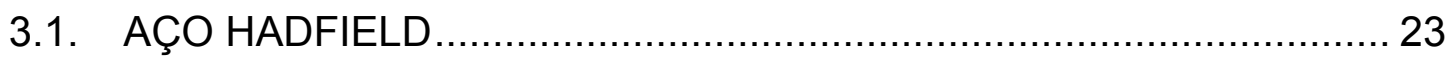

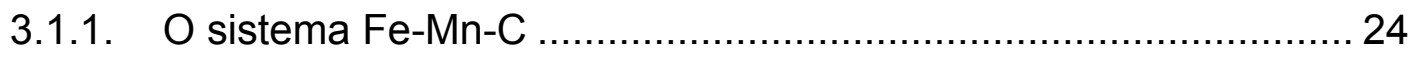

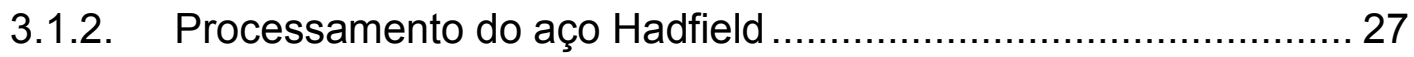

3.1.3. Propriedades mecânicas do aço Hadfield ..................................... 36

3.2. EFEITO DO TAMANHO DE GRÃO NAS PROPRIEDADES MECÂNICAS

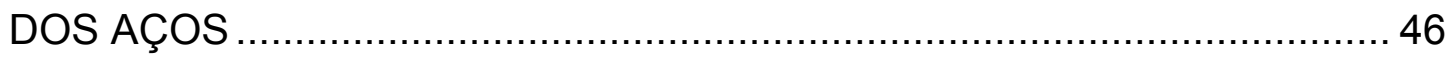

3.2.1 Refino do tamanho do grão austenítico em aço Hadfield .............. 54

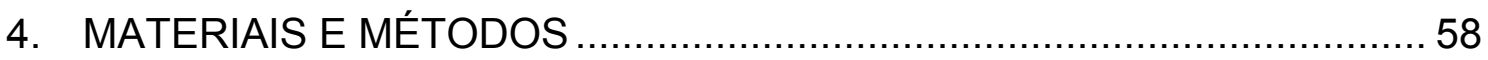

4.1. PRODUÇÃO DOS CORPOS DE PROVA DE AÇO HADFIELD ............ 58

4.1.1. Simulações microestruturais de solidificação usando o software

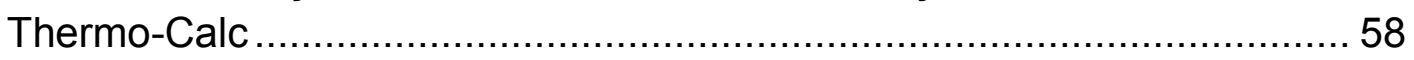

4.1.2. Fundição dos corpos de prova ............................................... 58

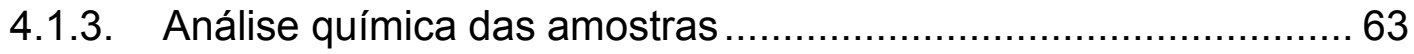

4.5. CARACTERIZAÇÃO MACRO E MICROESTRUTURAL .......................65

4.5.1. Difração de elétrons retroespalhados (EBSD) ................................ 71

4.6. USINAGEM DOS CORPOS DE PROVA PARA ENSAIOS

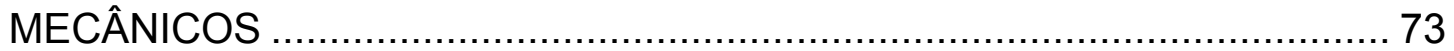

4.7. ENSAIO DE IMPACTO CHARPY COM ENTALHE EM "V" DE

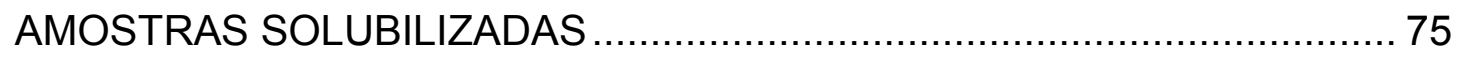

4.8. ENSAIO DE TRAÇÃO DE AMOSTRAS SOLUBILIZADAS................ 75

4.9. ENSAIOS FRACTOGRÁFICOS DOS CORPOS DE PROVA DE IMPACTO CHARPY E DO ENSAIO DE TRAÇÃO ………………............. 76

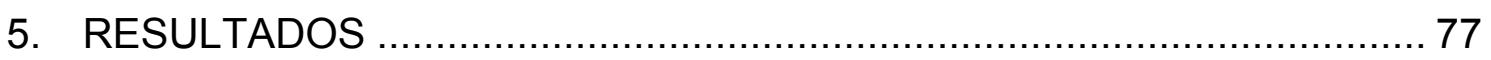

5.1 SIMULAÇÕES MICROESTRUTURAIS DE SOLIDIFICAÇÃO USANDO

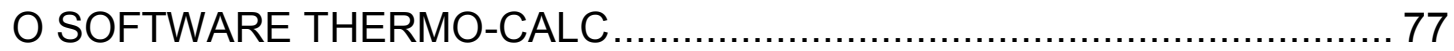

5.2 CARACTERIZAÇÃO MACRO E MICROESTRUTURAL DAS AMOSTRAS FUNDIDAS E DAS AMOSTRAS SOLUBILIZADAS: COMPARAÇÃO DA CONDIÇÃO SEM REFINO COM A CONDIÇÃO REFINADA.

5.2.1. Determinação do tamanho de grão austeníticos .......................... 93 
5.3 RESULTADOS DO ENSAIO DE TRAÇÃO DAS AMOSTRAS

SOLUBILIZADAS

5.3.1. Fractografias dos corpos de prova rompidos no ensaio de tração .. 98 5.4. RESULTADOS DO ENSAIO DE IMPACTO DAS AMOSTRAS SOLUBILIZADAS

5.4.1. Resultados do ensaio de impacto Charpy das amostras solubilizadas 112

5.4.2. Fractografias dos corpos de prova rompidos no ensaio de impacto Charpy 114

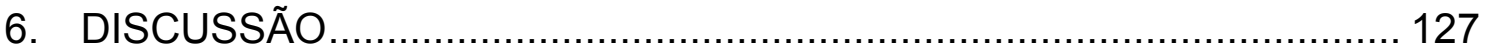

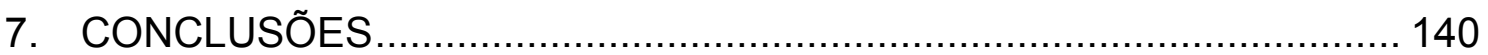

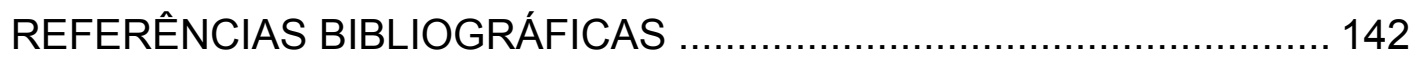




\section{INTRODUÇÃO}

O aço manganês austenítico foi inventado por Sir Robert Abbott Hadfield, em 1882. Foram testadas as adições de 7 a $20 \%$ de manganês ao aço carbono com o objetivo principal de aumentar as propriedades mecânicas dos aços carbono convencionais. Foi utilizada uma razão entre os teores de carbono e manganês de 1/10 (HADFIELD, 1882). Os aços ao Mn com a composição química na faixa de $1-1,4 \%$ C e $10-14 \%$ Mn destacaram-se por apresentarem um aumento significativo nas propriedades mecânicas de resistência à tração, de resistência ao desgaste e de tenacidade à fratura quando comparados aos aços carbono (TWEEDALE, 1985; HADFIELD, 1882).

O manganês atua como estabilizador da fase austenita nos aços, reduzindo a temperatura de início da transformação martensítica (Ms), e atrasando ou evitando a reação de decomposição da austenita durante o resfriamento do aço (GIRALDO, 2012). Os aços Hadfield possuem elevada capacidade de endurecimento em serviço pela deformação plástica da austenita (AVERY, 1961; ASM Metals Handbook, 1993). O encruamento aumenta a dureza superficial destes aços para valores em torno de $400 \mathrm{HB}$, aumentando ainda mais a sua resistência à abrasão, com manutenção da elevada tenacidade do material (energia absorvida no impacto de $110-169 \mathrm{~J} / \mathrm{cm}^{2}$ ) em outras regiões da peça (LIMA, 2011; FUOCO, 2007).

O aço Hadfield apresenta elevada tenacidade para seu uso em aplicações envolvendo desgaste abrasivo e impacto elevado, nas quais não podem ser utilizados materiais como ferro fundido branco de alto cromo e aços martensíticos (FUOCO, 2007). Dessa forma, o aço Hadfield é utilizado na indústria de mineração, em aplicações como a fabricação de mandíbulas e giratórios na britagem primária de minérios; martelos de fragmentação de minérios e de sucatas; e na indústria ferroviária em aplicações que envolvem a fabricação de desvios e cruzamentos ferroviários (SUBRAMANYAM; SWANSIGER; AVERY, 1990). A indústria de mineração tem desempenho fundamental na economia do Brasil, participando com $3 \%$ a $4 \%$ do PIB, e $20 \%$ do total de exportações, gerando 175 mil empregos diretos na mineração e 2,2 milhões na indústria de transformação mineral, o equivalente a $8 \%$ dos 
empregos do setor produtivo no ano de 2012 (SANTANA, 2012). Os aços Hadfield apresentam maior quantidade em peso do elemento de liga Mn (1114\%). A produção mundial do minério de manganês em 2011 atingiu 14,5 Mt em metal contido e o Brasil ocupa a quinta posição no ranking dos países produtores, possuindo $9 \%$ do total produzido no mundo, sendo estratégico o aumento do uso de aplicações contendo este elemento de liga (SANTANA, 2012).

A melhoria das propriedades mecânicas de resistência ao desgaste e tenacidade dos aços Hadfield é fundamental para elevar a vida útil dos componentes de engenharia, com ganhos na eficiência do setor de mineração. Existe a possibilidade de aperfeiçoar estas propriedades e a vida útil destes componentes pela redução do tamanho de grão austenítico, sendo este o único meio de aumentar o limite de escoamento sem reduzir a tenacidade de ligas metálicas (CALLISTER, 2009; MORRIS, 2001; CHUNG, 2006; LLEWELLYN, 2013).

Neste contexto, Haakonsen (HAAKONSEN, 2009) estudou o efeito da adição de cério $(0,03-0,12 \%)$ como refinador do grão austenítico no aço Hadfield com 1,42\% C e 19,5\% Mn. Seus resultados de refino do tamanho do grão não foram significativos. Em 2012, Limooei et al (LIMOOEl et al, 2012) estudaram o efeito do titânio $(0,05 \%$ e $0,1 \%$ em peso $)$ na tenacidade e na resistência ao desgaste do aço Hadfield com 1,25\% C e 12\% Mn. Após o tratamento térmico de solubilização, verificou-se a redução de $50 \%$ no tamanho de grão austenítico, de $150 \mu \mathrm{m}$ para $60 \mu \mathrm{m}$.

O uso do háfnio como refinador do grão austenítico é descrito em patente europeia (OGUIZA, 2012). O háfnio é adicionado em quantidades de 0,01-0,1\% em peso num aço Hadfield com 1,2\% C e 12,5\% Mn. A adição de háfnio pode ser realizada depositando-o nos moldes, na concha de fundição e no jato durante o vazamento (OGUIZA, 2012). No entanto, a metodologia não é descrita de forma detalhada. A proposta do presente trabalho é a obtenção de corpos de prova fundidos do aço Hadfield com grão austeníticos refinado pelo tratamento do metal líquido com adições de $\mathrm{Hf}$, e o estudo das propriedades de tração e impacto do aço Hadfield refinado pela adição de $\mathrm{Hf}$ em comparação com o aço Hadfield sem refino. 


\section{OBJETIVO}

Os objetivos deste trabalho são:

1. Obtenção das amostras de aço Hadfield refinado pela adição de háfnio $(\mathrm{Hf})$;

2. Estudar o efeito do refino do tamanho de grão austenítico nas propriedades mecânicas de tração;

3. Estudar o efeito do refino do tamanho de grão austenítico na energia absorvida em ensaio de impacto Charpy;

4. Relacionar os resultados obtidos com a Equação de Hall-Petch;

5. Relacionar os resultados obtidos com os mecanismos de deformação plástica em aços Hadfield. 


\section{REVISÃO BIBLIOGRÁFICA}

\subsection{AÇO HADFIELD}

Após a Revolução Industrial, intensificou-se a pesquisa e manufatura de aços ao carbono com maiores teores de $\mathrm{Mn}$, $\mathrm{Al}$, Ti e $\mathrm{Si}$ com o objetivo de melhorar as propriedades mecânicas, facilitar os processos de soldagem e reduzir defeitos mecânicos do produto final. Em 1882, Sir Robert Abbot Hadfield estudou o efeito das adições de manganês e carbono no aço de interesse na cidade de Sheffield (Inglaterra) inspirado por uma viagem às fundições de aço nos EUA (HADFIELD, 1882). Foi utilizada uma razão de 1/10 entre os teores de carbono e manganês, sendo que os aços com teores de 11,4\% C e 10-14\% Mn apresentaram aumento nas propriedades mecânicas de tração, de resistência ao desgaste e de tenacidade à fratura quando comparados aos aços carbono (TWEEDALE, 1985).

As especificações de composição química do aço Hadfield são descritas pela norma ASTM A128 (tabela 1), mas nas ligas comerciais são utilizados teores de $\mathrm{Mn}$ acima de 14\% (FUOCO, 2007). Observa-se que os teores de C variam de 0,7 a $1,45 \%$, e os teores de $\mathrm{Mn}$ variam de $6-14 \%$. Os teores de $\mathrm{C}$ e a presença de elementos de liga tais como $\mathrm{Cr}$, Mo e Ni na composição química são os principais fatores que diferenciam os dez graus dos aços Hadfield. 
Tabela 1- Composição química dos aços Hadfield, segundo a norma ASTM A128.

\begin{tabular}{|c|c|c|c|c|c|c|c|}
\hline Grau & $\% \mathbf{C}$ & $\% \mathbf{M n}$ & $\% \mathbf{C r}$ & $\% \mathbf{M o}$ & $\% \mathbf{N i}$ & $\mathbf{S S}^{*}$ & $\% \mathbf{P}^{*}$ \\
\hline A & $1,05-1,35$ & 11 mínimo & - & - & - & 1 & 0,07 \\
\hline B-1 & $0,9-1,05$ & $11,5-14$ & - & - & - & 1 & 0,07 \\
\hline B-2 & $1,05-1,2$ & $11,5-14$ & - & - & - & 1 & 0,07 \\
\hline B-3 & $1,12-1,28$ & $11,5-14$ & - & - & - & 1 & 0,07 \\
\hline B-4 & $1,2-1,35$ & $11,5-14$ & - & - & - & 1 & 0,07 \\
\hline C & $1,05-1,35$ & $11,5-14$ & $1,5-2,5$ & - & - & 1 & 0,07 \\
\hline D & $0,7-1,3$ & $11,5-14$ & - & - & $3-4$ & 1 & 0,07 \\
\hline E-1 & $0,7-1,3$ & $11,5-14$ & - & $0,9-1,2$ & - & 1 & 0,07 \\
\hline E-2 & $1,05-1,45$ & $11,5-14$ & - & $1,8-2,1$ & - & 1 & 0,07 \\
\hline F & $1,05-1,35$ & $6-8$ & - & $0,9-1,2$ & - & 1 & 0,07 \\
\hline
\end{tabular}

*: teor máximo. Fonte: ASTM A128, 2012.

\subsubsection{O sistema Fe-Mn-C}

O sistema Fe-Mn-C foi amplamente estudado por Vogel et al (VOGEL et al, 1935), e Isobe (ISOBE, 1951) utilizando as informações termodinâmicas dos diagramas de equilíbrio binários $\mathrm{Fe}-\mathrm{Mn}, \mathrm{Fe}-\mathrm{C}$ e $\mathrm{Mn}-\mathrm{C}$, mas falharam na detecção de carbonetos que não são do tipo $\mathrm{M}_{3} \mathrm{C}$ e $\mathrm{Fe}_{3} \mathrm{C}$ (RAYNOR et al, 1988). O sistema Fe-Mn-C apresenta a fase líquido, os carbonetos $M_{3} C, M_{5} C_{2}$, $\mathrm{M}_{7} \mathrm{C}_{3}, \mathrm{M}_{23} \mathrm{C}_{6}$ e $\mathrm{M}_{4} \mathrm{C}_{1+\mathrm{X}}$, a grafita e as soluções sólidas de austenita $(\mathrm{Y})$, ferrita (a) e ferrita (ס) (MARATRAY, 1995).

A adição de manganês nos aços atua na estabilização da fase austenita à temperatura ambiente, atrasando ou evitando a reação de decomposição da austenita durante o resfriamento do aço após a austenitização. Como pode ser observado no diagrama de equilíbrio do sistema Fe-Mn (figura 1), a formação de ferrita em alta temperatura é suprimida por adições de $12-13 \% \mathrm{Mn}$, e o campo austenítico é expandido até teores de $50 \% \mathrm{Mn}$. Assim, as ligas metálicas com elevados teores de $\mathrm{Mn}(>12 \% \mathrm{Mn})$ possuem solidificação 
austenítica a partir de elevada temperatura (MARATRAY, 1995). Com o aumento do teor de Mn também ocorre a diminuição da temperatura liquidus, por exemplo, um aço com $30 \%$ de $\mathrm{Mn}$ tem a temperatura liquidus $\left(1400^{\circ} \mathrm{C}\right)$ aproximadamente $100^{\circ} \mathrm{C}$ mais baixa do que um aço com $10 \%$ de $\mathrm{Mn}\left(1500^{\circ} \mathrm{C}\right)$.

Figura 1 - Diagrama de equilíbrio do sistema Fe-Mn indicando o campo das fases líquido,

$\delta, \gamma+\alpha, \alpha, \alpha(\mathrm{Mn}), \gamma(\mathrm{Fe}, \mathrm{Mn}), \beta(\mathrm{Mn})$ e $\delta(\mathrm{Mn})$.

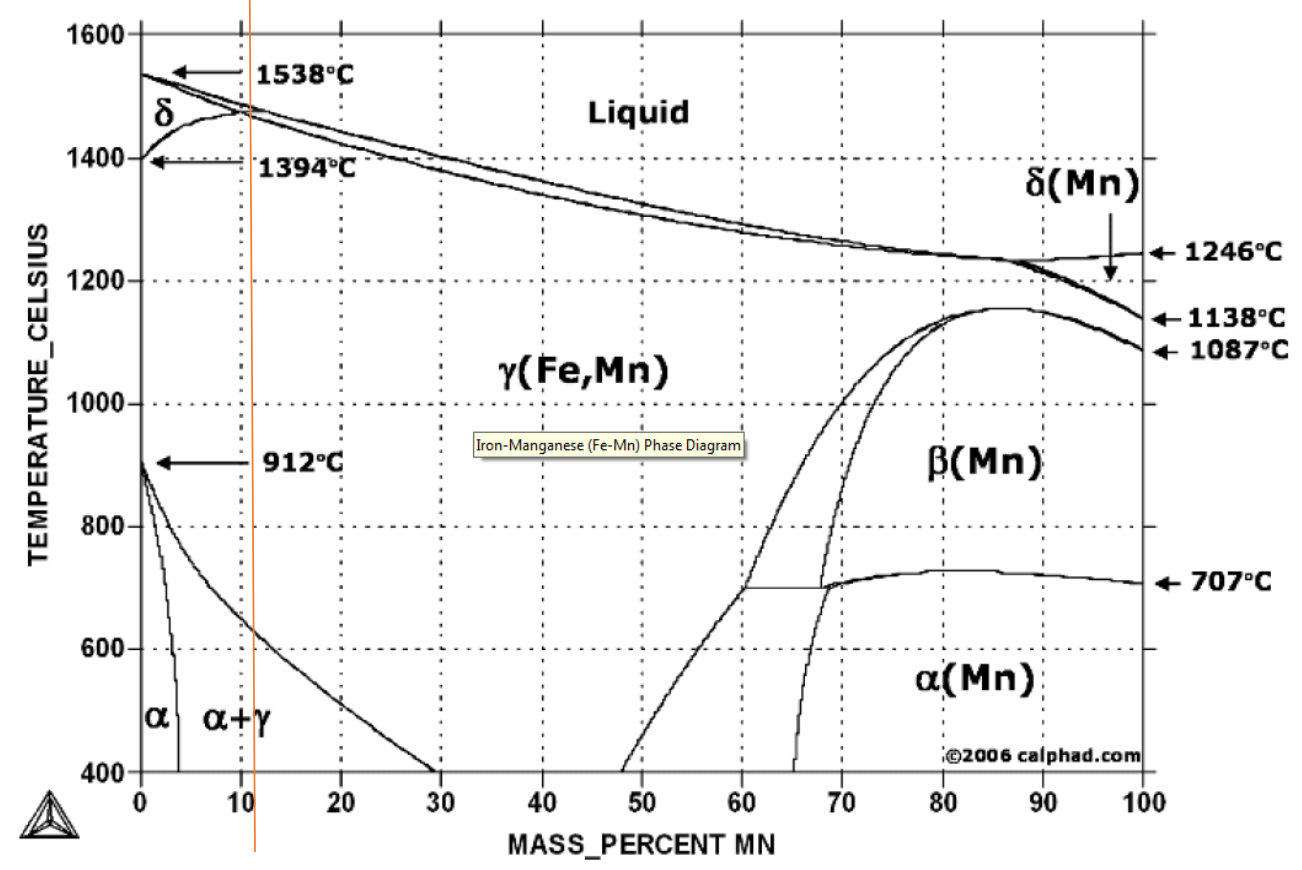

Fonte: Computational Thermodynamics Inc, 2011.

No diagrama de equilíbrio pseudo-binário Fe-C para o teor de $13 \%$ de $\mathrm{Mn}$ da figura 2 observa-se uma expansão do campo austenítico em relação ao diagrama binário $\mathrm{Fe}-\mathrm{C}$ convencional, isso ocorre devido à adição do manganês, que é um elemento estabilizador da fase austenita. O campo das fases $\mathrm{Fe}_{\alpha}+\gamma+\mathrm{M}_{3} \mathrm{C}$ também é expandido com o aumento do teor de Mn (figura 2) em comparação com o diagrama binário $\mathrm{Fe}-\mathrm{C}$ convencional. A extrapolação do diagrama binário até a temperatura ambiente indica, para baixos teores de $\mathrm{C}$ $(<0,1 \%)$, a presença de um campo binário composto pelas fases ferrita e austenita. Do mesmo modo, a extrapolação até a temperatura ambiente indica para teores mais elevados de $C$ (entre $0,1 \%$ e $1,1 \%$ ) a presença de um campo trifásico composto das fases austenita, ferrita e $\mathrm{M}_{3} \mathrm{C}$. Para teores de $\mathrm{C}$ maiores do que $1,1 \%$, a extrapolação indica a presença de um campo bifásico contendo 
ferrita e carboneto $\left(\mathrm{M}_{3} \mathrm{C}\right)$. Assim, a austenita com composição química entre 0,1 a $1,6 \%$ de $C$ resfriada rapidamente à temperatura ambiente é uma fase metaestável, que tende a se transformar nas condições de equilíbrio em ferrita e carbonetos em baixas temperaturas $\left(650^{\circ} \mathrm{C}\right.$ a $\left.625^{\circ} \mathrm{C}\right)$.

Figura 2 - Diagrama experimental pseudo-binário do aço Hadfield com $13 \% \mathrm{Mn}$, indicando o campo das fases $\gamma, \gamma+\mathrm{M}_{3} \mathrm{C}, \alpha+\gamma, \alpha+\gamma+\mathrm{M}_{3} \mathrm{C}$ e $\alpha+\mathrm{M}_{3} \mathrm{C}$.

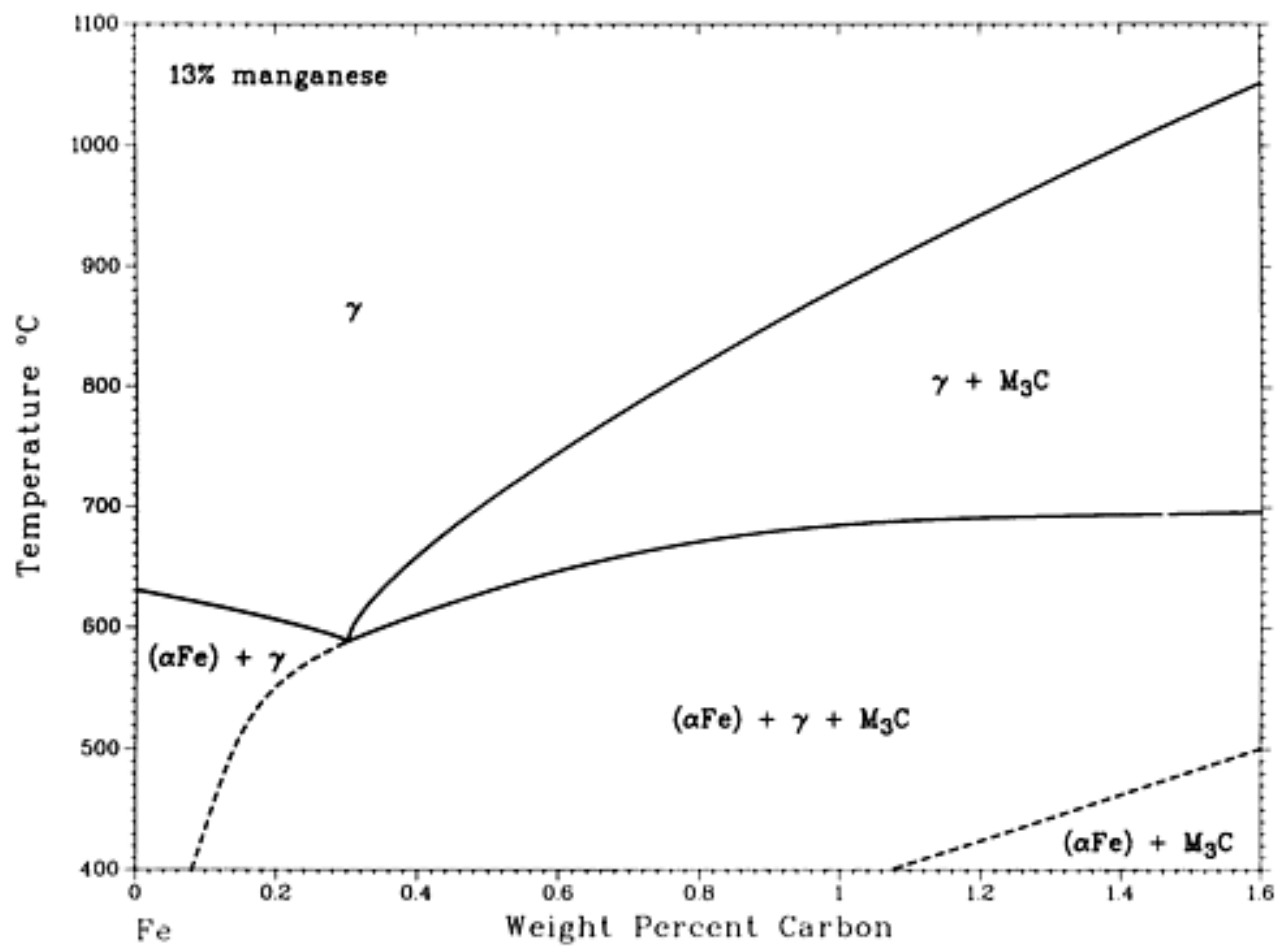

Fonte: ASM HANDBOOK v.15, 2004.

Benz et al (BENZ et al, 1973) determinaram as seções isotérmicas do sistema Fe-Mn-C na faixa de temperatura de $600-1100^{\circ} \mathrm{C}$ utilizando estudos termodinâmicos e metalúrgicos. Hillert (HILLERT, 1977) estudou as seções isotérmicas do sistema Fe-Mn-C na mesma faixa de temperatura utilizando o método CALPHAD, sendo que as propriedades termodinâmicas de equilíbrio como a energia livre de Gibbs para cada fase foi determinada analiticamente e os resultados estão de acordo com as informações experimentais obtidas por Benz et al (BENZ et al, 1973). Sil'man (SIL'MAN, 2005) calculou as seções isotérmicas do sistema $\mathrm{Fe}-\mathrm{Mn}-\mathrm{C}$ na faixa de temperatura de $400-1485^{\circ} \mathrm{C}$ usando os dados iniciais dos sistemas binários Fe-C, Fe-Mn, Mn-C e os valores do coeficiente de distribuição do $M n$ entre as fases $\left(M_{3} C, M_{7} C_{3}, \gamma, \alpha\right)$ em função 
da temperatura que foi determinado experimentalmente. No entanto, a descrição da metodologia é incompleta, já que não informa o software e banco de dados utilizados para a geração dos diagramas de fase.

As seções isotérmicas do diagrama ternário Fe-Mn-C a 1000,900 e $600^{\circ} \mathrm{C}$ (figura 3), obtidas por Benz et al (1973), mostram que o campo da fase austenítica é reduzido em baixas temperaturas, sendo substituído parcialmente pelas fases $\mathrm{Mn}-\beta$ e Mn- $\alpha$ á $900^{\circ} \mathrm{C}$ (figura 3-b) e por Fe- $\alpha$ à $600^{\circ} \mathrm{C}$ (figura 3-C) (RIVLIN, 1984). A solubilidade do carbono na fase austenita esta na faixa de $1,6-1,8 \%$ na temperatura de $1000^{\circ} \mathrm{C}$, sendo reduzida para $0,3 \%$ à $600^{\circ} \mathrm{C}$ (RIVLIN, 1984). Nas seções isotérmicas a 100, 900 e $600^{\circ} \mathrm{C}$ observa-se a formação dos carbonetos do tipo $\mathrm{M}_{23} \mathrm{C}_{6}, \mathrm{M}_{15} \mathrm{C}_{4}, \mathrm{M}_{3} \mathrm{C}, \mathrm{M}_{7} \mathrm{C}_{3}$, mostrando que existe um equilíbrio entre a fase austenítica e os carbonetos de manganês.

Figura 3 - Seções isotérmicas do sistema ternário Fe-Mn-C à (a) $1000^{\circ} \mathrm{C}$, (b) $900^{\circ} \mathrm{C} \mathrm{e} \mathrm{(c)} 600^{\circ} \mathrm{C}$ indicando os campos das fases $y-F e-, y-M n, \alpha-F e, \alpha-M n, M_{23} C_{6}, M_{15} C_{4}, M_{3} C$ e $M_{7} C_{3}$.

(a)

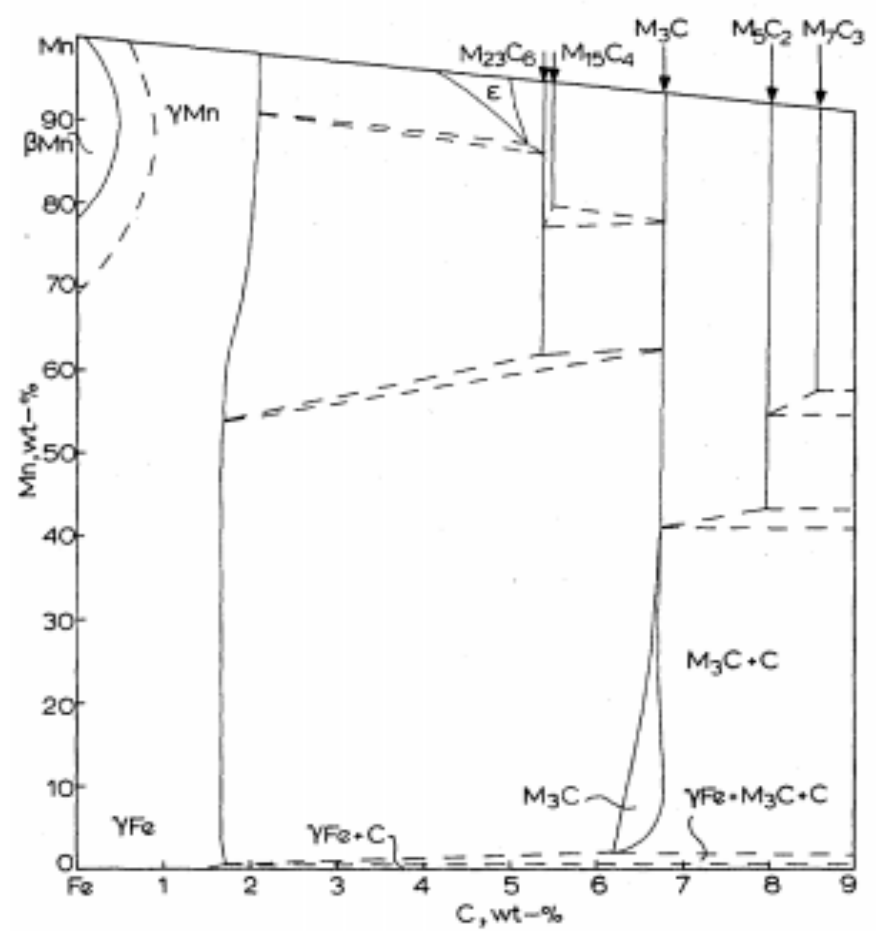


(b)

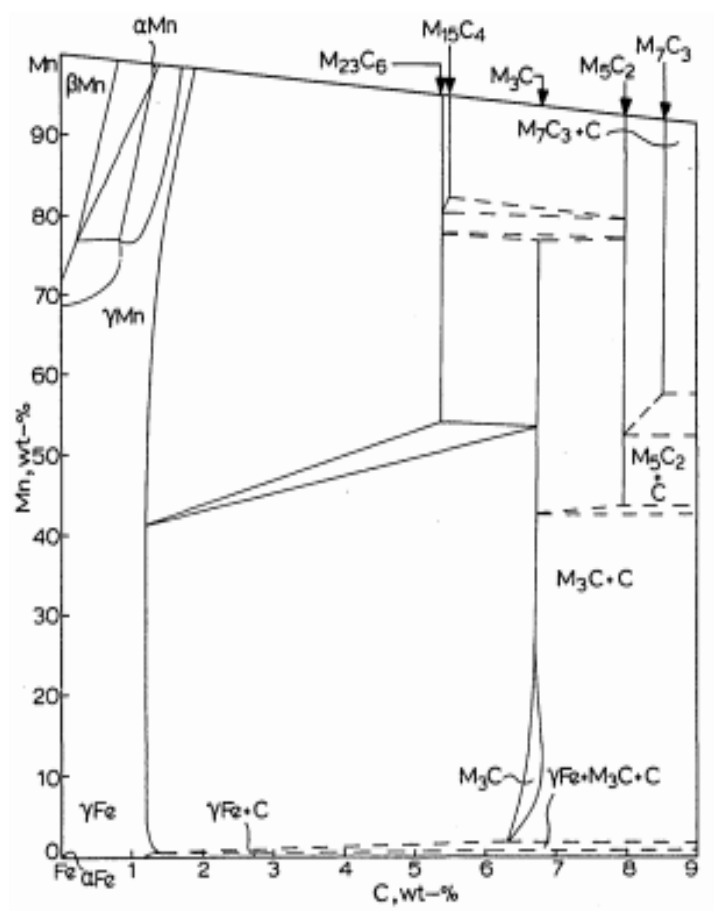

(c)

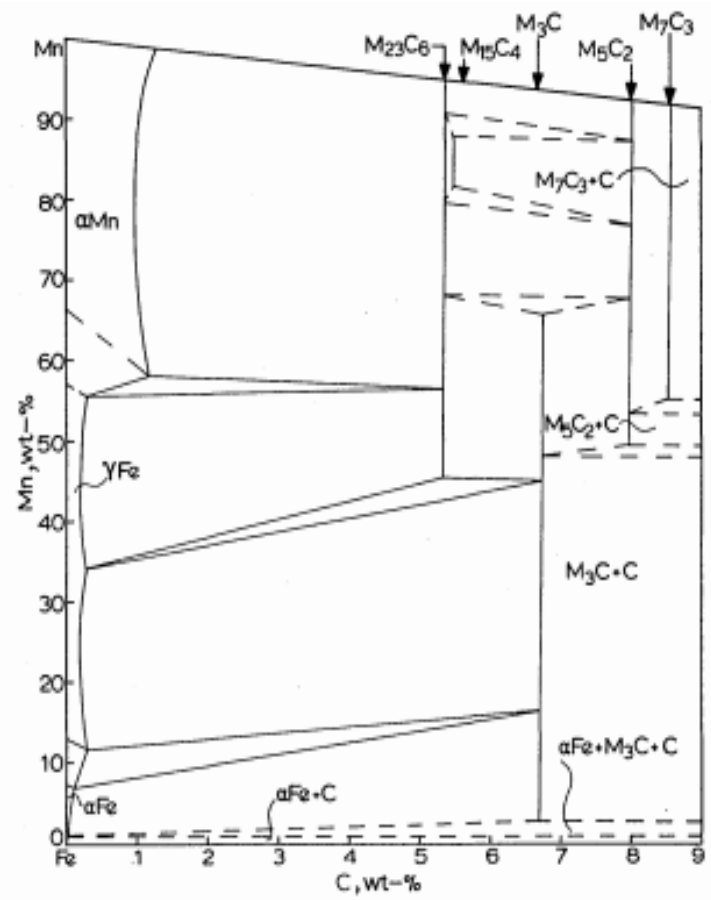

Fonte: Benz et al, 1973.

\subsubsection{Processamento do aço Hadfield}

Os componentes de aço Hadfield são produzidos em fornos elétricos, utilizando a prática básica de fusão, e também podem ser conformados mecanicamente pelo processo de laminação a quente (MARATRAY, 1995). O aço Hadfield possui baixa solubilidade ao oxigênio no estado líquido, porém a etapa de desoxidação, usualmente com Al/Si (é o principal desoxidante utilizado), $\mathrm{Ca} / \mathrm{Si}$ (para o controle das inclusões de alumina e sulfetos) e $\mathrm{Fe} / \mathrm{Si} / \mathrm{Zr}$ (para a fixação de $\mathrm{N}$ ) deve ser realizada no processo de fundição (FUOCO, 2007).

A temperatura liquidus do aço Hadfield com composição química de 1,4\% C e $14 \% \mathrm{Mn}$ é de $1380^{\circ} \mathrm{C}$, como indica a projeção da curva liquidus no diagrama ternário Fe-Mn-C (figura 4), sendo que na prática é utilizada temperatura de vazamento entre $1430-1450^{\circ} \mathrm{C}$ dependendo da composição química e espessura da peça (AVERY, 1961). A temperatura de vazamento e a taxa de solidificação são os principais parâmetros que influenciam no tamanho de grão do aço Hadfield no estado bruto de fundição (MARATRAY, 1995). O uso de 
altas temperaturas de vazamento resulta em elevado tamanho de grão e na segregação intergranular dos elementos $\mathrm{P}, \mathrm{Cr}$ e $\mathrm{C}$, que é prejudicial para a resistência mecânica, resistência à corrosão e ductilidade destes aços (TSUJIMOTO, 1979; KUYUCAK, 2001).

Figura 4 - Projeção da curva liquidus do diagrama ternário Fe-Mn-C.

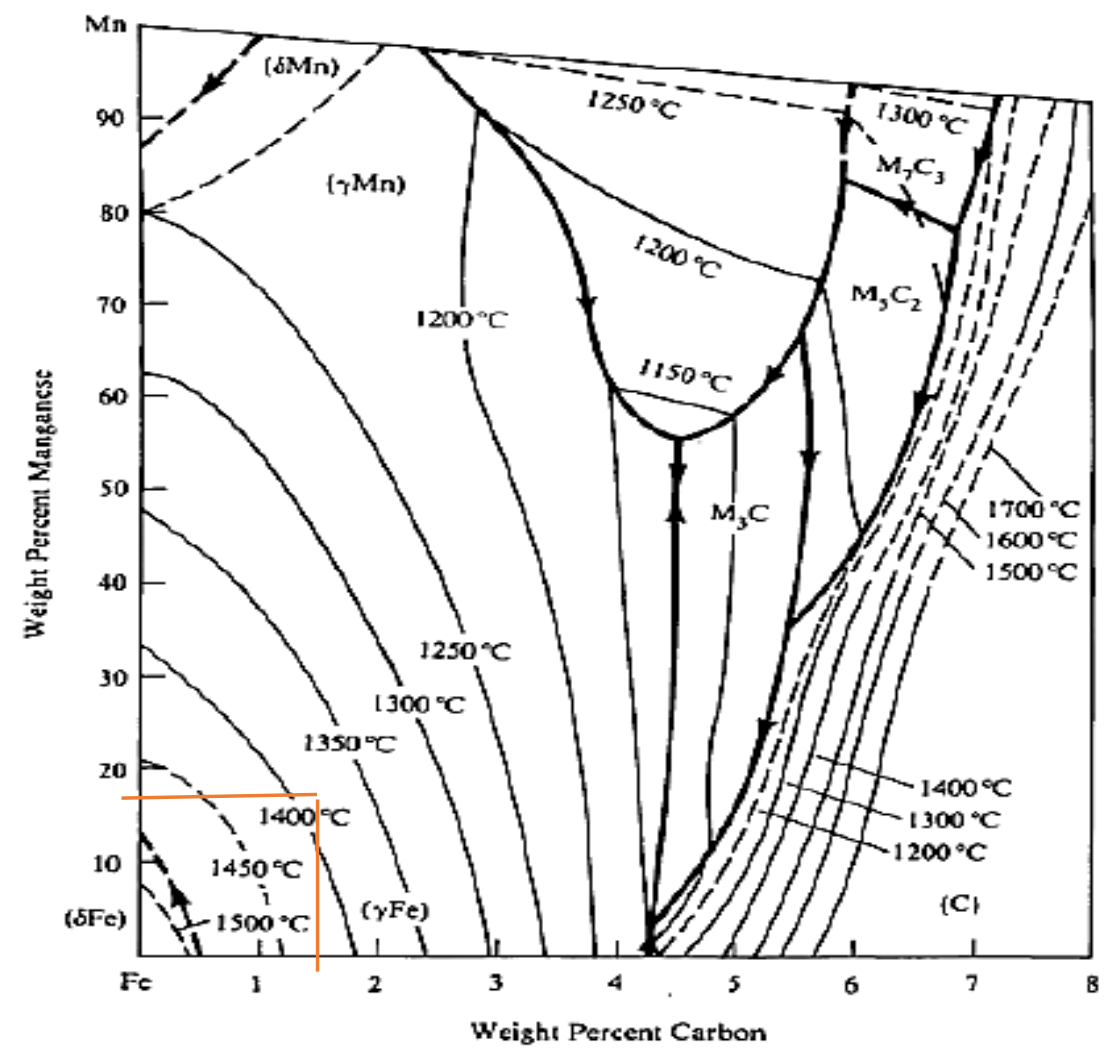

Fonte: Avery, 1961.

O aço Hadfield no estado bruto de fusão apresenta uma microestrutura austenítica metaestável com carbonetos eutéticos interdendríticos, carbonetos contínuos intergranulares e colônias de perlita (figura 5) como previsto para a solidificação do aço Hadfield com 1,2\% C e 14\% Mn segundo o diagrama de equilíbrio do sistema Fe-Mn-C (figura 2). Também podem ser formados carbonetos do tipo $\mathrm{M}_{23} \mathrm{C}_{6}, \mathrm{M}_{5} \mathrm{C}_{2}$ e $\mathrm{M}_{7} \mathrm{C}_{3}$ que não são indicados pela figura 4 , mas estão presentes no sistema Fe-Mn-C (HUANG, 1990). No sistema Fe-MnC também podem ser formadas a martensita a' que é CCC ou TCC dependendo do teor de $\mathrm{C}$ e a martensita $\varepsilon$ (HCP) como resultado de condições de resfriamento fora do equilíbrio a partir do estado totalmente austenítico (SCHUMANN, 1972). A martensita $\varepsilon$ pode ser formada a partir da austenita no 
aço Hadfield com teor de Mn menor do que $10 \%$ e $0,5 \%$ de C, e a martensita $\alpha$ no aço Hadfield com teores mais baixos de Mn e altos de C (SCHUMANN, 1972).

Figura 5 - Micrografia do aço Hadfield no estado bruto de fundição, indicando a matriz austenítica com a presença de carbonetos contínuos interdendríticos e perlita.

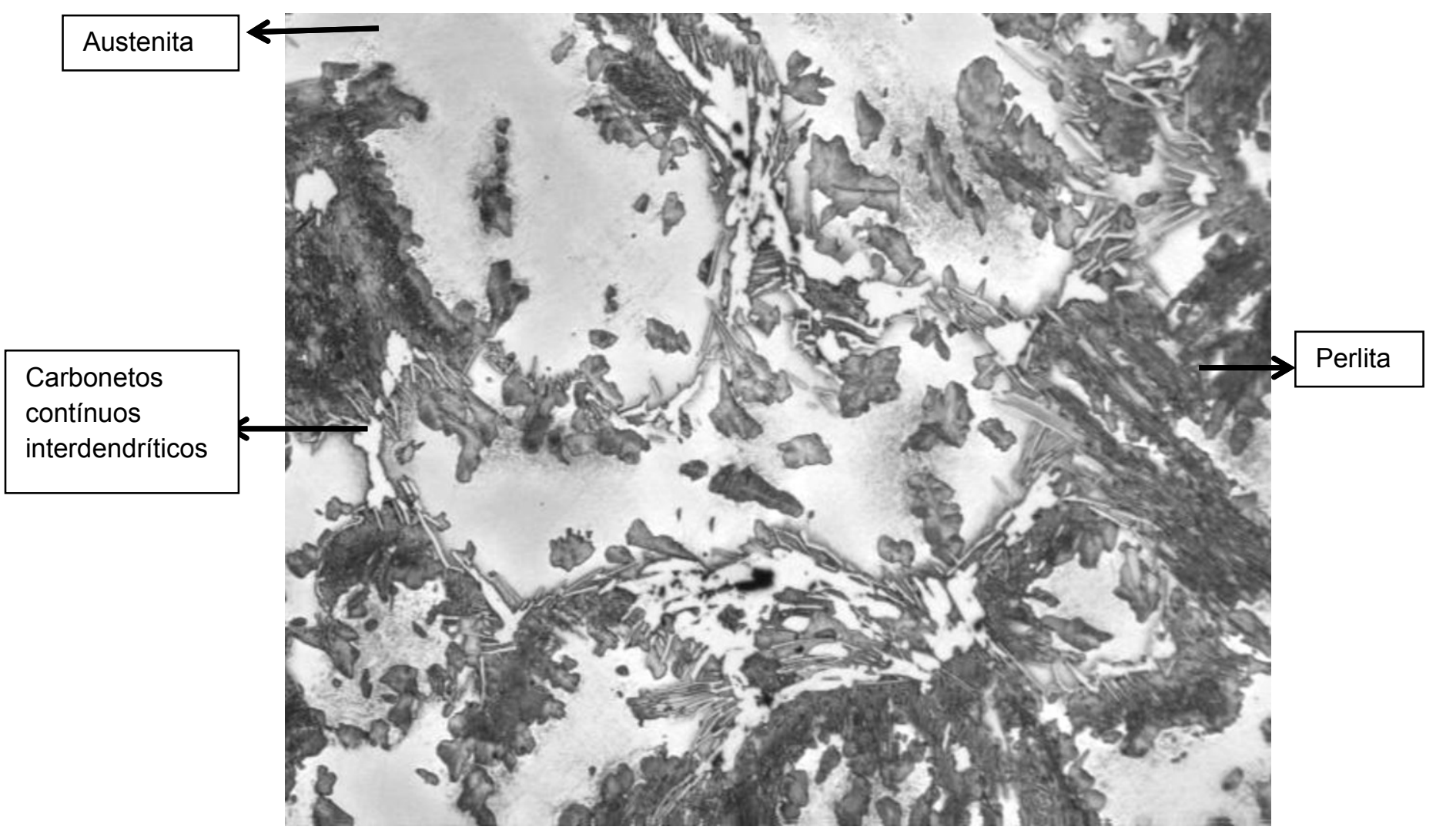

Fonte: Fuoco, 2007.

O aço Hadfield no estado bruto de fundição não apresenta as propriedades mecânicas de interesse para as aplicações em que é utilizado, sendo submetido ao tratamento térmico de solubilização para atingir a elevada energia absorvida no impacto $\left(110-180 \mathrm{~J} / \mathrm{cm}^{2}\right)$ que é característica deste aço (figura 6). O resfriamento lento em moldes de areia ou reaquecimento entre 400 e $800^{\circ} \mathrm{C}$ permite a formação de carbonetos interdendríticos ou intergranulares contínuos, que atuam como concentradores de tensão e fragilizam o material. A cinética de formação desses carbonetos segue uma curva em $C$ do diagrama de transformação isotérmica (figura 7), sendo que 0 crescimento é mais rápido entre $600-650^{\circ} \mathrm{C}$ (KUYUCAK, 2001). 
Figura 6 - Efeito de fragilização das precipitações de carbonetos eutéticos do tipo $M_{3} C$ em contornos de grãos na resistência ao impacto de aços Hadfield.

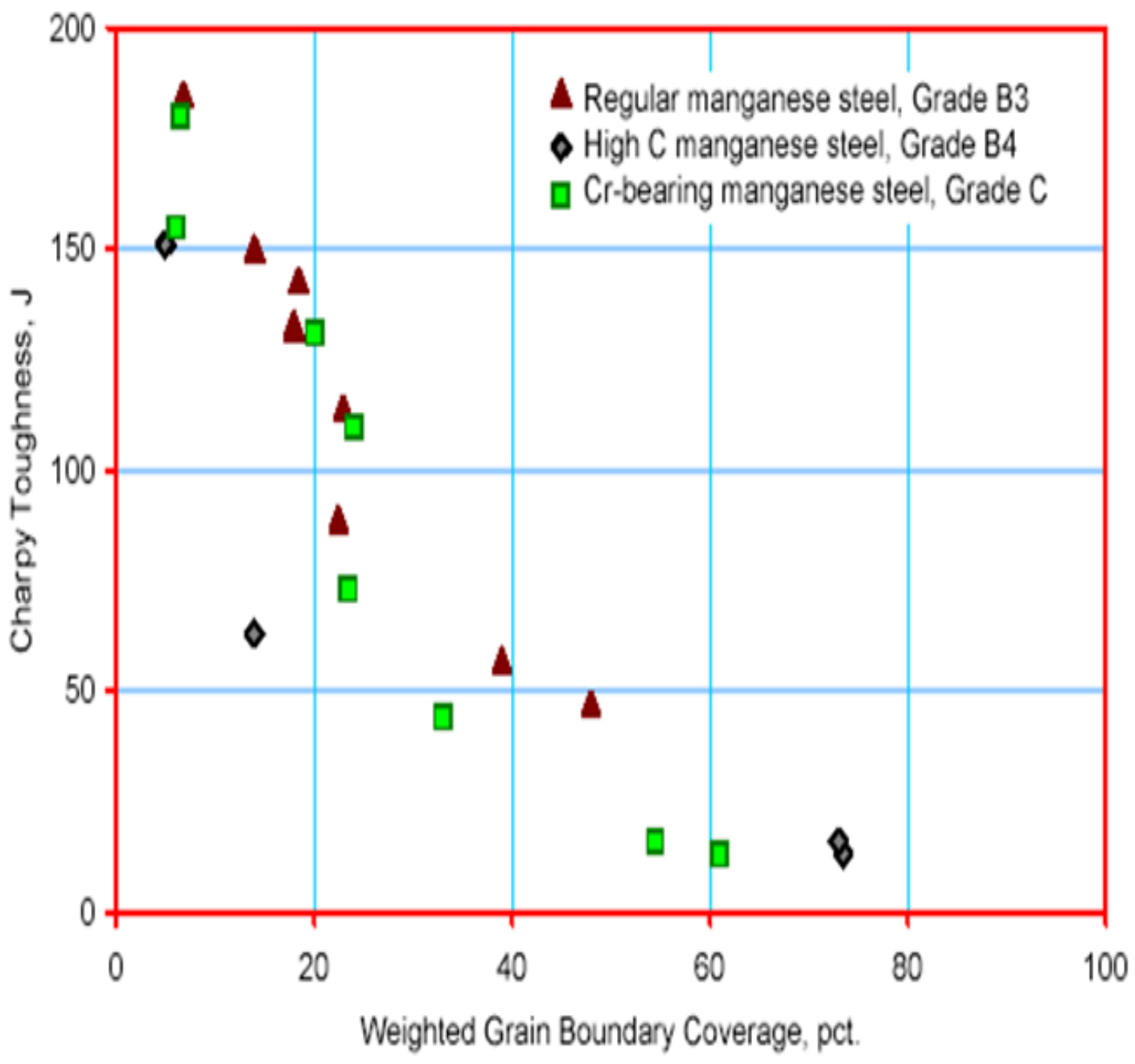

Fonte: Kuyucak, 2001. 
Figura 7 - Diagrama TTT de decomposição da austenita para o aço Hadfield com 13\% C.

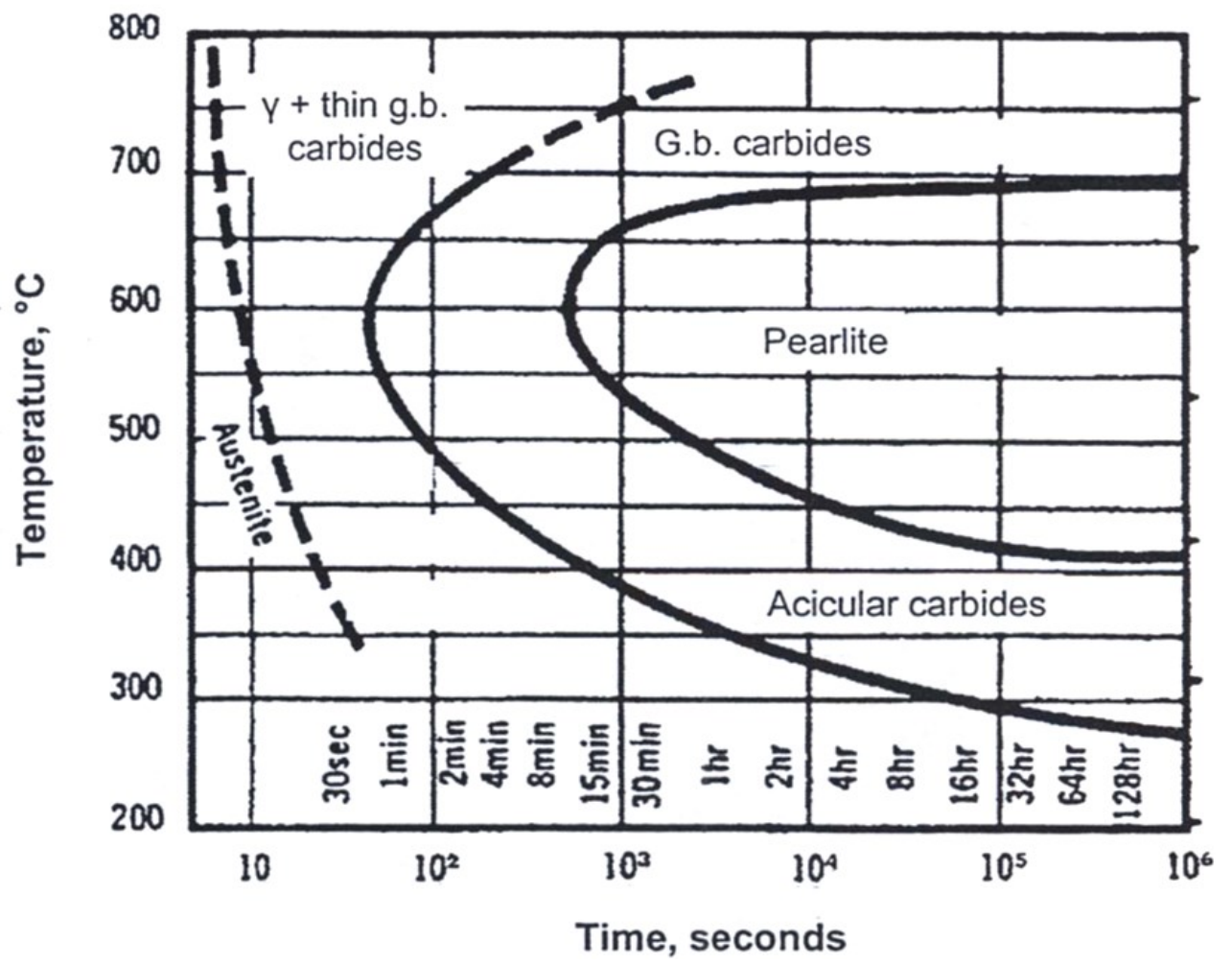

Fonte: Kuyucak, 2001.

O tratamento térmico de solubilização consiste em elevar a temperatura até a região de estabilidade da fase austenita, indicada pelo diagrama pseudobinário do aço Hadfield com 13\% de Mn (figura 8) (ASM HANDBOOK, 2004). Nessa temperatura, ocorrerá a dissolução dos carbonetos precipitados em contornos de grão e das colônias de perlita, mantendo o carbono e o manganês em solução sólida na austenita (MARATRAY,1995).

No aço Hadfield, o Mo está distribuído parcialmente como solução sólida na austenita e em carbonetos primários formados durante a solidificação, podendo ser utilizado em teores de $0,9-1,8 \%$ pois retarda a re-precipitação de carbonetos interdendríticos e perlita durante o resfriamento após o tratamento térmico de solubilização (FUOCO, 2012). Os tratamentos térmicos realizados em temperaturas acima de $1100^{\circ} \mathrm{C}$ ou tempos de manutenção durante o tratamento térmico acima de $2 \mathrm{~h}$ podem resultar em perdas no teor de carbono (descarbonetação). 
A adição de $\mathrm{Cr}$ que é utilizada para aumentar a resistência ao desgaste do aço Hadfield, tem efeitos negativos nas propriedades mecânicas do aço Hadfield após o tratamento térmico (KUYUCAK, 2001). O $\mathrm{Cr}$ facilita a reprecipitação de carbonetos de cromo nos contornos do grão austenítico durante o tratamento térmico de solubilização, reduzindo a energia absorvida no impacto do aço Hadfield (KUYUCAK, 2001).

Figura 8 - Diagrama pseudo-binário do aço Hadfield com 13\% Mn mostrando os campos das fases $\gamma, \gamma+M_{3} C, \gamma+\alpha, \gamma+\alpha+M_{3} C$ e $\alpha+M_{3} C$.

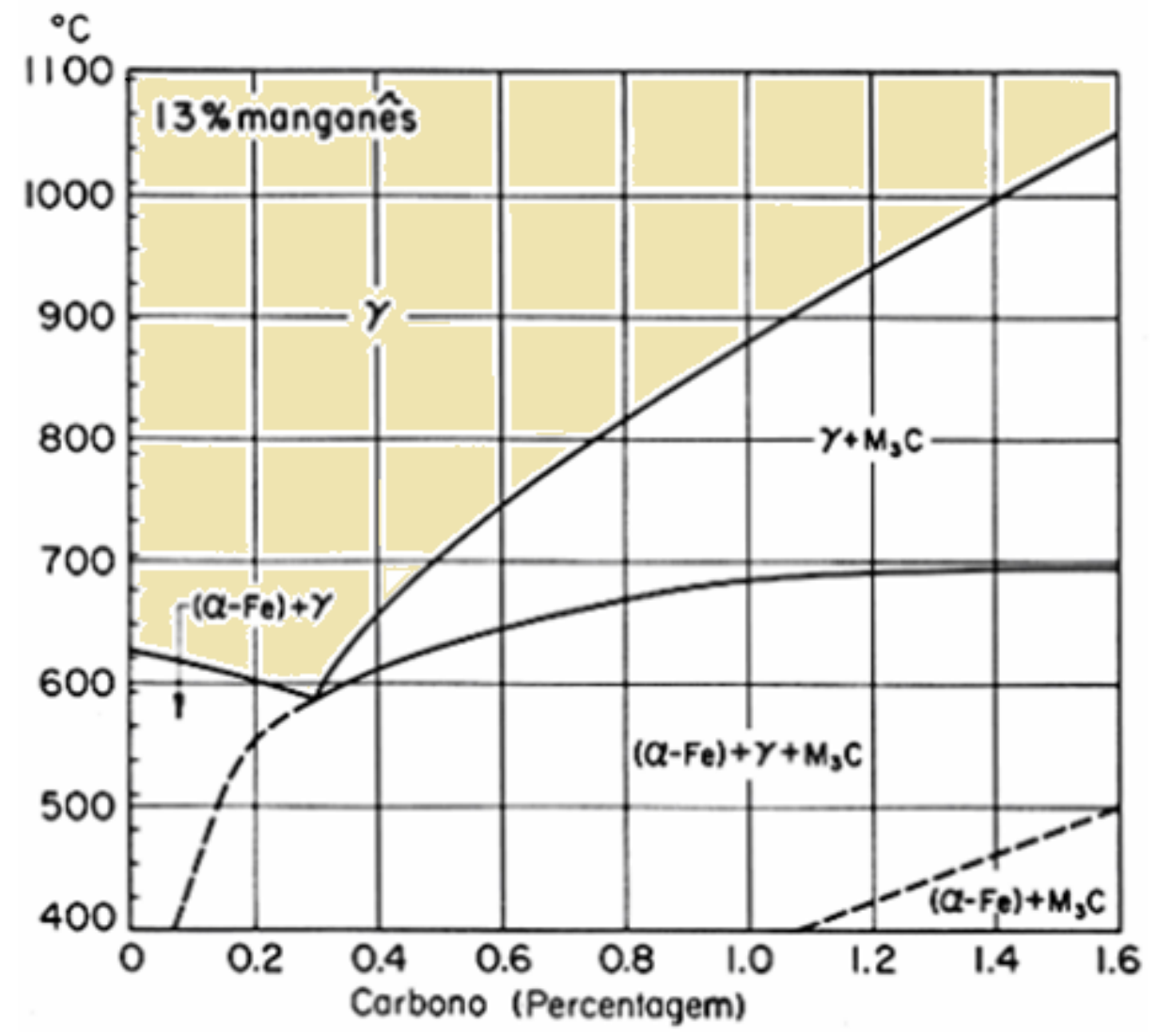

Fonte: Modificado de ASM Handbook, 2004.

Fuoco e Santos (2012) mostraram o efeito do $\mathrm{Cr}$, C e Mo na cinética de reprecipitação de carbonetos durante o resfriamento após o tratamento térmico de solubilização de um aço Hadfield com $12 \%$ de Mn. Foi observado que a adição de $2 \%$ de $\mathrm{Cr}$ reduziu para $50 \%$ o tempo para a reprecipitação de carbonetos interdendríticos, ou seja, o resfriamento após a solubilização deve ser $2 x$ mais rápido para os aços Hadfield com $\mathrm{Cr}(2 \%)$ em sua composição do 
que para os aços Hadfield sem $\mathrm{Cr}$. O carbono tem efeito semelhante ao $\mathrm{Cr}$ em relação ao tempo para a reprecipitação de carbonetos. Um aumento de 0,3\% no teor de $C$ provocou uma redução de $50 \%$ no tempo para a reprecipitação dos carbonetos. No entanto, a adição de $1 \%$ de Mo dobra o tempo para a formação de perlita durante o resfriamento após a solubilização. O Mo é utilizado na fundição de componentes que possuem seções espessas, ou seja, quando a taxa de resfriamento no interior da peça é menor do que a taxa de resfriamento na superfície. Nesses casos, o Mo aumenta o tempo em que o resfriamento após a solubilização pode ser realizado e aumenta a faixa de uso do carbono na composição química (FUOCO e SANTOS, 2012).

As principais causas das falhas que ocorrem em componentes de aço Hadfield estão relacionadas com deficiências nas etapas de fundição e realização do tratamento térmico das peças. $O$ aço Hadfield apresenta alimentação difícil, devido ao grande intervalo de solidificação, que acarreta na presença de micro porosidades em zonas quentes (BHERO et al, 2014). Durante o tratamento térmico de solubilização, as micro-trincas crescem como resultado dos processos de expansão e contração. $O$ aquecimento deve ser lento para evitar a nucleação de trincas internas, e a peça deve ser mantida na temperatura de austenitização por tempo suficiente para que ocorra a dissolução dos carbonetos formados durante a solidificação da peça fundida (BHERO et al, 2014).

Os problemas que podem ocorrer durante o tratamento térmico de solubilização dos carbonetos nos aços Hadfield são descritos a seguir:

(a) dissolução incompleta dos carbonetos: a temperatura de realização do tratamento térmico deve ser elevada o suficiente para que a matriz consiga dissolver os carbonetos contínuos, que são os principais responsáveis pela perda de tenacidade à fratura (KUYUCAK, 2003);

(b) reprecipitação de carbonetos: a taxa de resfriamento após o patamar do tratamento térmico deve ser alta, para que os carbonetos já dissolvidos na matriz não precipitem novamente, conforme mostrado no diagrama TTT de decomposição da austenita (figura 9) no aço Hadfield com 13\% de Mn (HAM et al, 2010); 
(c) fusão no contorno de grão: pode ocorrer fusão de precipitados eutéticos intergranulares ricos em $\mathrm{P}$ devido ao seu baixo ponto de fusão (KUYUCAK, 2003). Esse é um dos motivos do teor de $P$ ser mantido baixo $(0,07 \%$ no máximo) na composição química do aço Hadfield.

Existem variações do tratamento térmico de solubilização que podem ser utilizadas para aumentar as propriedades mecânicas como o limite de escoamento e a resistência à abrasão. Em aços austeníticos do grau E-2 da ASTM A128, que possuem $2 \%$ de Mo, é utilizado um tratamento térmico para desenvolver uma microestrutura de carbonetos interdendríticos finamente dispersos na austenita (SUBRAMANYAM, SWANSIGER, AVERY, 1961). O tratamento térmico consiste na redução do tamanho de grão pela perlitização à $595^{\circ} \mathrm{C}$ por $12 \mathrm{~h}$ seguido de têmpera em água à $980^{\circ} \mathrm{C}$ (figura 9 ). $\mathrm{O}$ limite de escoamento aumentou de 440 para $480 \mathrm{MPa}$, a resistência à tração de 695 para $850 \mathrm{MPa}$, e o alongamento de 15 para 25\% (SUBRAMANYAM, SWANSIGER, AVERY, 1961). O alongamento desse material é baixo em relação aos aços austeníticos, que possuem alongamento em torno de $40 \%$ (SUBRAMANYAM, SWANSIGER, AVERY, 1961). No entanto, os autores não estudaram os efeitos da realização deste tratamento térmico na energia absorvida no impacto do aço Hadfield.

Figura 9 - Tratamento térmico de perlitização do aço ao manganês austenítico

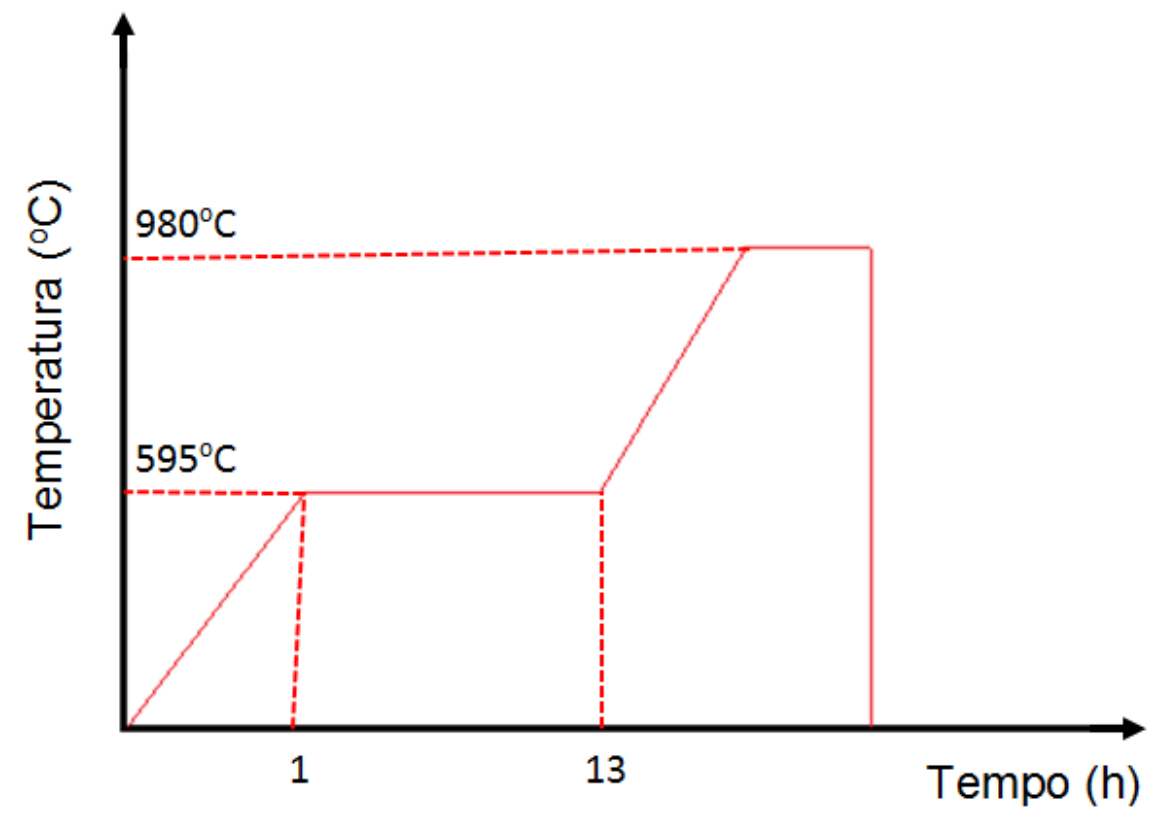


Ham et al (2010) determinaram a taxa de resfriamento crítico para evitar a reprecipitação de carbonetos interdendríticos durante a solubilização por meio de microscopia óptica e o método dos elementos finitos (MEF). Observaram que o ponto crítico para a precipitação de carbonetos ocorre a 4,5 $\mathrm{cm}$ de profundidade na amostra (150 mm x $150 \mathrm{~mm} \times 250 \mathrm{~mm}$, cúbica), porém isso depende da composição química e condições de resfriamento da peça. A amostra de estudo possui composição química de 1,2\% C, 13\% Mn, 0,6\% Si e $1,8 \% \mathrm{Cr}$, e o resfriamento da peça foi realizado em água sem agitação. A taxa de resfriamento crítica obtida por análise numérica é de $3^{\circ} \mathrm{C} / \mathrm{s}$, e está de acordo com a taxa de resfriamento obtida experimentalmente, e corresponde à região de $4,5 \mathrm{~cm}$ de profundidade na peça. Os resultados mostraram que o método dos elementos finitos foi eficaz para a determinação da taxa de resfriamento crítico durante a solubilização de aços Hadfield.

Hosseini et al (2011) estudaram o uso de uma solução de $\mathrm{NaCl}(1,5 \%$ a $3 \%$ ), em substituição à água pura, na etapa de têmpera do tratamento térmico de solubilização do aço Hadfield. A solução de $\mathrm{NaCl}$ promove uma maior taxa de resfriamento do aço Hadfield do que a água pura, evitando a reprecipitação dos carbonetos em contornos de grão que reduzem a tenacidade desses materiais. A energia ao impacto Chapy aumentou de $25 \mathrm{~J} / \mathrm{cm}^{2}$ para $59 \mathrm{~J} / \mathrm{cm}^{2}$ quando uma solução de $3 \% \mathrm{NaCl}$ foi utilizada para a têmpera do aço Hadfield. No entanto, os valores de energia ao impacto determinados neste trabalho são inferiores aos especificados para este material (110-180 J/cm²). A composição química do aço Hadfield utilizado apresenta elevados teores de $C(1,3 \%)$ e $\mathrm{Cr}$ $(1,9 \%)$, sugerindo que o tratamento térmico utilizado não foi eficiente para a solubilização dos carbonetos interdendríticos que reduzem a energia absorvida no ensaio de impacto Charpy.

\subsubsection{Propriedades mecânicas do aço Hadfield}

O aço Hadfield apresenta propriedades de desgaste como resistência á abrasão baixa se comparada aos demais materiais que são utilizados para aplicações na indústria de mineração, como ferro fundido branco de alto cromo, aços de baixa liga martensíticos e aços perlíticos com elevado teor de carbono 
(AGUNSOYE et al, 2012; FUOCO, 2012). A figura 10 mostra a curva de tensão - deformação característica do aço Hadfield em comparação com o ferro fundido cinzento e aços ao carbono (ALYAZ, 2003). Observa-se que o aço Hadfield possui maior deformação antes da fratura e elevada resistência à fratura, além disso, possui elevada tenacidade, com energia absorvida em torno de $169 \mathrm{~J} / \mathrm{cm}^{2}$ no ensaio de impacto Charpy, o que diferencia o aço Hadfield dos demais materiais citados.

Figura 10 - Curva de tensão-deformação verdadeira característica do aço Hadfield em comparação com o ferro fundido cinzento e aços ao carbono.

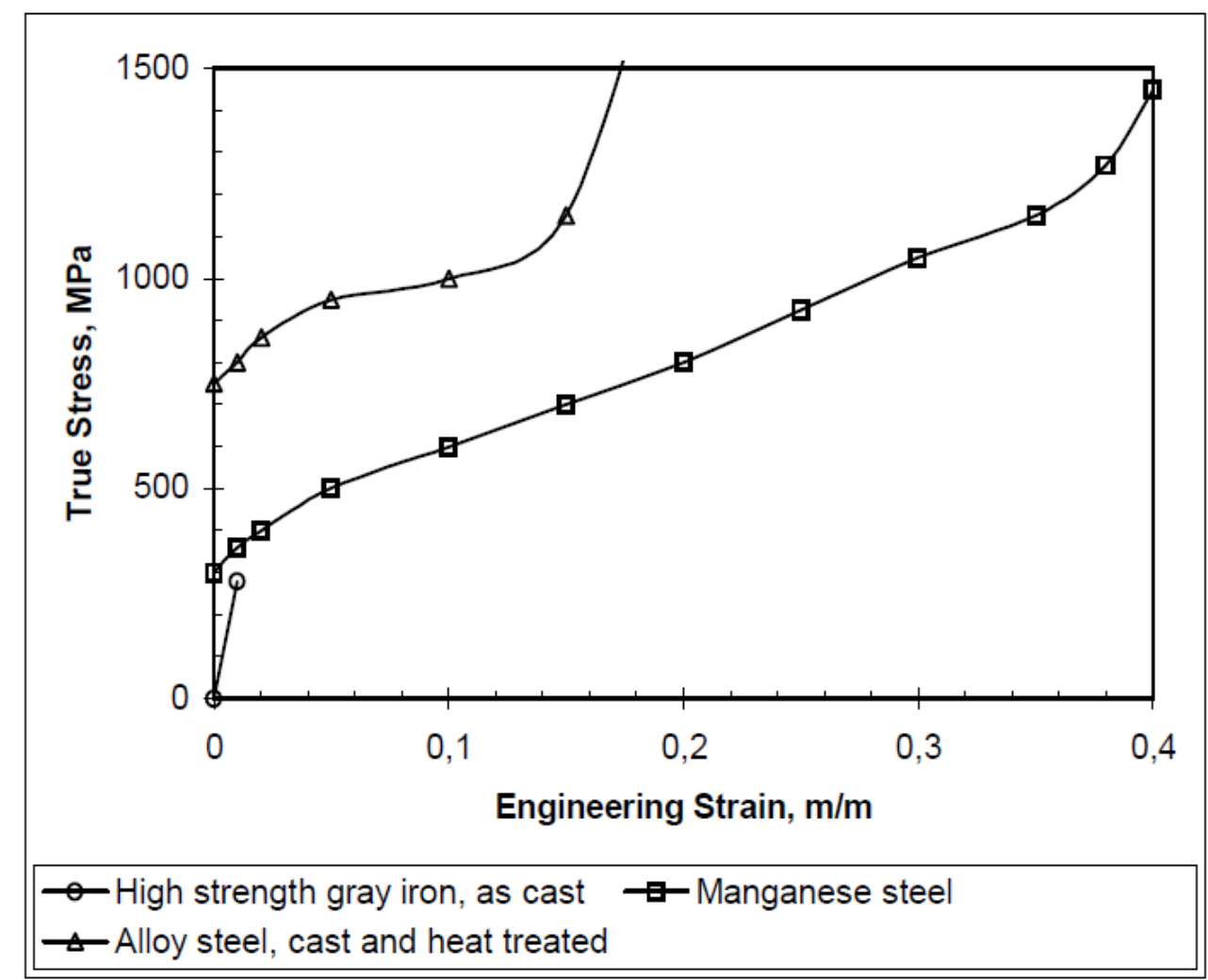

Fonte: Aliaz, 2003.

As propriedades mecânicas típicas do aço Hadfield estão descritas na tabela 2. Observa-se que o limite de escoamento é baixo (320 - $360 \mathrm{MPa}$ ), porém possui elevado alongamento $(40 \%)$ e resistência à tração $(700-1000$ $\mathrm{MPa}$ ). A dureza do aço Hadfield é de aproximadamente $220 \mathrm{HB}$ após o tratamento térmico, mas este valor não é significativo para estimar a usinabilidade ou resistência ao desgaste. Durante a usinagem ou em serviço, a 
dureza aumenta devido à elevada taxa de encruamento do aço Hadfield (TSUJIMOTO, 1979). A distribuição de dureza não é homogênea, principalmente pelas diferentes orientações cristalográficas dos grãos austeníticos, e a distribuição das subestruturas de deformação (discordâncias e maclas de deformação).

Tabela 2 - Propriedades mecânicas do aço Hadfield (13\% Mn).

\begin{tabular}{|c|c|c|c|c|c|}
\hline $\begin{array}{c}\text { Limite de } \\
\text { escoamento } \\
\text { (MPa) }\end{array}$ & $\begin{array}{c}\text { Resistência à } \\
\text { tração } \\
(\mathbf{M P a})\end{array}$ & $\begin{array}{c}\text { Redução } \\
\text { de área } \\
\mathbf{( \% )}\end{array}$ & $\begin{array}{c}\text { Módulo } \\
\text { de Young } \\
\text { (GPa) }\end{array}$ & $\begin{array}{c}\text { Dureza } \\
\text { Brinell }\end{array}$ & $\begin{array}{c}\text { Energia } \\
\text { absorvida no } \\
\text { impacto }\end{array}$ \\
\hline $320-360$ & $700-1000$ & $30-40$ & 186 & $185-220$ & $110-180$ \\
\hline
\end{tabular}

Fonte: Modificado de Avery, 1949; Subramanyam, Swansiger, Avery, 1990; Oguiza, 2012.

O aço Hadfield possui baixa dureza superficial (200 HB), porém apresenta alta taxa de encruamento em serviço, o que eleva sua dureza superficial mantendo a camada interna tenaz (AVERY, 1974). A máxima dureza possível depende da composição química, limitações de serviço, método de encruamento ou de trabalho e procedimentos de proteção e pré-serviço.

As propriedades mecânicas do aço Hadfield também são influenciadas pela composição química. A ductilidade e resistência à tração do aço Hadfield dependem do teor de $\mathrm{C}$ e $\mathrm{Mn}$ presentes. Conforme a figura 11, teores ideais para a manutenção da ductilidade do aço são de 0,8-1,25\%, já que o $C$ favorece a precipitação de carbonetos contínuos no contorno do grão austenítico (KUYUCAK; ZAVADIL; NEWCOMBE, 2001; ALYAZ, 2003). Além disso, o $C$ aumenta a resistência à tração até $1,3 \%$ e o Mn até teores de $14 \%$, não tendo efeito significativo no limite de escoamento (SUBRAMANYAM; SWANSIGER; AVERY, 1990). Já o Cr é utilizado para aumentar o limite de escoamento, dureza e resistência ao desgaste do aço Hadfield. Machado (2017) estudou o efeito do teor de Mn (12 e 20\%) na resistência ao desgaste do aço Hadfield através de ensaios de britador de mandíbula. $O$ autor mostrou que o aço Hadfield com $20 \%$ de Mn possui tendência de apresentar maior resistência ao desgaste do que o aço Hadfield com $12 \%$ de Mn, considerando- 
se os resultados obtidos pela mandíbula fixa que possui maior severidade de desgaste do que a mandíbula móvel (MACHADO, 2017).

Figura 11 - Efeito do teor de C nas propriedades mecânicas do aço Hadfield. (a) Efeito do teor de $\mathrm{C}$ na resistência à tração (MPa) e no limite de escoamento (MPa); (b) Efeito do teor de $\mathrm{C}$ no alongamento (\%).

(a)
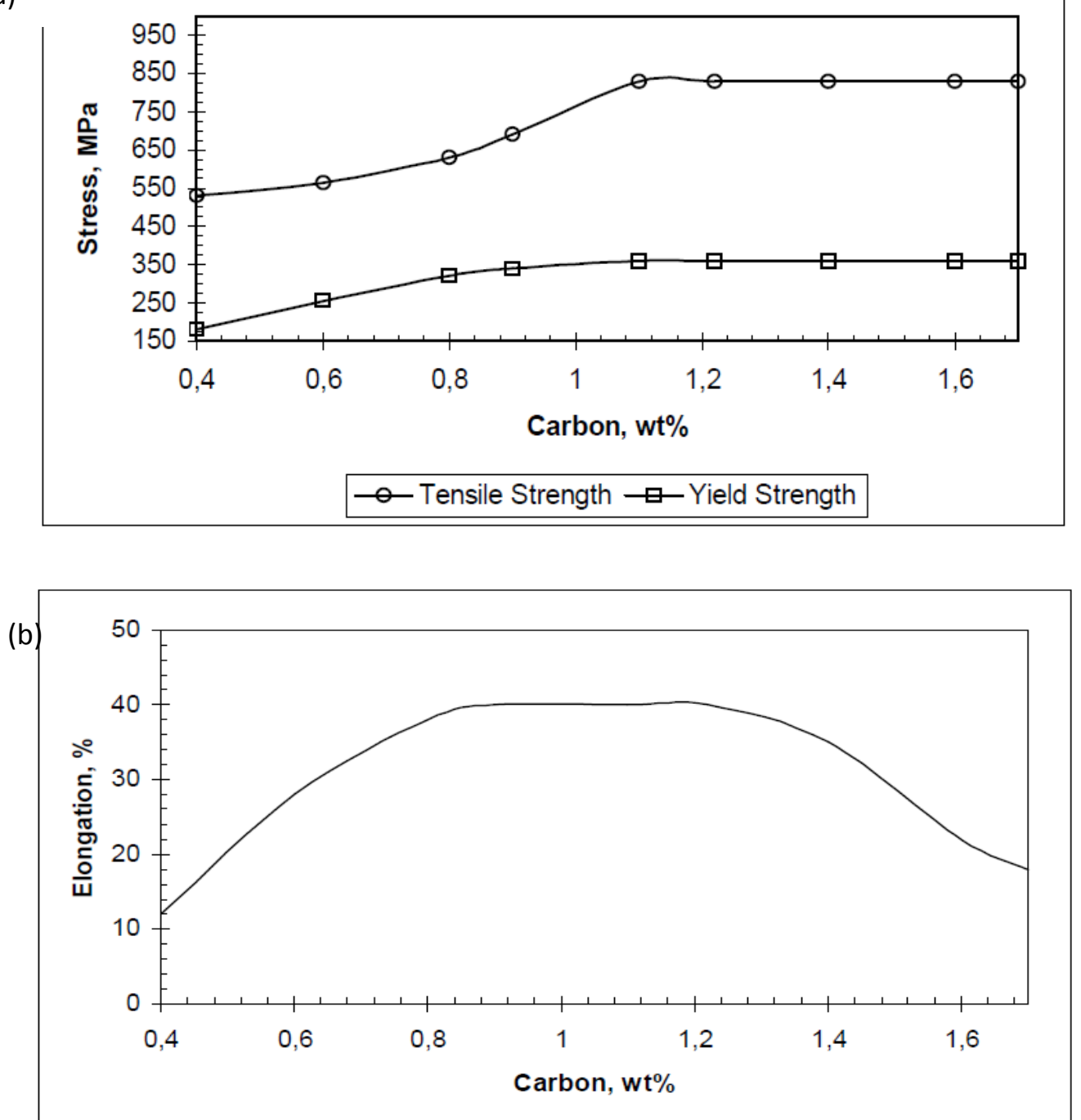

Fonte: Alyaz, 2003.

Rotondaro (1978) estudou o efeito do teor de $\operatorname{Cr}(0,2$ - 2,85 \%) no encruamento do aço ao manganês austenítico através de ensaios de tração, compressão e caracterização microestrutural de amostras retiradas de 
britadores de mandíbula gastos. Os resultados dos ensaios de tração e compressão apresentados por Rotondaro (1978) mostraram que o teor de $\mathrm{Cr}$ não teve influencia significativa na capacidade de encruamento do aço Hadfield, mas as amostras com 2,85\% de $\mathrm{Cr}$ apresentaram maior dureza inicial em comparação com as amostras sem $\mathrm{Cr}$ (endurecimento por solução sólida). Observou-se também que o efeito do teor de $C(1,04 \%$ para $0,2 \%)$ é maior do que o efeito do aumento do teor de $\mathrm{Cr}$ na capacidade de encruamento do aço Hadfield, considerando-se as deformações com altas velocidades (ROTONDARO, 1978).

O Mn tem influência na energia de falha de empilhamento (EFE) do aço, que está relacionada com os mecanismos de deformação plástica e as propriedades mecânicas. Durante a deformação plástica do aço pode ocorrer a formação de maclas mecânicas, transformação martensítica ou deslizamento de discordâncias dependendo do valor da EFE (DASTUR; LESLIE, 1981 199GIRALDO, 2012). O Mn diminui a EFE da austenita, aumentando a distância entre as discordâncias parciais, dificultando o escorregamento cruzado (cross-slip) das discordâncias e diminuindo a energia de ativação para a formação de maclas mecânicas durante a deformação plástica. A energia de falha de empilhamento do aço Hadfield com 1,2\% e e 13\%Mn esta na faixa de 20-40 $\mathrm{mJ} / \mathrm{m}^{2}$, que é um valor ligeiramente elevado em comparação com outros metais CFC como a $\mathrm{Ag}\left(16 \mathrm{~mJ} / \mathrm{m}^{2}\right)$ e aços inoxidáveis austeníticos $\left(20 \mathrm{~mJ} / \mathrm{m}^{2}\right)$ (XIONG et al, 2015).

A alta taxa de encruamento do aço Hadfield em serviço ainda não é completamente compreendida. Inicialmente, foi proposto que o endurecimento era resultado de uma transformação induzida por deformação da austenita em martensita a e $\varepsilon$, porém é demonstrado que a composição da austenita é estável durante a deformação plástica até temperaturas abaixo de $-196^{\circ} \mathrm{C}$ (DASTUR; LESLIE, 1981; GIRALDO, 2012). A transformação induzida por deformação somente ocorre em regiões locais de instabilidade da austenita devido à descarbonetação e segregação dos elementos de liga $(C, M n)$. Estudos recentes mostram que os mecanismos responsáveis pela alta taxa de endurecimento por deformação dos aços Hadfield são a interação entre átomos de carbono intersticiais e discordâncias, a interação entre discordâncias e 
maclas, e a interação entre os sistemas de maclação (ADLER ET AL, 1986; BAYRAKTAR, 1993; YELEUSSIZOVA ET AL, 2013).

\subsection{DEFORMAÇÃO PLÁSTICA POR MACLAÇÃO}

A deformação por maclação têm sido extensivamente estudada devido às propriedades de elevada ductilidade e taxa de encruamento que alguns materiais apresentam, como por exemplo, o aço TWIP (twinning-induced plasticity steel) (KIM ET AL, 2017) que deforma por maclação. A maclação também é observada em ligas de $\mathrm{Ti}$ e $\mathrm{Mg}, \mathrm{Al}, \mathrm{Zn}, \mathrm{Zr}$, aços austeníticos, e metais em condições de alta taxa de deformação e/ou baixa temperatura. $A$ deformação por maclação ocorre preferencialmente quando o metal apresenta poucos sistemas de escorregamentos disponíveis, como é o caso das estruturas cristalinas do tipo $\mathrm{HC}$ ou monoclínica, e de cristais com baixa simetria (CAHN E HAASEN, 1996).

Em metais que se deformam por maclação, com a aplicação de uma tensão de cisalhamento, uma parte dos átomos da rede são deformados de modo que formam uma imagem em espelho dos átomos ao seu redor que não sofreram a deformação. $O$ plano cristalográfico de simetria entre a porção deformada e não deformada é chamado de plano da macla (ABBASCHIAN, REED-HILL, 1964). A maclação ocorre em um plano cristalográfico e em uma direção cristalográfica específicos, assim como o escorregamento. O conjunto de plano e direção em que ocorrerá a maclação dependerá do tipo de estrutura cristalina (SMALLMAM E BISHOP, 2014). Na tabela 3 têm-se os planos e direção preferenciais para a maclação nas estruturas cristalinas CCC, CFC e $\mathrm{HC}$. 
Tabela 3- Plano e direção cristalográfica preferencial para a maclação nas estruturas cristalinas do tipo CFC, CCC e HC.

\begin{tabular}{|c|c|c|}
\hline Estrutura cristalina & Plano cristalográfico & Direção Cristalográfica \\
\hline CFC & $(111)$ & {$[112]$} \\
\hline CCC & $(112)$ & {$[111]$} \\
\hline HC & $(10 \overline{1} 2)$ & {$[10 \overline{1} \overline{1}]$} \\
\hline
\end{tabular}

Fonte: Smallmam e Bishop, 2014.

$\mathrm{Na}$ deformação por escorregamento, não existem alterações na estrutura cristalina e na orientação cristalográfica antes e após a deformação, além disso, a deformação ocorre em planos individuais da rede, como pode ser visto na figura 12-a (ABBASCHIAN, REED-HILL, 1964). O cisalhamento associado com a deformação por maclação é distribuído de modo uniforme ao longo de um volume de átomos, vide figura 12-b. Neste caso, os átomos movimentam-se somente uma fração do espaçamento interatômico (figura 12b). Na maclação, ocorre a reorientação dos átomos acima e abaixo do plano da macla. Na figura 13-a, tem-se uma representação dos átomos de uma estrutura cristalina antes da deformação (ABBASCHIAN, REED-HILL, 1964). Na figura 13-b, temos o cristal após a aplicação de uma deformação de cisalhamento em que a maclação é induzida. Na figura 13-b, observa-se que o deslocamento dos átomos deformados é pequeno em relação aos seus átomos vizinhos. 
Figura 12 - Representação esquemática da deformação por escorregamento (a) em comparação com a maclação (b) em metais com estrutura cubica de face centrada (CFC)

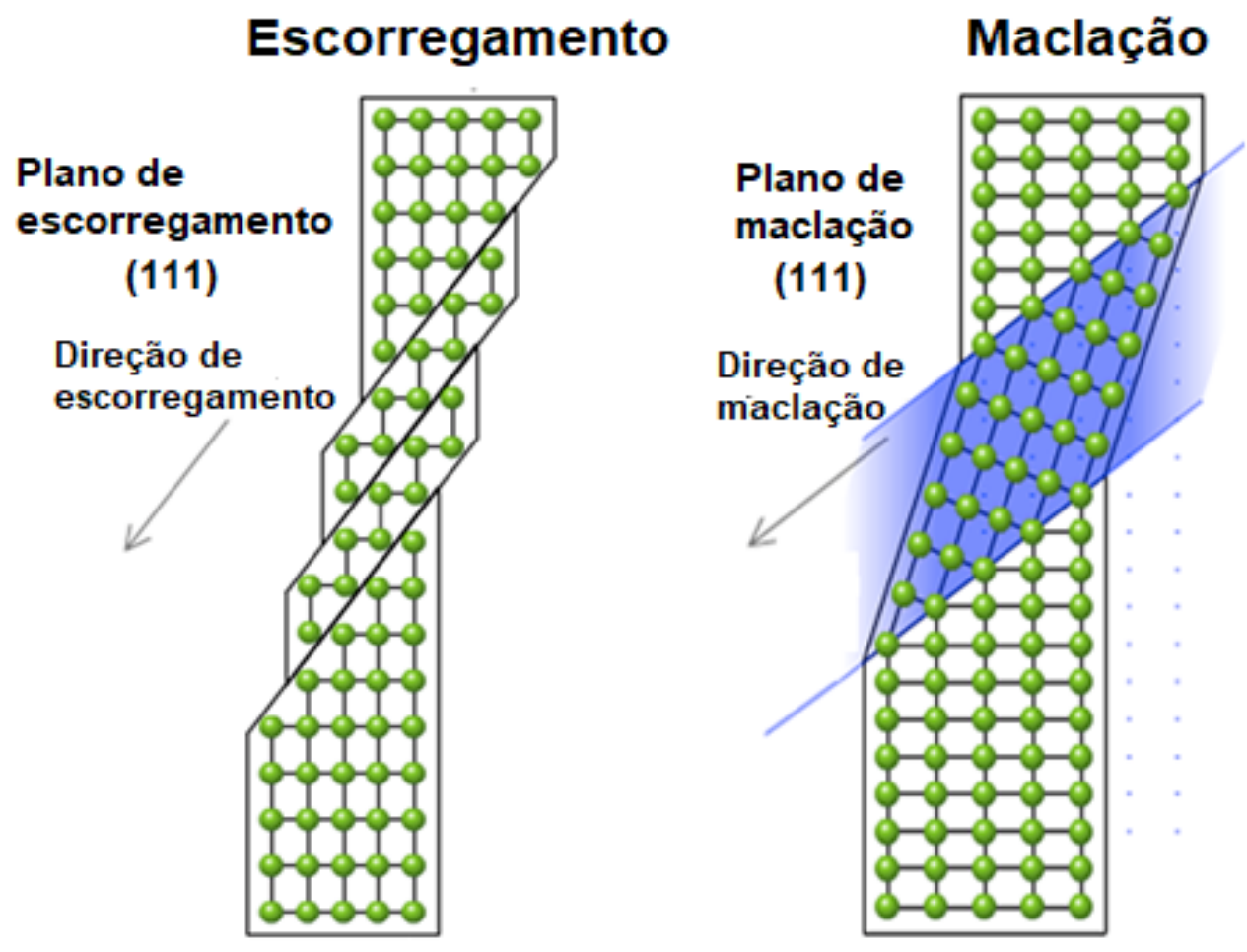

Fonte: Modificado de DoiTPoMS / University of Cambridge, 2017.

Figura 13 - Representação esquemática da deformação por maclação em um cristal.

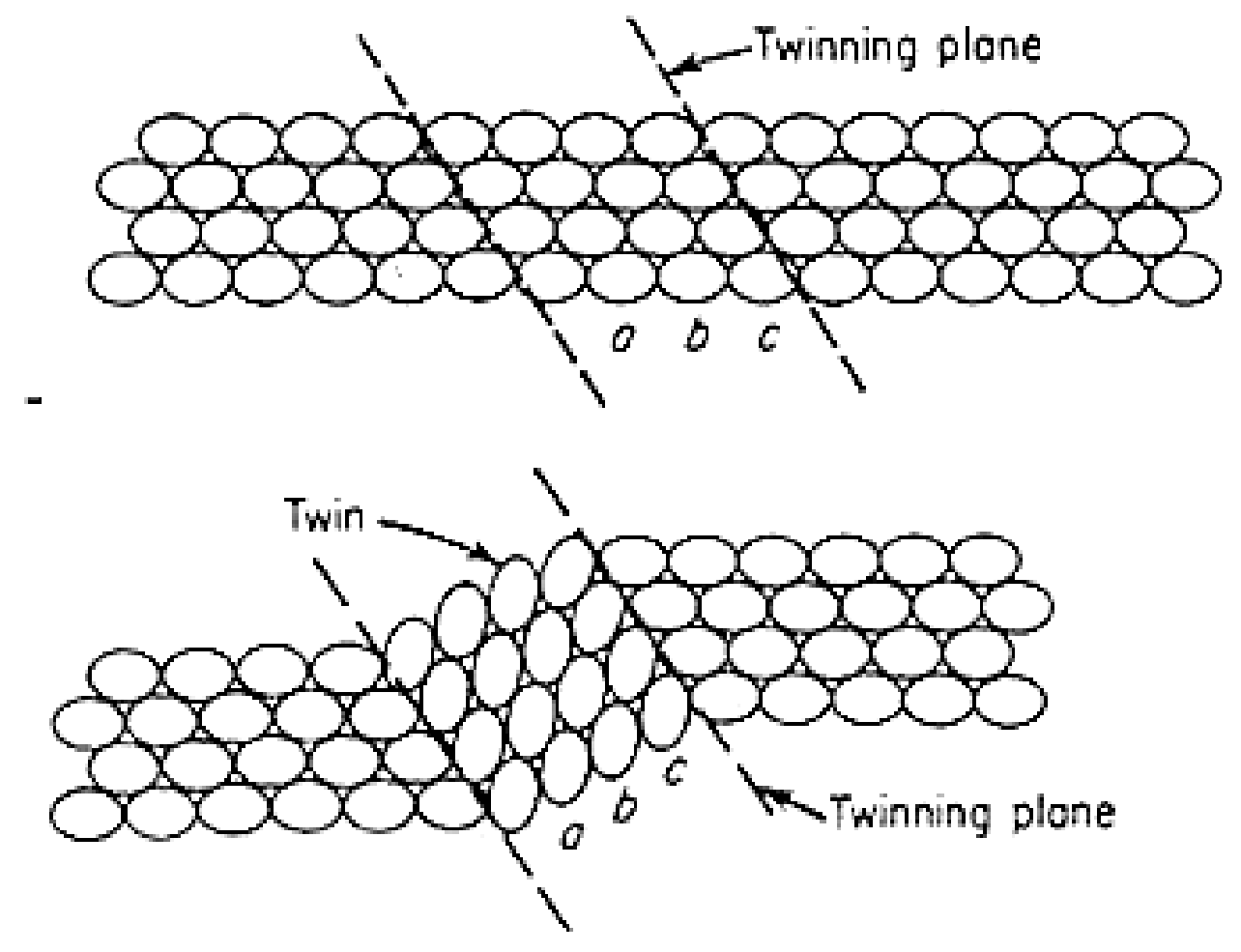

Fonte: Abbaschian, Reed-Hill, 1964. 
A maioria dos modelos de nucleação das maclas de deformação é baseada em reações de discordâncias, considerando que as maclas são formadas em heterogeneidades tais como o arranjo das discordâncias (Zhang et al, 2016). Na maioria dos metais, o escorregamento é o primeiro mecanismo de deformação plástica a ser ativado e então o núcleo da macla é formado pela alta concentração de tensão que existe na frente do empilhamento de discordâncias, produzida por um burst do escorregamento, como a operação das fontes de Frank-Read. A deformação por maclação em metais CFC resulta do cisalhamento homogêneo da matriz pelo deslizamento coordenado de discordâncias parciais de Shockley com o mesmo vetor de Burgers na família de planos $\{111\}$ (CHRISTIAN, 2002). Assim que as maclas são formadas, elas são propagadas em alta velocidade, visto que a tensão necessária para a nucleação das maclas é maior do que para a sua propagação.

A maclação depende da energia de falha de empilhamento, isso ocorre porque a energia superficial dos contornos de maclas está associada com a energia da falha de empilhamento. Quanto menor a energia de falha de empilhamento (EFE), menor é a tensão necessária para a nucleação de maclas. Kestenbach (KESTENBACH, 1976), Curtze e Kuokkala (CURTZE; KUOKKALA, 2010) mostraram que, a temperatura ambiente (273 K), para metais com elevada energia de falha de empilhamento $\left(>18 \mathrm{~mJ} / \mathrm{m}^{2}\right.$ ), a deformação ocorre pelo escorregamento, para valores intermediários da EFE (18 $-35 \mathrm{~mJ} / \mathrm{m}^{2}$ ) ocorreria a maclação mecânica e para valores mais baixos da EFE $\left(<18 \mathrm{~mJ} / \mathrm{m}^{2}\right)$ a transformação martensítica seria favorecida, conforme o diagrama da figura 14. A energia de falha de empilhamento é reduzida com o aumento do teor de solutos tais como $\mathrm{Mn}, \mathrm{Al}, \mathrm{Ni}$, que diminuem o desvio cruzado (cross-slip), confinando as discordâncias nas bandas em que a tensão de multiplicação das discordâncias promove a nucleação de maclas (KESTENBACH, 1976). 
Figura 14 - Energia de falha de empilhando em função da temperatura para um aço TWIP. O diagrama mostra as regiões de ocorrência de cada mecanismo de deformação plástica da austenita (escorregamento, maclação e transformação martensitica).

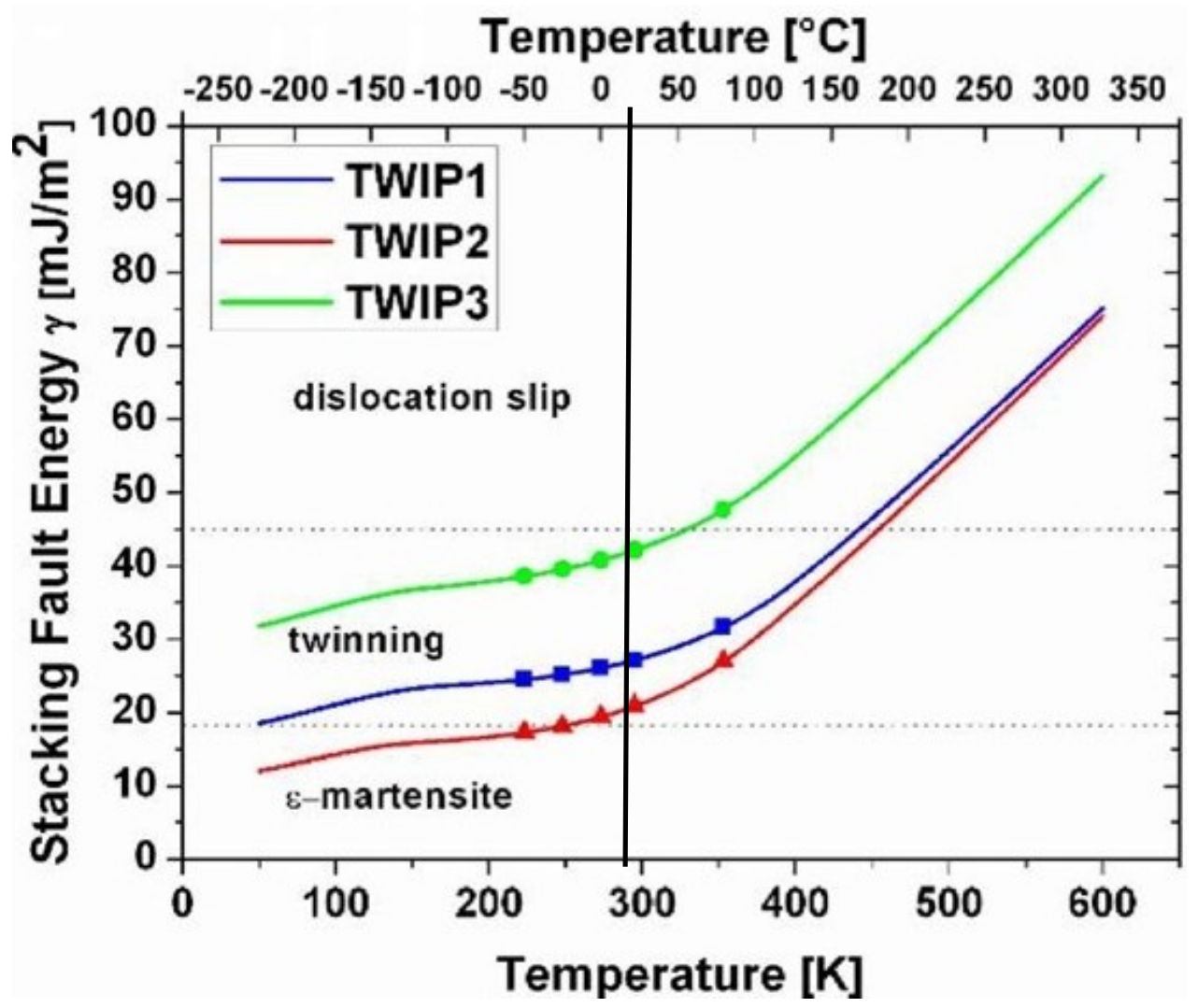

Fonte: Curtze; Kuokkala, 2010.

Kim et al (KIM ET AL, 2017) estudaram a função dos contornos de grão no mecanismo de deformação por maclação de um aço TWIP (16\% de Mn, $0,45 \%$ de $\mathrm{C}, 1,6 \% \mathrm{Al}$ e $1 \%$ de Si) através de ensaios de tração e caracterização microestrutural da superfície de fratura utilizando a técnica de microscopia eletrônica de transmissão. Seus resultados mostraram a formação de uma falha de empilhamento por discordâncias parciais de Shockley geradas nos contornos de grão. Isso indica que as maclas de deformação podem ser nucleadas nos contornos de grão. Os autores mostraram que as discordâncias envolvidas na nucleação das maclas de deformação são discordâncias perfeitas e discordâncias parciais de Shockley. Segundo os autores, a presença de discordâncias parciais de Frank dificultariam o movimento das discordâncias parciais de Shockley, o que seria responsável pela elevada taxa de encruamento dos aços TWIP. 


\subsection{EFEITO DO TAMANHO DE GRÃO NAS PROPRIEDADES MECÂNICAS DOS AÇOS}

As propriedades mecânicas dos materiais de engenharia podem ser melhoradas através de vários mecanismos de endurecimento, porém, também resultam em redução na tenacidade. A redução do tamanho de grão, que aumenta a quantidade de contornos de grão no material metálico policristalino, é o único meio de aumentar o limite de escoamento sem diminuir a tenacidade (CALLISTER, 2009; MORRIS, 2001; CHUNG, 2006; LLEWELLYN, 2013). O tamanho de grão pode ser controlado pela taxa de solidificação a partir de fase líquida, pela deformação plástica seguida de tratamento térmico adequado e pelo tratamento químico (HAAKONSEN, 2011).

A influência do tamanho de grão nas propriedades mecânicas dos aços é descrita matematicamente por uma série de equações constitutivas que possuem a forma da expressão de Hall-Petch (Equação 1) (HALL, 1951; PETCH, 1953). A relação de Hall-Petch é aplicada para uma faixa extensa de tamanhos, de alguns micrometros até milímetros (MORRIS, 2001).

$$
\sigma_{e}=\sigma_{o}+K_{H P} . d^{\frac{-1}{2}}(1)
$$

Sendo: $\sigma_{e}=$ tensão de escoamento $(\mathrm{MPa}), \sigma_{o}=$ tensão teórica para o limite de escoamento de um monocristal, $K_{H P}=$ constante de Hall-Petch e d $=$ tamanho de grão.

A aplicação da relação de Hall-Petch em uma análise da tensão de escoamento de materiais é complexa pois a estrutura é subdividida em contornos de diferentes características, que possuem diferentes resistências ao escoamento (ZHU et al, 2008). O mecanismo físico ainda não é completamente entendido, mas quatro modelos foram propostos para explicar a relação de Hall-Petch e cada modelo implica em uma expressão para o cálculo do parâmetro "kHP" (ZHU et al, 2008). No entanto, nenhum mecanismo tem sido quantificado em uma extensão que valide a expressão de Hall-Petch, que continua sendo considerada como empírica (ZHU et al, 2008). 
A hipótese original proposta por Hall (HALL, 1951) assume que a desorientação cristalográfica entre os grãos atua como obstáculos para o movimento das discordâncias (figura 15). Com o efeito da tensão de cisalhamento, as discordâncias serão empilhadas nos contornos de grão devido à repulsão do deslizamento e as discordâncias presentes nos contornos, assim o escorregamento ocorreria quando a tensão à frente do empilhamento atinge um valor crítico. Esse modelo foi observado apenas para metais CCC em baixas taxas de deformação, mas não tem evidências para metais CFC, e os valores do " $\mathrm{KH}$ " calculados para metais como a $\mathrm{Ag}$ e $\mathrm{Cu}$ foram maiores do que os obtidos experimentalmente (CONRAD, 1963).

Figura 15 - Figura esquemática do modelo de empilhamento de discordâncias no contorno de grão (obstáculo).

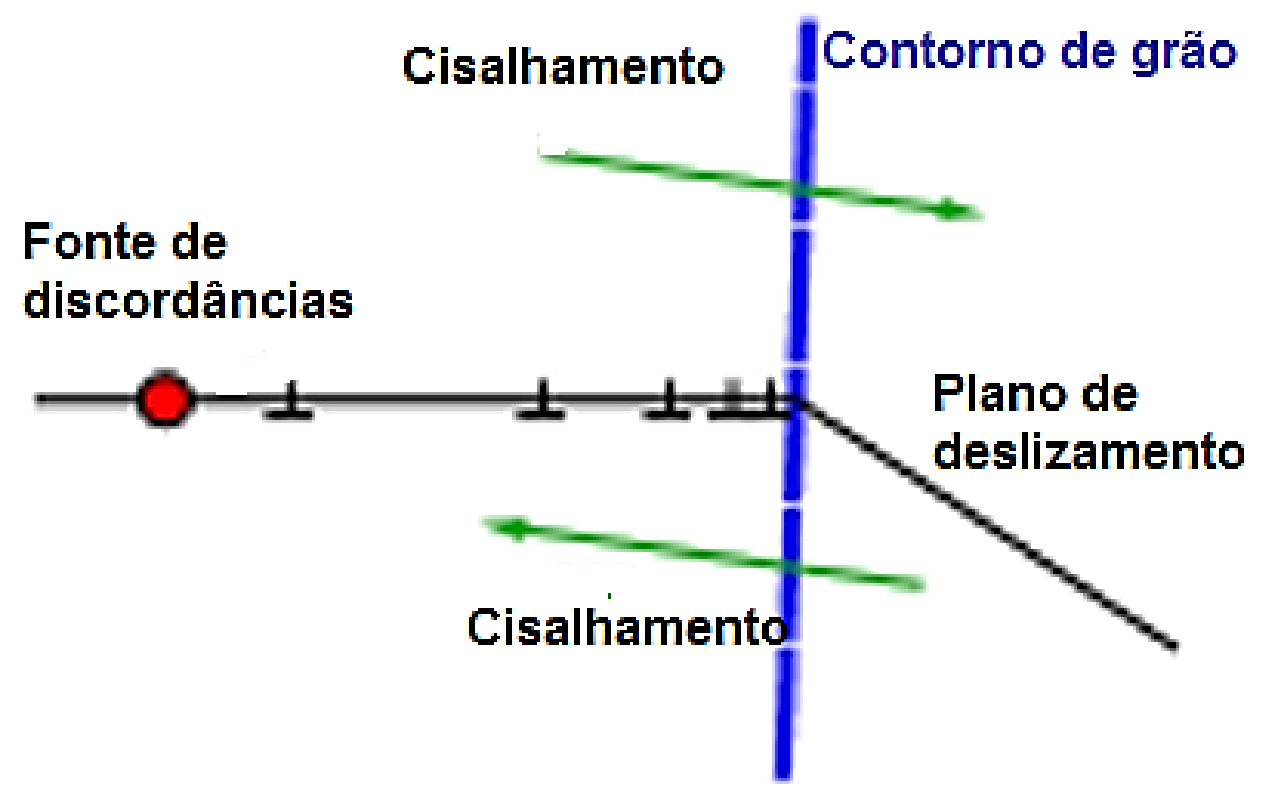

Fonte: Modificado de Zhu et al, 2016.

Li (LI, 1963) sugeriu que os contornos de grão e subgrãos, tanto de alto ângulo como baixo ângulo, são fontes de discordâncias. Com a penetração da discordância no campo de tensão ao redor do contorno de grão, seu vetor de Burgers muda de orientação, e então uma discordância é gerada para conservar o vetor de Burgers (HIRTH, 1972). Em casos mais complexos, três 
ou mais discordâncias são geradas, e tendem a sair dos contornos de grão. Outro mecanismo de geração de discordâncias nos contornos de grão é apresentado por Gleiter et al (GLEITER et al, 1968) sendo também baseado em reações a partir do escorregamento com as discordâncias nos contornos de grão. Alguns trabalhos (ZHU et al, 2016) mostram evidências experimentais de discordâncias sendo emitidas por contornos de grãos em metais policristalinos (figura 16). No entanto, esse modelo também é inconsistente com a maioria dos dados obtidos experimentalmente para metais.

Figura 16 - Modelo esquemático dos contornos de grão atuando como fontes de discordâncias (b) Imagem de MET de liga metálica de Ti-Mo, com discordâncias sendo geradas nos contornos de grão.

(a)

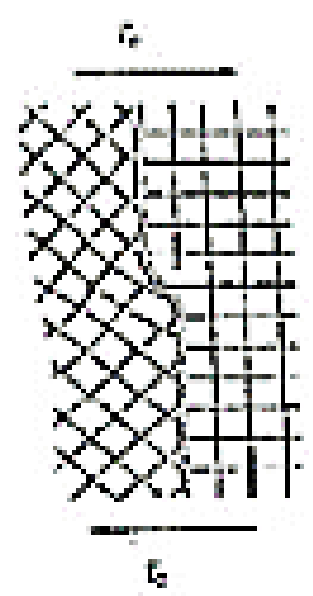

(b)

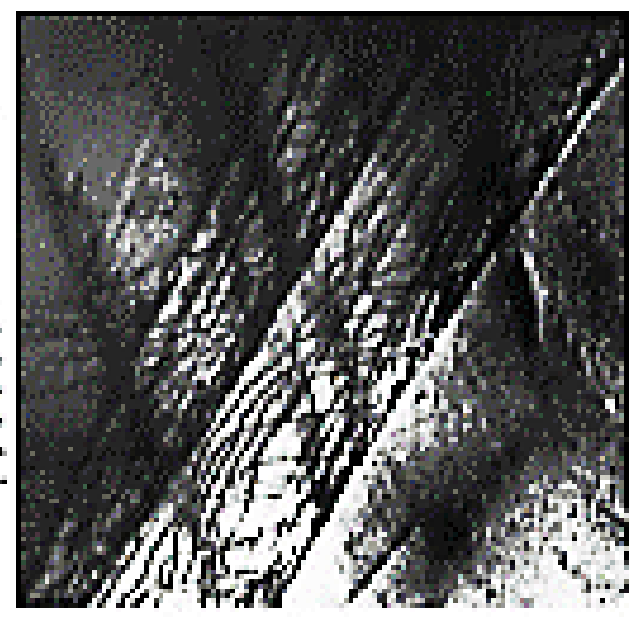

Fonte: Zhu et al, 2016.

Uma terceira interpretação proposta por Chia (CHIA, 2005) é baseada na relação entre o tamanho de grão e a densidade de discordâncias durante o escoamento (MORRIS, 2001). A presença de contornos de grão reduziria a distância média do movimento de discordâncias como esquematizado na figura 17, e assume-se que essa distância média é linearmente dependente do tamanho de grão. 
Figura 17 - Modelo esquemático da distância de deslizamento em materiais com tamanhos de grãos (a) pequenos e (b) largos.

(a)

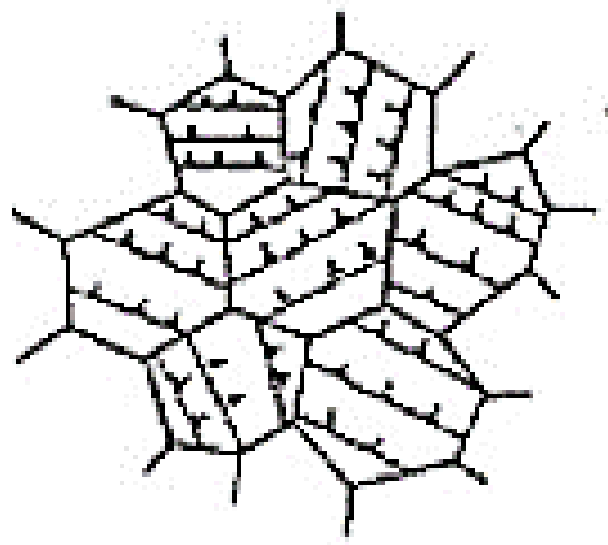

(b)

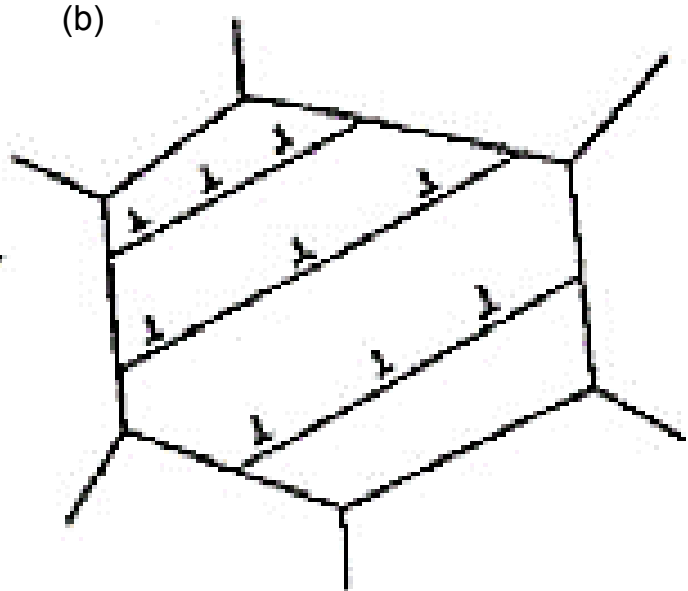

Fonte: Zhu et al, 2016.

O modelo mais recente, proposto por Ashby (ASHBY, 1971) baseia-se nas discordâncias geométricas. As discordâncias geométricas GNDs ocorrem nos contornos de grão para acomodar os gradientes da deformação, como vazios e superposições de discordâncias que podem surgir devido à deformação não homogênea entre os grãos adjacentes (figuras 18-a a 18-d). Em pequenos tamanhos de grãos, a densidade de discordâncias geométricas é alta (ZHU ET AL, 2016). 
Figura 18 - Representação esquemática do modelo proposto por Ashby (ASHBY, 1971) no qual (a) os grãos em materiais policristalinos deformam uniformemente e são formadas (b) vazios e superposições entre os grãos podendo ser corrigidos pela introdução de (c) e (d) discordâncias geométricas (GNDs).
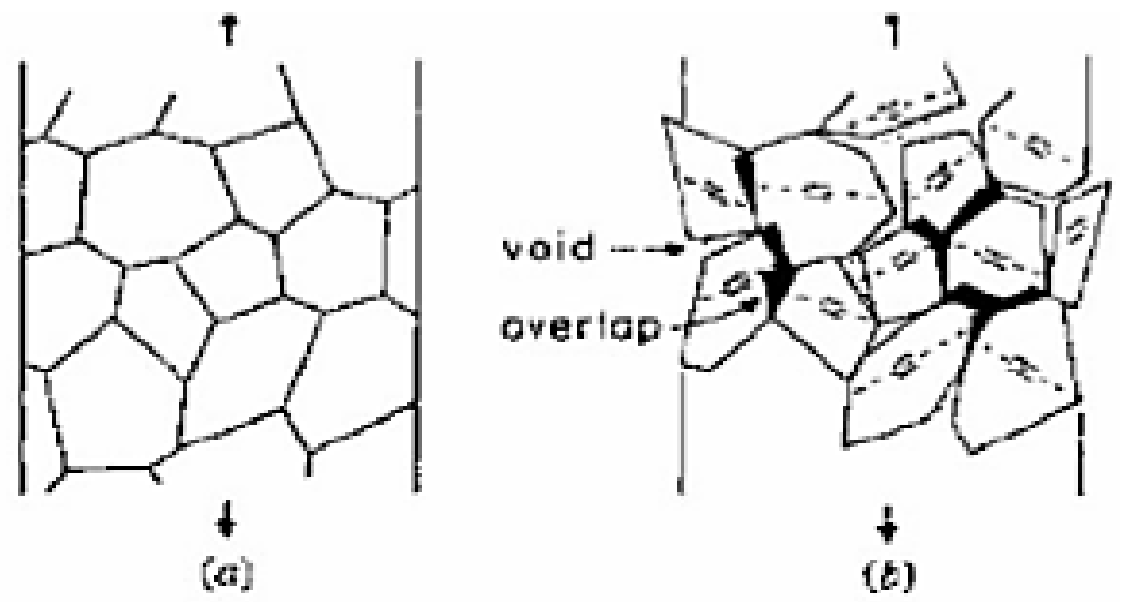

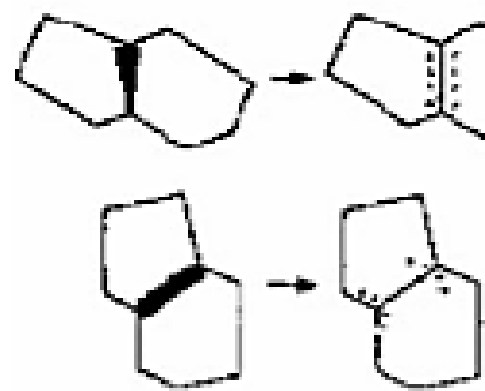

(c)

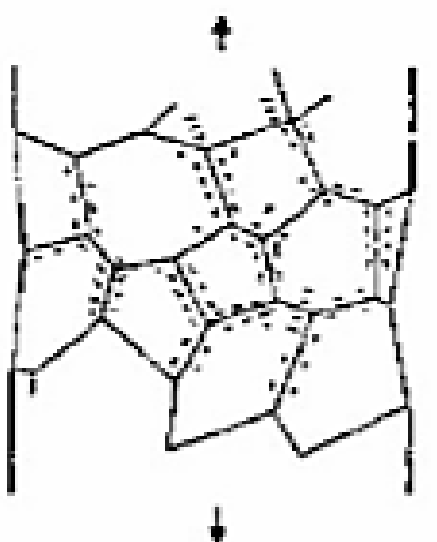

(d)

Fonte: Zhu et al, 2016.

$\mathrm{Na}$ determinação do tamanho de grão (d) presente na relação de HallPetch podem ser utilizados o diâmetro médio dos grãos, caminho livre médio e o máximo tamanho do grão dependendo do material e modelo adotados. Se os modelos de densidade de discordância e empilhamento das discordâncias forem utilizados, então a medida do caminho livre médio é mais significativa (MORRIS, 2001). O uso da média do tamanho de grão é difícil de ser justificada visto que o escoamento e a fratura refletem o comportamento de regiões "fracas" na microestrutura, o que estaria associado com os extremos na distribuição do tamanho de grão (MORRIS, 2001). No entanto, em materiais policristalinos com grãos equiaxiais ou que apresentam estreita distribuição dos 
tamanhos de grãos, a média do tamanho de grão pode ser tomada já que representa a microestrutura.

O valor correspondente ao expoente "n" do tamanho de grão na relação de Hall-Petch é questionável na literatura, estando na faixa de 0 a 1 (NARUTANI E TAKAMURA, 1991). Hutchison et al (HUTCHISON et al, 1972) estudaram a dependência da tensão de escoamento com o tamanho de grão em ligas de cobre, e o expoente correspondente a 1 foi o que mais se aproximou dos dados experimentais pelo método de regressão linear. Em contraste, Kocks (KOCKS, 1959) sugeriu que o expoente de $1 / 3$ é o mais adequado para a faixa de tamanho de grãos verificado experimentalmente para uma série de ligas metálicas.

Dunstan e Bushby (DUNSTAN E BUSHBY, 2016) estudaram a relação de Hall-Petch para diferentes ligas metálicas, como aço, cobre, alumínio, tungstênio, entre outros, considerando-se dados experimentais de artigos clássicos e recentes. Foi proposta a equação 2 descrita abaixo com base na análise bayesiana dos dados experimentais obtidos para a resistência mecânica mínima esperada para dado tamanho de grão, tomando-se a operação "In d/d" como sendo a aproximação mais coerente, ao invés de "d-1/2"

$$
\sigma_{e}=\sigma_{o}+K_{H P} \cdot \frac{\ln d}{d}
$$

Astaf'ev (ASTAF'EV, 1997) estudou a influência do tamanho de grão nas propriedades mecânicas, na taxa de encruamento e resistência à abrasão sobre impacto de aços ao manganês austeníticos de grau A da norma ASTM A128. Em aços ao manganês com grãos grandes $\left(n^{\circ} 1\right)$, a deformação de cisalhamento no grão é pequena pois existe somente um pequeno número de grãos orientados de modo favorável à direção da tensão atuante, por isso a deformação é concentrada nos contornos de grão (ASTAF'EV, 1997). Observou-se para tamanhos de grãos pequenos $\left(n^{\circ} 4\right.$ e 5$)$ que a deformação 
de cisalhamento é considerável no interior do grão, o que resultou em aumento na resistência a tração, alongamento e energia absorvida no impacto (figura 19). Os testes de resistência à abrasão sob impacto foram conduzidos em uma instalação que promove colisões das amostras analisadas com um abrasivo de granito. A resistência à abrasão sob impactos também aumentou com a redução dos tamanhos de grãos já que a deformação se concentra no interior dos grãos (ASTAF'EV, 1997).

Figura 19- Gráfico indicando a dependência da resistência à fratura $\left(\mathrm{N} / \mathrm{mm}^{2}\right)$, alongamento $(\%)$ e energia absorvida no impacto $\left(\mathrm{J} / \mathrm{cm}^{2}\right)$ com o tamanho de grão no aço ao manganês austenítico 110G13L.

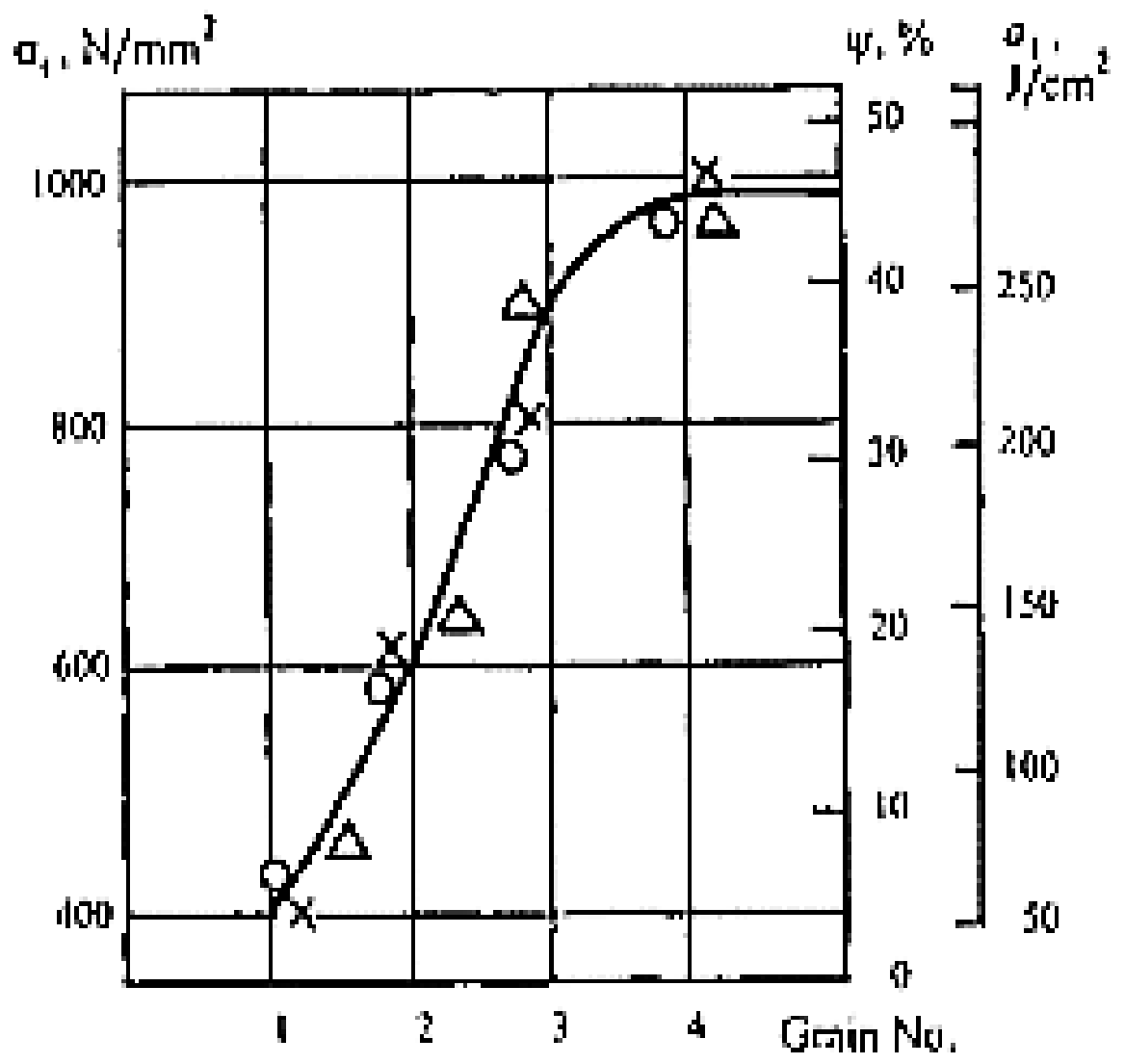

Fonte: Astaf'ev, 1997.

Karaman (KARAMAN, 2000) estudou o comportamento da curva de tensão - deformação para policristais de aço Hadfield (1,03\%C e 12,34\%Mn) com tamanhos de grão de 100, 300 e $1000 \mu \mathrm{m}$ produzidos através da laminação. A análise da figura 20 indica que o aço Hadfield com tamanho de 
grão de $100 \mu \mathrm{m}$ apresenta maior tensão de escoamento, módulo de elasticidade, resiliência, resistência à tração e resistência à fratura do que os demais tamanhos de grãos. O aço Hadfield com tamanho de grão de $300 \mu \mathrm{m}$ é o que possui maiores propriedades de alongamento e tenacidade. Karaman (KARAMAN, 2001) também estudou as atividades de maclas de deformação e discordância no interior dos grãos através de modelagem utilizando uma abordagem viscoplástica desenvolvida pelo autor. Os resultados mostraram que a maclação é o principal mecanismo de deformação plástica do aço Hadfield assim como em estudos experimentais anteriores realizados por Adler, Olson e Owen (ADLER, OLSON E OWEN, 1981. No entanto, segundo o autor, assim que a maclação domina a deformação plástica em todo o material, o escorregamento torna-se o mecanismo de deformação plástica predominante entre as maclas de deformação e no interior das regiões macladas. Dessa forma, quando os grãos são maclados, a subsequente atividade de maclação nessas regiões é limitada (KARAMAN, 2001).

Figura 20 - Curvas de tensão (MPa) - deformação do aço Hadfield com tamanhos de

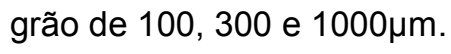

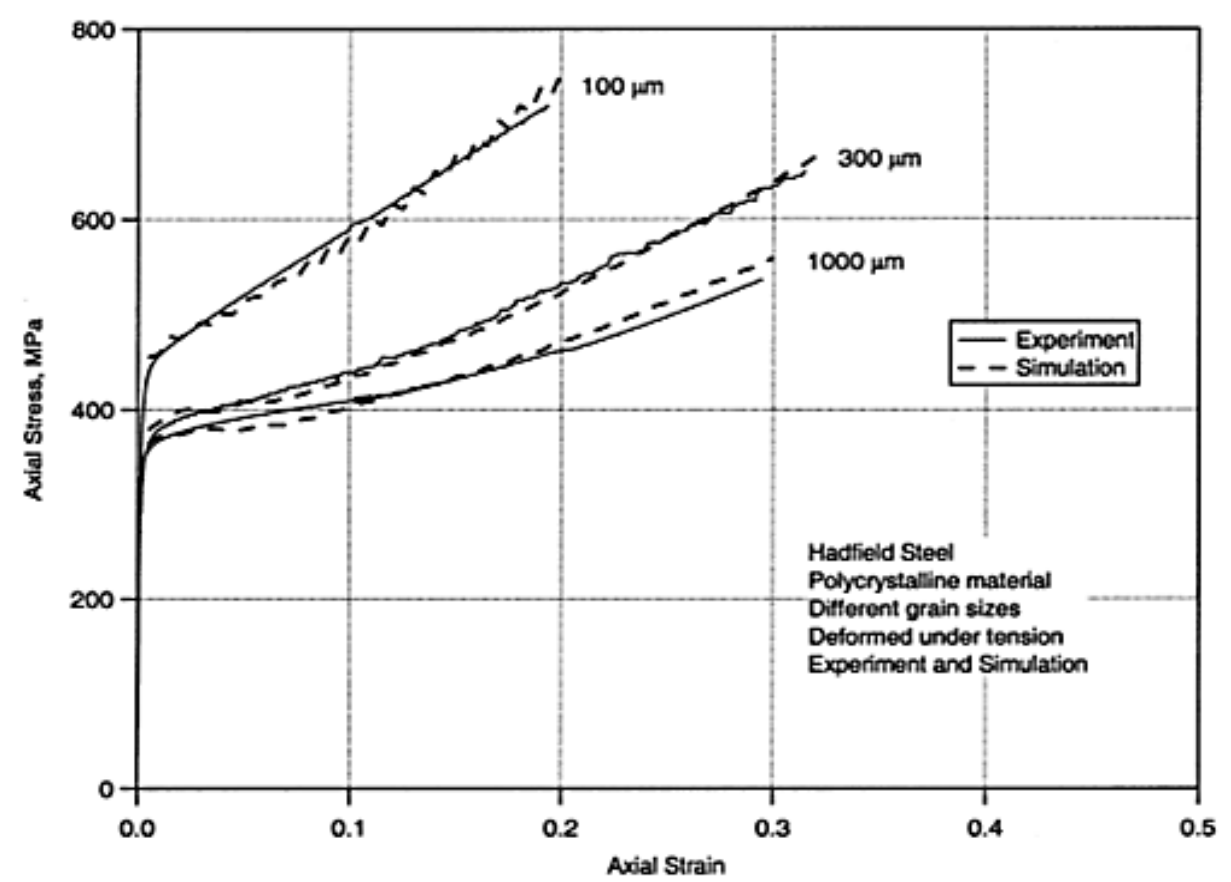

Fonte: Karaman, 2000. 


\subsubsection{Refino do tamanho do grão austenítico em aço Hadfield}

O refino do tamanho de grão pode ser promovido por inclusões nãometálicas que interferem na evolução da microestrutura durante a solidificação através da formação de sítios para a nucleação heterogênea ou contribuindo para o ancoramento do contorno de grão, dificultando o crescimento do grão (HAAKONSEN, 2011). A eficiência do substrato em promover a nucleação heterogênea depende do desajuste cristalográfico entre o substrato e o sólido nucleado (BRAMFITT, 1970). Óxidos, nitretos e sulfetos de Ti e Ce são comumente utilizados como elementos refinadores do tamanho de grão ferrítico já que possuem parâmetros cristalográficos semelhantes tendo pequeno desajuste do parâmetro de rede (figura 21) (GRONG, 1997).

Figura 21 - Relação entre o desajuste do parâmetro de rede e super resfriamento para diferentes agentes nucleadores (inoculantes) em aços.

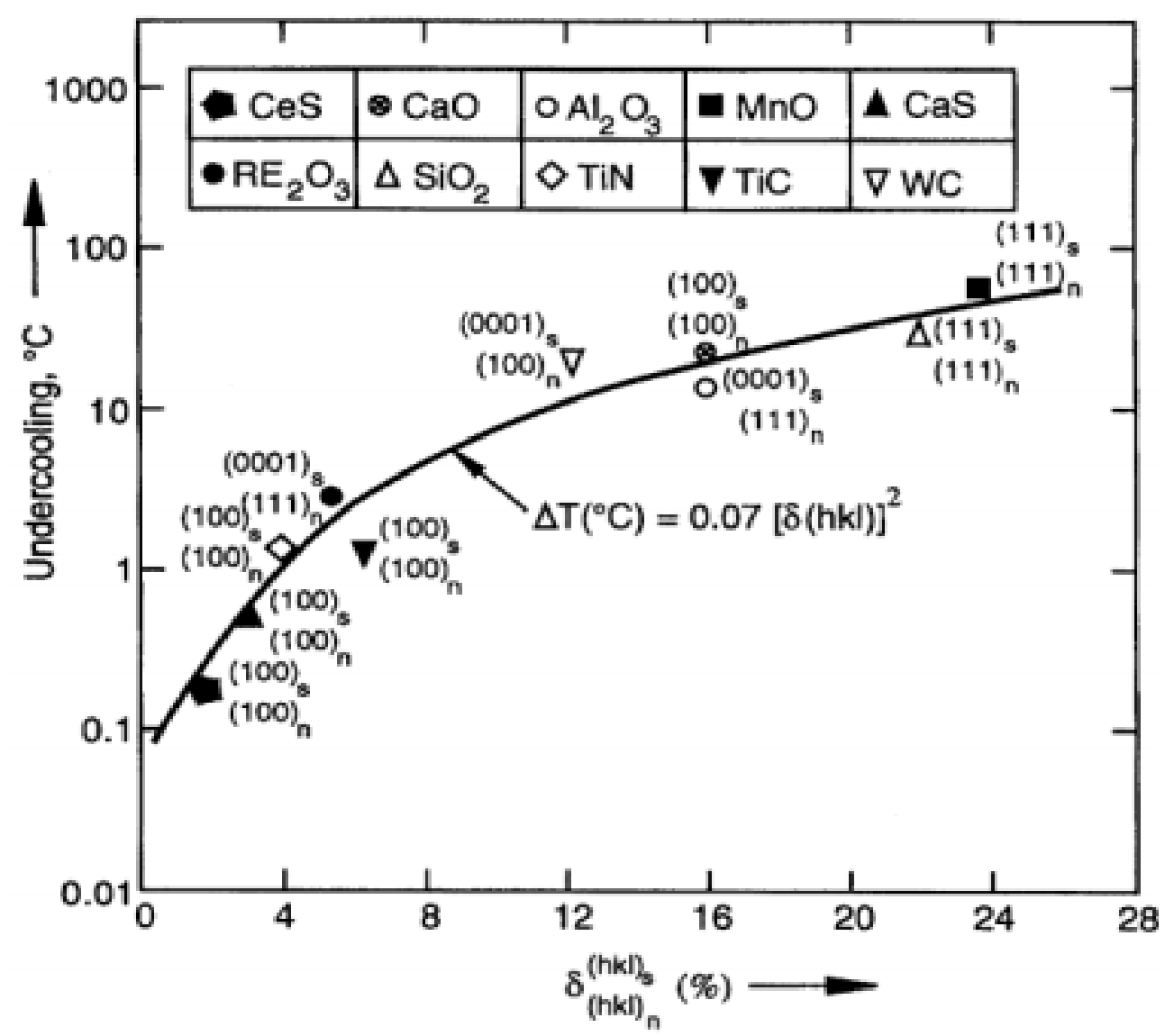

Fonte: Grong,1997. 
O uso de compostos com elementos de $\mathrm{Ti}, \mathrm{B}$ e $\mathrm{Ce}$ foram estudados como refinadores do tamanho de grão austenítico para aços de elevado teor de manganês. Sasakiet al (SASAKI et al, 2007) adicionaram 0-0,5 mol \% de $\mathrm{TiB}_{2}$ na proporção de 1:2 em aço carbono $\mathrm{S} 45 \mathrm{C}$ de matriz austenítica (porém a solidificação inicia-se com a fase ferrítica). Obtiveram redução no tamanho de grão austenítico de 1900 para $250 \mu \mathrm{m}$ nas adições de $0-0,2 \%$ em mol de $\mathrm{TiB}_{2}$ (figura 22), com taxa de resfriamento de $0,02 \mathrm{~K} / \mathrm{s}$. Porém, não foram verificadas reduções seguintes no tamanho de grão para as adições de 0,2-0,5\% em mol de $\mathrm{TiB}_{2}$ (SASAKI et al, 2007). O limite de redução do tamanho de grão de 250 $\mu \mathrm{m}$ é semelhante ao espaçamento dos braços das dendritas secundárias. Foi concluído através de análises micrográficas que as partículas de $\mathrm{TiB}_{2}$ e inclusões de $\mathrm{TiC}$ e $\mathrm{Fe}_{2} \mathrm{~B}$ são formadas nas posições interdendríticas durante e depois da solidificação, como no esquema da figura 23 , e são controladas pela migração do contorno de grão nas posições interdendríticas (SASAKI et al, 2007).

Figura 22 - Micrografias do (a) aço S45C sem adição de Ti e B; e (b) com adição de 0,2\% em mol de Ti e $0,4 \%$ em mol de B. Ataque químico: Nital 0,2\%. Aumento original de 50x.
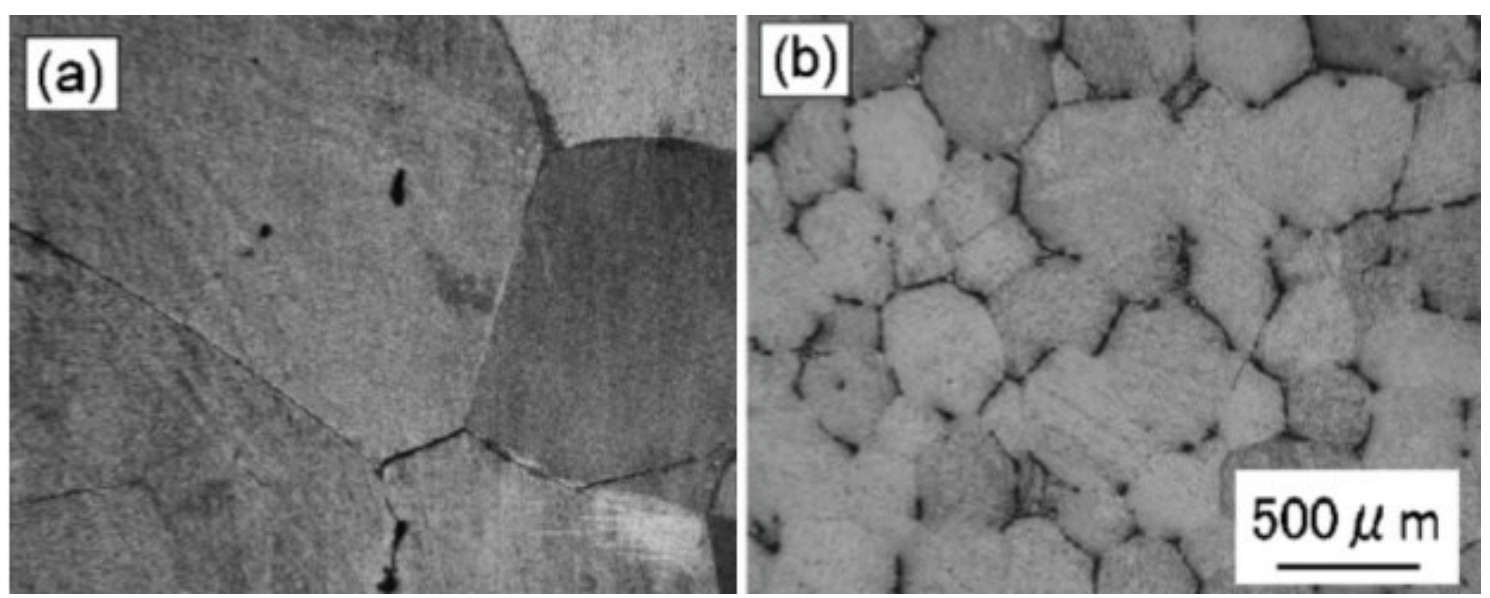

Fonte: Sasaki e Ohsasa, 2007. 
Figura 23 - Figura esquemática do efeito de ancoramento provocado pelas partículas de $\mathrm{TiB}_{2}$ e inclusões de $\mathrm{TiC}$ e $\mathrm{FeB}_{2}$ nas posições interdendríticas da austenita.

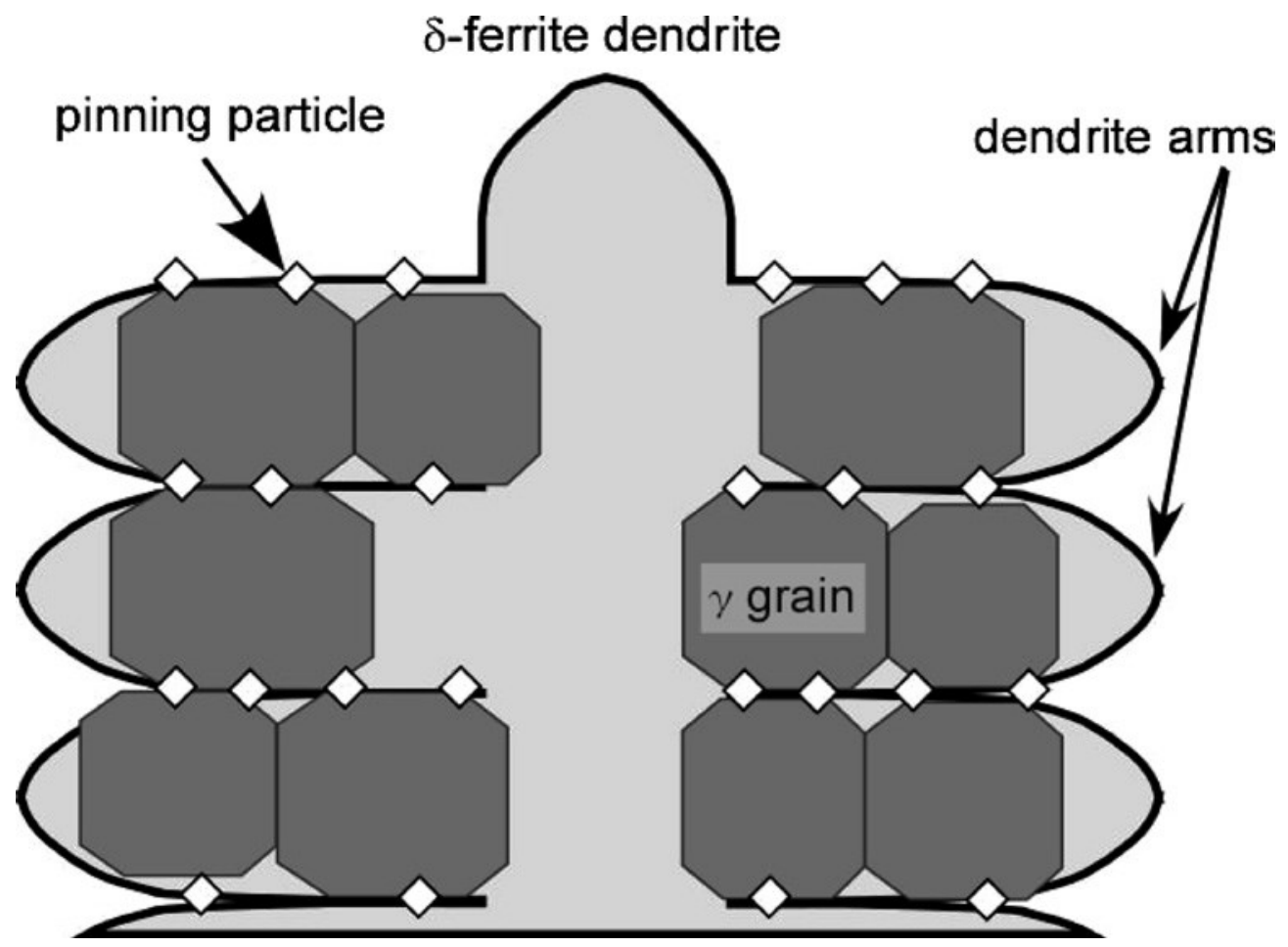

Fonte: Sasaki e Ohsasa,2007.

Haakonsen (HAAKONSEN, 2009) utilizou o Ce como refinador do grão austenítico em aços ao manganês, com teores variando de 0 a 0,05 medidos nas 8 amostras fundidas. Segundo o autor, o elemento $\mathrm{Ce}$ ao ser adicionado no banho metálico tende a formar óxidos e sulfetos que atuariam como sítios para a nucleação heterogênea da austenita. Os resultados mostraram que as adições entre 0 e $0,05 \%$ de Ce não possuem efeito significativo no tamanho de grão austenítico, e para a adição de $0,05 \%$ de $\mathrm{Ce}$, o tamanho de grão é reduzido de $570 \mu \mathrm{m}$ para $270 \mu \mathrm{m}$. No entanto, a temperatura de vazamento não foi controlada durante a fundição das amostras (variação de 1425 a $1402^{\circ} \mathrm{C}$ ) e pode ter influenciado os resultados de refino do tamanho de grão. A amostra que apresentou o menor tamanho de grão $(270 \mu \mathrm{m})$ foi fundida com a menor temperatura de vazamento $\left(1402^{\circ} \mathrm{C}\right)$, sugerindo que a temperatura de vazamento comprometeu os resultados de refino de tamanho de grão obtidos pelo autor (HAAKONSEN, 2009). 
O uso do háfnio como refinador do grão austenítico é descrito em patente europeia (OGUIZA, 2012). O Hf é adicionado em quantidades de 0,01-0,1\% em peso num aço Hadfield com 1,2\% C e 12,5\% Mn. A metodologia de adição do $\mathrm{Hf}$ não é descrita de forma detalhada, podendo ser realizada depositando-o nos moldes, na concha de fundição e no jato durante o vazamento. Na figura 24 tem-se a comparação da microestrutura do aço Hadfield com adição de $\mathrm{Ce} \mathrm{e}$ do aço Hadfield com adição de Hf. As propriedades mecânicas do aço Hadfield com adição de $\mathrm{Hf}$ são descritas na tabela 3, observa-se que apresenta uma combinação de elevada resistência à tração e limite de escoamento com alta ductilidade.

Figura 24 - Comparação entre (a) aço Hadfield com adição de Ce e; (b) aço Hadfield com adição de $\mathrm{Hf}$.

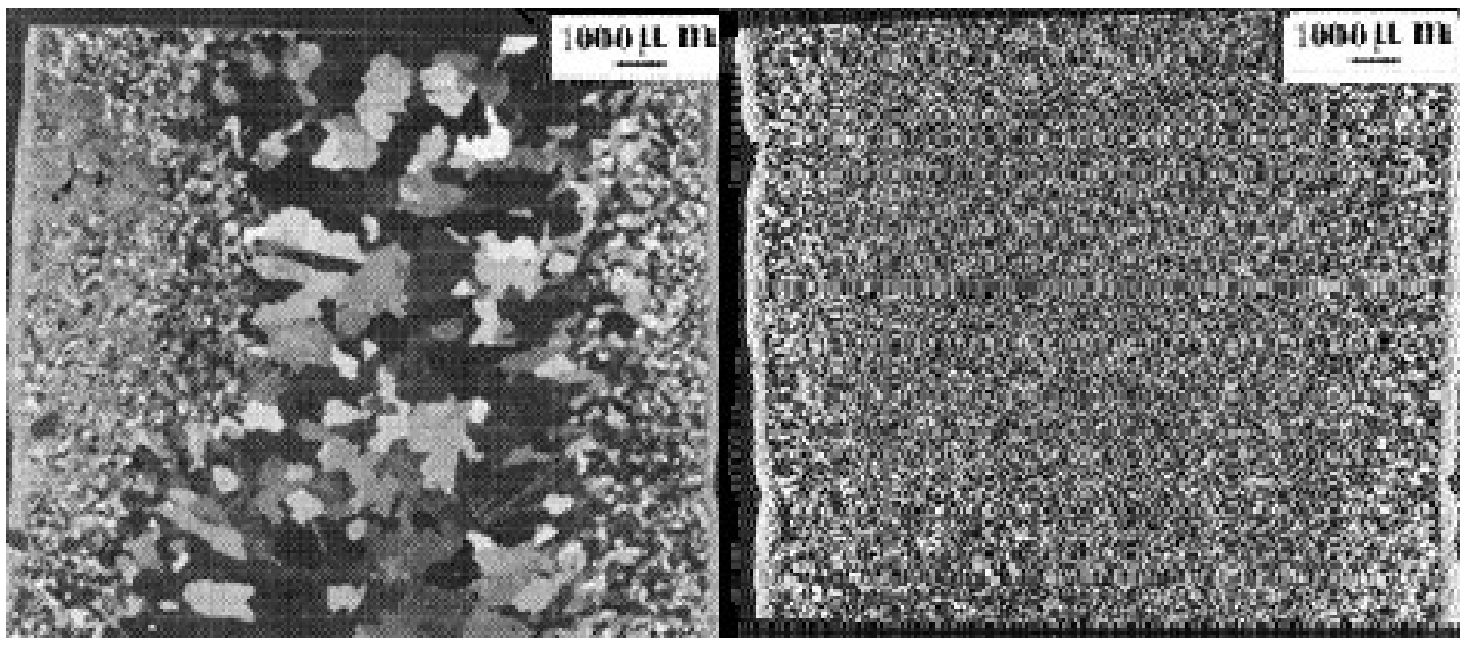

Fonte: Modificado de Oguiza, 2012.

Tabela 4- Propriedades mecânicas do aço Hadfield com adição de Hf.

\begin{tabular}{|c|c|c|c|c|c|}
\hline & $\begin{array}{c}\text { Resistência a } \\
\text { tração (MPa) }\end{array}$ & $\begin{array}{c}\text { Tensão de } \\
\text { escoamento } \\
\text { (MPa) }\end{array}$ & $\begin{array}{c}\text { Alongament } \\
\mathbf{0 ~ ( \% )}\end{array}$ & $\begin{array}{c}\text { Resiliênci } \\
\mathbf{a}(\mathbf{J})\end{array}$ & $\begin{array}{c}\text { Durez } \\
\mathbf{a}\end{array}$ \\
(HB)
\end{tabular}

Fonte: Oguiza, 2012. 


\section{MATERIAIS E MÉTODOS}

Neste capítulo são apresentados os materiais de estudo e a descrição dos procedimentos experimentais para a produção dos corpos de prova de aço Hadfield grau B2 da norma ASTM A128 (ASTM A128, 2012), caracterização macro e microestrutural das amostras, a avaliação das propriedades mecânicas dos corpos de prova e suas respectivas fractografias.

\subsection{PRODUÇÃO DOS CORPOS DE PROVA DE AÇO HADFIELD}

\subsubsection{Simulações microestruturais de solidificação usando o software Thermo-Calc}

Foram realizadas simulações no Thermo-Calc 2016a usando os seguintes bancos de dados:

- TCFE8- Thermo-Calc Steels/Fe-Alloys v.80 (THERMOCALC, 2016) para caracterizar o caminho de solidificação e evolução microestrutural do aço Hadfield sem refino com composição química de $13 \%$ de $\mathrm{Mn}, 1,2 \%$ de $\mathrm{C}$ e $0,65 \%$ de $\mathrm{Si}$;

- SSOL4- Alloy Solutions v.49g (THERMOCALC, 2016) para caracterizar o caminho de solidificação e evolução microestrutural de um aço Hadfield refinado com $0,1 \% \mathrm{Hf}$ com composição química de $13 \%$ de $\mathrm{Mn}$, $1,2 \%$ de $\mathrm{C}$ e $0,65 \%$ de $\mathrm{Si}$, e para determinar a temperatura de formação do carboneto de Hf (NIELSEN, 2000).

\subsubsection{Fundição dos corpos de prova}

As corridas experimentais foram realizadas no forno de indução Inducto 50 (figura 25) com capacidade nominal de $20 \mathrm{Kg}$ (disponível no IPT- Instituto de Pesquisas Tecnológicas), com as matérias primas descritas na tabela 5, 
utilizando o argônio para a proteção do banho metálico e adição de alumínio $(0,1 \%)$ para a desoxidação do banho metálico.

Tabela 5 - Matéria prima utilizada para a preparação das corridas experimentais de aço Hadfield.

\begin{tabular}{|c|c|c|c|c|c|c|c|}
\hline & Fornecedor & $\% \mathbf{C}$ & $\% \mathbf{M n}$ & $\% \mathbf{S i}$ & $\% \mathbf{C r}$ & $\% \mathbf{P}$ & $\% \mathbf{S}$ \\
\hline Sucata & TruferLtda & 0,18 & 0,6 & 0,23 & - & 0,01 & 0,02 \\
& & & & & & & \\
\hline Fe-Mn-C & MundiligasLtda & 6,78 & 77,13 & 1,35 & 6,78 & 0,14 & 0,02 \\
\hline Fe-Si & MundiligasLtda & 0,1 & - & 76,7 & - & - & - \\
\hline
\end{tabular}

Figura 25 - Forno de indução Inducto 50 utilizado para as corridas experimentais

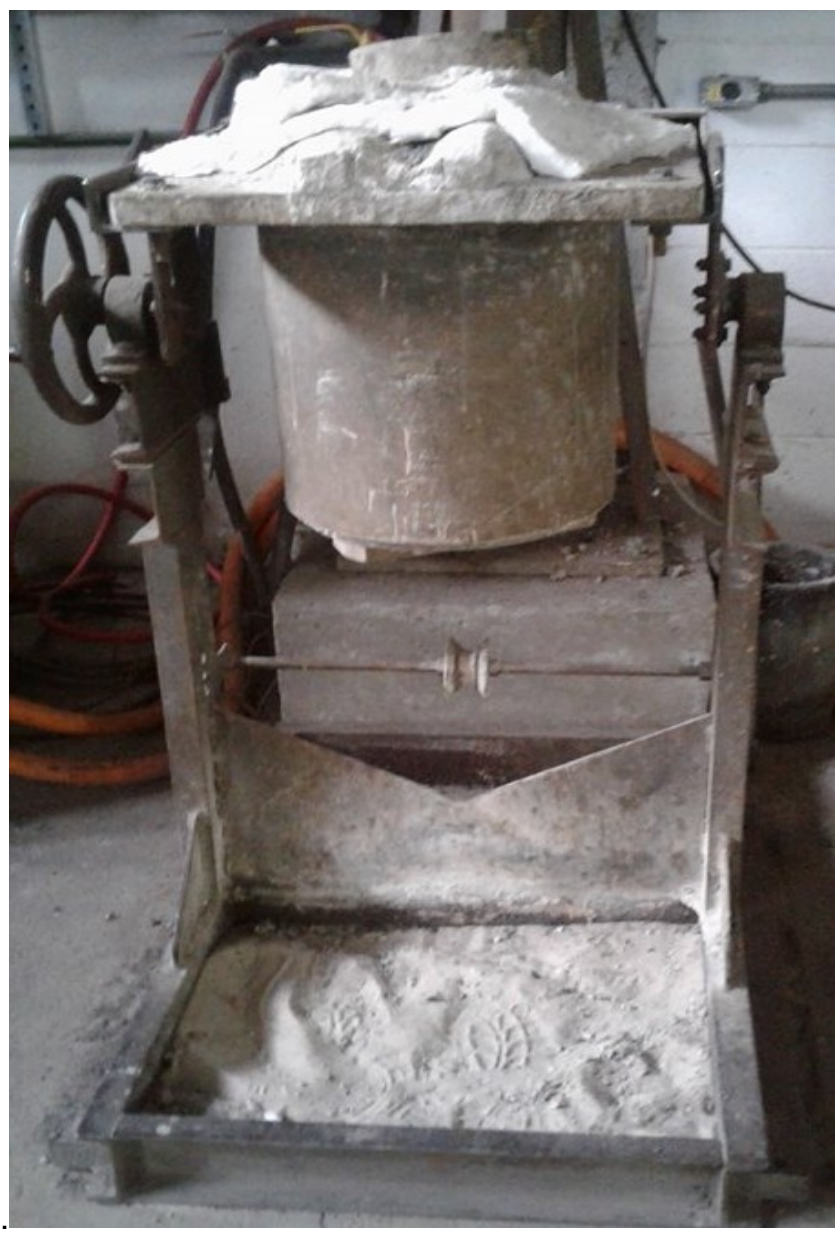


Foram fundidas 02 peças do tipo "keel block" (figura 26-a) e 03 blocos (dimensões de $60 \times 40 \times 80 \mathrm{~mm}$, vide figura 26-b) para as duas condições investigadas: aço Hadfield grau B2 da norma ASTM A128 sem refino e aço Hadfield grau B2 da norma ASTM A128 refinado com Hf. A temperatura de vazamento dos corpos de prova foi medida através do pirômetro Italterm Fornero II. Esta temperatura foi mantida em torno de $1430-1450^{\circ} \mathrm{C}$ em todas as corridas experimentais realizadas.

Figura 26 - Peças fundidas do aço Hadfield. (a) Peça do tipo "keel block" com 12,5 cm de comprimento; (b) Peça fundida no formato de bloco $60 \times 40 \times 80 \mathrm{~mm}$.

(a)

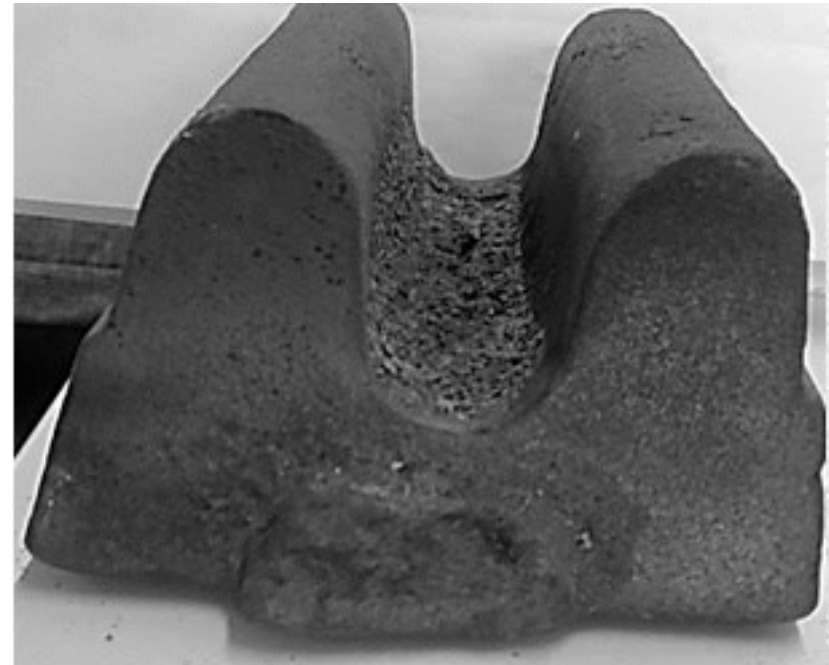

(b)

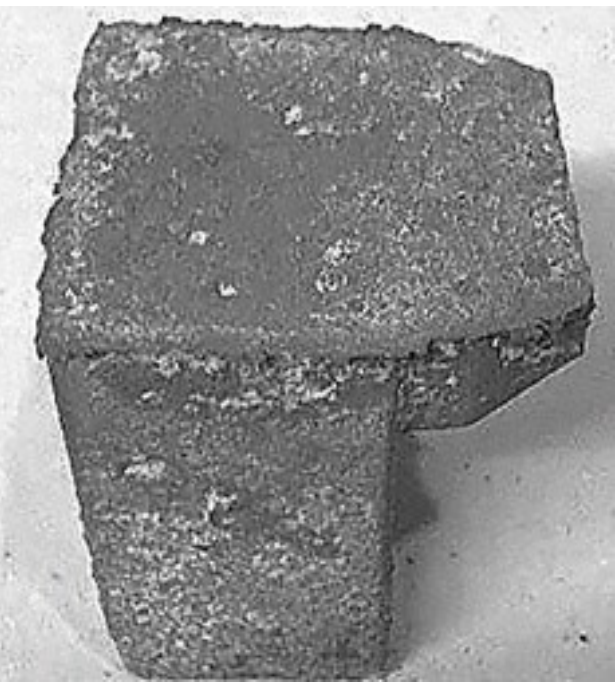

Foi desenvolvido um estudo do processo de adição do háfnio para a obtenção da microestrutura fundida refinada, visto que a descrição da metodologia de refino de aço Hadfield usando a adição do $\mathrm{Hf}$ na patente europeia não é descrita de forma detalhada (OGUIZA, 2012). Foram estudadas as seguintes variáveis para o processo do refino da microestrutura de solidificação do aço Hadfield grau B2 da norma ASTM A128:

- Morfologia das partículas de Hf metálico (placas versus cavacos);

- Modo de adição do Hf (direto no forno como carga ou na panela de vazamento); 
- Tempo para a dissolução do Hf (0 a 15 minutos) antes do vazamento no molde (tanto no forno como na panela);

- Efeito do teor de nitrogênio do aço Hadfield grau B2 da norma ASTM A128.

$\mathrm{Na}$ tabela 6 observa-se um resumo das corridas experimentais realizadas para a obtenção do aço Hadfield grau B2 da norma ASTM A128 refinado com $0,1 \% \mathrm{Hf}$.

Tabela 6 - Resumo das corridas experimentais para obtenção do aço Hadfield grau B2 da norma ASTM A128 refinado com $\mathrm{Hf}$.

\begin{tabular}{|c|c|c|c|c|c|}
\hline $\begin{array}{c}\text { Corridas } \\
\text { experimentais }\end{array}$ & $\begin{array}{l}\text { Morfologia } \\
\text { do Hf }\end{array}$ & $\begin{array}{l}\text { Modo de } \\
\text { adição }\end{array}$ & $\begin{array}{l}\text { Tempo para } \\
\text { dissolução }\end{array}$ & $\begin{array}{c}\text { Modelo da } \\
\text { peça }\end{array}$ & $\begin{array}{l}\text { Sucesso } \\
\text { no refino }\end{array}$ \\
\hline 1 & Cavaco & Jato & Imediatamente & "keel block" & Não \\
\hline 2 & Cavaco & Jato & Imediatamente & Blocos & Não \\
\hline 3 & Cavaco & Jato & Imediatamente & Blocos & Sim \\
\hline 4 & Cavaco & Jato & Imediatamente & Blocos & Não \\
\hline 5 & \multirow{4}{*}{ Placas } & & $5^{\prime}$ & \multirow{4}{*}{ Copo AT } & \\
\hline 6 & & Forno & $15^{\prime}$ & & \\
\hline 7 & & $\begin{array}{l}\text { Forno- } \\
\text { adição de } \\
\text { Fe-Cr-N }\end{array}$ & Imediatamente & & Não \\
\hline 8 & & Forno & $5^{\prime}$ & & Sim \\
\hline 9 & Placas & Forno & $5^{\prime}$ & Blocos & Sim \\
\hline 10 & Placas & Forno & $5^{\prime}$ & "keel block" & Sim \\
\hline
\end{tabular}

Foi adicionado $0,1 \% \mathrm{Hf}$ em cada uma das dez corridas realizadas. Foram testadas a adição do $\mathrm{Hf}$ metálico no formato de placas (com dimensões de $8 \times 2 \times 8 \mathrm{~mm}$ ) e cavacos (com espessura de $2 \mathrm{~mm}$, vide figura 27) no banho metálico e no jato do forno para a panela. No total, foram realizadas dez corridas experimentais, sendo que três corridas experimentais exploratórias foram realizadas no forno Inducto $50 \mathrm{com}$ cadinho de capacidade nominal de 3 $\mathrm{kg}$ utilizando copos de análise térmica (figura 28 ) como molde. O procedimento de refino mais eficiente foi com a adição de $0,1 \%$ em massa de placas de $\mathrm{Hf}$ no banho metálico (no forno) em temperaturas da ordem de $1600^{\circ} \mathrm{C}$ e tempo de 
manutenção nesta temperatura de 5 minutos antes do vazamento para a panela. A eficiência do refino foi determinada através da comparação dos resultados de caracterização macroestrutural das amostras na região central do corpo de prova.

Figura 27 - Morfologias de háfnio metálico utilizado no processo de refino microestrutural de peças fundidas de aço Hadfield refinado no formato de (a) cavacos (espessura de $2 \mathrm{~mm}$ ); (b) placas (dimensões de $8 \times 2 \times 8 \mathrm{~mm}$ ).

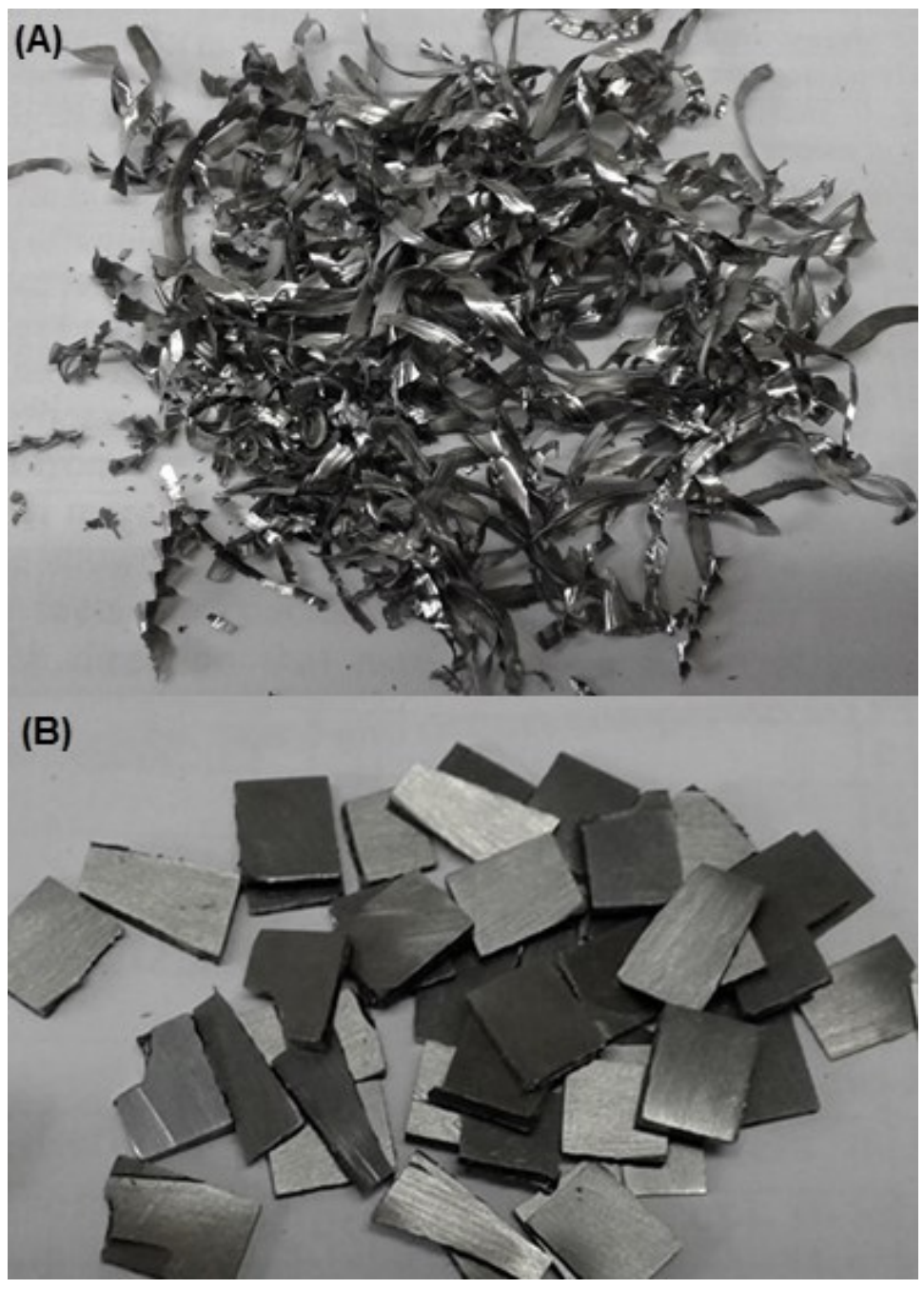


Figura 28 - Copos de análise térmica (com $50 \mathrm{~mm}$ de altura e $30 \mathrm{~mm}$ de diâmetro) com capacidade nominal de $300 \mathrm{~g}$ utilizados como molde para as corridas experimentais teste.

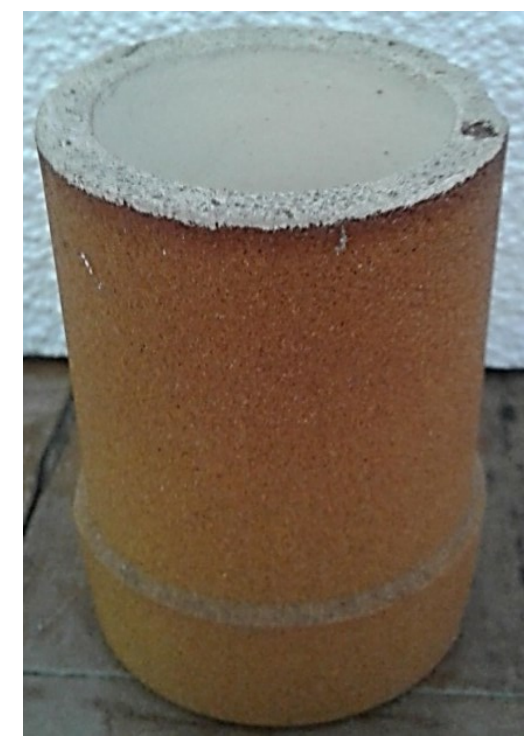

\subsubsection{Análise química das amostras}

A determinação da composição química das amostras de aço Hadfield grau B-2 da ASTM A128 foi realizada no Centro de Tecnologia em Metalurgia e Materiais (CTMM) do IPT. As análises químicas de Si, Mn, P e Cr no aço foram realizadas pela técnica de espectroscopia de fluorescência de raios $X$ no equipamento Shimadzu XRF 1500. A determinação dos teores de C e S no aço foi realizada por combustão direta e detecção de IF no equipamento LECO CS 300. O teor de $\mathrm{N}$ no aço foi medido por termo condutividade no LECO ONM 836. Todos os equipamentos usados para análise química fazem parte do sistema de qualidade do IPT, sendo calibrados regularmente. As composições químicas das amostras investigadas de aço Hadfield estão de acordo com as especificações químicas descritas na ASTM A128, grau B-2 (vide na tabela 7). 
Tabela 7 - Composição química das amostras de aço Hadfield

\begin{tabular}{|c|c|c|c|c|c|c|c|}
\hline Amostras & $\% \mathbf{C}$ & $\% \mathbf{S i}$ & $\% \mathbf{M n}$ & $\mathbf{\%} \mathbf{r}$ & $\% \mathbf{P}$ & $\% \mathbf{S}$ & $\% \mathbf{N}$ \\
\hline $\begin{array}{c}\text { Aço Hadfield } \\
\text { sem refino } \\
\text { (bloco) }\end{array}$ & 1,22 & 0,65 & 12,25 & 0,0033 & 0,033 & 0,037 & 0,0207 \\
\hline $\begin{array}{c}\text { Aço Hadfield } \\
\text { sem refino } \\
\text { ("keel block") }\end{array}$ & 1,23 & 0,64 & 11,98 & 0,0049 & 0,034 & 0,037 & 0,0178 \\
\hline $\begin{array}{c}\text { Aço Hadfield } \\
\text { refinado com } \\
\text { Hf (bloco) }\end{array}$ & 1,21 & 0,7 & 11,97 & 0,0037 & 0,033 & 0,037 & 0,0188 \\
\hline $\begin{array}{c}\text { Aço Hadfield } \\
\text { refinado com } \\
\text { Hf ("keel } \\
\text { block") }\end{array}$ & 1,24 & 0,8 & 11,83 & 0,0035 & 0,034 & 0,037 & 0,0192 \\
\hline
\end{tabular}

O háfnio metálico foi analisado de forma semi-quantitativa pela técnica de microanálise química EDS acoplado ao MEV Jeol JSM 6300 usando o modo sem padrão e aplicando a correção ZAF (Z: número atômico, A: probabilidade de absorção, $F$ : fluorescência de raios- $X$ secundária). Os resultados de microanálise química EDS indicaram que o háfnio metálico utilizado nas corridas experimentais para obtenção do aço Hadfield refinado apresenta 98,6\% em massa de $\mathrm{Hf}$ e 1,4\% em massa de $\mathrm{Zr}$ (vide espectro da figura 29). 
Figura 29 - (a) Espectro de microanálise química EDS da placa de Hf e (b) Imagem de MEV da região da placa de $\mathrm{Hf}$ em que a microanálise EDS foi realizada.

(a)

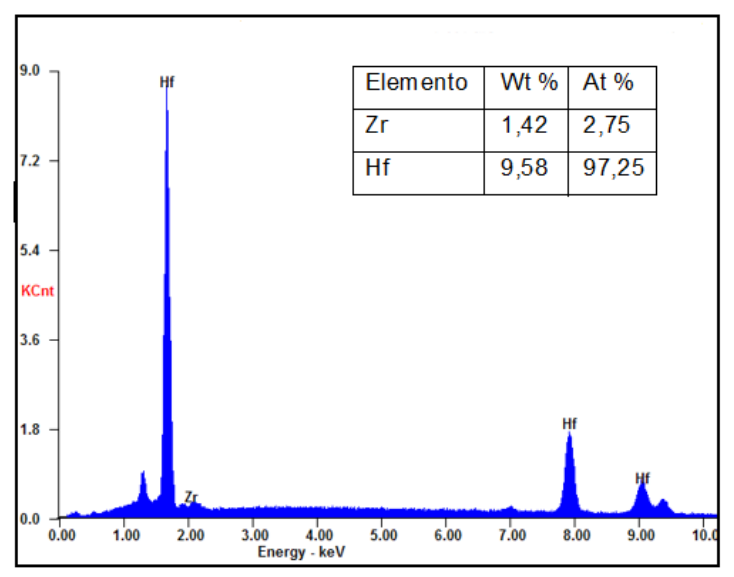

(b)

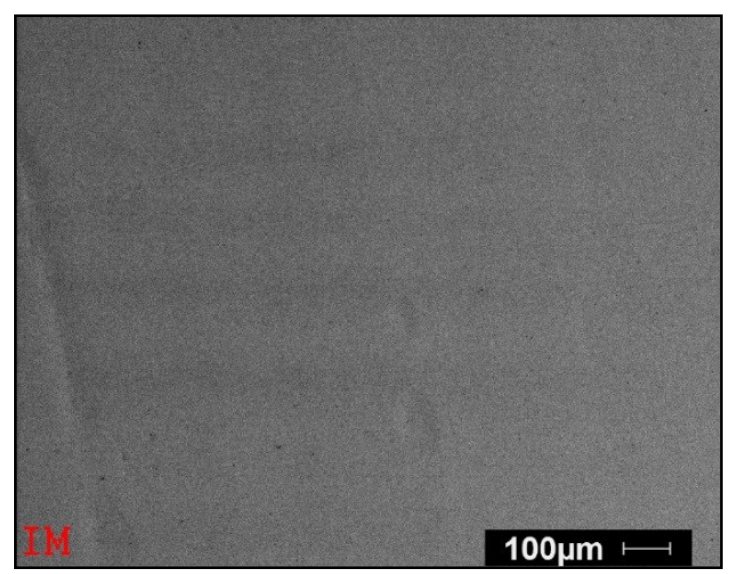

\subsection{CARACTERIZAÇÃO MACRO E MICROESTRUTURAL}

As amostras fundidas e tratadas termicamente (tratamento de solubilização) de aço Hadfield foram preparadas através das técnicas convencionais de metalografia que envolvem as etapas de: corte; lixamento com lixas de SiC com \#100, \#240, \#320, \#400, \#600 e \#1200; polimento com pasta de diamante com granulometria de \#6, \#4 e \#1; e ataque químico com Nital (3 ml de ácido nítrico, $97 \mathrm{ml}$ de álcool etílico) e com imersão de 50-120 s.

As peças de aço Hadfield foram submetidas ao tratamento térmico de solubilização à $1120^{\circ} \mathrm{C}$ por $10 \mathrm{~h}$ (blocos) e $4 \mathrm{~h}$ ("keel block") no forno Lindberg seguido por resfriamento em água agitada (60I) a temperatura ambiente, como esquematizado na figura 30 . Foi realizado um experimento utilizando a temperatura de manutenção à $1120^{\circ} \mathrm{C}$ de $10 \mathrm{~h}$ no "keel block", porém foi formada uma camada de descarbonetação espessa (com aproximadamente 5 $\mathrm{mm}$ ), por isso o tempo de manutenção á $1120^{\circ} \mathrm{C}$ do "keel block" foi reduzido para 4h. Durante o tratamento térmico de solubilização do aço Hadfield, foi observado que não ocorreu o crescimento do grão austenítico 
Figura 30 - Curvas de tratamento térmico de solubilização das peças de aço Hadfield.

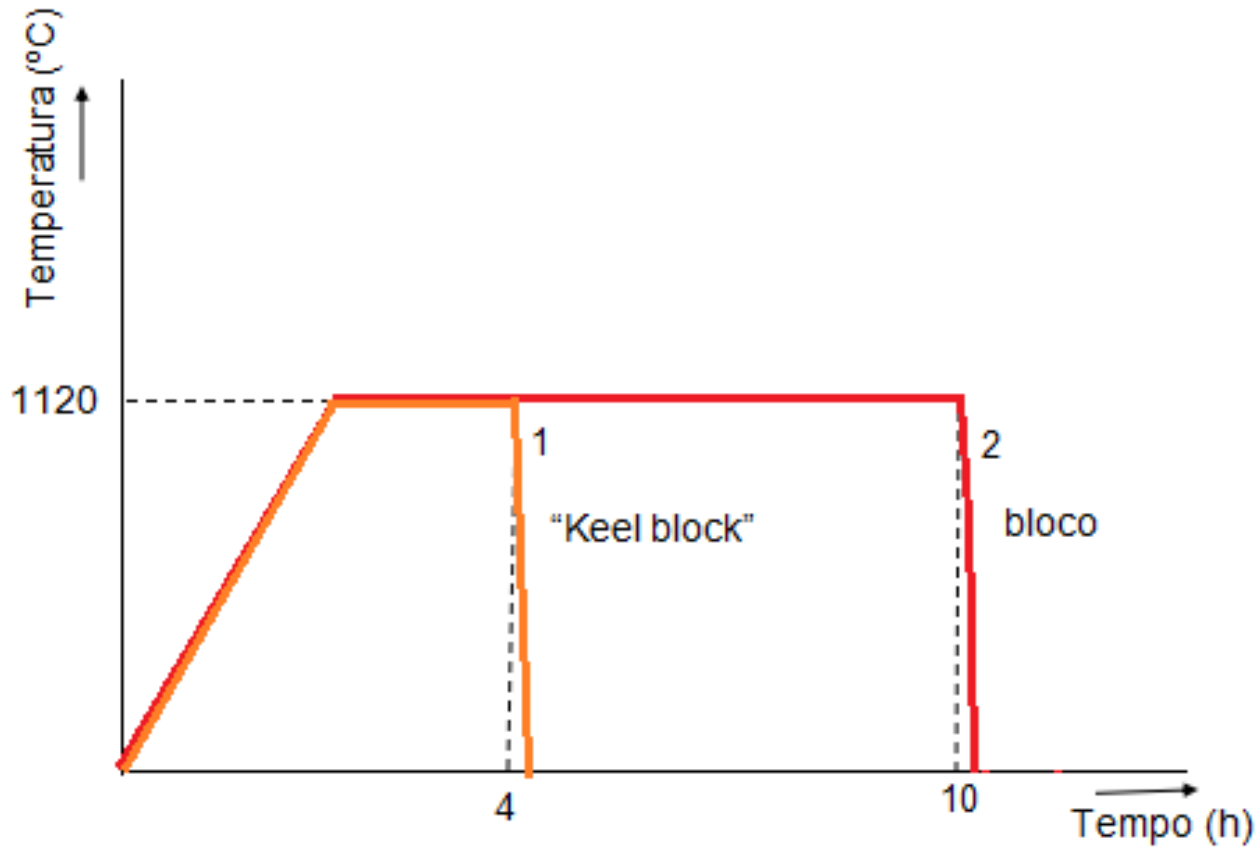

A região de retirada das amostras da peça de aço Hadfield para a caracterização microestrutural está esquematizada na figura 31. A microestrutura foi observada na lupa CITOVAL 2, no microscópio óptico (MO) Nikon EPIPHOT 200 e no microscópio eletrônico de varredura (MEV) Jeol JSM 6300. Todos estes equipamentos pertencem ao Centro de Tecnologia em Metalurgia e Materiais (CTMM) do IPT. 
Figura 31 - Figura esquemática da região de extração das amostras para caracterização macro e microestrutural.

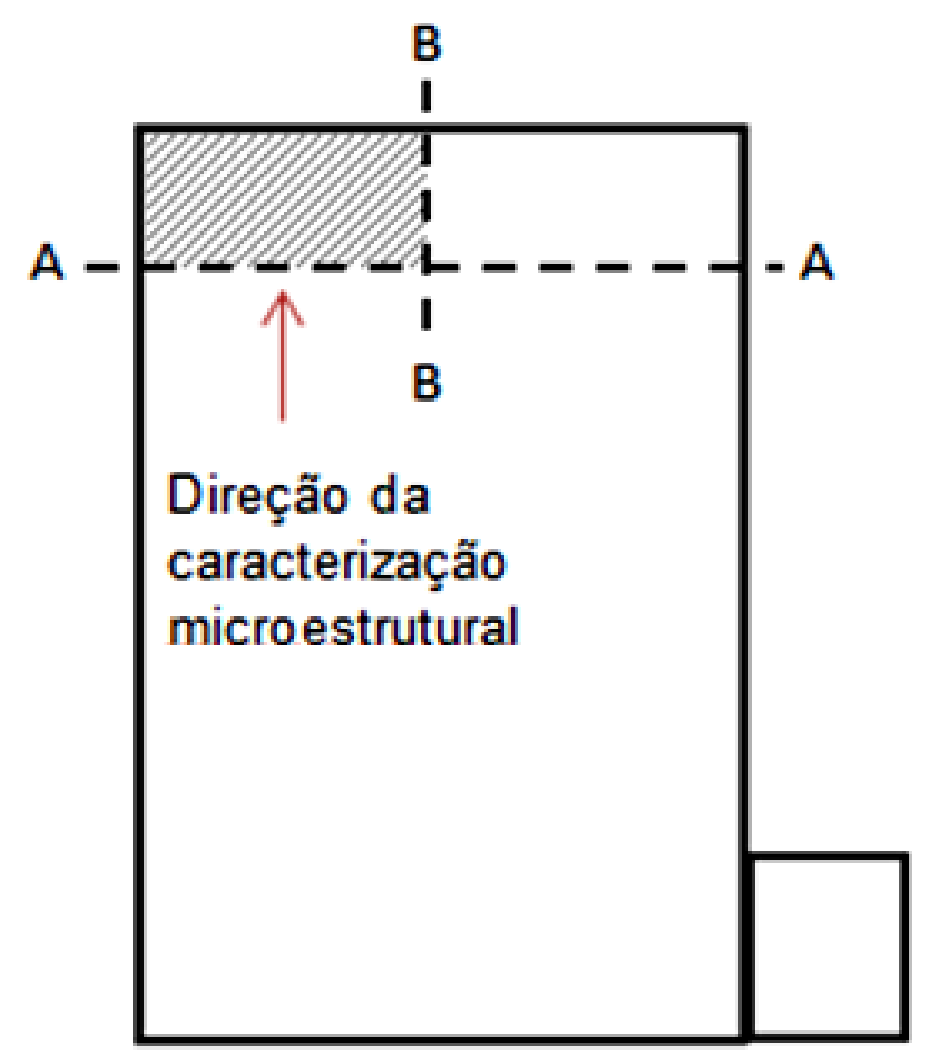

Foram utilizados três métodos macroestruturais e um método microestrutural de medida do tamanho de grão austenítico das amostras de aço Hadfield.

Inicialmente, o tamanho de grão foi medido como sendo a média entre a maior dimensão e a menor dimensão do grão austenítico obtido durante exame macroestrutural das amostras atacadas quimicamente (figura 32-a). As medidas do tamanho de grão austenítico foram realizadas para cinco campos para cada amostra durante exame macrográfico (lupa) dos corpos de prova atacados (aço Hadfield sem refino e refinado).

O método das intersecções também foi utilizado para a determinação do tamanho de grão, segundo a norma ASTM E112-96, em que é executada uma análise linear do número de grãos por tamanho da linha teste durante exame macroscópico de amostras atacadas quimicamente (figura 32-b). As medidas do tamanho de grão austenítico foram realizadas para cinco campos para cada 
amostra durante exame macrográfico (lupa CITOVAL 2) de corpos de prova atacados (aço Hadfield sem refino e refinado).

Para o aço Hadfield sem refino, a medida do tamanho de grão foi realizada separadamente para as zonas colunar e equiaxial, sendo que na zona colunar, o tamanho de grão foi tomado como sendo a maior dimensão do grão. As medidas do tamanho de grão austenítico foram realizados para cinco campos para cada amostra durante exame macrográfico (lupa CITOVAL 2) de corpos de prova atacados (aço Hadfield sem refino e refinado).

Finalmente, os resultados da técnica de EBSD foram utilizados para medir o tamanho de grão das amostras refinadas. As medidas foram realizadas para três campos durante exame microscópico no MEV de corpos de prova atacados (aço Hadfield refinado com).

Figura 32- Métodos de medidas do tamanho de grão. (a) Tamanho de grão determinado pela média entre a maior e menor dimensão do grão; (b) Método do intercepto linear segundo a norma ASTM E112-96

(a)

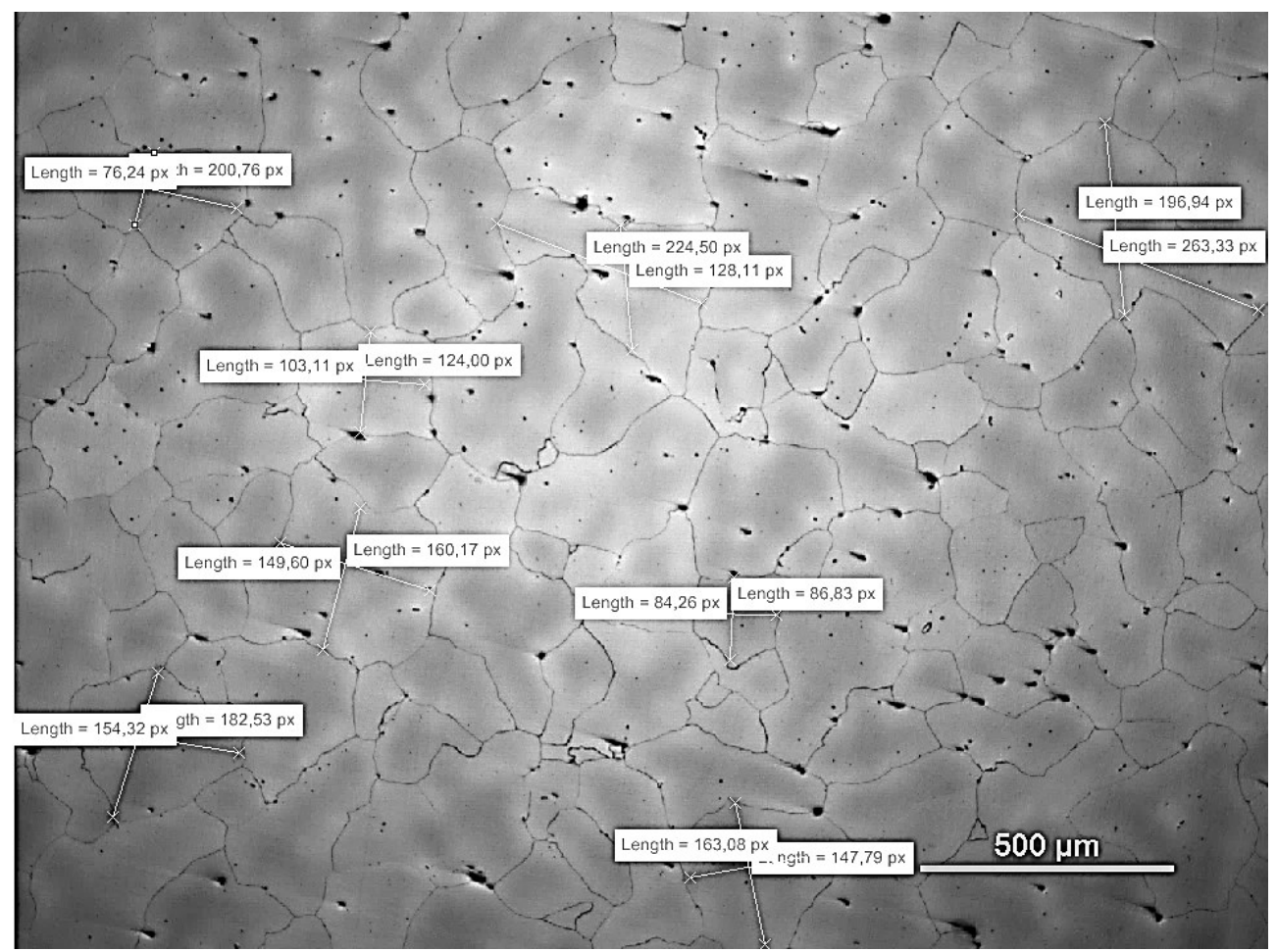


(b)

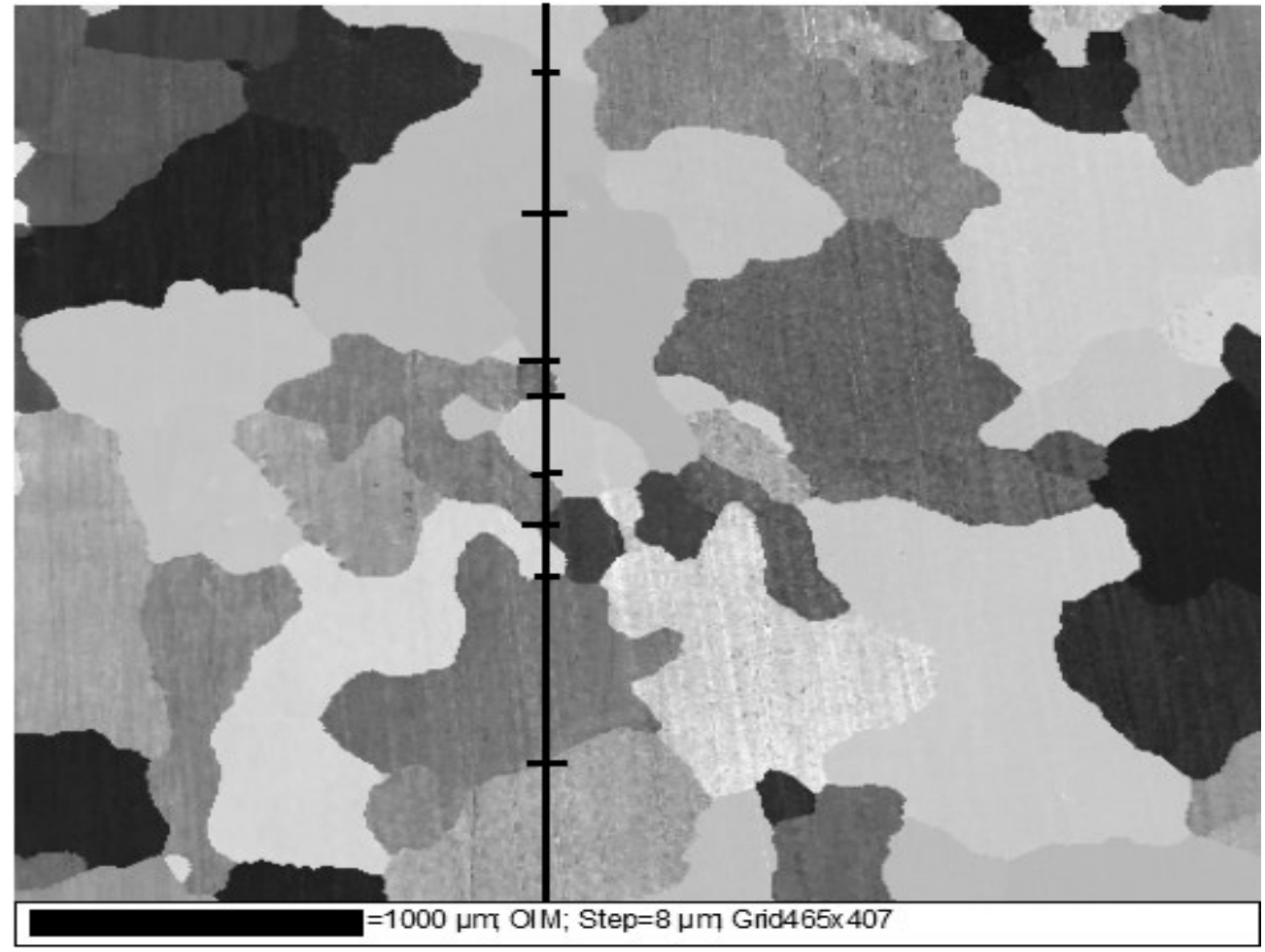

O software Nikon Nis Elements 3.0 foi utilizado para a determinação da fração pontual e em área das microporosidades e inclusões presentes nos corpos de prova do bloco e "keel block" de aço Hadfield. A fração pontual das microporosidades e inclusões foi medida através da aplicação de uma rede sobre a imagem da microestrutura obtida por um microscópio óptico. O número de pontos coincidentes entre a rede e as microporosidades/inclusões foi contado e dividido pelo número total de intersecções da rede (figura 33-a). A fração volumétrica pode ser considerada como sendo a fração pontual para medidas efetuadas aleatoriamente em superfícies polidas e para constituintes distribuídos de forma uniforme no material, como é o caso das inclusões presentes no material de estudo (SEABRA, 1979). A fração em área das microporosidades foi determinada pelo software Nikon Nis Elements 3.0 utilizando ajuste manual da área selecionada pelo software (figura 33-b). 
Figura 33 - Métodos para a determinação da fração pontual (a) e em área (b) das microporosidades presentes nos corpos de prova extraídos do bloco e "keel block" de aço Hadfield.

(a)

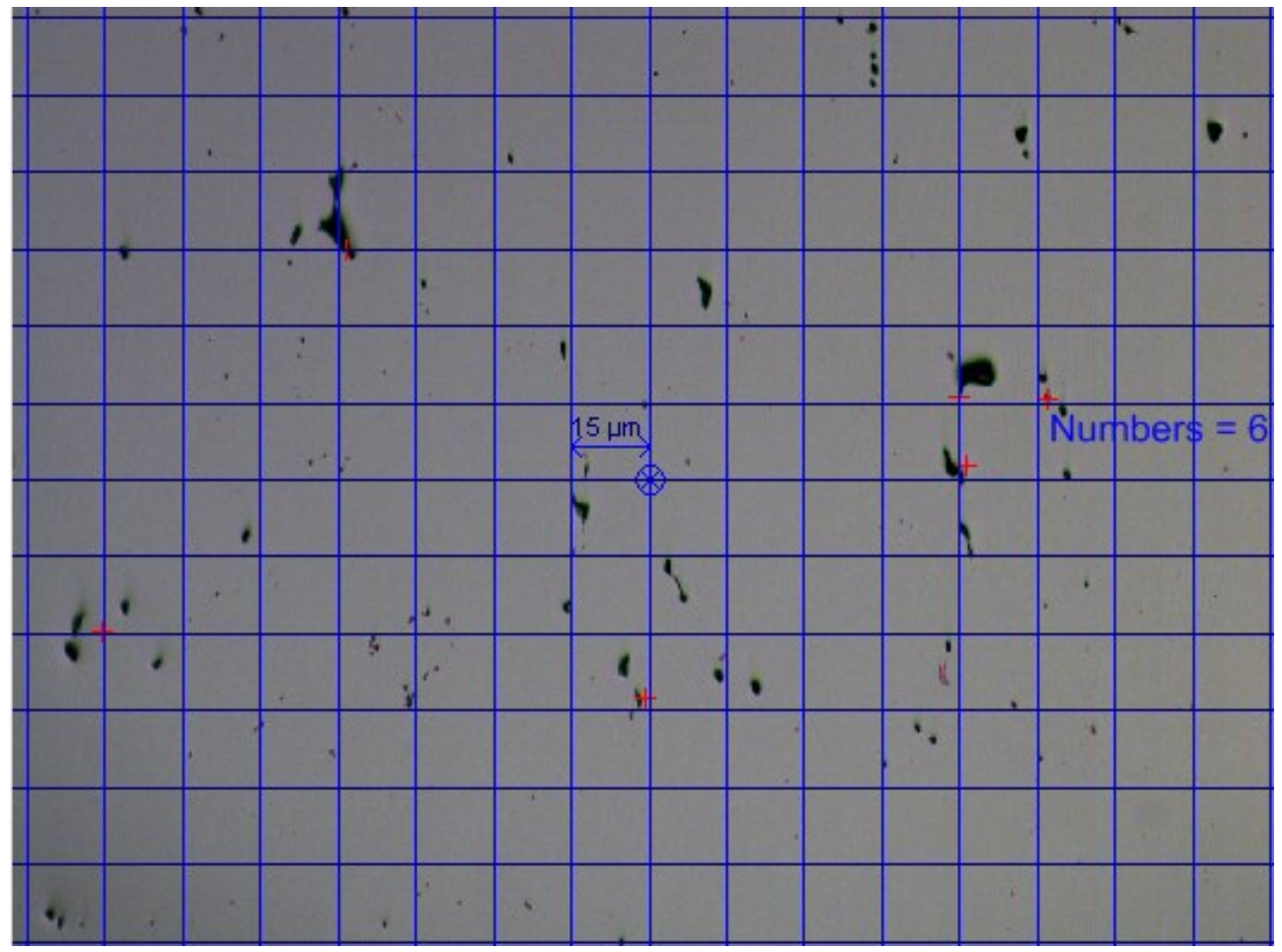

(b)

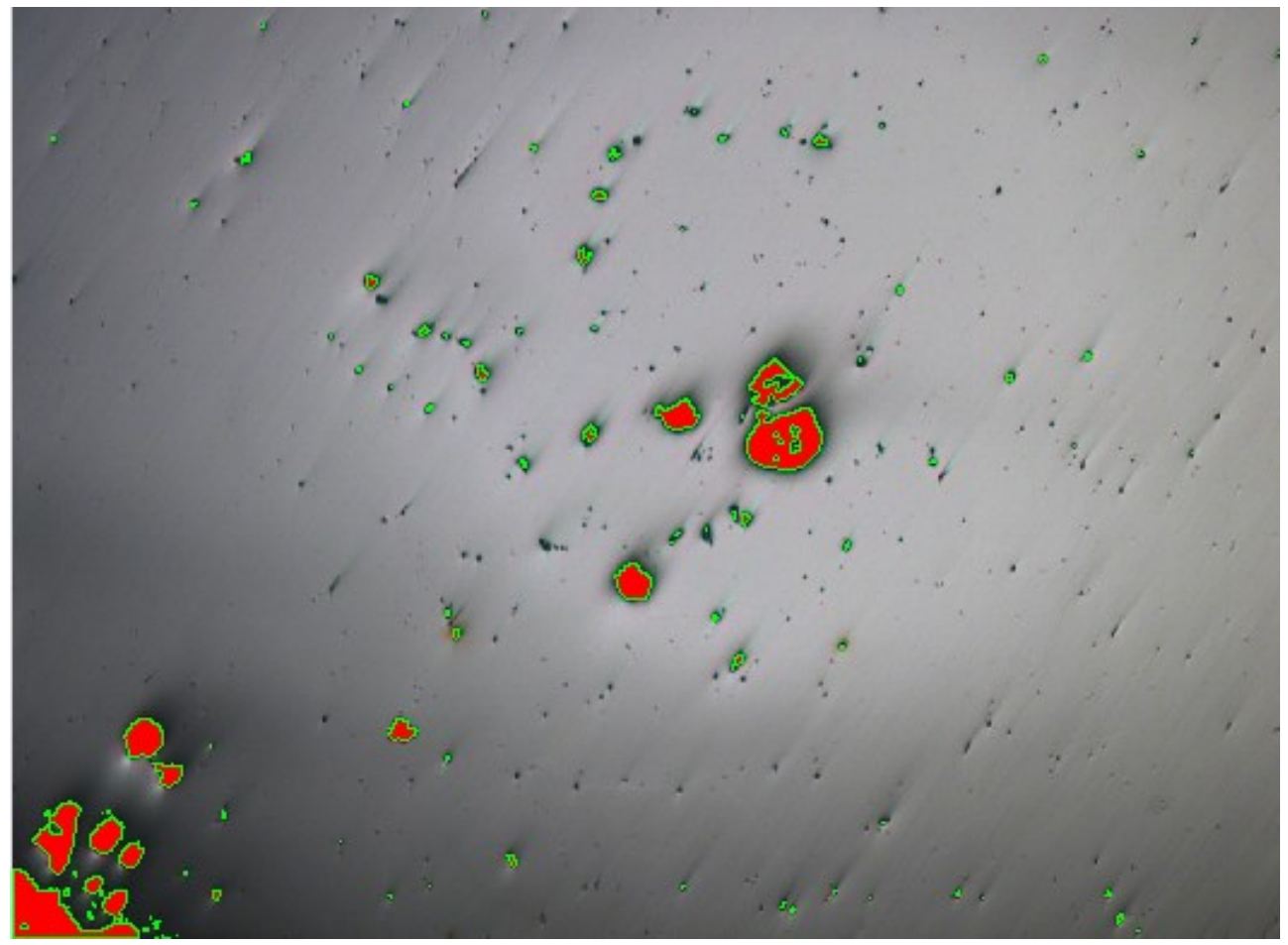




\subsubsection{Difração de elétrons retroespalhados (EBSD)}

A técnica de difração de elétrons retro-espalhados (electron back scattering diffraction) acoplada ao MEV foi usada para a caracterização microestrutural e cristalográfica dos grãos austeníticos do aço Hadfield refinado e sem refino, indicando a diferença de orientação cristalográfica entre os grãos e o tamanho dos grãos. No EBSD, a amostra com superfície perfeitamente plana e polida é colocada com inclinação de $70^{\circ}$ em relação ao feixe de elétrons incidente. Os átomos próximos à superfície interagem com o feixe de elétrons incidentes, promovendo choques (quase) elásticos que causam o espalhamento ou difração segundo a Lei de Bragg (OXFORD INSTRUMENTS, 2016).

Os elétrons retro-espalhados formam um par de cones, cuja intersecção com a tela de fosforo do sensor CCD geram um padrão de difração, que aparece na forma de linhas de Kikuchi (figura 34), podendo ser visualizada em um monitor de vídeo junto com a imagem de MEV do local de incidência do feixe. As linhas de Kikuchi fornecem informações cristalográficas da amostra policristalina (OXFORD INSTRUMENTS, 2016).

Figura 34 - Linhas de Kikuchi formadas pela difração dos elétrons retro-espalhados em amostra de níquel.

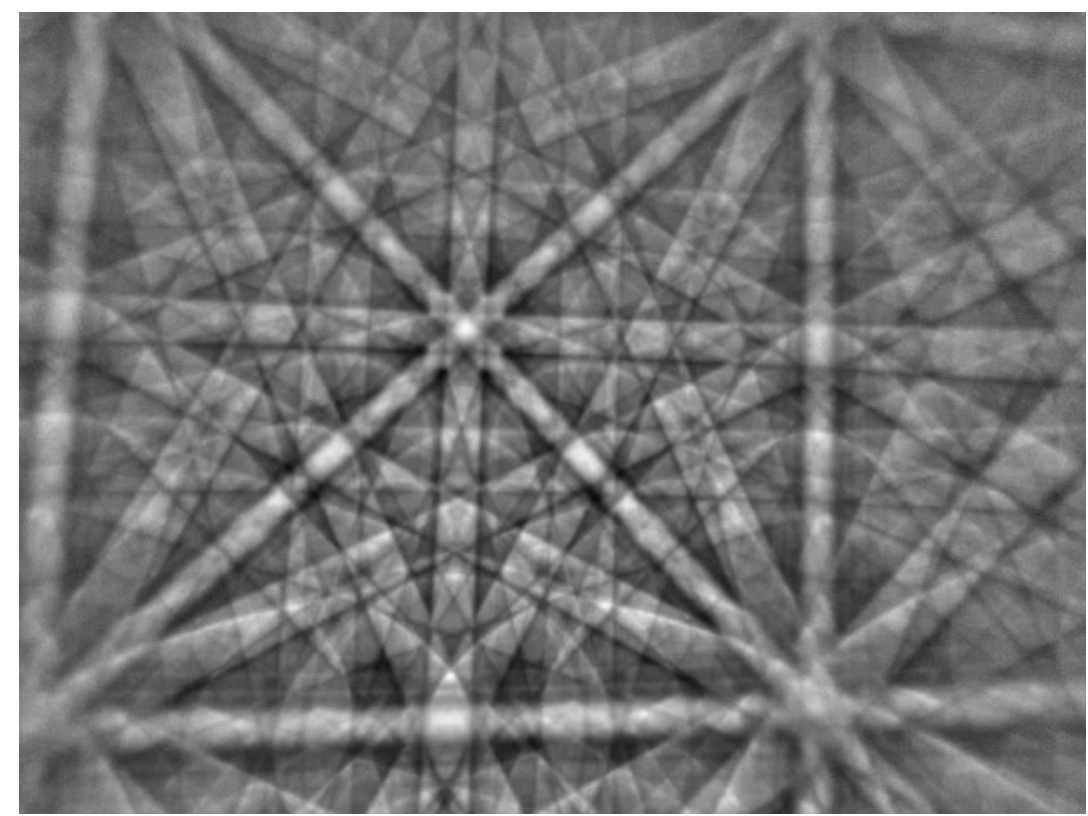

Fonte: Oxford instruments, 2016. 
O equipamento de EBSD é formado pela tela fluorescente que revela as linhas de Kikuchi, o sensor CCD (charge coupled device), o controlador de posicionamento, o controle eletrônico e a comunicação entre o EBSD / MEV, o amplificador e o processador de sinais, além do software para interpretação das linhas de Kikuchi, como indicados na figura 35 (OXFORD INSTRUMENTS, 2016).

Figura 35 - Equipamento da técnica de EBSD. (a) Componentes do equipamento de EBSD e (b) visão ampliada da câmara do MEV indicando a amostra inclinada a $70^{\circ}$ e a tela de fósforo.

(a)

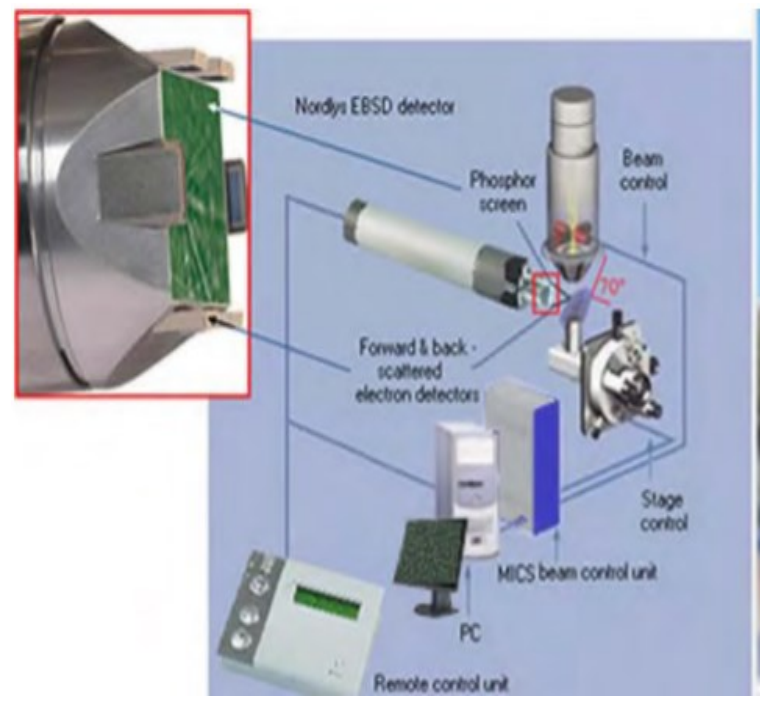

(b)

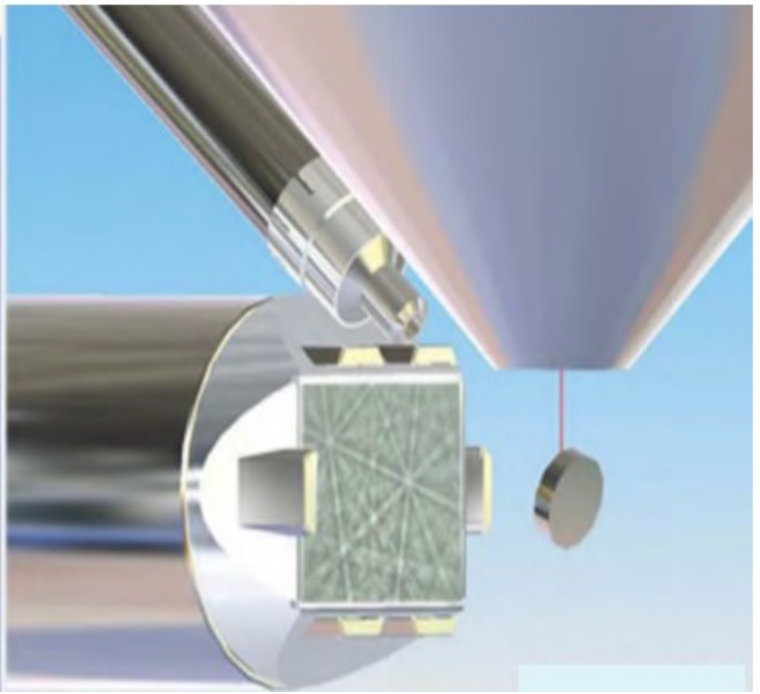

Fonte: Oxford instruments, 2016.

Os resultados do EBSD são baseados em um mapa de orientação com cores de referência no sistema RGB (vermelho-verde-azul), e representam a direção normal a superfície da amostra. Para cada orientação existe um plano e direção correspondente que são referenciados em uma projeção estereográfica (GOLDSTEIN, 2003). O código de orientação de cores é dado pelo triângulo da figura de polo invertida (IPF), sendo que as orientações cristalográficas de (001), (101) e (111) no sistema cúbico são representadas em vermelho, verde, e azul, respectivamente, como na figura 36 (OXFORD INSTRUMENTS, 2016). 
Figura 36 - Figura de polos invertida (IPF) para o sistema cúbico

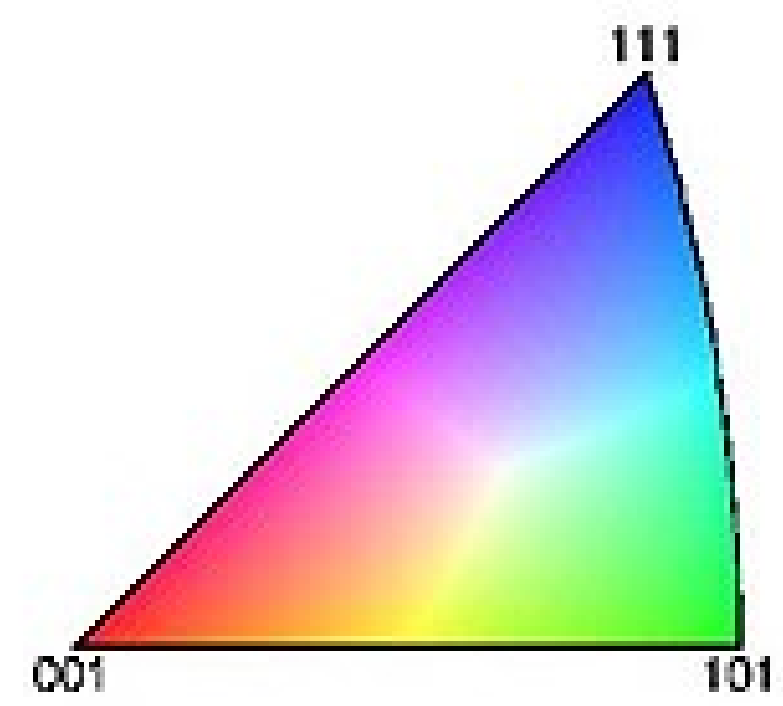

Fonte: Oxford instruments, 2016.

\subsection{USINAGEM DOS CORPOS DE PROVA PARA ENSAIOS MECÂNICOS}

Para a realização do ensaio mecânico de impacto foram usinados 3 corpos de prova por eletroerosão e para o ensaio de tração foram usinados 3 corpos de prova por torneamento. Na figura 37 tem-se a região de retirada dos corpos de prova para o ensaio de tração e impacto a partir do "keel block" (a) e para a segunda série do ensaio de impacto a partir do bloco (b). O corpo de prova para ensaio de impacto possui as dimensões de $55 \times 10 \times 10 \mathrm{~mm}$ segundo a norma ASTM E23 (figura 38) e o corpo de prova para o ensaio de tração segue a norma ASTM E8M (figura 39). 
Figura 37 - Figura esquemática da região de extração dos corpos de prova para o ensaio de tração e impacto (a) e para a segunda série do ensaio de impacto (b).

(a)

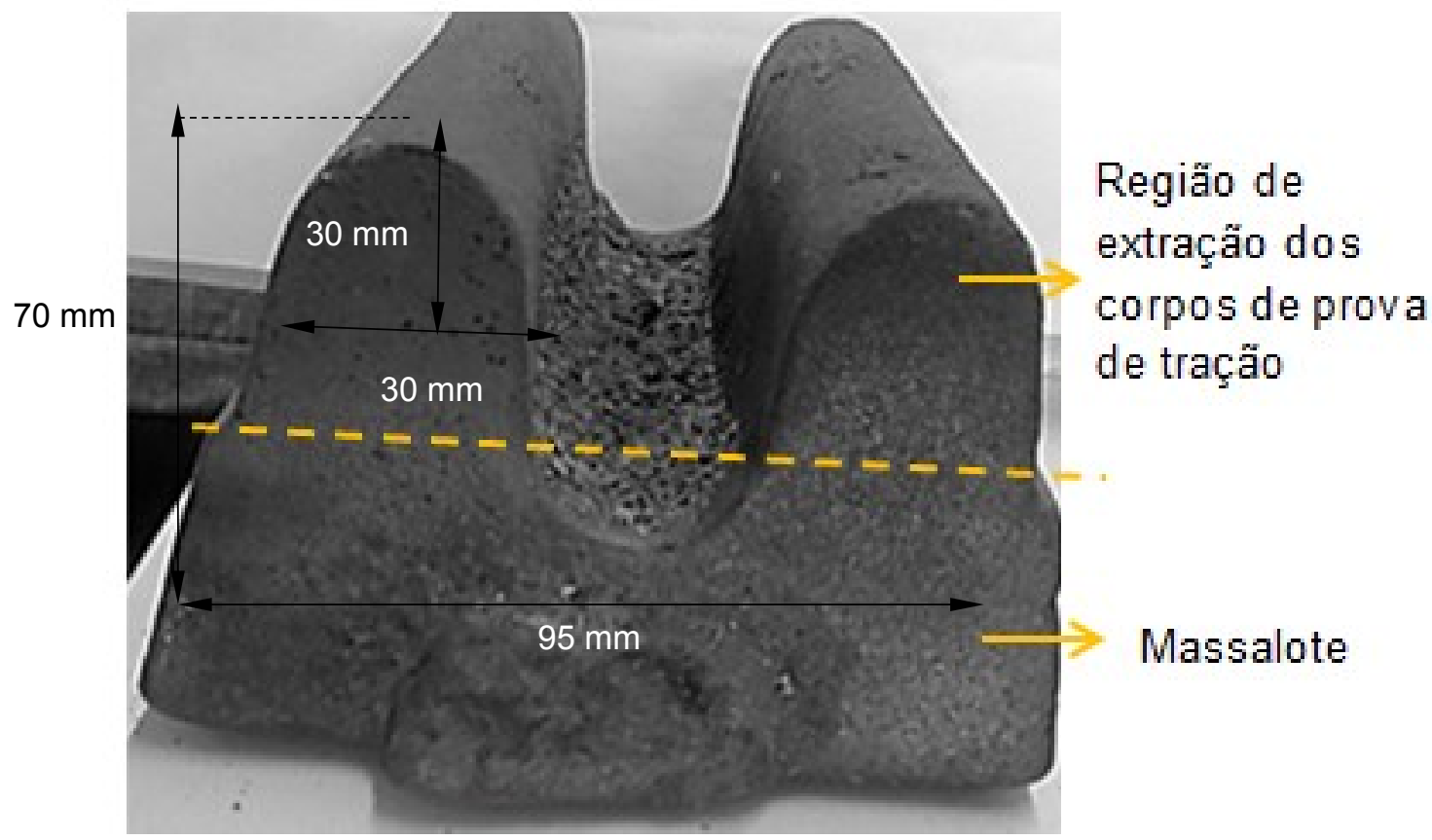

(b)

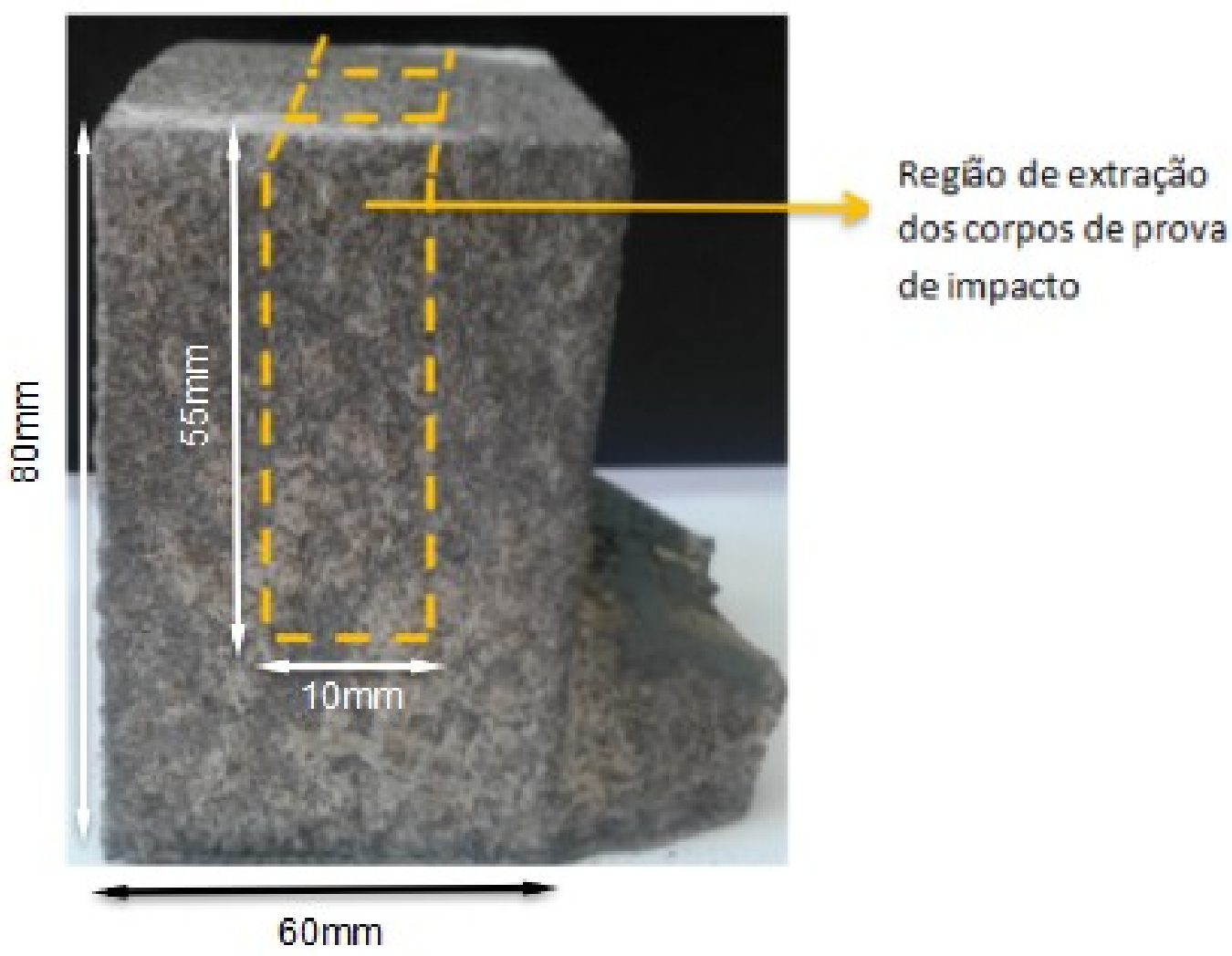


Figura 38 - Corpo de prova para ensaio de impacto com dimensões de $55 \times 10 \times 10$ mm segundo a norma ASTM E23.

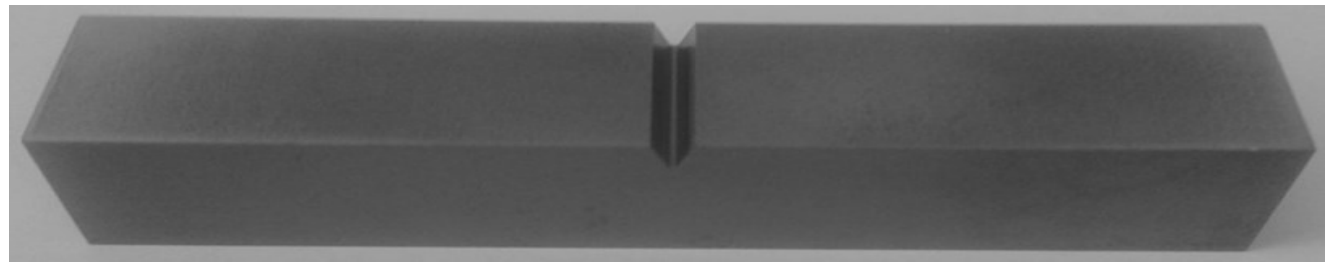

Figura 39 - Corpo de prova para ensaio de tração segundo a norma ASTM E8M.

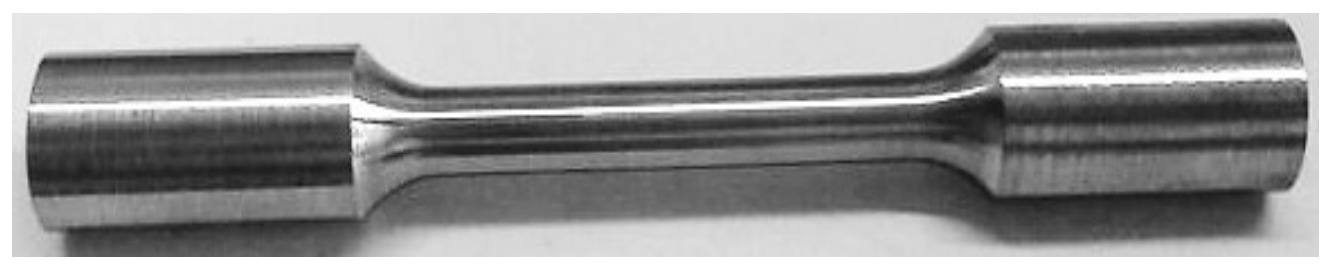

\subsection{ENSAIO DE IMPACTO CHARPY COM ENTALHE EM "V" DE AMOSTRAS SOLUBILIZADAS}

Os ensaios de impacto do tipo Charpy com entalhe em "V" foram realizados para três corpos de prova de amostras solubilizadas em cada condição investigada (aço Hadfield sem refino e refinado). Os ensaios foram realizados na máquina Wolpert PW 30/15 com carga de $294 \mathrm{~J}$ em temperatura ambiente (medida no dia do ensaio por termômetro em $20^{\circ} \mathrm{C}$ ). A máquina do ensaio de impacto foi calibrada pelo Centro de Metrologia Mecânica, Elétrica e de Fluidos (CTMNE) do IPT.

\subsection{ENSAIO DE TRAÇÃO DE AMOSTRAS SOLUBILIZADAS}

Os ensaios de tração monotônica axial foram realizados no equipamento MTS Sintec, utilizando o extensômetro EX-001, o micrômetro MC-006 e o paquímetro PQ-008, todos eles calibrados pelo Centro de Metrologia Mecânica, Elétrica e de Fluidos (CTMNE) do IPT. Os ensaios mecânicos foram realizados no CTMM do IPT, sendo parte do sistema de qualidade do IPT.

Os ensaios de tração foram realizados para três corpos de prova de amostras solubilizadas em cada condição (aço Hadfield sem refino e refinado) 
com dimensões reduzidas segundo a norma ASTM E8M. A taxa de deslocamento utilizada foi de $1 \mathrm{~mm} / \mathrm{min}$.

Foram obtidas as propriedades mecânicas de alongamento total (\%), resistência à tração, limite de escoamento e ruptura, e módulo de elasticidade a partir das curvas de tensão $x$ deformação.

\subsection{ENSAIOS FRACTOGRÁFICOS DOS CORPOS DE PROVA DE IMPACTO CHARPY E DO ENSAIO DE TRAÇÃO}

Os doze corpos de prova rompidos dos ensaios de tração e de impacto tiveram suas superfícies de fratura caracterizadas na lupa CITOVAL 2 e no microscópio eletrônico de varredura (MEV) Jeol JSM 6300 para relacionar as propriedades mecânicas obtidas com a fractografia e microestrutura dos corpos de prova. As superfícies de fratura dos corpos de prova rompidos no ensaio de tração também foram caracterizadas pela técnica EBSD. 


\section{RESULTADOS}

Os resultados serão apresentados na seguinte sequência:

- Simulações microestruturais do caminho de solidificação usando o software Thermo-Calc;

- Caracterização macro e microestrutural das amostras fundidas e das amostras solubilizadas das condições sem refino do grão austenítico e com refino do grão austenítico com Hf;

- Resultados dos ensaios de tração dos corpos de prova solubilizados das condições sem refino do grão austenítico e com refino do grão austenítico e suas respectivas fractografias;

- Resultados dos ensaios de impacto dos corpos de prova solubilizados das condições sem refino do grão austenítico e com refino do grão austenítico e suas respectivas fractografias.

As composições químicas das amostras investigadas de aço Hadfield estão de acordo com as especificações químicas descritas na norma ASTM A128, grau B-2 (vide na tabela 6).

\subsection{SIMULAÇÕES MICROESTRUTURAIS DE SOLIDIFICAÇÃO USANDO O SOFTWARE THERMO-CALC}

Foram realizadas simulações no Thermo-Calc para caracterizar as temperaturas das transformações de fase durante a solidificação e a evolução microestrutural do aço Hadfield grau B2 da norma ASTM A128 com a composição química de interesse ( $13 \%$ de $\mathrm{Mn}, 0,65 \%$ de Si e $1,2 \%$ de $\mathrm{C}$ ). A figura 40 mostra a fração em massa dos componentes da fase liquida em função da temperatura no modelo de Scheil. Observa-se que a temperatura liquidus é de $1378^{\circ} \mathrm{C}$, ou seja, a temperatura na qual inicia-se a formação da fase austenita, e com o resfriamento até $1090^{\circ} \mathrm{C}$ ocorre a formação da fase cementita. 
Figura 40 - Fração em massa do liquido em função da temperatura considerando-se o modelo de Scheil.

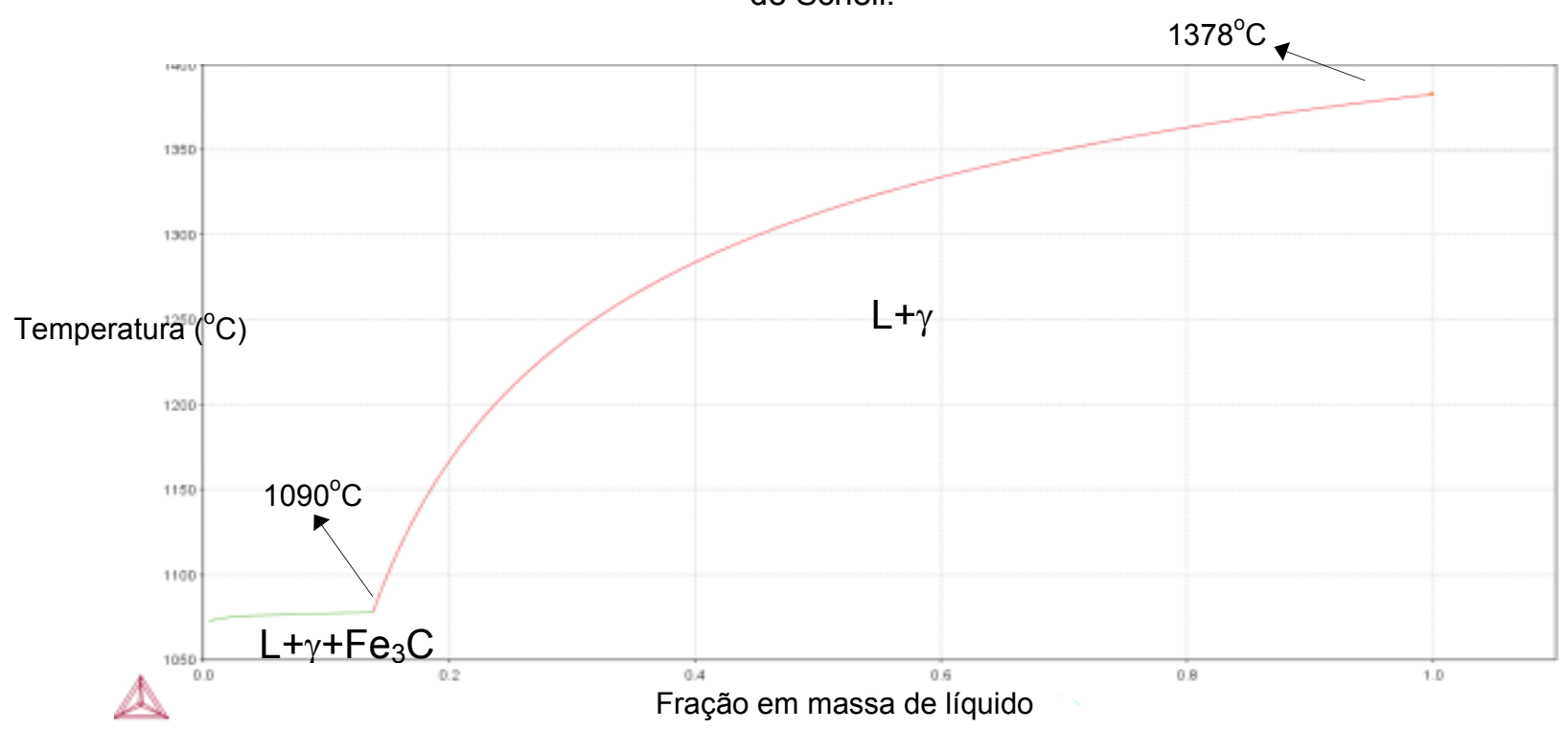

A figura 41 mostra a fração molar de sólidos (fases austenita e cementita) durante a solidificação do aço Hadfield grau B2 da norma ASTM A128 com a composição química de interesse (13\% de $\mathrm{Mn}, 0,65 \%$ de Si e $1,2 \%$ de C) fora do equilíbrio - com redistribuição de soluto por mistura completa (modelo de Scheil) - em comparação com a solidificação no equilíbrio. Observa-se com a diminuição da temperatura que a curva do resfriamento baseada no modelo de Scheil se afasta cada vez mais da curva de solidificação em condições de equilíbrio.

Figura 41 - Fração molar de sólido considerando-se a solidificação pelo modelo de Scheil. A condição de solidificação de equilíbrio é mostrada pela linha pontilhada.

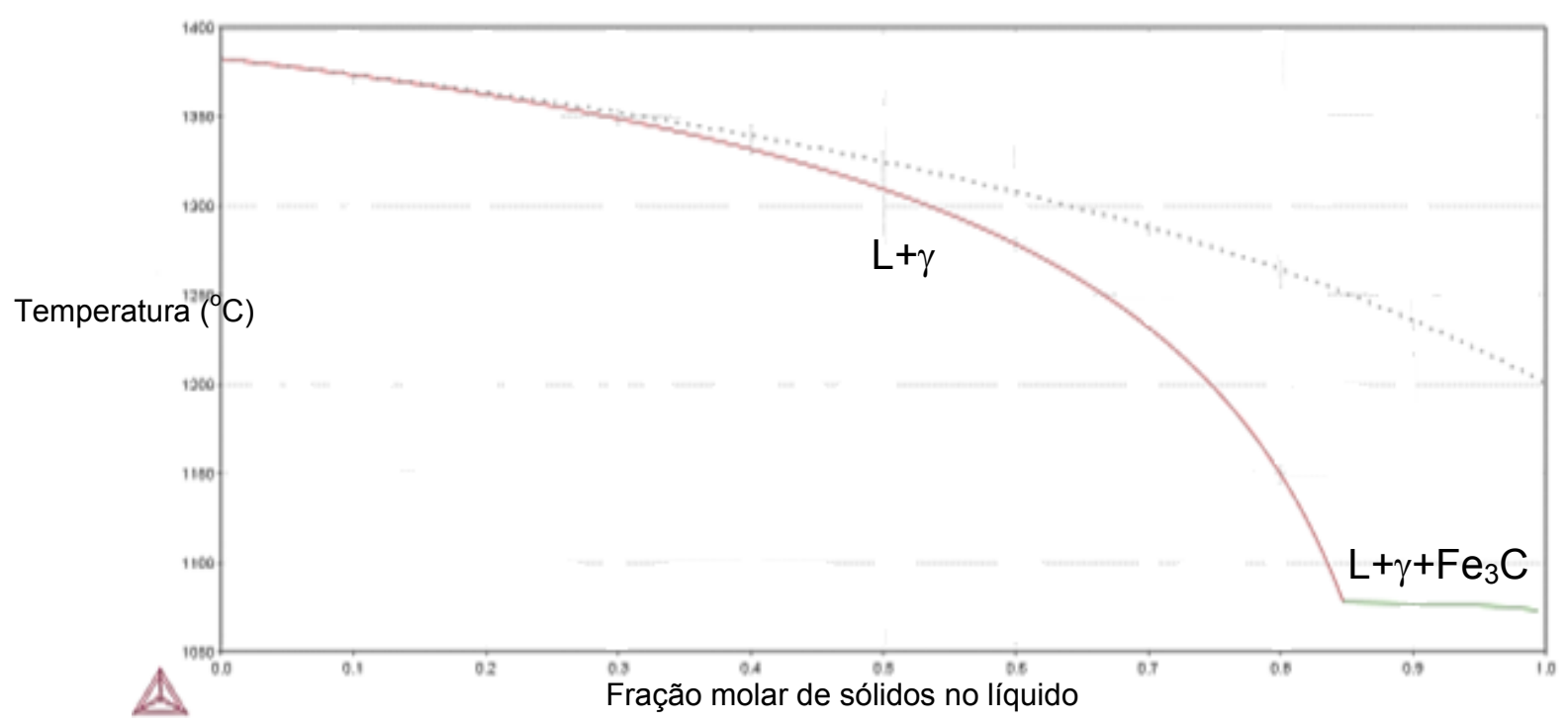


A figura 42 mostra o gráfico da redistribuição de soluto (Mn, C e Si) na fase liquido do aço Hadfield grau B2 da norma ASTM A128 com a composição química de interesse (13\% de $\mathrm{Mn}, 0,65 \%$ de $\mathrm{Si}$ e 1,2\% de C). Observa-se que, em termos relativos, o $\mathrm{C}$ é o elemento que mais particiona para o estado liquido durante a solidificação (sai de $1,2 \%$ e chega a $4 \%$ na fase líquida a $1050^{\circ} \mathrm{C}$ ), seguido pelo $\mathrm{Mn}$ (sai de $13 \%$ e chega a $21 \%$ na fase líquida a $1050^{\circ} \mathrm{C}$ ), e em contraste, o Si possui partição inversa durante a solidificação (sai de $0,65 \%$ e chega a valores abaixo de $0,3 \%$ na fase líquida a $1050^{\circ} \mathrm{C}$ ).

Figura 42 - Redistribuição dos solutos (Mn, C e Si) na fase líquida considerando-se o modelo de solidificação de Scheil.

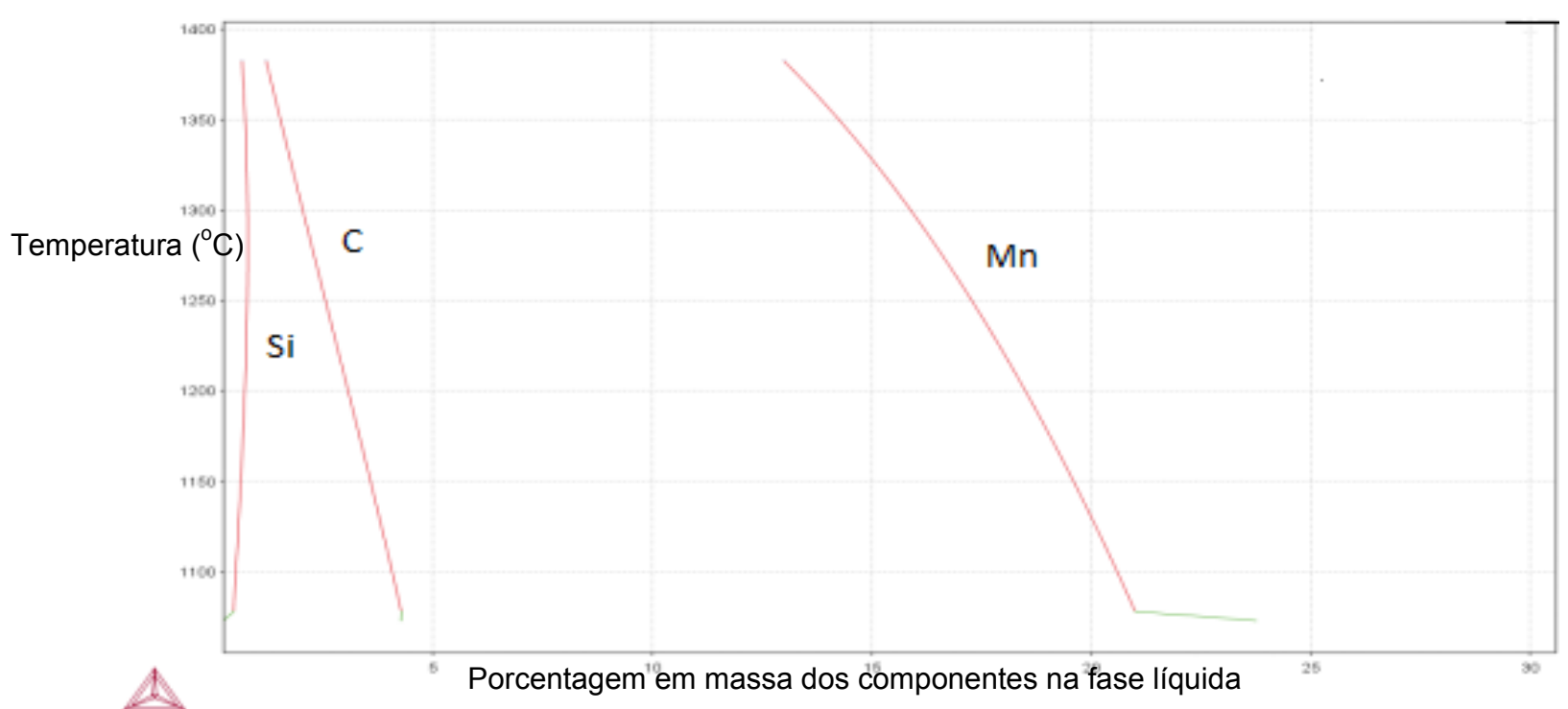

A simulação da sequência de solidificação no equilíbrio do aço Hadfield grau B2 da norma ASTM A128 com a composição química de interesse (13\% de $\mathrm{Mn}, 0,65 \%$ de Si e 1,2\% de C) - condição sem refino - pode ser observada no diagrama da fração volumétrica das fases presentes em função da temperatura (figura 43). O intervalo de solidificação para a composição química analisada é de $179^{\circ} \mathrm{C}$ e a temperatura liquidus é de $1378^{\circ} \mathrm{C}$. Com o resfriamento durante a solidificação, a fase austenita é presente para temperaturas logo abaixo de $1200^{\circ} \mathrm{C}$. A partir de $900^{\circ} \mathrm{C}$, inicia-se a precipitação 
de cementita. A partir de $580^{\circ} \mathrm{C}$ observa-se a formação de perlita (lamelas de ferrita e cementita) e a precipitação de carbonetos do tipo $\mathrm{M}_{5} \mathrm{C}_{2}$.

Figura 43 - Fração volumétrica das fases $\mathrm{M}_{5} \mathrm{C}_{2}$, ferrita, cementita, austenita e liquido em função da temperatura $\left({ }^{\circ} \mathrm{C}\right)$.

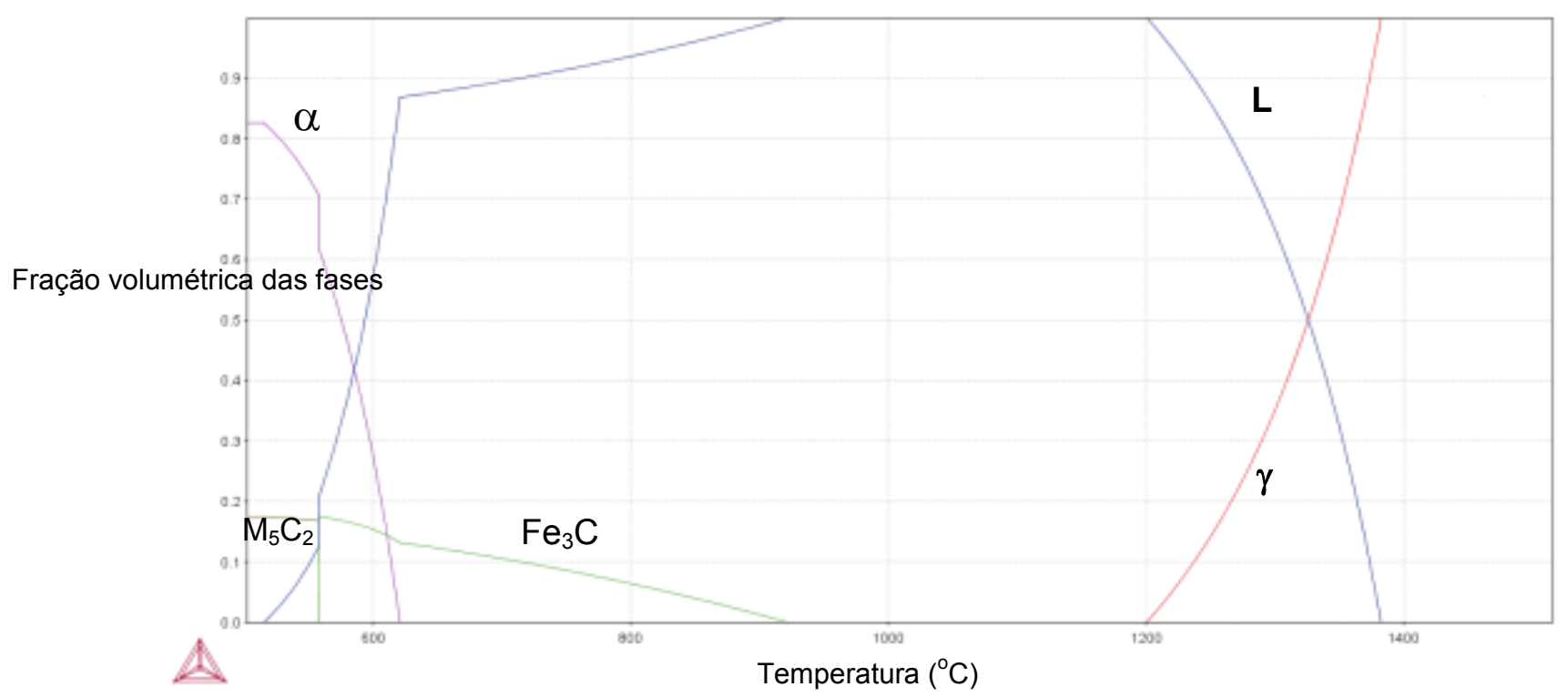

A simulação da sequência de solidificação no equilíbrio do aço Hadfield com a adição de $0,1 \% \mathrm{Hf}$ - condição com refino - é mostrada no diagrama da fração volumétrica das fases presentes em função da temperatura (figuras 44-a a 44-c). Observa-se à temperatura de $1472^{\circ} \mathrm{C}$ a precipitação de uma fase sólida rica em Hf (com estrutura cristalina do tipo CFC) a partir da fase líquido, sugerindo que os precipitados desta fase "hipotética" poderiam atuar como sítios preferenciais para a nucleação heterogênea da austenita durante a solidificação. Observe que a temperatura de formação da austenita na solidificação é de $1378^{\circ} \mathrm{C}$, quase $100^{\circ} \mathrm{C}$ abaixo da temperatura de formação da fase rica em $\mathrm{Hf}$. $\mathrm{O}$ háfnio tende a formar compostos inorgânicos com o oxigênio, nitrogênio, enxofre, boro e carbono (NIELSEN, 2000) e considerando a composição química do aço Hadfield e a estrutura cristalina da fase rica em $\mathrm{Hf}$ do tipo CFC, sugere-se que a fase rica em $\mathrm{Hf}$ é um carboneto de háfnio. Esta observação decorrente da simulação deverá ser examinada com mais detalhe durante a caracterização microestrutural das amostras fundidas contendo $\mathrm{Hf}$. 
Figura 44 - Evolução microestrutural, segundo o modelo de Scheil, do aço Hadfield com adição de Hf. (a) Fração em massa das fases $\mathrm{M}_{7} \mathrm{C}_{3}, \mathrm{M}_{5} \mathrm{C}_{2}$, ferrita, cementita, austenita e líquido em função da temperatura $\left({ }^{\circ} \mathrm{C}\right)$; (b) Detalhe da formação de fase rica em $\mathrm{Hf}$ em temperatura de $1472^{\circ} \mathrm{C}$;(c) Gráfico indicando a fração em massa do Hf presente no líquido, cementita, ferrita, $\mathrm{M}_{7} \mathrm{C}_{3}, \mathrm{M}_{5} \mathrm{C}_{2}$, austenita, e uma segunda fase CFC em função da temperatura.

(a)

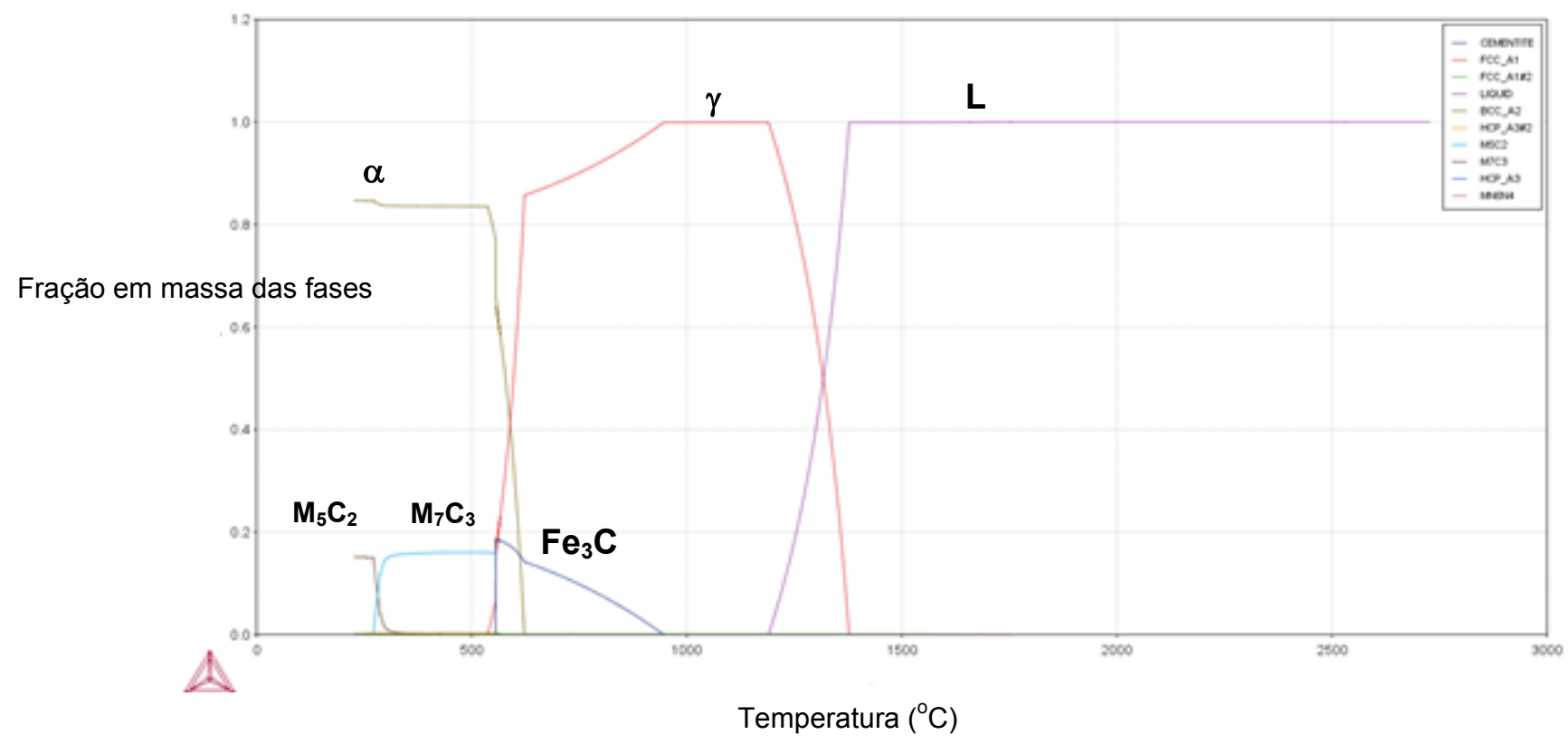

(b)

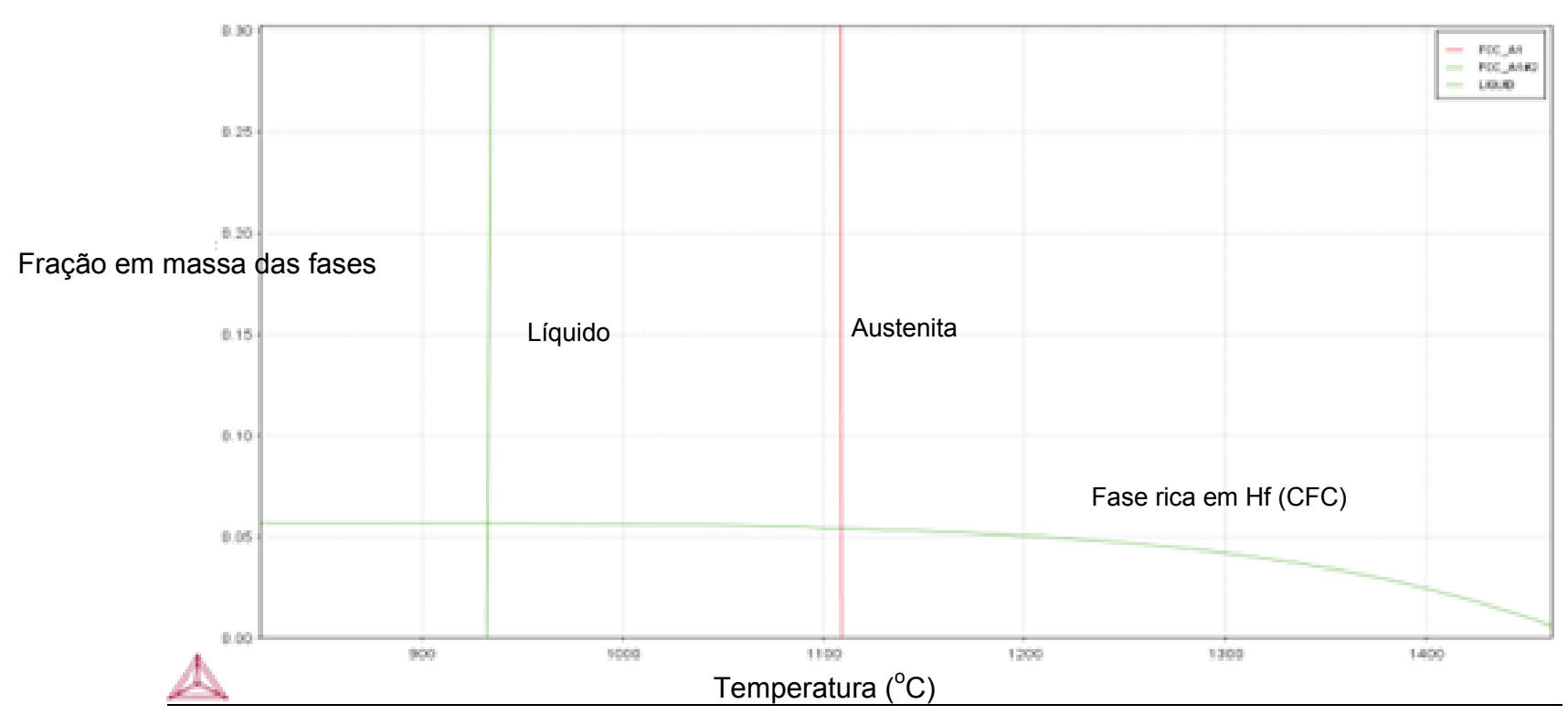


(c)

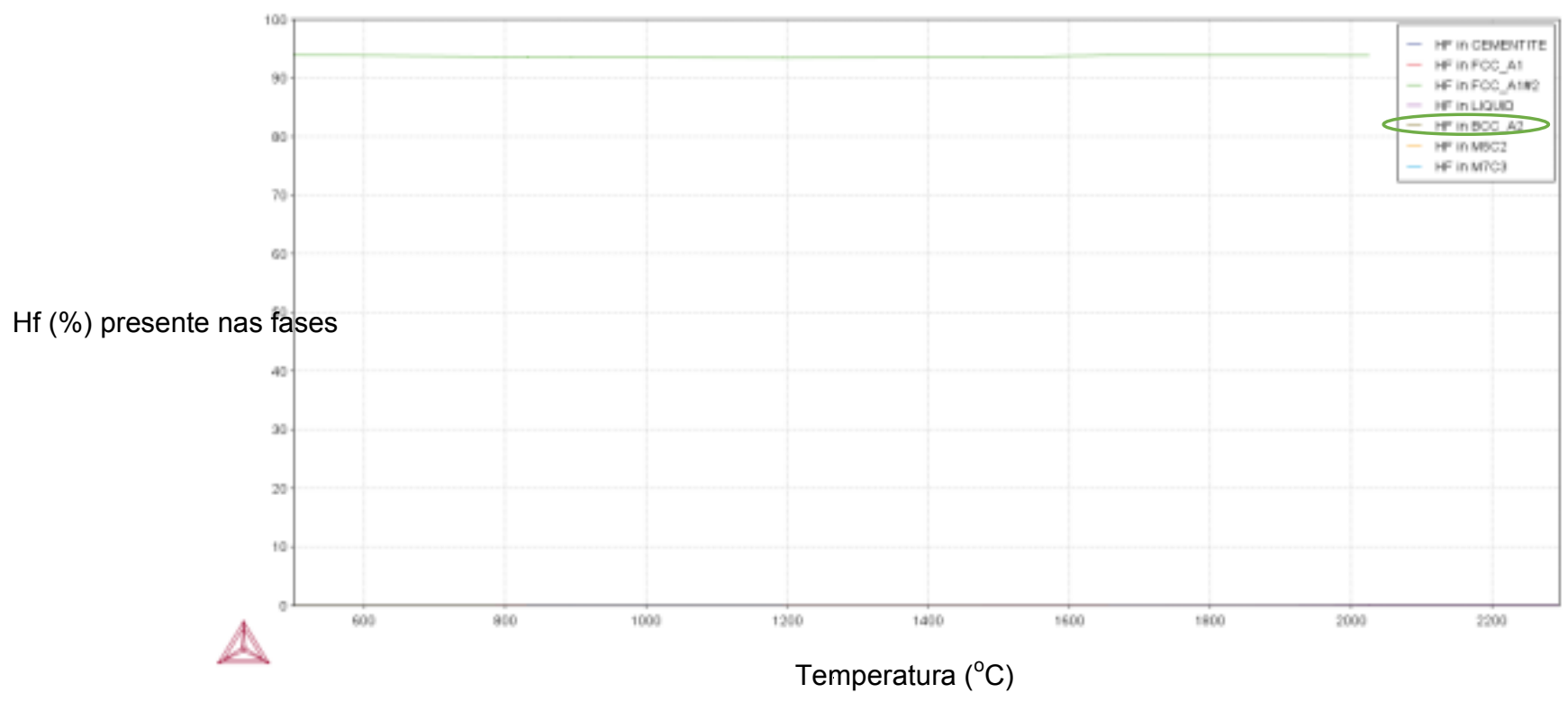


5.2 CARACTERIZAÇÃO MACRO E MICROESTRUTURAL DAS AMOSTRAS FUNDIDAS E DAS AMOSTRAS SOLUBILIZADAS: COMPARAÇÃO DA CONDIÇÃO SEM REFINO COM A CONDIÇÃO REFINADA.

As figuras 45-a e 46-a mostram as macrografias do aço Hadfield da condição sem refino em comparação com o aço Hadfield refinado com $\mathrm{Hf}$ (figuras 45-b e 46-b). $O$ aço Hadfield na condição sem refino apresenta três zonas macroestruturais de solidificação devido às diferenças na taxa de resfriamento do fundido: zona coquilhada, próxima a superfície; zona colunar (figura 45-a) e zona equiaxial (figura 46-a) na região central da peça. A zona coquilhada possui $2 \mathrm{~mm}$ de comprimento e não considerada para as medidas de tamanho de grão. A zona colunar possui $15 \mathrm{~mm}$ de largura na direção da superfície para o centro da peça e a zona equiaxial possui aproximadamente $40 \mathrm{~mm}$ de extensão na região central da peça. O comprimento dos grãos colunares é de aproximadamente $4000 \mu \mathrm{m}$ e o tamanho dos grãos equiaxiais é de $3000 \mu \mathrm{m}$.

As figuras 45-b e 46-b mostram a macrografia do aço Hadfield da condição refinada com $0,1 \% \mathrm{Hf}$. Observa-se para a condição refinada que a macroestrutura do corpo de prova não possui as zonas coquilhada e colunar bem definidas, sugerindo que as adições de $\mathrm{Hf}$ promoveram uma distribuição uniforme dos sítios para a nucleação heterogênea da austenita durante a solidificação. Observa-se ainda uma distribuição uniforme e homogênea de grãos equiaxiais, com tamanho aproximado de $600 \mu \mathrm{m}$, que é mais refinado do que da condição anterior. 
Figura 45 - Comparação entre (a) zona coquilhada e colunar do aço Hadfield sem refino e (b) região próxima à superfície do aço Hadfield refinado. Aumento original de 7,3x. Ataque químico: Nital 6\%. Exame em lupa.

(a)

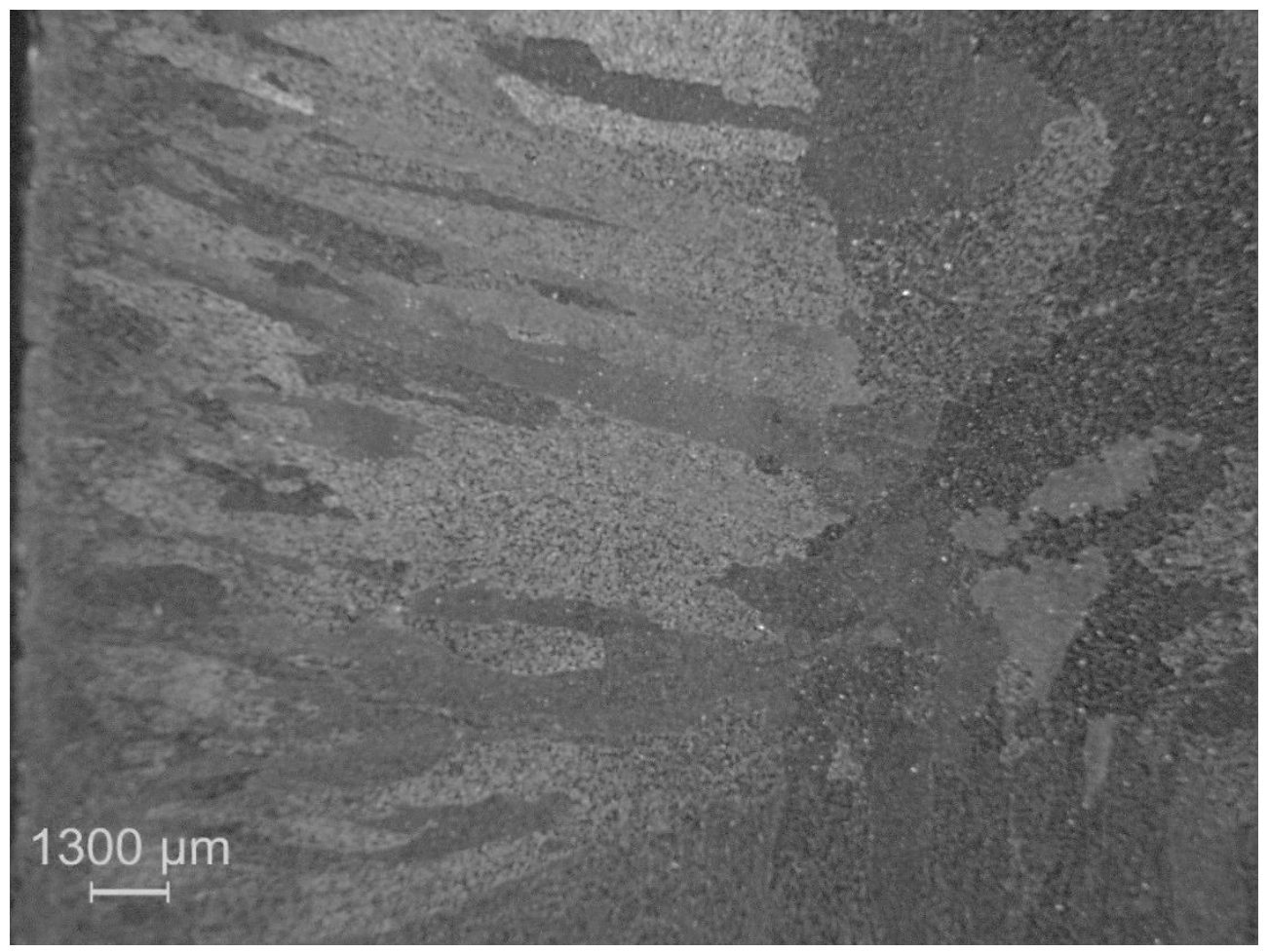

(b)

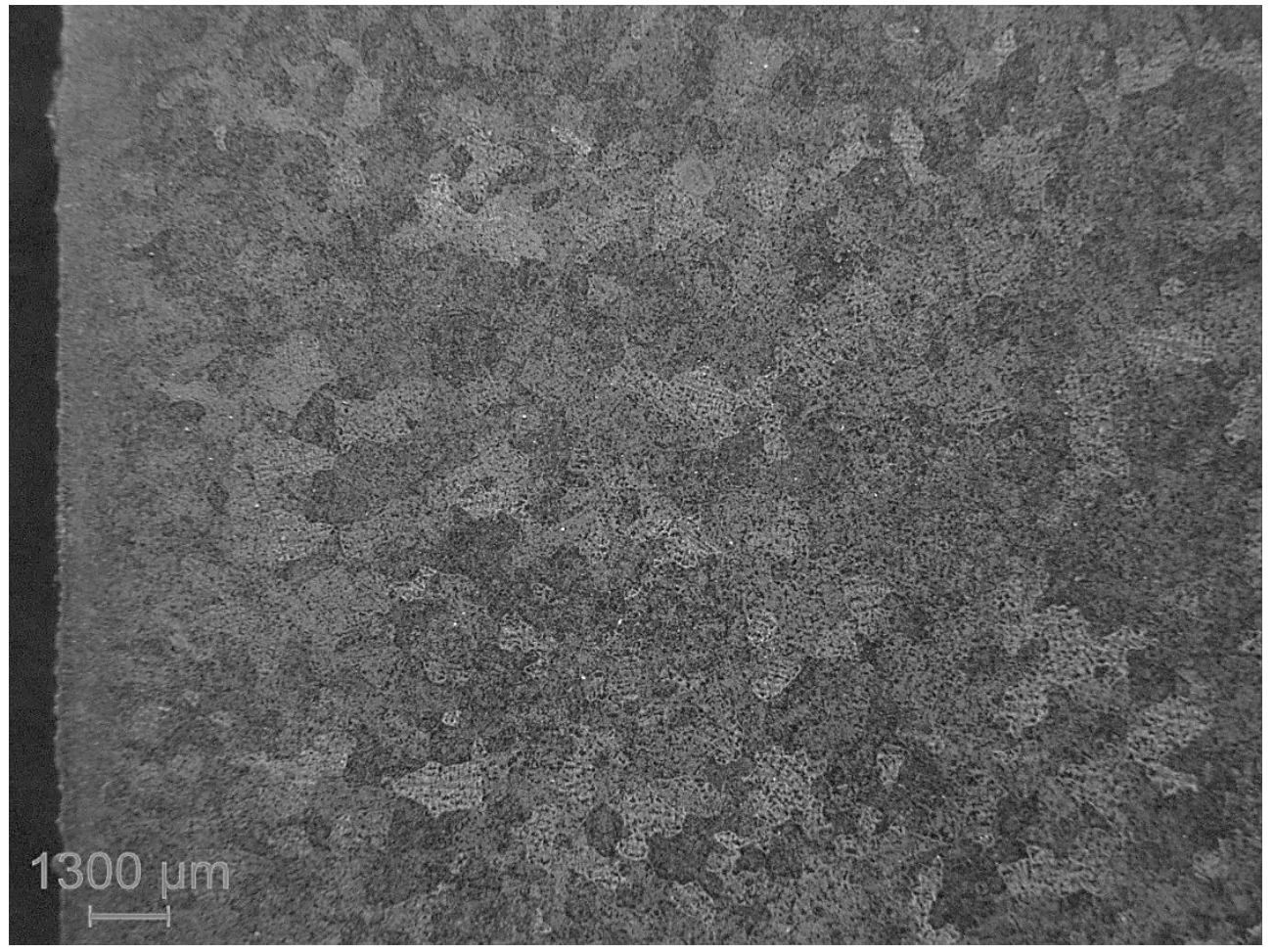


Figura 46 - Comparação entre (a) região equiaxial do aço Hadfield sem refino e (b) região central do aço Hadfield refinado. Aumento original de 7,3x. Ataque químico: Nital 6\%. Exame em lupa.

(a)

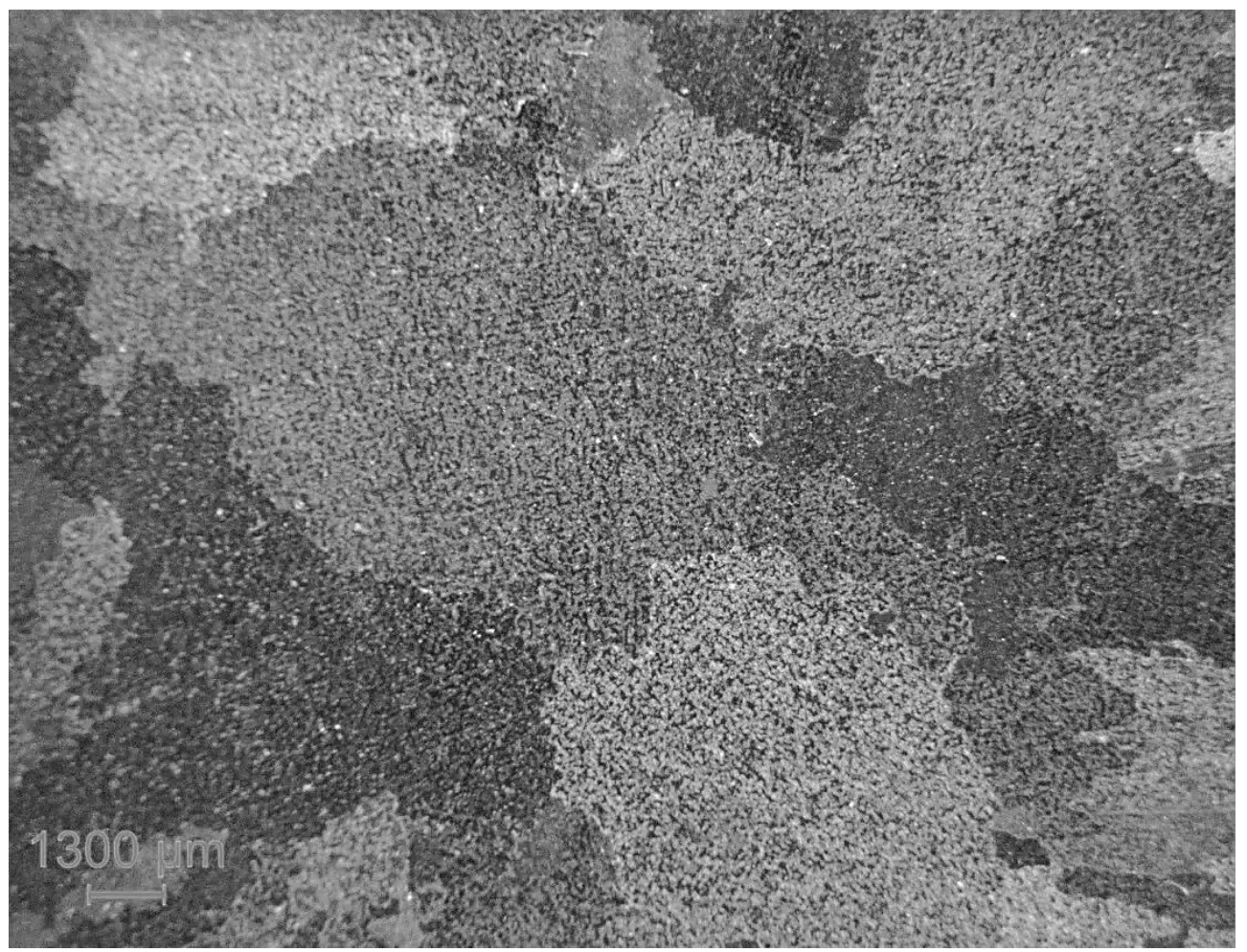

(b)

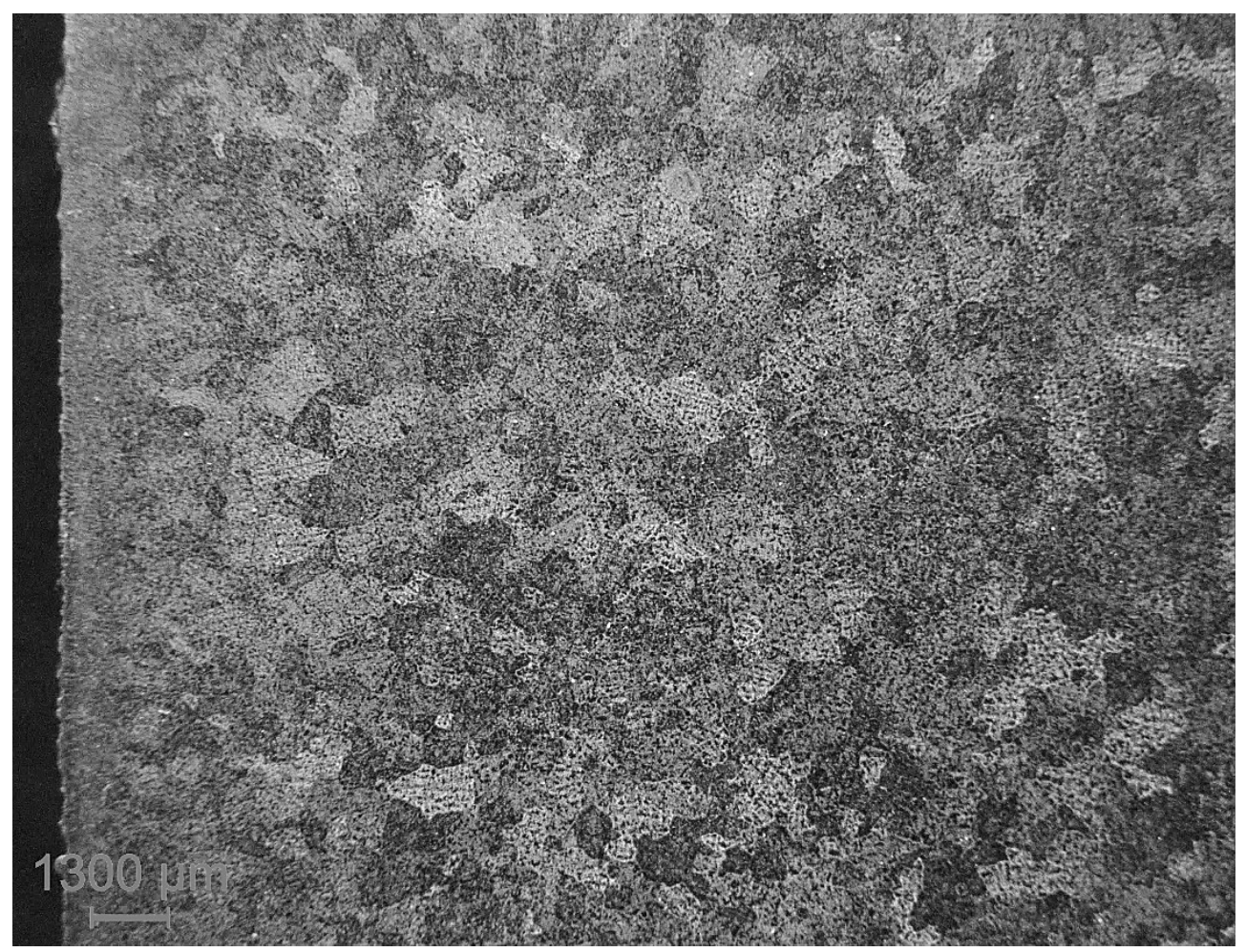


As figuras 47 e 48 mostram as microestruturas das condições sem refino e refinada após o tratamento térmico de solubilização realizado à temperatura de $1120^{\circ} \mathrm{C}$ por tempo de 10 horas. Observa-se para as duas condições a presença de matriz - austenítica - com contornos de grãos pouco nítidos após o ataque químico com Nital. A microestrutura também possui rechupes de aproximadamente $50 \mu \mathrm{m}$ de diâmetro e a presença de inclusões de 1-2 $\mu \mathrm{m}$ de diâmetro (vide figura 49-a), principalmente inclusões não metálicas de sulfeto de manganês (MnS) conforme espectro da microanálise química EDS da figura 49-b. Segundo a literatura (LIMA, 2011) são formadas inclusões não metálicas de sulfeto de manganês (MnS) no aço Hadfield. A fração volumétrica de inclusões foi determinada como sendo de $3,2 \%$ para o aço Hadfield sem refino e de $3,6 \%$ para o aço Hadfield refinado. 
Figura 47 - Aço Hadfield sem refino após tratamento térmico de solubilização à $1120^{\circ} \mathrm{C}$ por 10 horas. Aumento original de 50x. Ataque químico: Nital 3\%. Microscópio óptico.

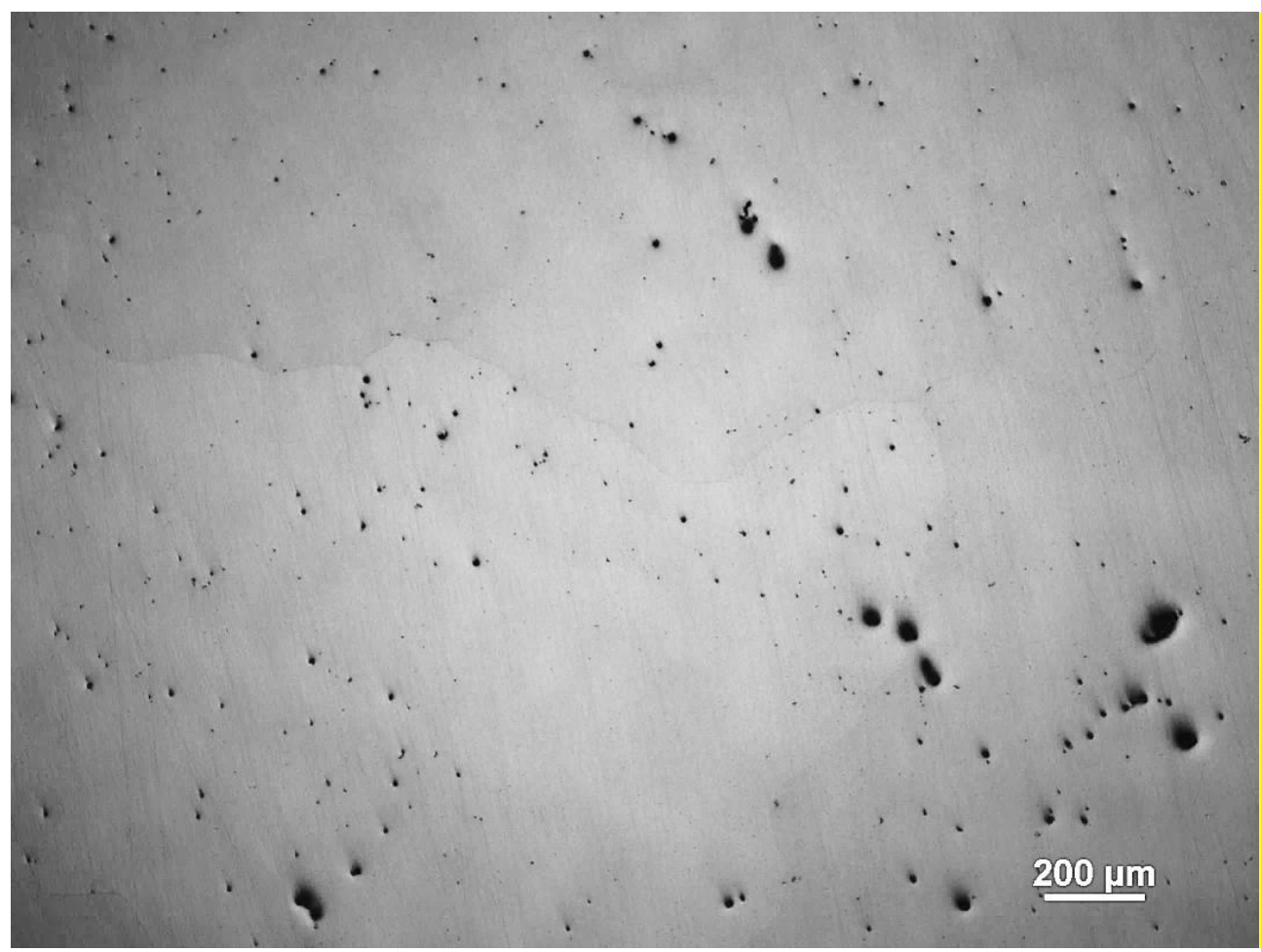

Figura 48 - Aço Hadfield refinado com $0,1 \% \mathrm{Hf}$ após tratamento térmico de solubilização à $1120^{\circ} \mathrm{C}$ por 10 horas. Aumento original de 50x. Ataque químico: Nital 3\%. Microscópio óptico.

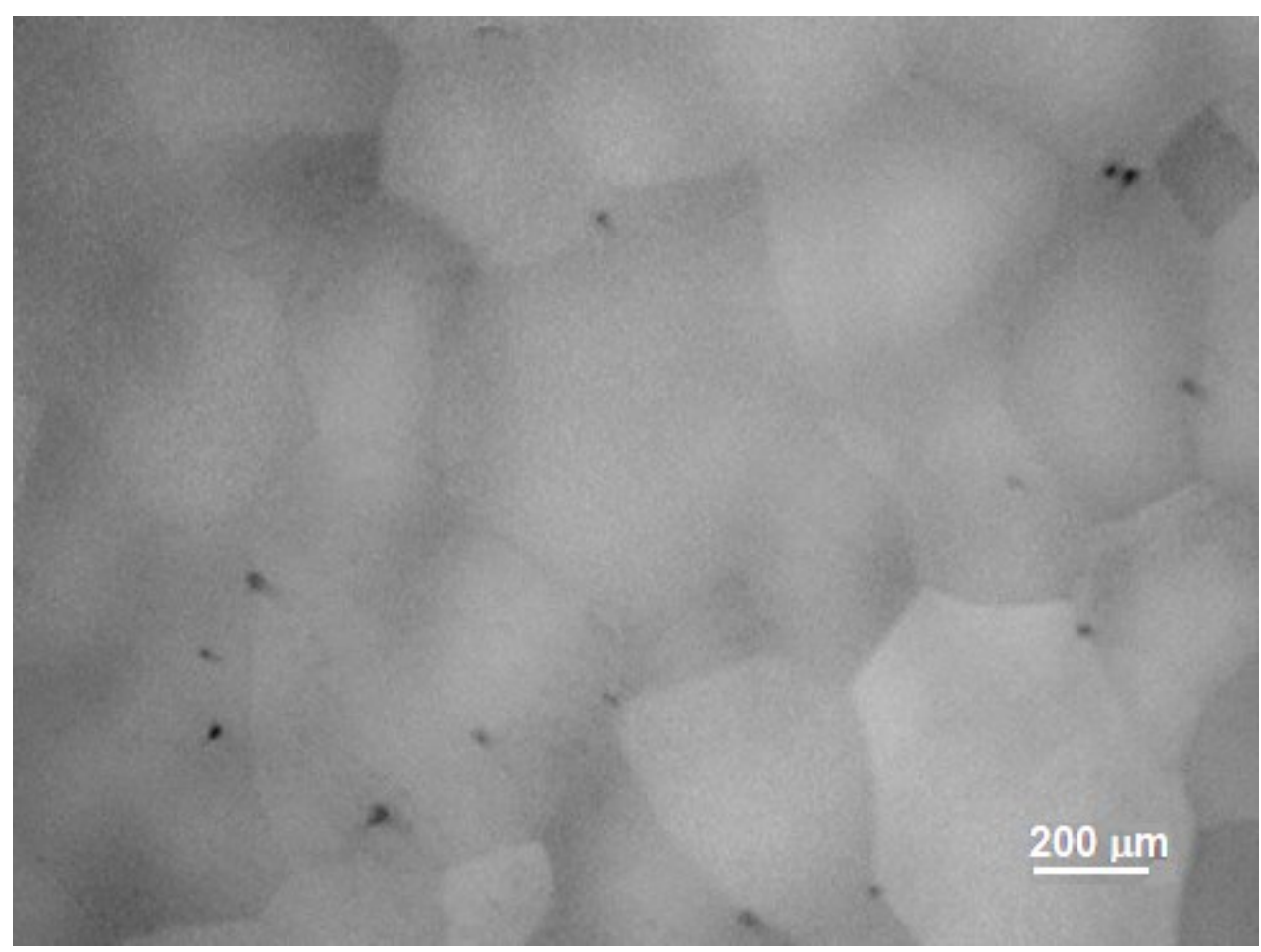


Figura 49 - Resultados de EDS das partículas presentes na microestrutura do aço Hadfield sem refino. (a) Imagem de MEV da partícula na qual a análise de EDS foi realizada; (b) Espectro de microanálise EDS desta partícula. $\mu$

(a)

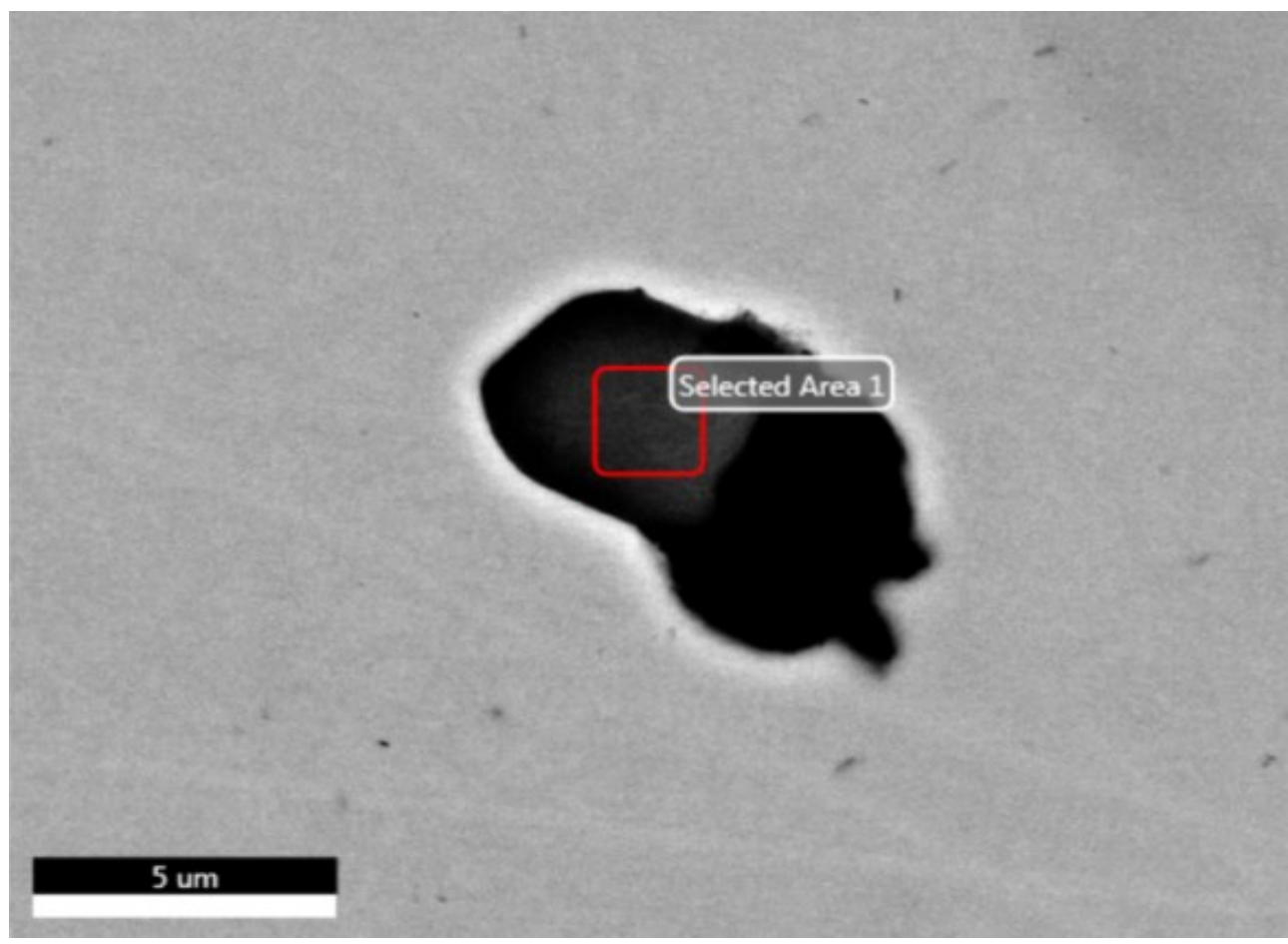

(b)

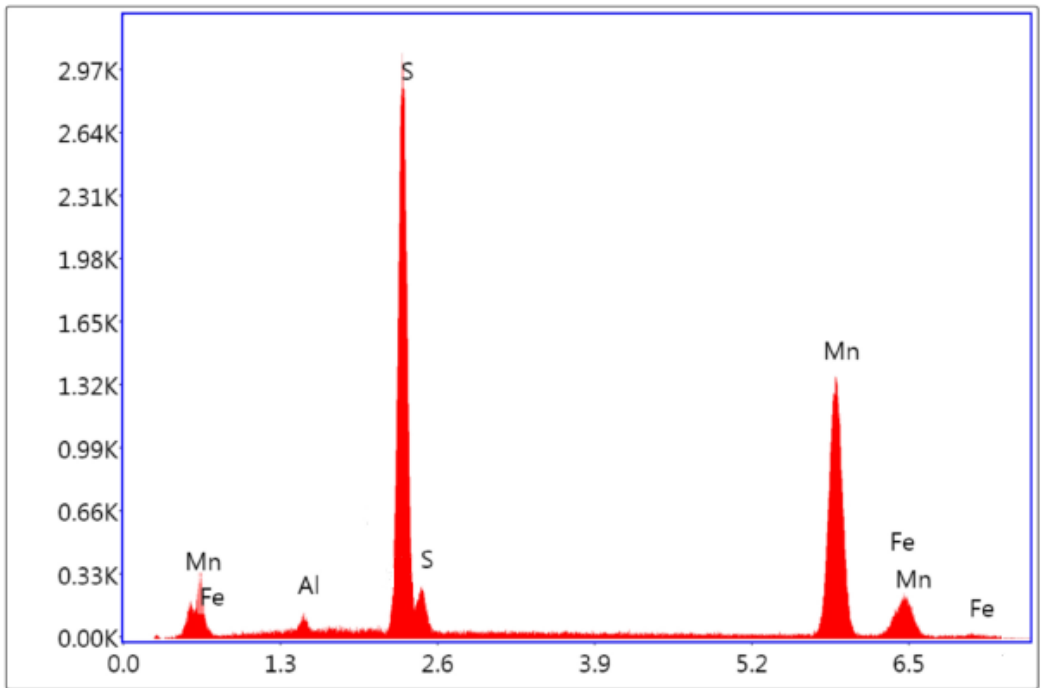

\begin{tabular}{|c|c|}
\hline Elemento & $\mathbf{W t} \%$ \\
\hline $\mathrm{Fe}$ & 4 \\
\hline $\mathrm{Mn}$ & 47 \\
\hline $\mathrm{S}$ & 48 \\
\hline $\mathrm{Al}$ & 1 \\
\hline
\end{tabular}


A técnica de EBSD foi utilizada para confirmar o refino do tamanho de grão austenítico na amostra refinada com $0,1 \% \mathrm{Hf}$ na condição solubilizada observados nas macrografias (figuras 45-b e 46-b) e micrografias (vide figuras 47 e 48) mostradas anteriormente.

Observa-se na figura 50-a que os grãos da região colunar do aço Hadfield sem refino após solubilização possuem aparentemente uma orientação preferencial em torno de [100] e [311] (figura 50-b). Adicionalmente, o exame dos grãos equiaxiais da região central do aço Hadfield sem refino após o tratamento de solubilização (figura 51-a) indica a presença de uma pequena desorientação cristalográfica dentro de um grão de austenita, com uma orientação preferencial em torno de [321], como mostrado na figura de polo inversa (figura 51-b), indicando a possível presença de contornos de subgrãos (subgrãos da ordem de 1500-2000 $\mu \mathrm{m}$ ).

No aço Hadfield refinado (figura 52-a), os grãos equiaxiais possuem orientação cristalográfica aleatória, em torno de [221], [110], [321], [331] e [100], como está indicado na figura de polo inversa para o sistema cúbico (figura 52-b). Os grãos austeníticos tem um tamanho de aproximadamente 600 $\mu \mathrm{m}$, não sendo observada a presença de subgrãos. 
Figura 50 - Aço Hadfield sem refino. (a) Resultado da técnica EBSD na região colunar do aço Hadfield. Ataque químico: Nital 3\%; (b) Indicação dos grãos marcados em (a) na figura de polo inversa para o sistema cúbico.

(a)

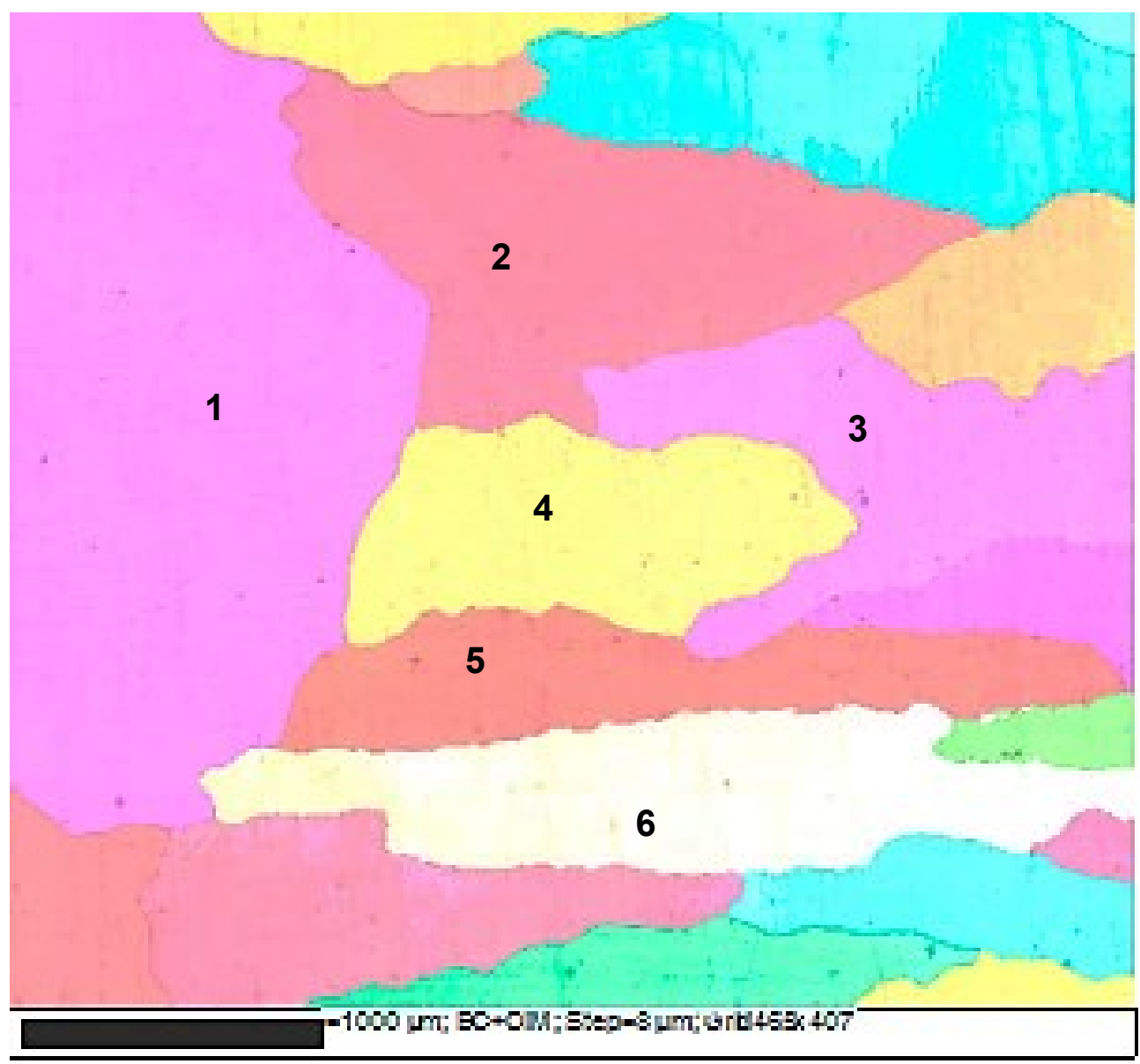

(b)

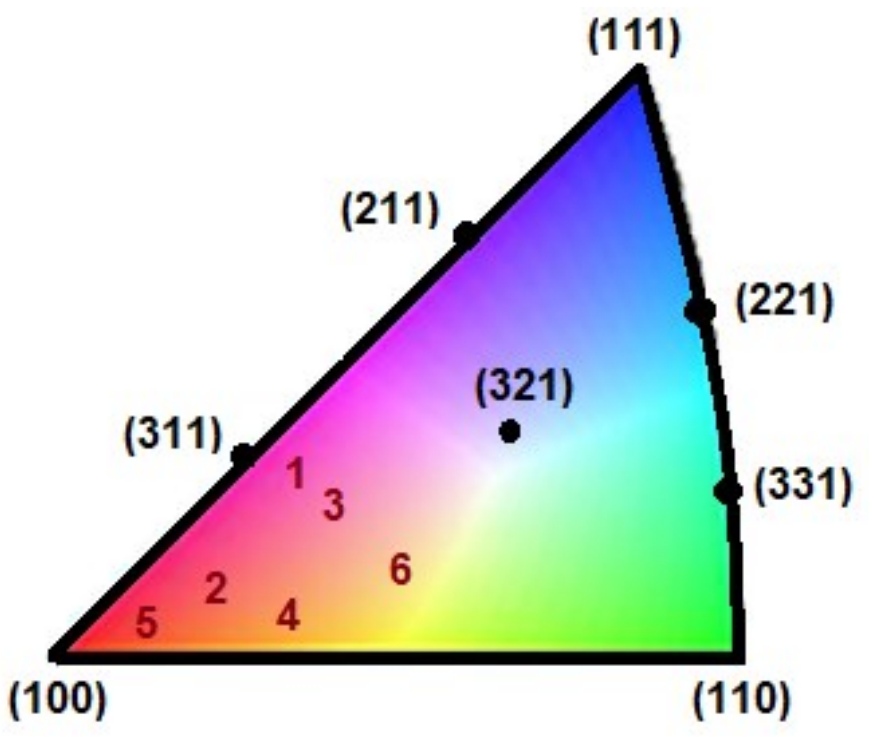


Figura 51 - Aço Hadfield sem refino. (a) Resultado da técnica EBSD na região central (grãos equiaxiais) do aço Hadfield sem refino. Ataque químico: Nital 3\%; (b) Indicação dos grãos marcados em (a) na figura de polo inversa para o sistema cúbico.

(a)

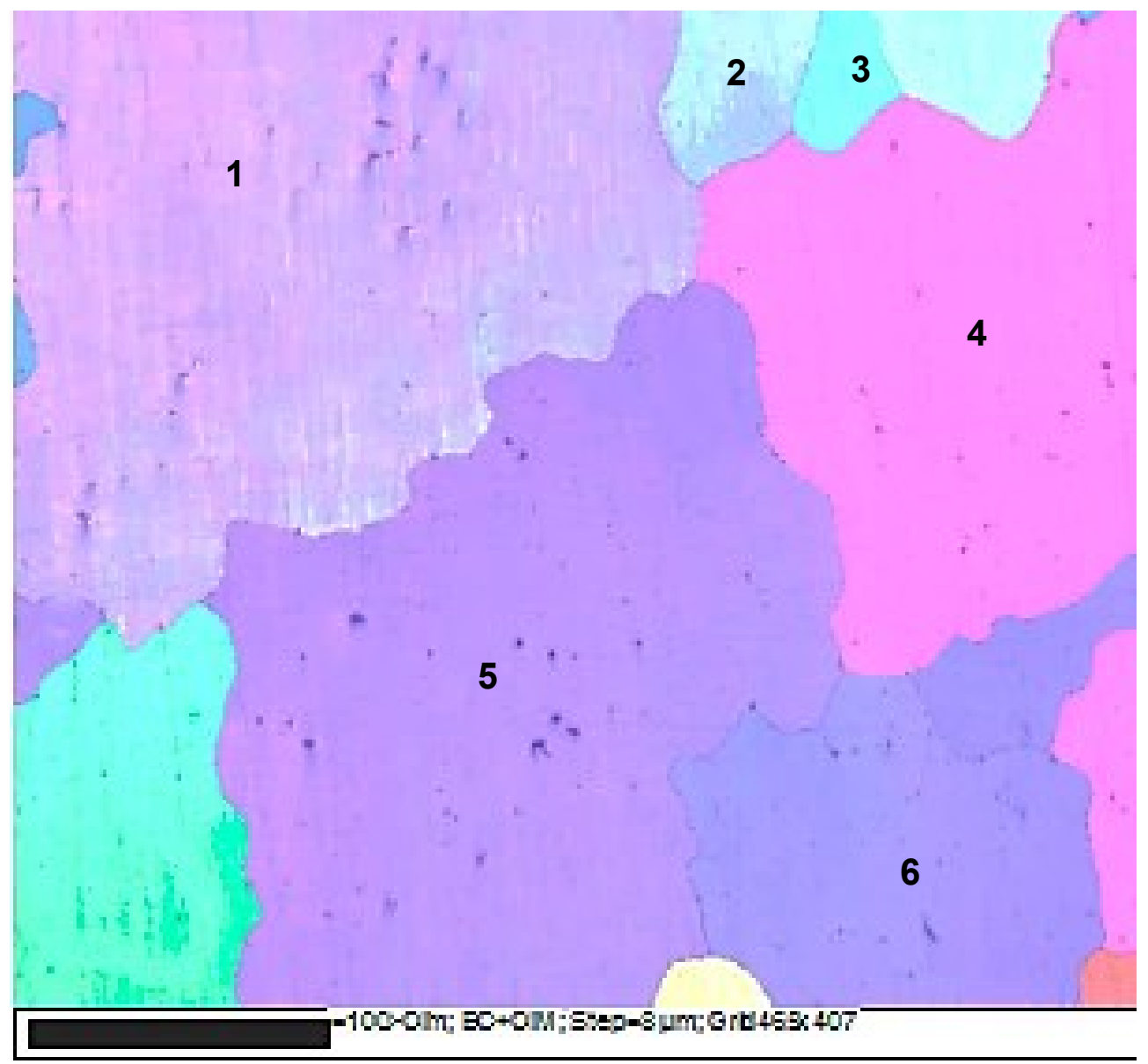

(b)

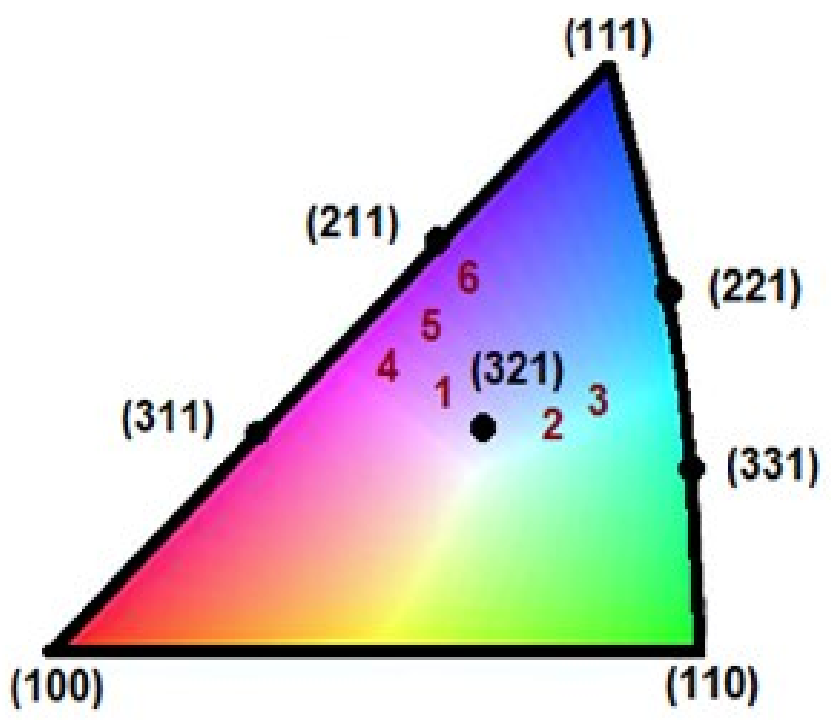


Figura 52 - Aço Hadfield refinado com 0,1\% Hf. (a) Resultado da técnica EBSD na região central do aço Hadfield refinado com Hf. Ataque químico: Nital 3\%; (b) Indicação dos grãos marcados em (a) na figura de polo inversa para o sistema cúbico.

(a)

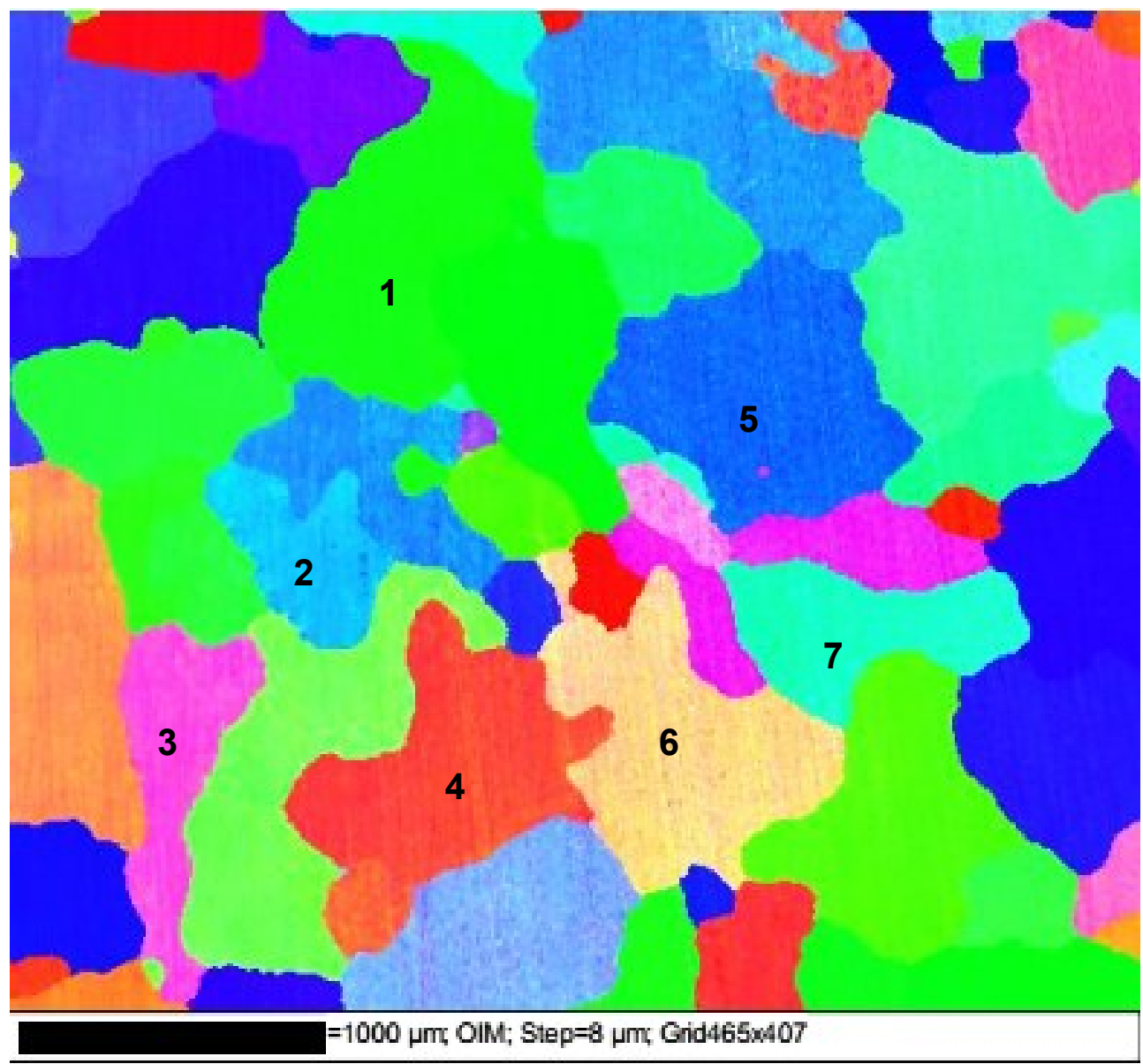

(b)

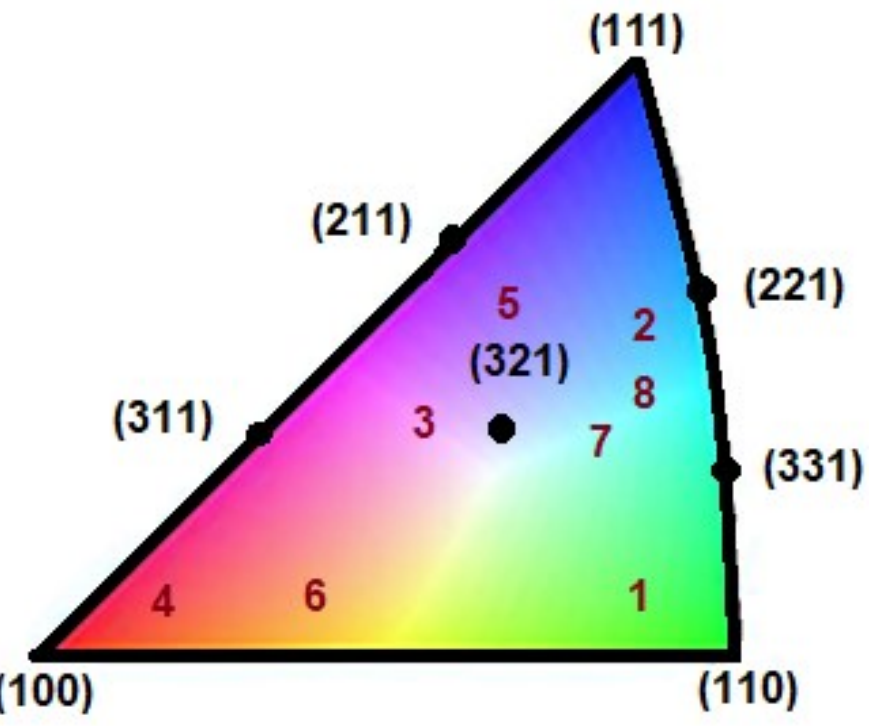




\subsubsection{Determinação do tamanho de grão austeníticos}

A determinação do tamanho de grão austenítico do aço Hadfield da condição sem refino é dificultada pela presença de três zonas distintas (coquilhada, colunar e equiaxial) e pelo "grande" tamanho dos grãos, que não é compatível com a escala de uma micrografia (vide na figura 47), por isso a macrografia fornece medidas com maior precisão (vide nas figuras 45-a e 46a). Para a condição refinada com $0,1 \% \mathrm{Hf}$, os contornos de grão são mais nítidos nas imagens de EBSD (figura 52-a) do que nas macrografias (figuras 45-b e 46-b).

As medidas do tamanho dos grãos obtidas por diferentes métodos descritos no capítulo de Materiais e Métodos são mostradas na tabela 8. Observa-se que o aço Hadfield refinado possui tamanho de grão equiaxial médio $(600 \mu \mathrm{m})$ aproximadamente cinco vezes menor do que a zona equiaxial do aço Hadfield sem refino $(3000 \mu \mathrm{m})$. O tamanho do grão da zona colunar do aço Hadfield sem refino $(5000 \mu \mathrm{m})$ é $67 \%$ maior do que o grão equiaxial do aço Hadfield sem refino $(3000 \mu \mathrm{m})$.

Tabela 8 - Tamanho de grão austenítico do aço Hadfield sem refino e refinado com $0,1 \% \mathrm{Hf}$.

\begin{tabular}{|c|c|c|c|c|}
\hline Amostra & $\begin{array}{c}\text { Tamanho do } \\
\text { grão- macrografia } \\
(\mu \mathrm{m})\end{array}$ & $\begin{array}{c}\text { Tamanho de grão } \\
\text { da norma ASTM } \\
\text { E112-96 }(\mu \mathrm{m})\end{array}$ & $\begin{array}{c}\text { Tamanho } \\
\text { de grão- } \\
\text { EBSD }(\mu \mathrm{m})\end{array}$ & $\begin{array}{c}\text { Tamanho de } \\
\text { grão médio } \\
(\mu \mathrm{m})\end{array}$ \\
\hline $\begin{array}{c}\text { Aço Hadfield sem } \\
\text { refino, zona } \\
\text { colunar }\end{array}$ & $6000 \pm 2000$ & $4000 \pm 2000$ & 5000 \\
\hline $\begin{array}{c}\text { Aço Hadfield sem } \\
\text { refino, zona } \\
\text { equiaxial }\end{array}$ & $3000 \pm 1000$ & $2000 \pm 1000$ & - & 3000 \\
\hline $\begin{array}{c}\text { Aço Hadfield } \\
\text { refinado com 0,1\% } \\
\text { Hf }\end{array}$ & $700 \pm 300$ & $600 \pm 300$ & $600 \pm 300$ & 600 \\
\hline $\begin{array}{c}\text { Relação de refino } \\
\text { em relação á zona } \\
\text { equiaxial do aço } \\
\text { Hadfield sem refino }\end{array}$ & 4,3 & 3,5 & & 5 \\
\hline
\end{tabular}




\subsection{RESULTADOS DO ENSAIO DE TRAÇÃO DAS AMOSTRAS SOLUBILIZADAS}

Os gráficos da tensão em função da deformação verdadeira para os três corpos de prova do aço Hadfield sem refino e refinado após solubilização a $1120^{\circ} \mathrm{C}$ por 10 horas são apresentados nas figuras 53 e 54 . Observa-se que os corpos de prova (cp 1, cp 2 e cp 3) possuem curvas tensão - deformação bastante semelhantes tanto na condição refinada quanto na condição sem refino.

A figura 55 compara os melhores resultados da curva tensão deformação das condições sem refino e refinado. A análise qualitativa da figura 56 sugere que o aço Hadfield refinado apresenta maiores valores das propriedades mecânicas de resistência à tração, ductilidade e tenacidade à fratura do que o aço Hadfield sem refino. Aparentemente não existem diferenças significativas entre a condição refinada e não refinada com relação ao limite de escoamento.

Figura 53 - Gráfico da tensão x deformação verdadeira do aço Hadfield sem refino para os 3 corpos de prova ensaiados por tração.

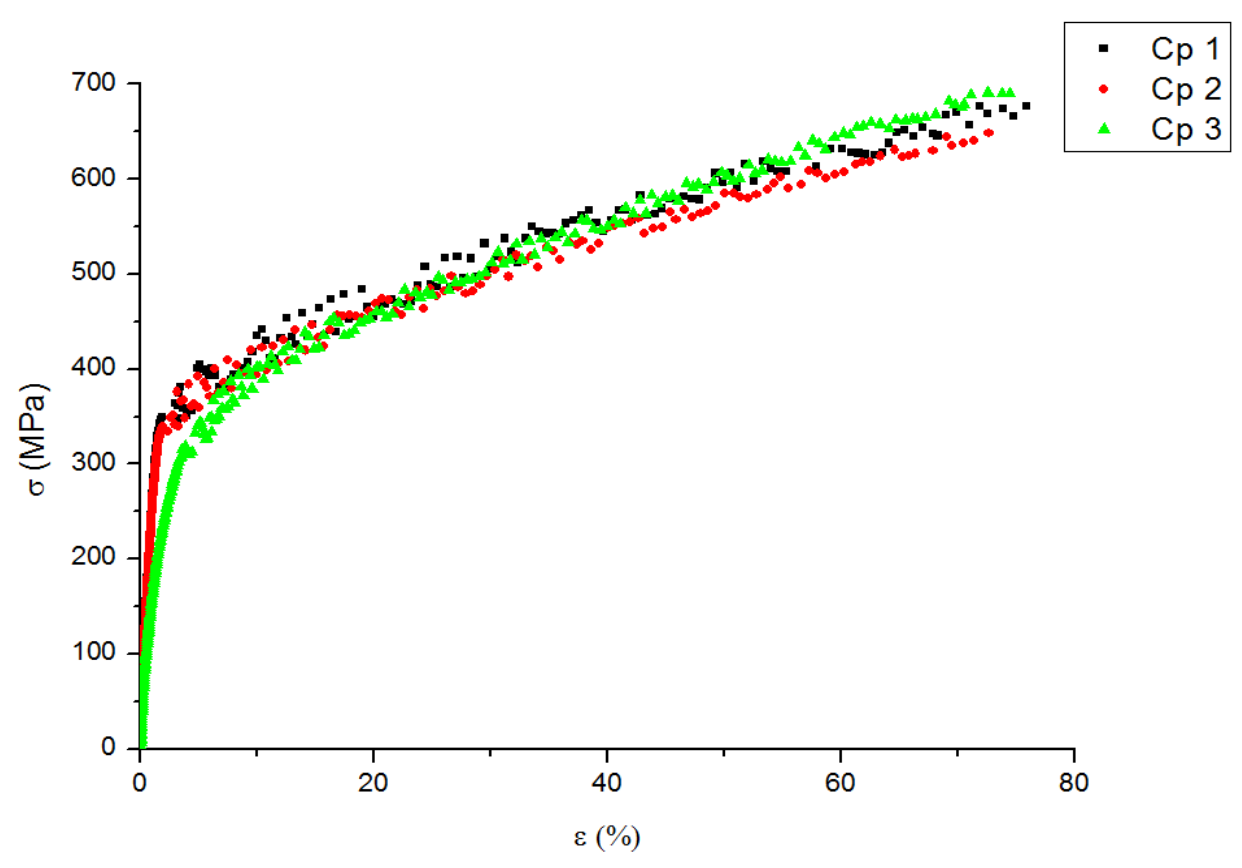


Figura 54 - Gráfico da tensão x deformação verdadeira do aço Hadfield refinado com 0,1\% Hf para os 3 corpos de prova ensaiados por tração.

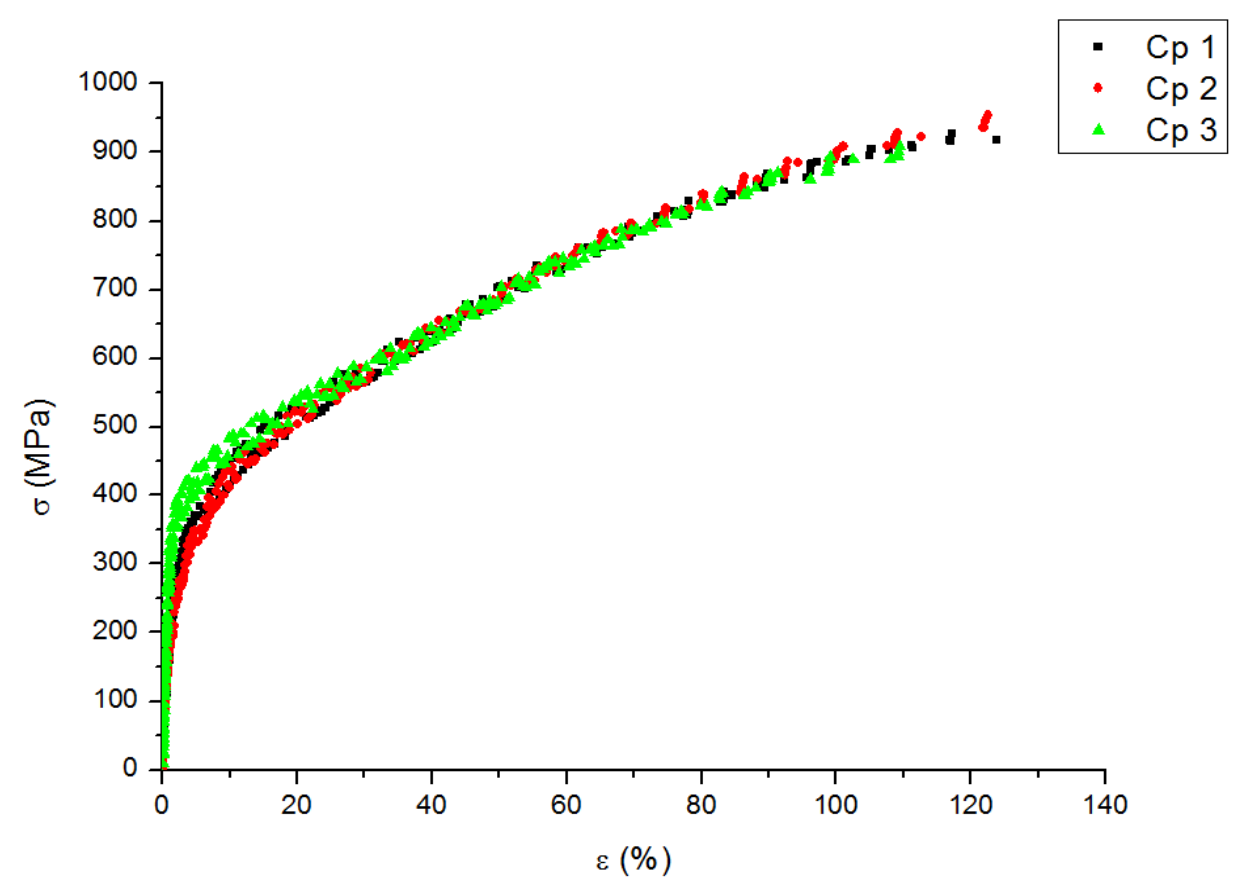

Figura 55 - Gráfico da tensão x deformação verdadeira do aço Hadfield sem refino e refinado com $0,1 \% \mathrm{Hf}$ ensaiados por tração.

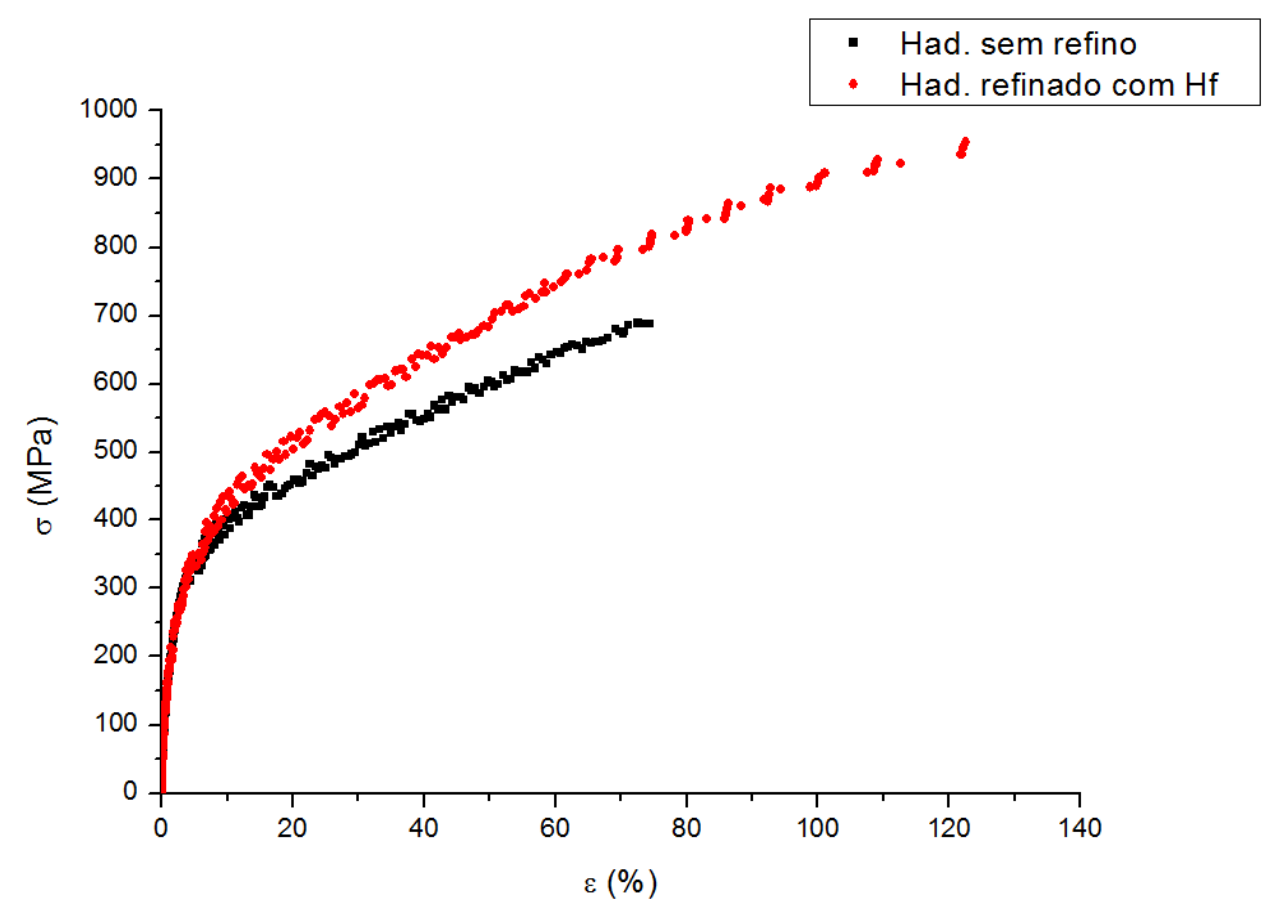


As tabelas 9 e 10 mostram as propriedades de tração obtidas no ensaio de tração do aço Hadfield sem refino e refinado e os respectivos intervalos de confiança. Os três corpos de prova de aço Hadfield sem refino e refinado apresentaram valores semelhantes das propriedades mecânicas de tração, com baixo desvio padrão (varia de 9 a 26), com exceção da resiliência que variou de 240 a 330 MPa para o aço Hadfield sem refino (desvio padrão de 45), e variou de 260 a 340 MPa para o aço Hadfield refinado (desvio padrão de 42).

Tabela 9 - Propriedades mecânicas de tração do aço Hadfield sem refino.

\begin{tabular}{|c|c|c|c|c|}
\hline $\begin{array}{c}\text { Propriedades mecânicas de } \\
\text { tração }\end{array}$ & CP 1 & CP 2 & CP 3 & Média \\
\hline Limite de escoamento (MPa) & $340 \pm 11$ & $340 \pm 11$ & $320 \pm 11$ & 334 \\
\hline Resiliência (MPa) & $330 \pm 45$ & $280 \pm 45$ & $240 \pm 45$ & 282 \\
\hline Módulo de Young (MPa) & $170 \pm 26$ & $205 \pm 26$ & $220 \pm 26$ & 199 \\
\hline Tenacidade (MPa) & $420 \pm 9$ & $400 \pm 9$ & $410 \pm 9$ & 409 \\
\hline Alongamento (\%) & $50 \pm 5$ & $45 \pm 5$ & $40 \pm 5$ & 46,5 \\
\hline Resistência à tração (MPa) & $690 \pm 26$ & $650 \pm 26$ & $700 \pm 26$ & 681 \\
\hline Coeficiente de encruamento & 0,6 & 0,55 & 0,62 & 0,6 \\
\hline
\end{tabular}

Tabela 10 - Propriedades mecânicas de tração do aço Hadfield refinado com 0,1\%Hf.

\begin{tabular}{|c|c|c|c|c|}
\hline $\begin{array}{c}\text { Propriedades mecânicas de } \\
\text { tração }\end{array}$ & CP 1 & CP 2 & CP 3 & Média \\
\hline Limite de escoamento (MPa) & $360 \pm 11$ & $340 \pm 11$ & $360 \pm 11$ & 355 \\
\hline Resiliência (MPa) & $320 \pm 42$ & $260 \pm 42$ & $340 \pm 42$ & 304 \\
\hline Módulo de Young (MPa) & $205 \pm 20$ & $230 \pm 20$ & $190 \pm 20$ & 208 \\
\hline Tenacidade (MPa) & $770 \pm 10$ & $780 \pm 10$ & $760 \pm 10$ & 771 \\
\hline Alongamento (\%) & $75 \pm 5$ & $68 \pm 5$ & --- & 71 \\
\hline Resistência à tração (MPa) & $930 \pm 20$ & $950 \pm 20$ & $910 \pm 20$ & 931 \\
\hline Coeficiente de encruamento & 0,85 & 0,9 & 0,8 & 0,85 \\
\hline
\end{tabular}


A tabela 11 mostra a comparação dos valores médios das propriedades de tração entre o aço Hadfield sem refino e refinado. A tenacidade $\left(u_{t}\right)$ foi calculada através da equação 3 para materiais dúcteis (DIETER, 1981).

$$
u_{t}=\frac{\sigma_{R T+} \sigma_{e}}{2} \cdot \varepsilon_{f}
$$

Sendo: $\sigma_{\mathrm{RT}}=$ resistência à tração $(\mathrm{MPa}), \sigma_{\mathrm{e}}=$ limite de escoamento $(\mathrm{MPa})$ e $\varepsilon_{\mathrm{f}}$ = deformação final.

Tabela 11 - Comparação entre as propriedades mecânicas de tração do aço Hadfield sem refino e do aço Hadfield refinado com $0,1 \% \mathrm{Hf}$ tomando-se os valores médios.

\begin{tabular}{|c|c|c|c|}
\hline $\begin{array}{c}\text { Propriedades mecânicas de } \\
\text { tração (valores médios) }\end{array}$ & $\begin{array}{c}\text { Aço Hadfield } \\
\text { sem refino }\end{array}$ & $\begin{array}{c}\text { Aço Hadfield } \\
\text { refinado }\end{array}$ & $\begin{array}{c}\text { Variação } \\
\text { (\%) }\end{array}$ \\
\hline Limite de escoamento (MPa) & 334 & 355 & $\uparrow 6$ \\
\hline Resiliência (MPa) & 282 & 304 & $\uparrow 8$ \\
\hline Módulo de Young (MPa) & 199 & 208 & $\uparrow 5$ \\
\hline Tenacidade (MPa) & 409 & 771 & $\uparrow 88$ \\
\hline Alongamento (\%) & 46,5 & 71 & $\uparrow 53$ \\
\hline Resistência à tração (MPa) & 681 & 931 & $\uparrow 37$ \\
\hline Coeficiente de encruamento & 0,6 & 0,85 & $\uparrow 30$ \\
\hline
\end{tabular}

Observa-se na tabela 11 que não foram obtidos aumentos significativas nos valores médios do limite de escoamento, da resiliência e do módulo de Young com a diminuição do tamanho de grão. No entanto, a resistência à tração do aço Hadfield refinado aumentou em $37 \%$ e seu alongamento aumentou em 53\% em comparação com o aço Hadfield sem refino (valores médios). Adicionalmente, os valores extrapolados da tenacidade, calculados a partir das curvas de tensão versus deformação (vide equação 3), mostraram que o refino aumentou a tenacidade em aproximadamente $88 \%$. 


\subsubsection{Fractografias dos corpos de prova rompidos no ensaio de tração}

As superfícies de fratura dos corpos de prova de aço Hadfield sem refino e refinado solubilizados e rompidos no ensaio de tração estão registradas nas figuras 56 a 59. As figuras 56-a e 56-b mostram uma visão geral dos corpos de prova rompidos no ensaio de tração. As figuras 57-a e 57-b mostram a superfície lateral dos corpos de prova de aço Hadfield sem refino (figura 57-a) e refinado (figura 57-b) rompidos no ensaio de tração, utilizando microscopia eletrônica de varredura (MEV). A análise qualitativa das macrografias e imagens de MEV (figuras 57 e 58) mostram que o aspecto da superfície do aço Hadfield refinado apresenta maior quantidade de "aberturas" do que a superfície de fratura do aço Hadfield sem refino, indicando que pode ter ocorrido maior deformação plástica neste material. Observa-se no interior dessas "aberturas", nas amostras de aço Hadfield sem refino e refinado, que estão presentes heterogeneidades que podem ser inclusões $e$ microporosidades. 
Figura 56 - Aspecto geral da superfície de fratura do aço Hadfield sem refino (a) e aço Hadfield refinado com $0,1 \% \mathrm{Hf}(\mathrm{b})$ após o ensaio de tração.

(a)

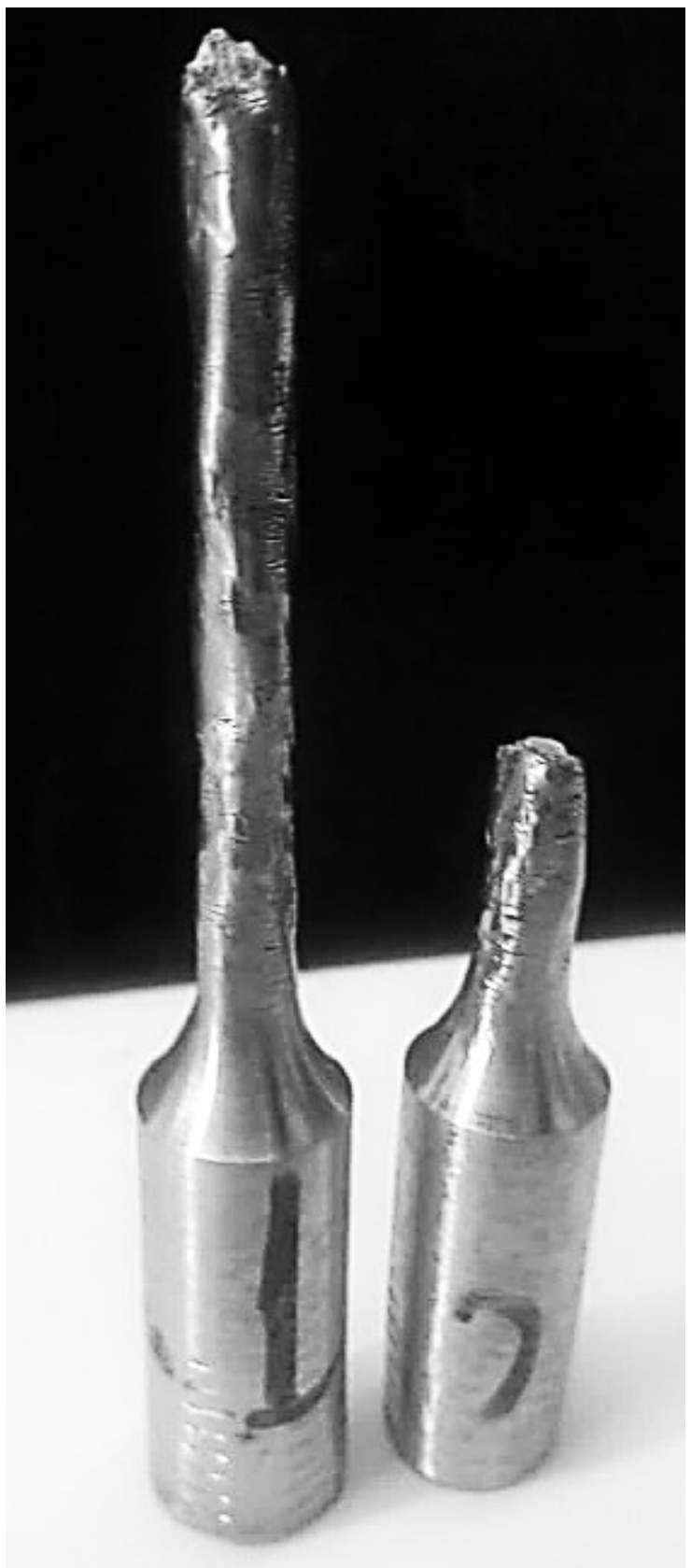

(b)

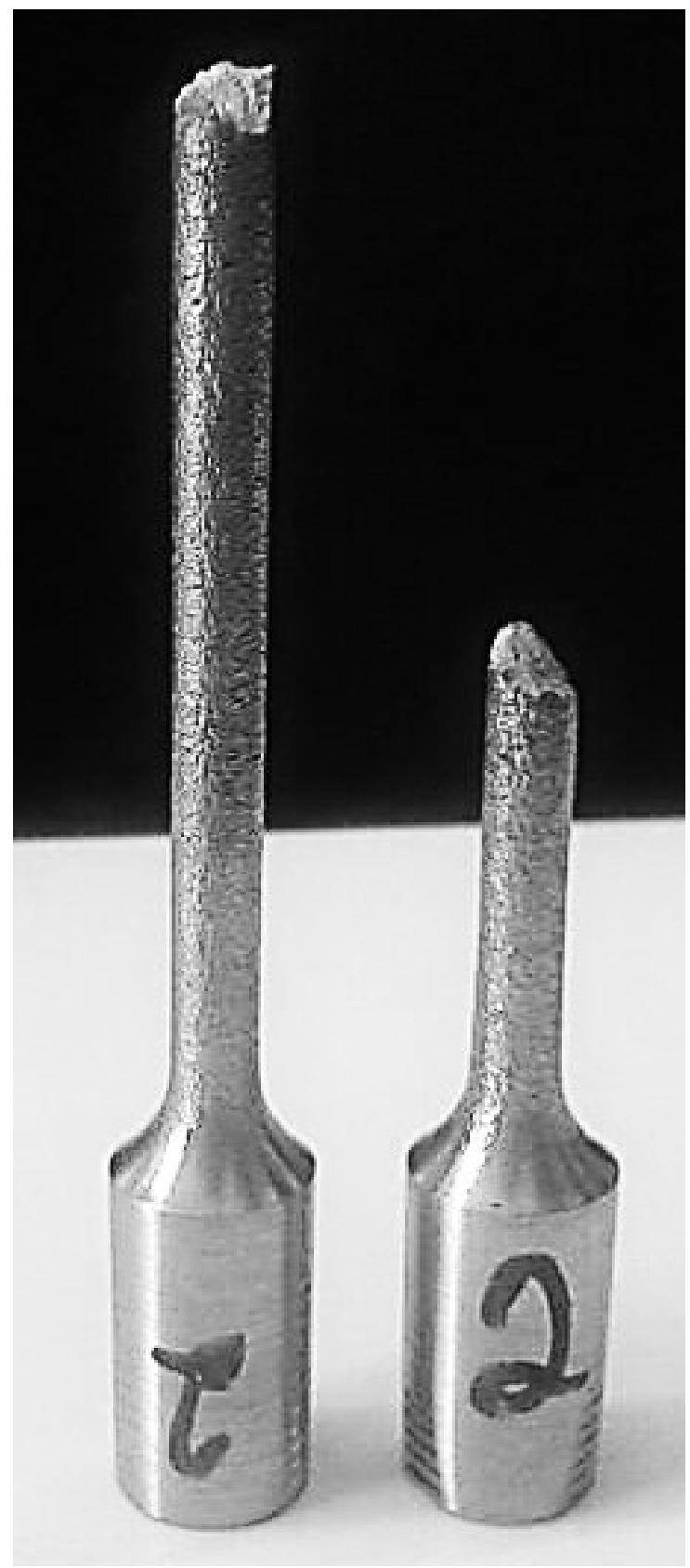


Figura 57 - Aspecto geral da superfície lateral dos corpos de prova de aço Hadfield rompidos no ensaio de tração, (a) aço Hadfield sem refino e (b) aço Hadfield refinado.

(a)

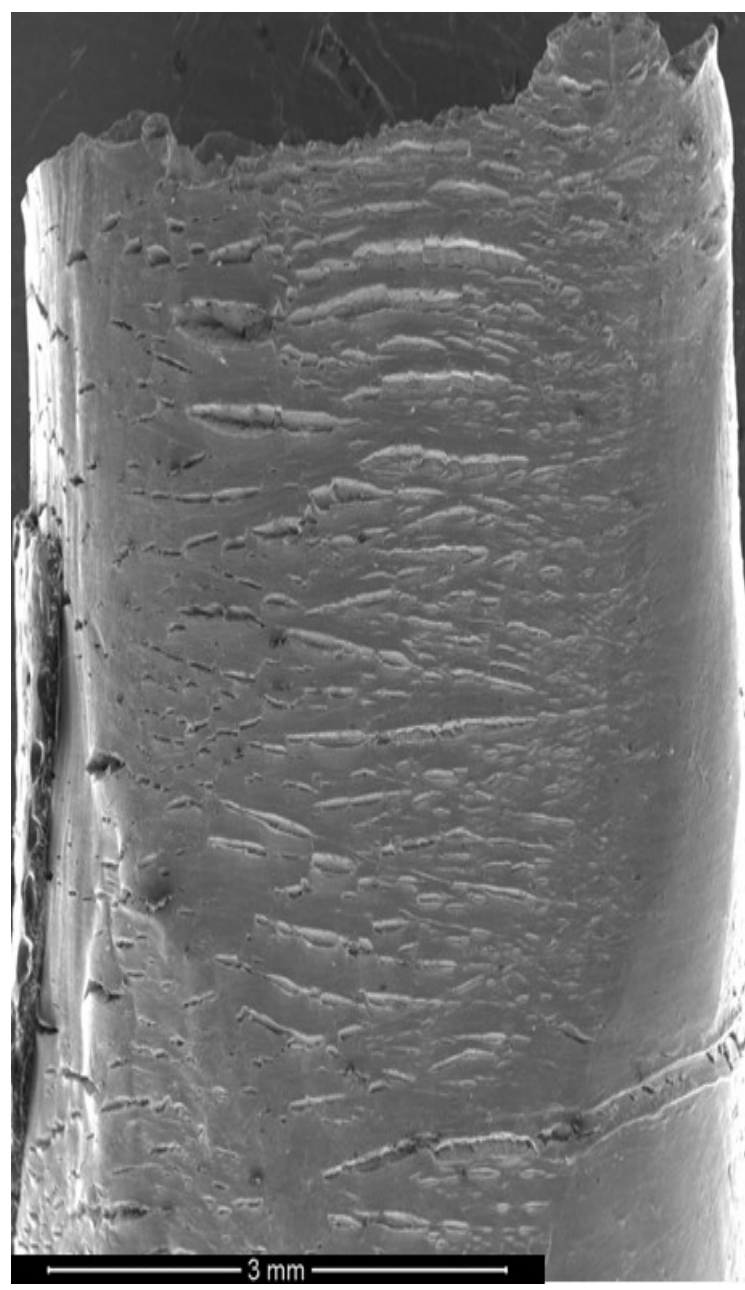

(b)

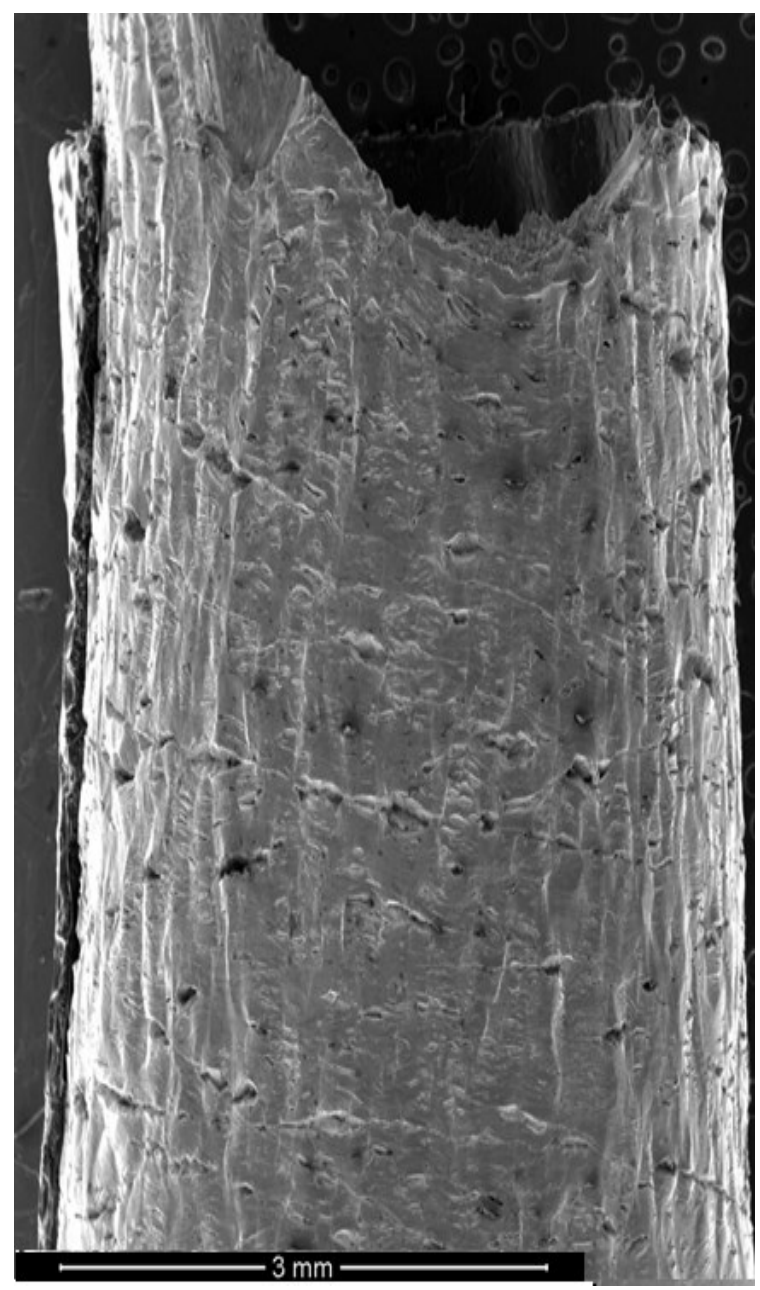

As figuras 58 e 59 mostram as fractografias dos corpos de prova de aço Hadfield sem refino e refinado rompidos no ensaio de tração. A fractografia do aço Hadfield sem refino (figura 58-a) apresenta alvéolos característicos da fratura dúctil com dois diâmetros diferentes (10 $\mu \mathrm{m}$ e $2 \mu \mathrm{m})$, sugerindo a ação de inclusões não-metálicas (diâmetro de 1 - $3 \mu \mathrm{m}$ ) durante a deformação. $\mathrm{Na}$ figura 59-b pode ser observada uma região de fratura por maclação, sendo que as maclas possuem $850 \mathrm{~mm}$ de comprimento. As fractografias do aço Hadfield refinado (figuras 59-a a 59-b) mostram a presença de micro alvéolos (diâmetro de $2 \mu \mathrm{m}$ ), e regiões de deformação por maclação (comprimento de $200 \mu \mathrm{m}$ ). 
Figura 58 - Fractografias do aço Hadfield sem refino após ruptura em ensaio de tração, corpo de prova 2, MEV; (a) Fratura dúctil com a presença de alvéolos, 800x; (b) Maclas de deformação, $2000 \mathrm{x}$.

(a)

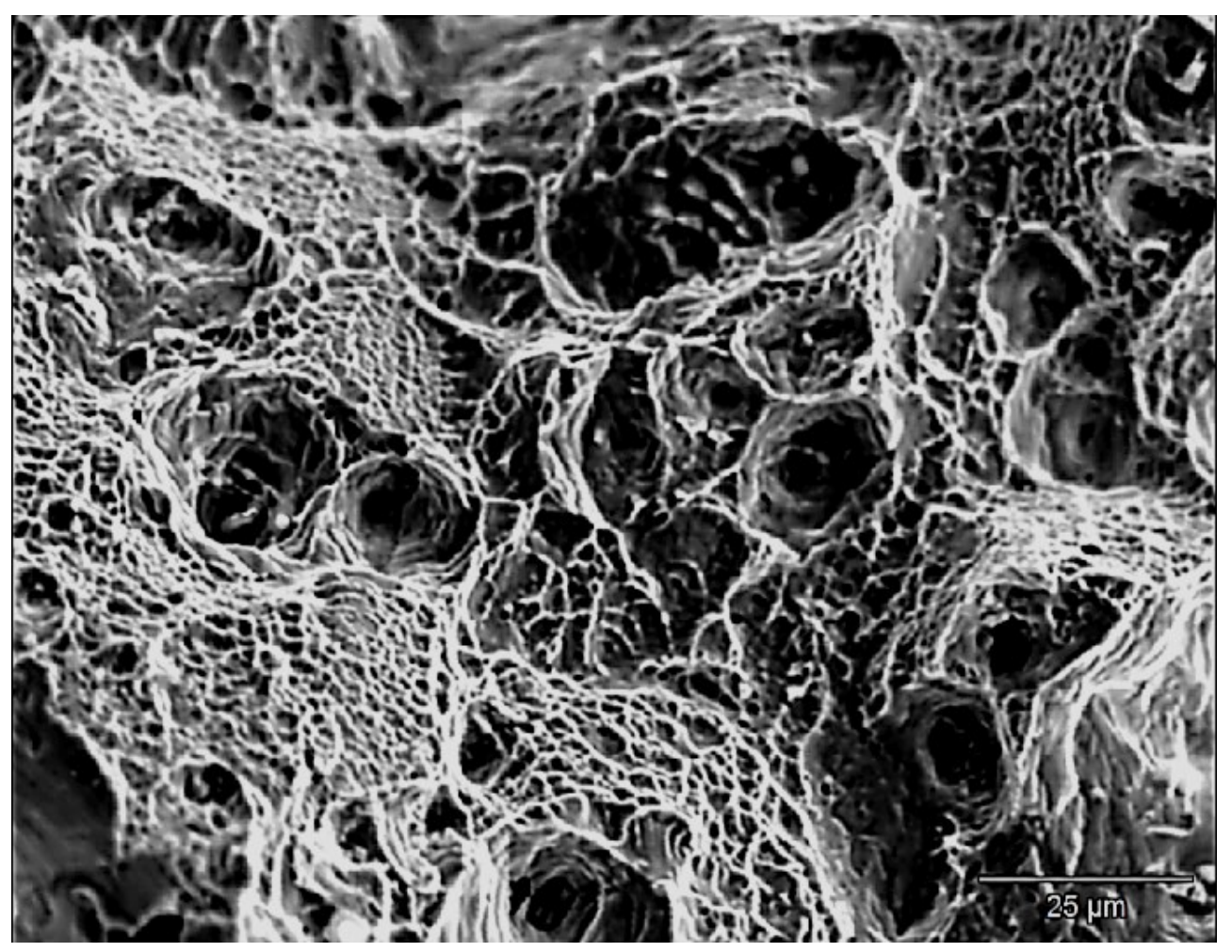

(b)

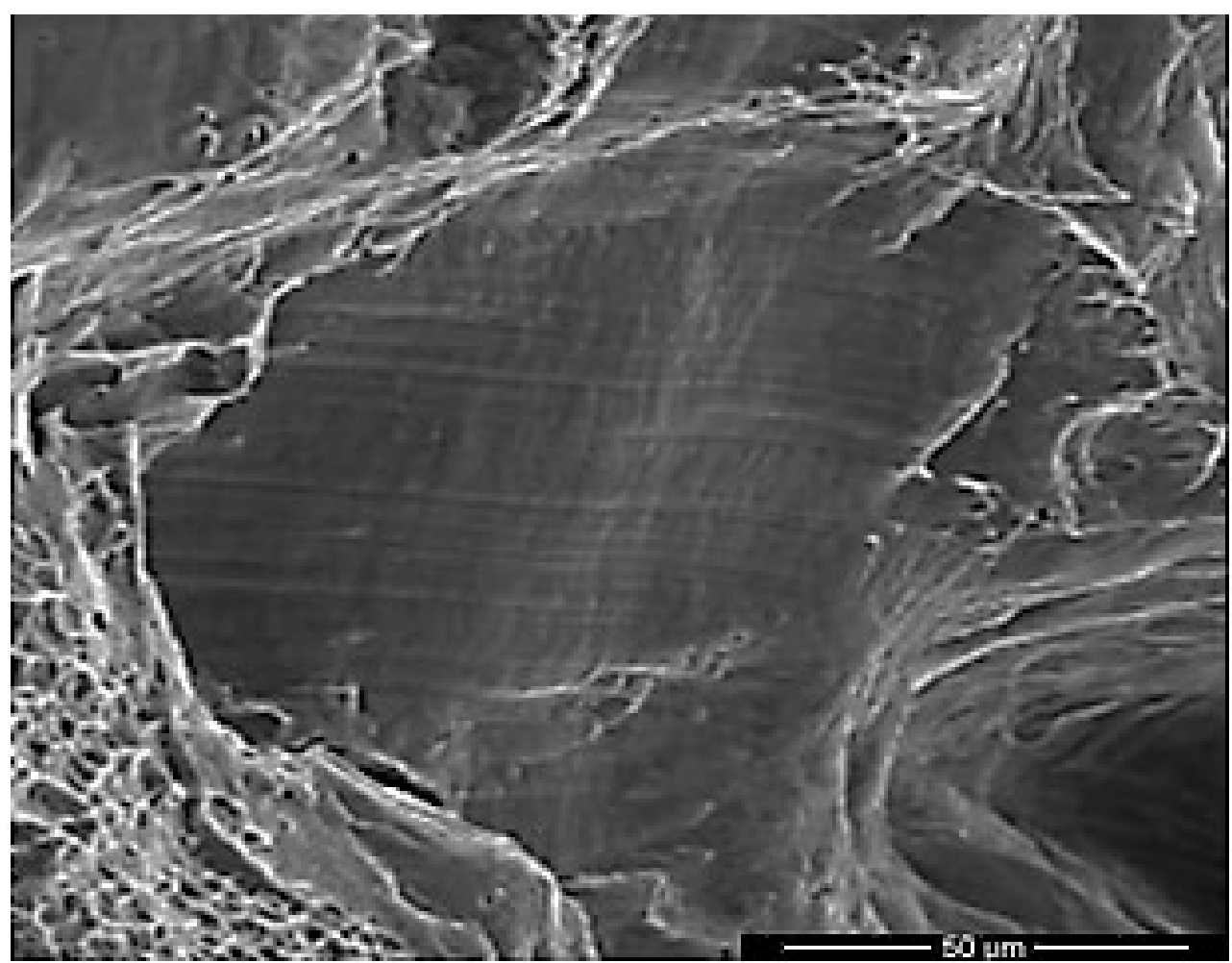


Figura 59 - Fractografias do aço Hadfield refinado após ruptura em ensaio de tração, corpo de prova 2, MEV; (a) Fratura dúctil com a presença de alvéolos, 10000 x; (b) Maclas de deformação, $10000 \mathrm{x}$.

(a)

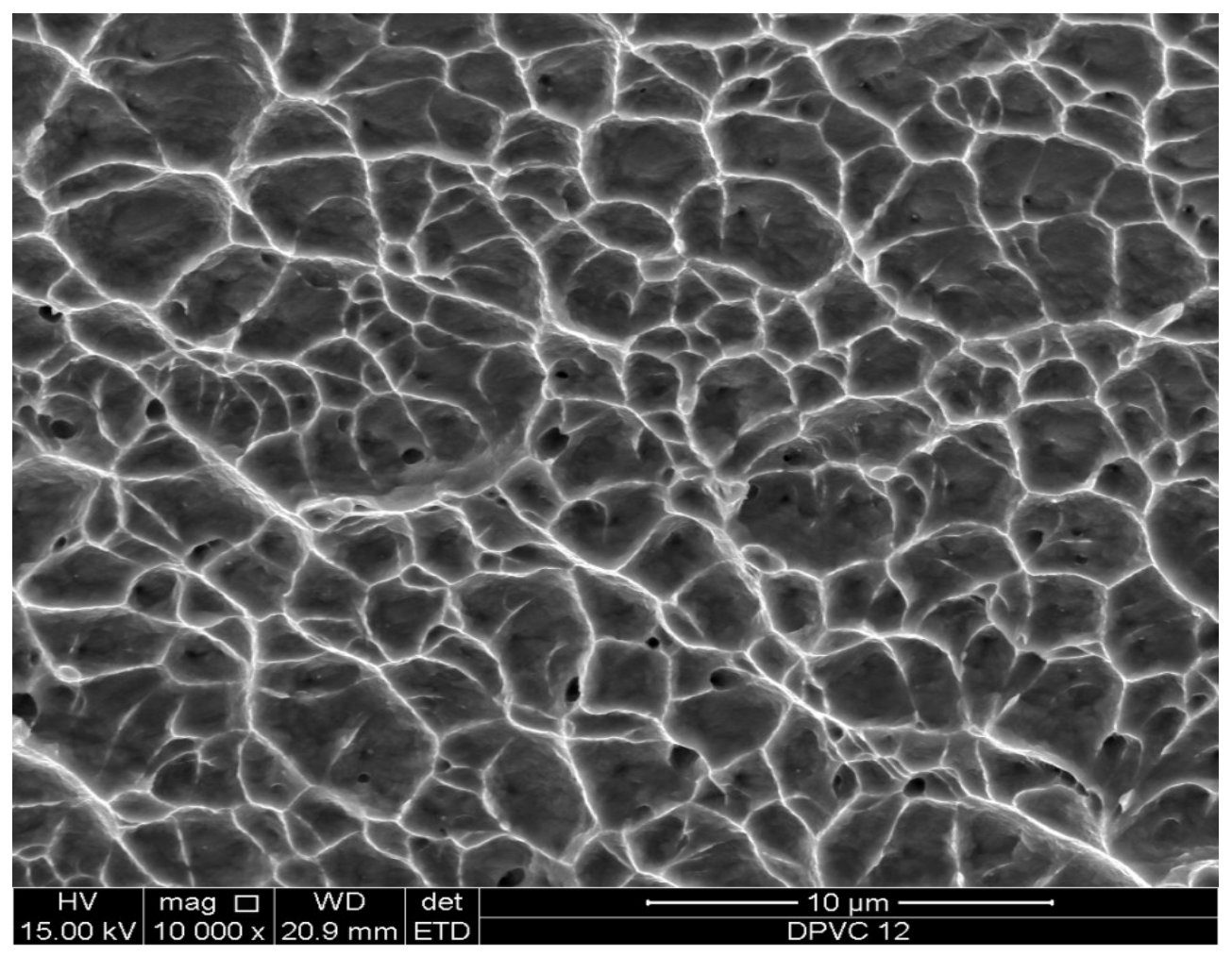

(b)

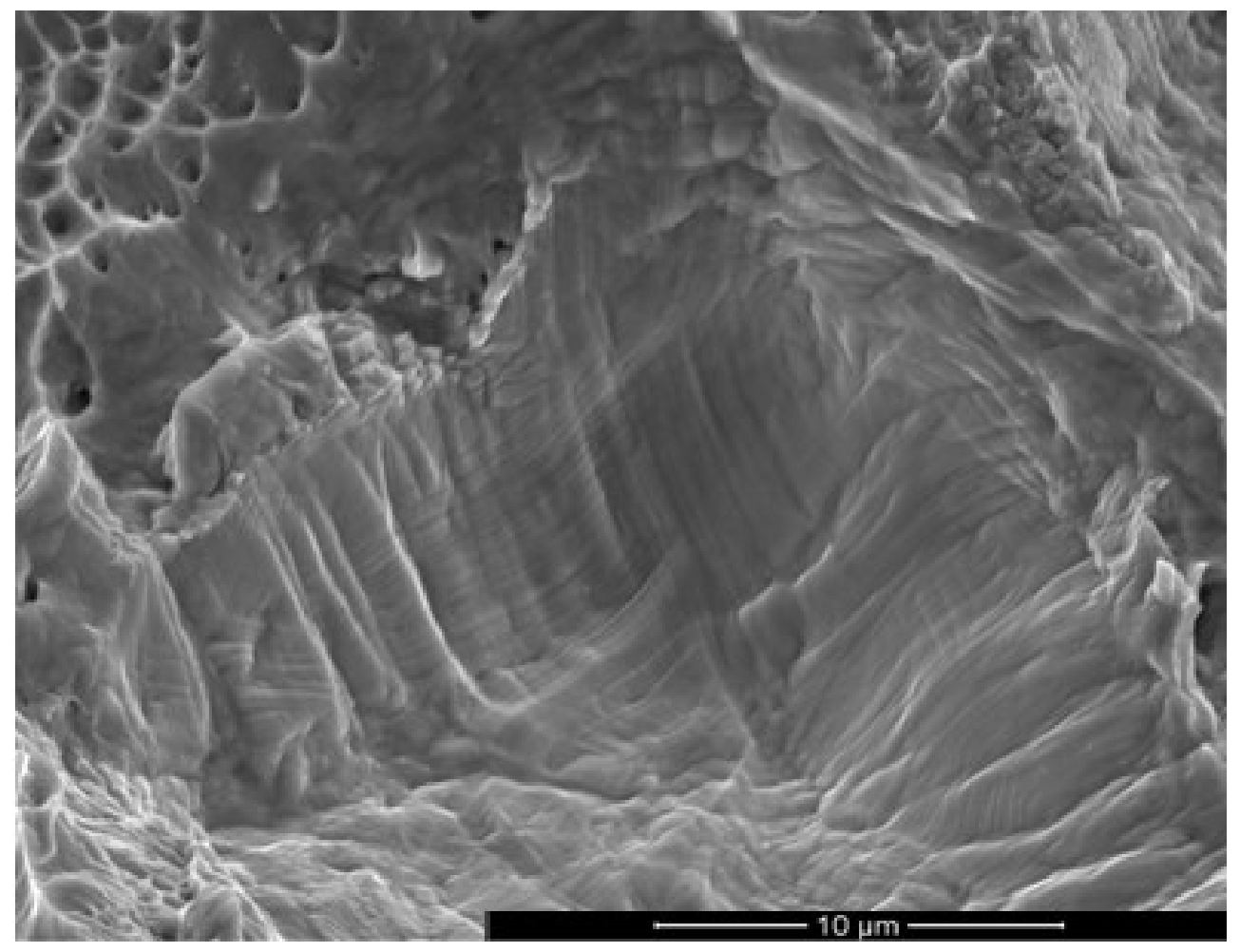


As superfícies de fratura dos aços Hadfield sem refino e refinado após o ensaio de tração foram seccionadas na transversal para caracterização microestrutural (figuras 60-a e 60-b). O aço Hadfield sem refino (figura 60-a) apresenta micro porosidades com comprimento de aproximadamente $50 \mu \mathrm{m}$ e inclusões com diâmetro de aproximadamente $1 \mu \mathrm{m}$, possivelmente relacionados com os dois tamanhos diferentes de alvéolos mostrados anteriormente no exame fractográfico (figura 58-a). Observa-se na figura 60-a uma trinca secundária com comprimento em torno de $720 \mu \mathrm{m}$. A caracterização microestrutural do aço Hadfield refinado mostra a presença de micro porosidades com diferentes comprimentos, na faixa de 10 a $40 \mu \mathrm{m}$, além de inclusões com diâmetro na faixa de 1-2 $\mu \mathrm{m}$.

Figura 60 - Micrografia do corpo de prova de aço Hadfield rompido no ensaio de tração, região próxima à superfície de fratura. (a) aço Hadfield sem refino; (b) aço Hadfield refinado. Aumento original de 100X. Sem ataque químico. Exame em Microscópio óptico.

(a)

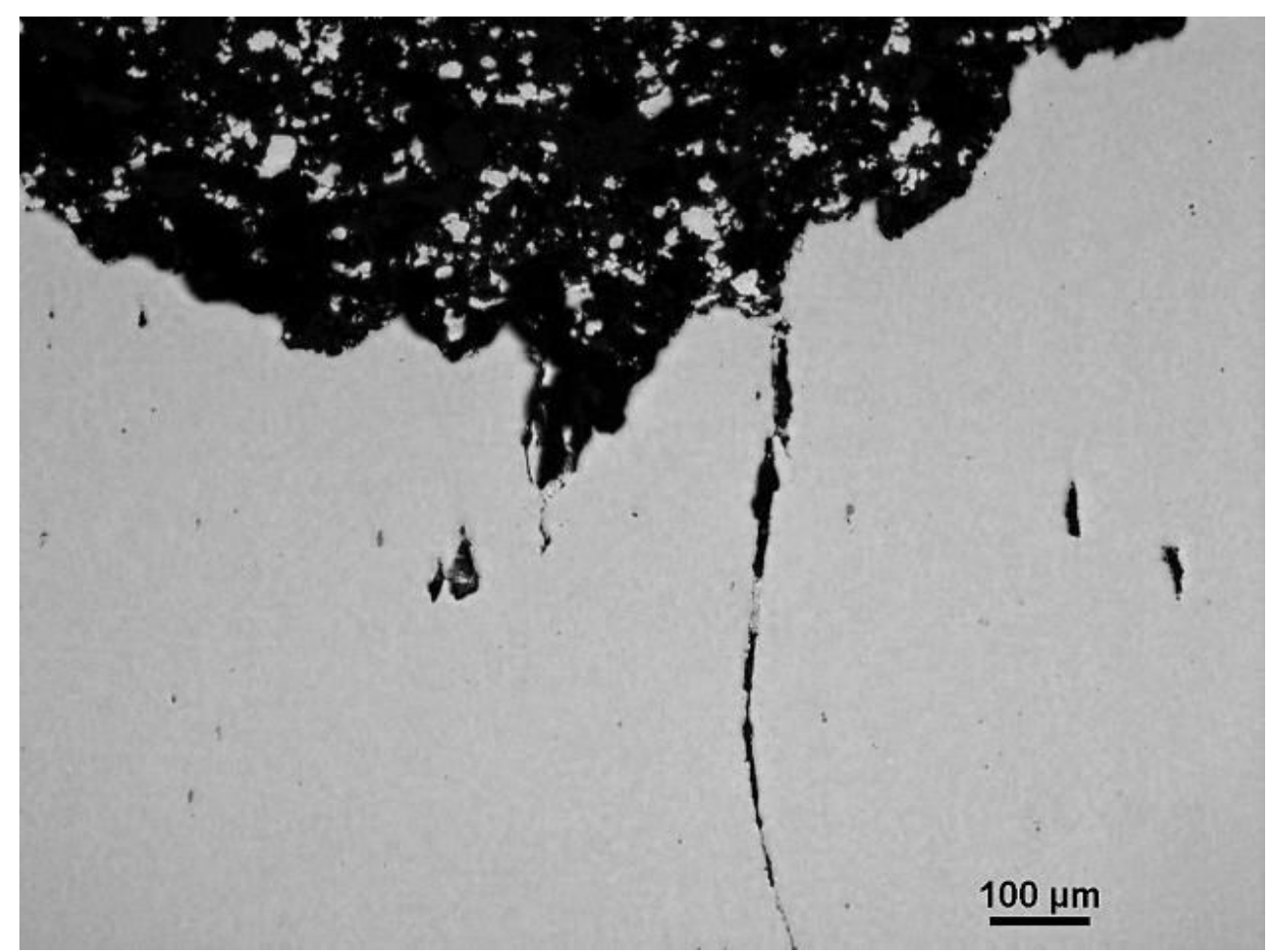


(b)

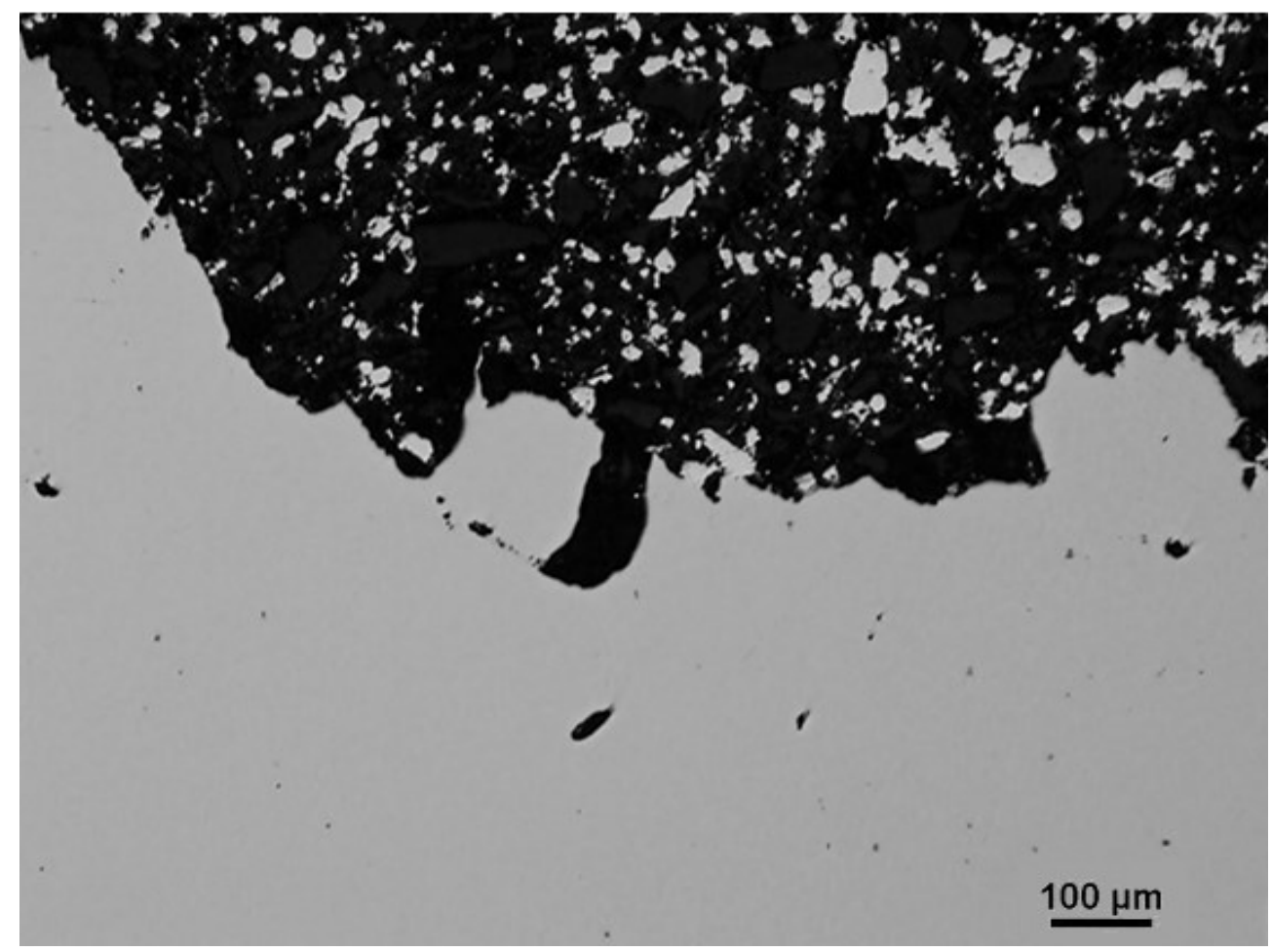

As figuras 61 e 62 mostram a microestrutura na seção transversal próximo da superfície de fratura usando a técnica de EBSD do aço Hadfield para as duas condições. O corpo de prova do aço Hadfield sem refino (figura 61-a) possui maclas de deformação com comprimento em torno de $800 \mu \mathrm{m}$, enquanto que as maclas de deformação presentes no corpo de prova do aço Hadfield refinado (figura 62-b) possuem comprimento de aproximadamente 500 $\mu \mathrm{m}$. A comparação entre as figuras 61-a e 62-a sugere que a deformação por maclação é mais intensa para a condição refinada, visto que a média da densidade de maclas por $\mu \mathrm{m}$ é de 19 para o aço Hadfield sem refino (vide tabela 12) e de 36 para o aço Hadfield refinado (vide tabela 13), correspondendo a um aumento de aproximadamente $46 \%$. Os valores do espaçamento entre as maclas para o aço Hadfield sem refino e refinado estão registrados na tabela 12 e 13, respectivamente. Observa-se que o espaçamento entre as maclas é $33 \%$ maior para a condição sem refino em comparação com a condição refinada. 
Figura 61 - Microestrutura próxima da região da fratura das amostras tracionadas de aço Hadfield sem refino (grãos equiaxiais) mostrando a presença de maclas de deformação, seção transversal, técnica de EBSD.

(a)

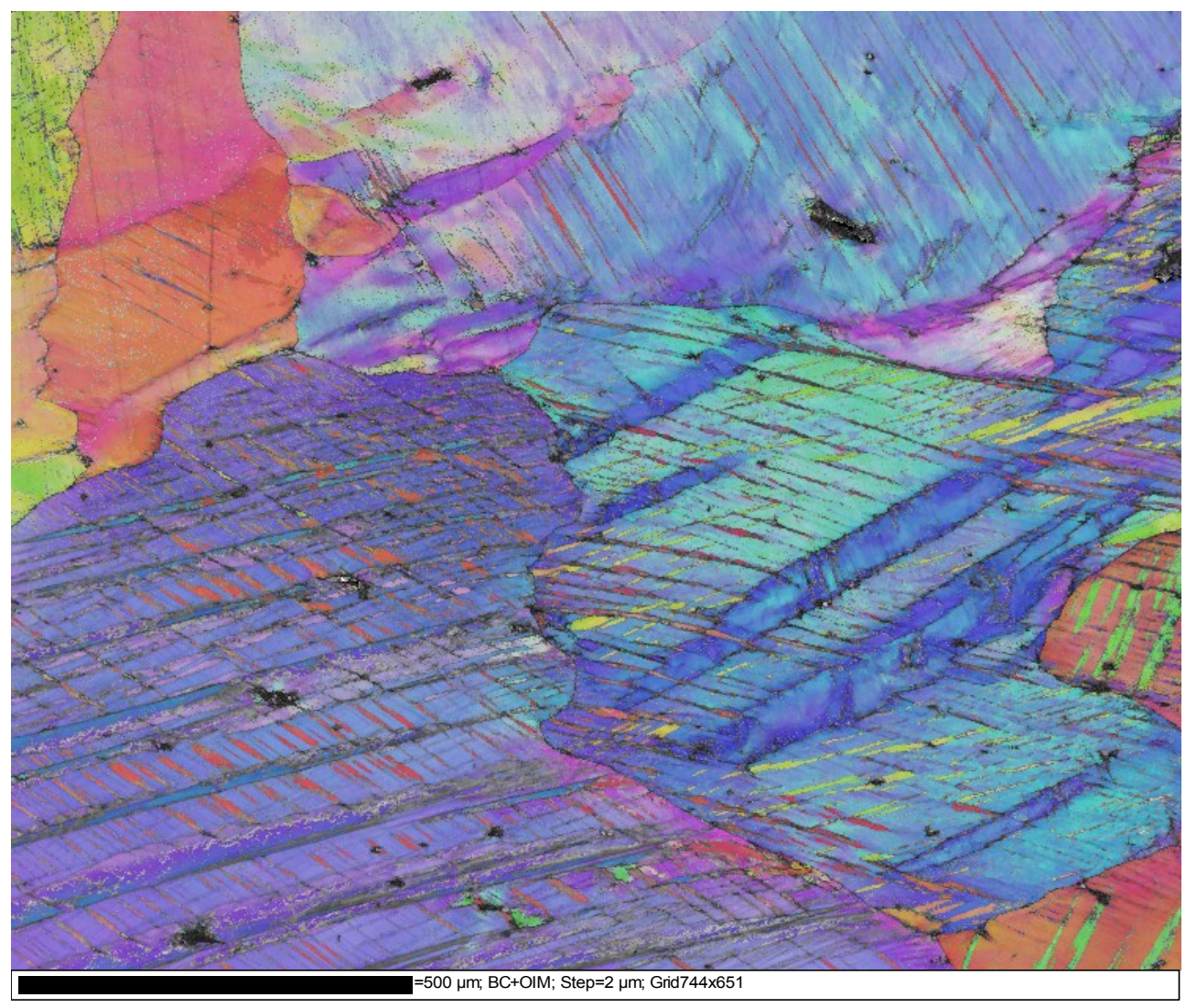

(b)

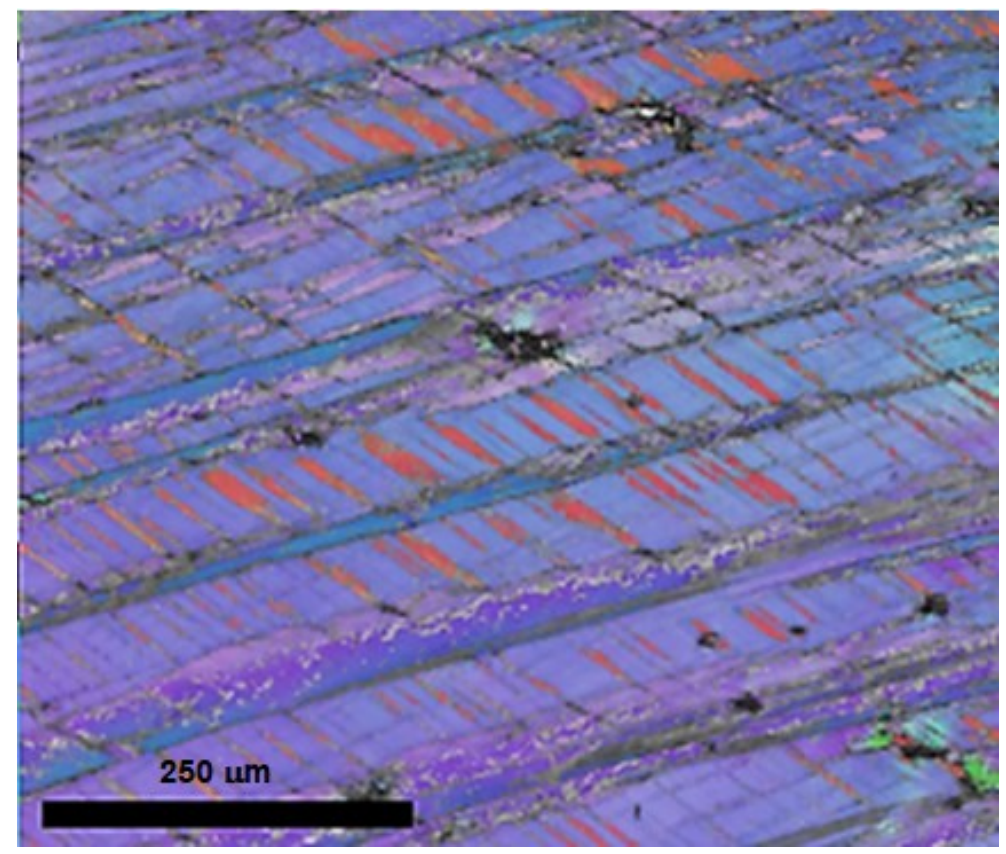


Figura 62 - Microestrutura próxima da região da fratura das amostras tracionadas de aço Hadfield refinado mostrando a presença de maclas de deformação plástica, seção transversal, técnica de EBSD.

(a)

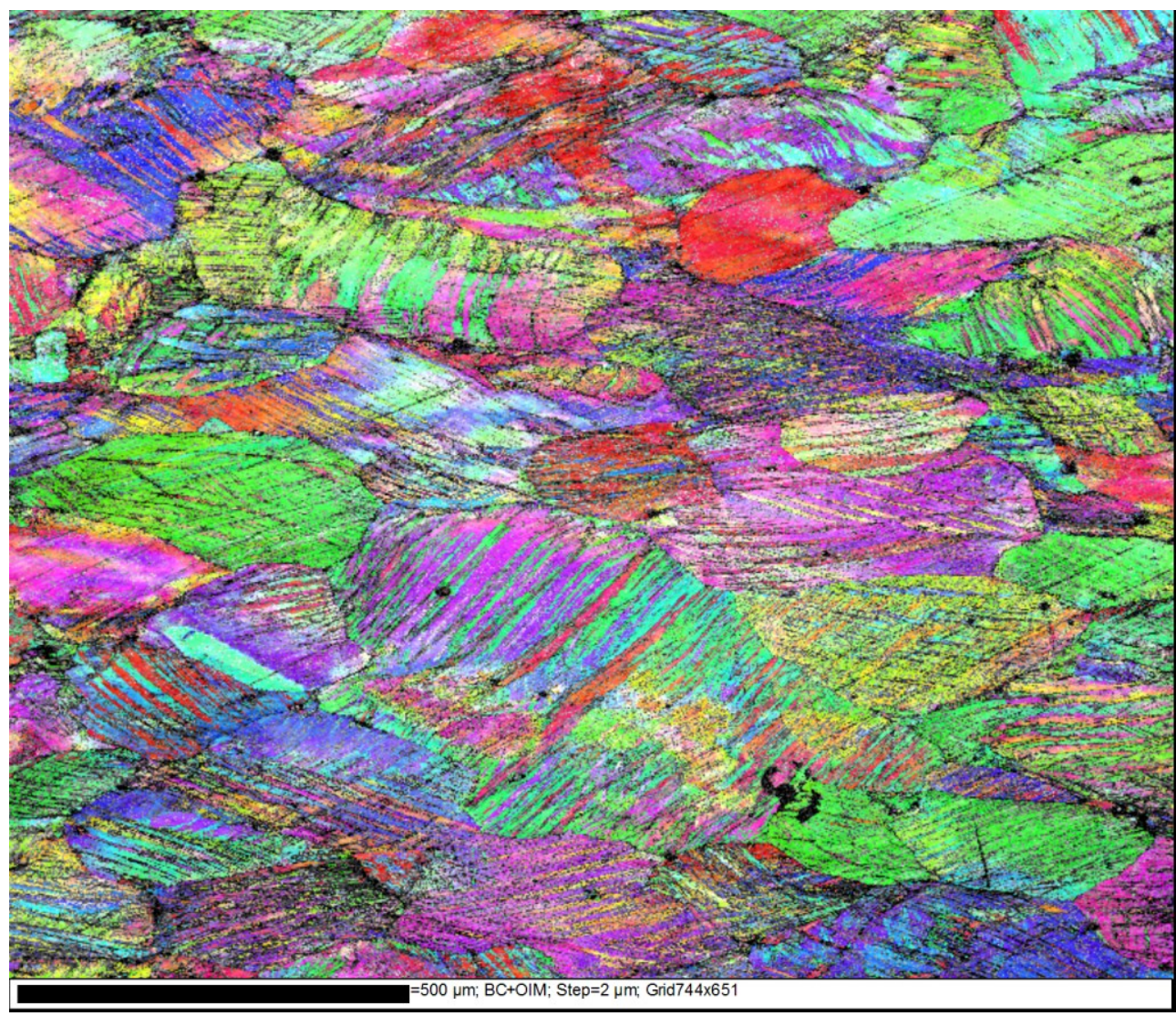

(b)

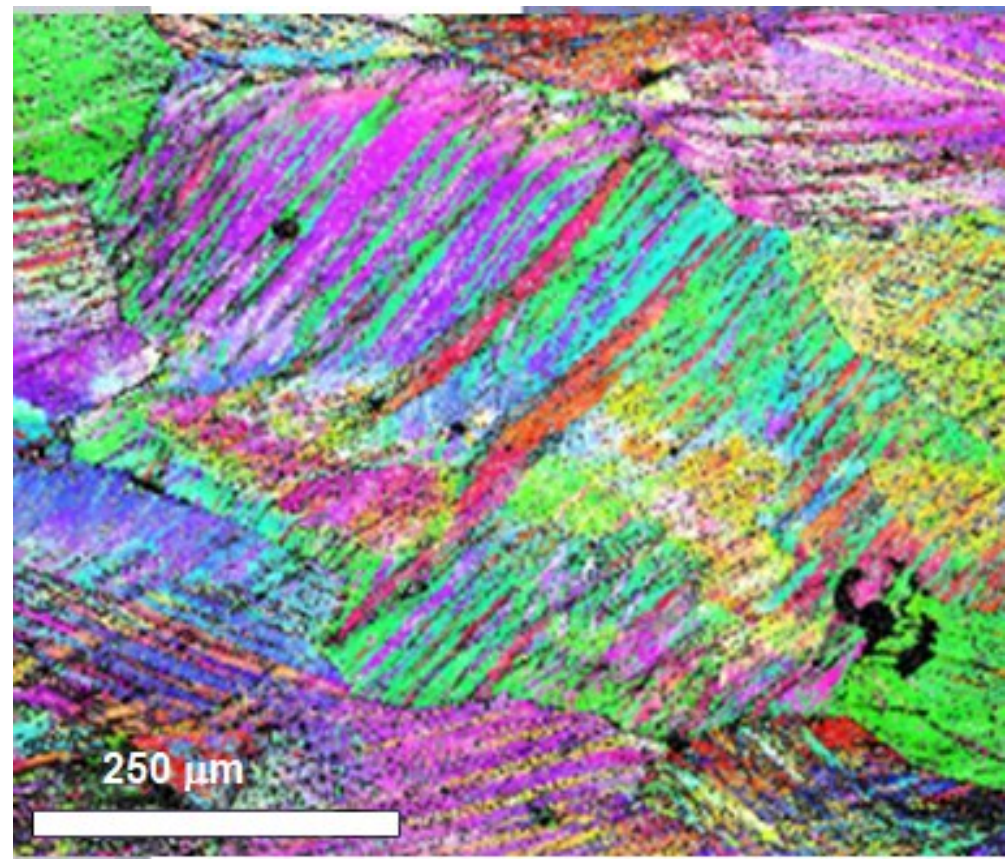


Tabela 12 - Densidade de maclas e do espaçamento entre as maclas para o aço Hadfield sem refino.

\begin{tabular}{|c|c|c|}
\hline Medidas & $\begin{array}{c}\text { Densidade de maclas } \\
(\text { maclas por } \mu \mathrm{m})\end{array}$ & $\begin{array}{c}\text { Espaçamento entre as maclas } \\
(\mu \mathrm{m})\end{array}$ \\
\hline 1 & $22 \pm 4$ & $18 \pm 3$ \\
\hline 2 & $27 \pm 4$ & $12 \pm 3$ \\
\hline 3 & $18 \pm 4$ & $17 \pm 3$ \\
\hline 4 & $14 \pm 4$ & $22 \pm 3$ \\
\hline 5 & $16 \pm 4$ & $23 \pm 3$ \\
\hline Média: & 19 & 18 \\
\hline
\end{tabular}

Tabela 13 - Densidade de maclas e do espaçamento entre as maclas para o aço Hadfield refinado

\begin{tabular}{|c|c|c|}
\hline Medidas & $\begin{array}{c}\text { Densidade de maclas } \\
(\text { maclas por } \mu \mathrm{m})\end{array}$ & $\begin{array}{c}\text { Espaçamento entre as maclas } \\
(\mu \mathrm{m})\end{array}$ \\
\hline 1 & $37 \pm 5$ & $7 \pm 5$ \\
\hline 2 & $44 \pm 5$ & $6 \pm 5$ \\
\hline 3 & $29 \pm 5$ & $20 \pm 5$ \\
\hline 4 & $35 \pm 5$ & $9 \pm 5$ \\
\hline 5 & $28 \pm 5$ & $16 \pm 5$ \\
\hline Média: & 35 & 12 \\
\hline
\end{tabular}

Os corpos de prova rompidos no ensaio de tração também foram cortados na direção paralela à superfície de fratura, com o objetivo de verificar a quantidade de grãos presentes na seção resistente para cada condição (aço Hadfield sem refino e refinado). Na microestrutura do aço Hadfield refinado (63b) observa-se presença de maclas de deformação nos grãos austeníticos, 0 que não ocorre para a micrografia do aço Hadfield sem refino (figura 63-a). A seção resistente do aço Hadfield sem refino apresenta apenas 4 grãos na superfície de tração, enquanto que a amostra de aço Hadfield refinado apresenta grãos característicos de um policristal. 
Figura 63 - Micrografia do corpo de prova de aço Hadfield rompido no ensaio de tração, seção paralela à superfície de fratura, ataque químico com Nital 3\%; (a) aço Hadfield sem refino, aumento original ; (b) aço Hadfield refinado, aumento de 50x. Microscópio óptico.

(a)

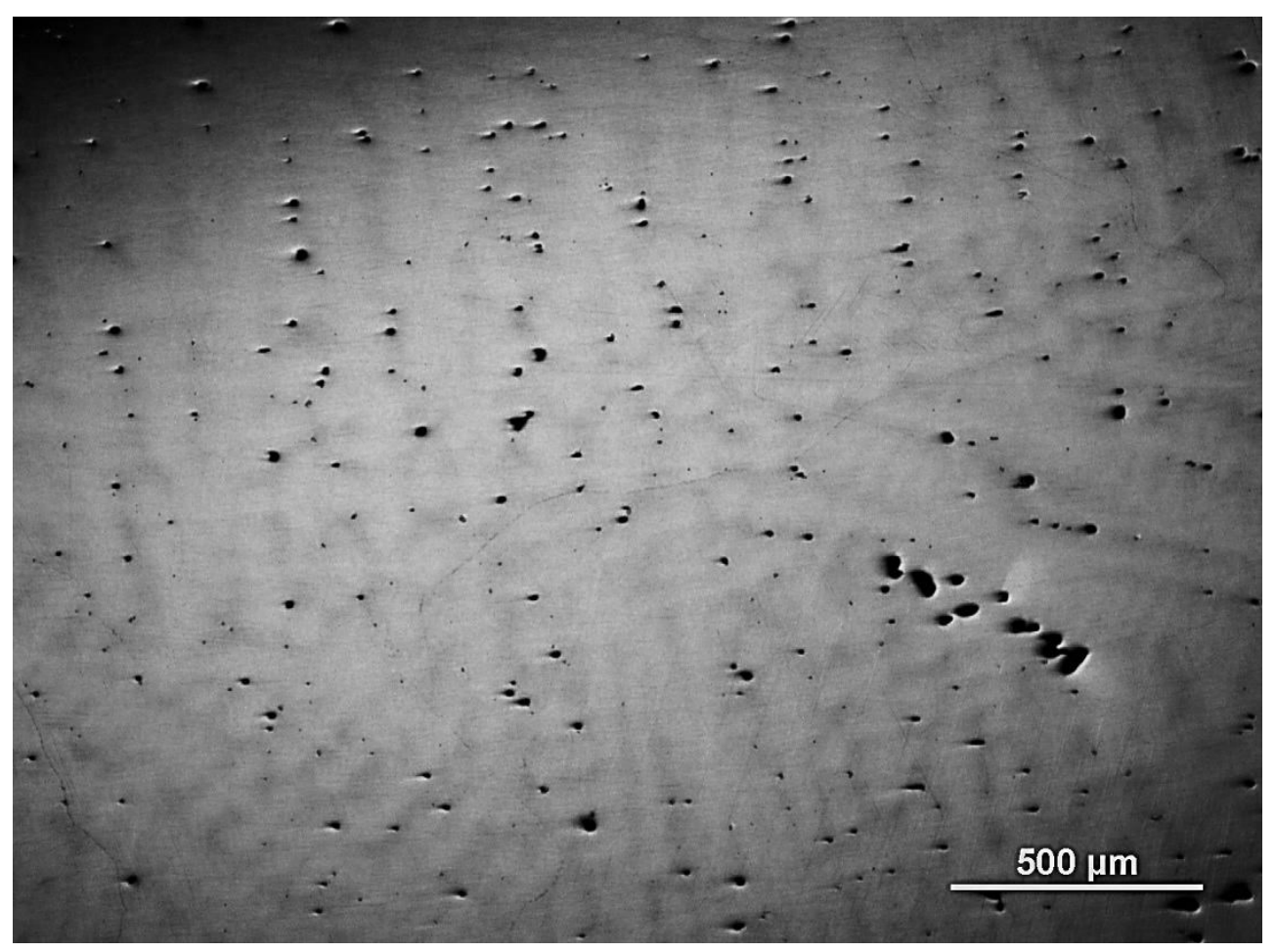

(b)

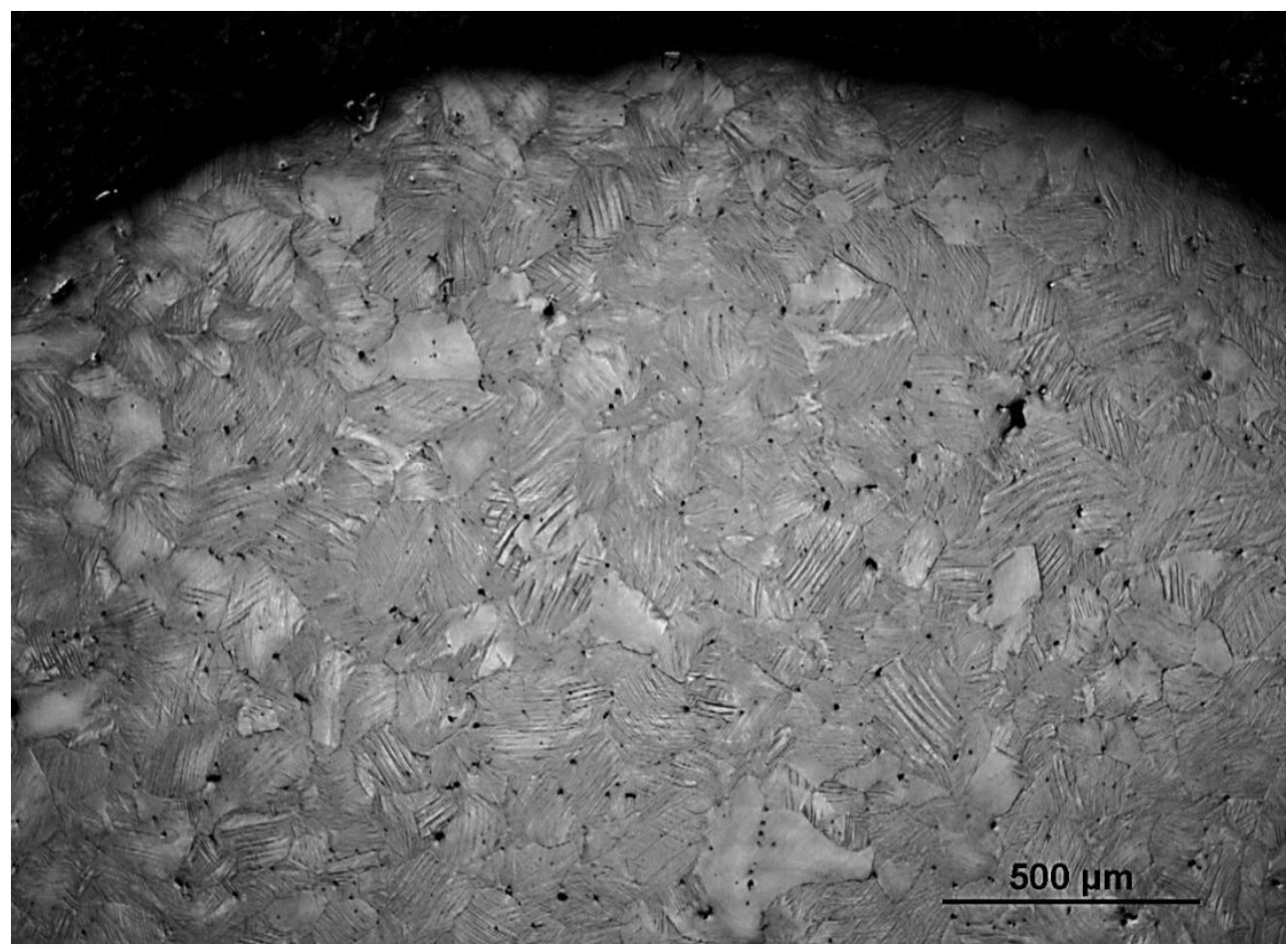




\subsection{RESULTADOS DO ENSAIO DE IMPACTO DAS AMOSTRAS SOLUBILIZADAS}

A fração de microporosidades presentes nos corpos de prova para o ensaio de impacto Charpy extraídos do "bloco" e "keel block" foi determinado a partir da técnica de metalografia quantitativa e microscopia óptica. Os resultados do ensaio de impacto Charpy do aço Hadfield sem refino e refinado são apresentados a seguir. A microestrutura da superfície de fratura dos corpos de prova rompidos no ensaio de impacto foi analisada pela LUPA, microscopia óptica e microscopia eletrônica de varredura.

\subsubsection{Fração de microporosidades presentes nos corpos de prova extraídos do "bloco" e "keel block"}

A tabela 14 mostra os valores da fração pontual e em área das microporosidades presentes nos corpos de prova de aço Hadfield sem refino e refinado extraídos do "bloco" e "keel block". Observa-se que o aço Hadfield refinado possui fração em área de microporosidades 53\% (para o bloco) e 47\% (para o "keel block") maiores e fração pontual de microporosidades $67 \%$ (para o bloco) e $31 \%$ (para o "keel block") maiores em comparação com o aço Hadfield sem refino. A fração pontual é maior do que a fração em área de microporosidades para os dois materiais (aço Hadfield sem refino e refinado) e os dois tipos de amostras (bloco x "keel block"). A maioria das microporosidades presentes no interior da peça possuem pequeno diâmetro (o diâmetro das microporosidades varia de 2 a $1 \mu \mathrm{m}$ ).

As figuras 64-a, 64-b, 65-a e 65-b mostram a microestrutura geral das amostras de aço Hadfield sem refino e refinado extraídos do "keel block" e do bloco. Observa-se qualitativamente que as amostras extraídas do "keel block" apresentam menor quantidade de micro porosidades do que as amostras extraídas do bloco. A comparação das micrografias das figuras 64 e 65 mostra que as amostras de aço Hadfield sem refino apresentam menor quantidade de microporosidades do que as amostras de aço Hadfield refinado, tanto para as 
amostras extraídas do bloco quanto do "keel block". Em geral, o tamanho das microporosidades é maior para o aço Hadfield refinado do que o aço Hadfield sem refino.

Tabela 14 - Fração pontual e em área e microporosidades presentes nos corpos de prova de aço Hadfield sem refino e refinado extraídos do "bloco" e "keel block".

\begin{tabular}{|c|c|c|c|}
\hline Material & $\begin{array}{c}\text { Tipo de } \\
\text { amostra }\end{array}$ & $\begin{array}{c}\text { Fração pontual de } \\
\text { microporosidades }\end{array}$ & $\begin{array}{c}\text { Fração em área de } \\
\text { microporosidades }\end{array}$ \\
\hline $\begin{array}{c}\text { Aço Hadfield sem } \\
\text { refino }\end{array}$ & bloco & $6,4 \pm 0,7$ & $3,4 \pm 0,5$ \\
\cline { 2 - 4 } & Keel block & $3,6 \pm 0,5$ & $0,9 \pm 0,4$ \\
\hline $\begin{array}{c}\text { Aço Hadfield } \\
\text { refinado com Hf }\end{array}$ & bloco & $10,7 \pm 0,9$ & $5,2 \pm 0,7$ \\
\cline { 2 - 4 } & Keel block & $4,7 \pm 0,8$ & $1,7 \pm 0,8$ \\
\hline
\end{tabular}

Figura 64 - Microporosidades presentes no aço Hadfield sem refino, 100x, sem ataque químico.

(a) Corpo de prova extraído do "Keel block" e (b) Corpo de prova extraído do bloco.

(a)

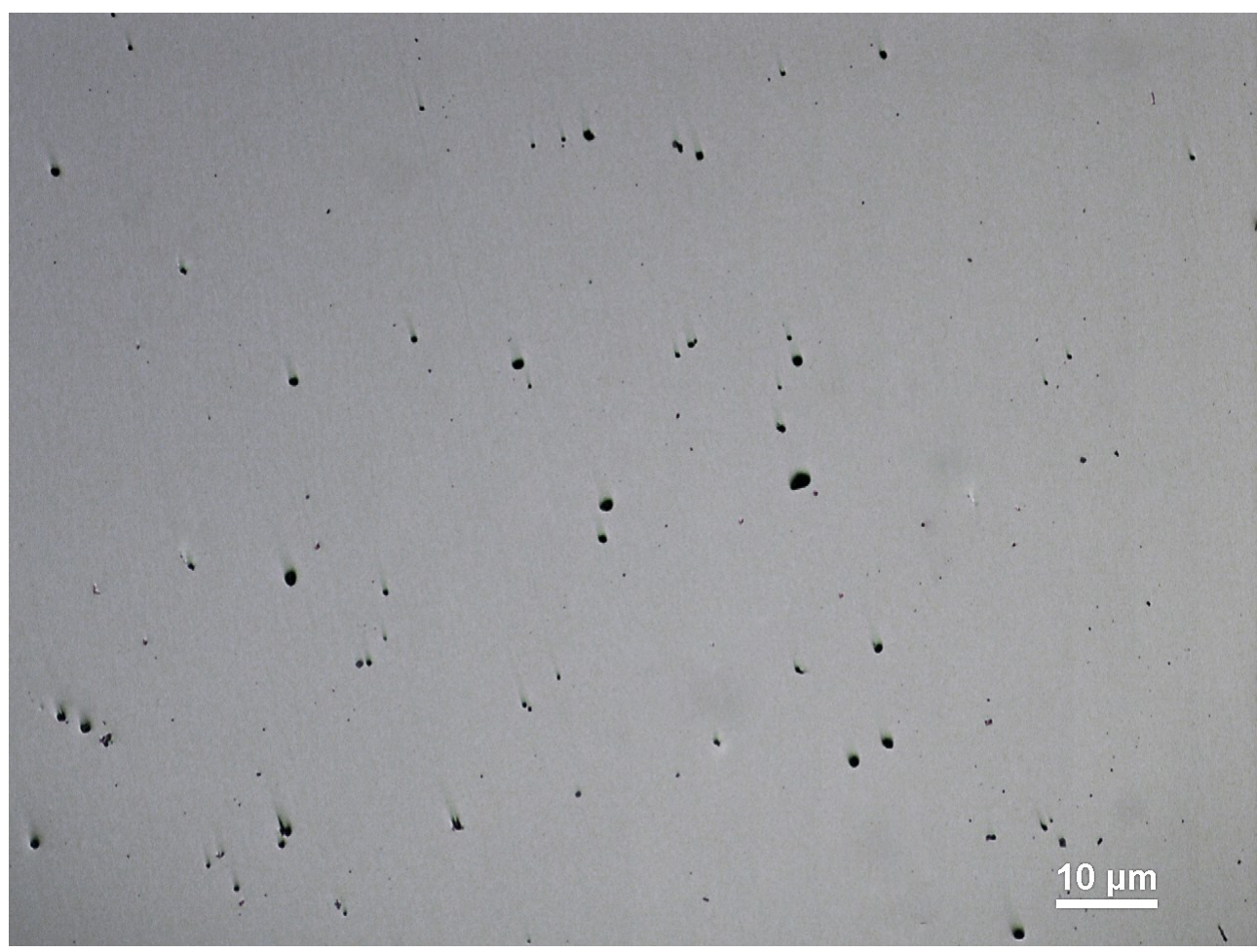


(b)

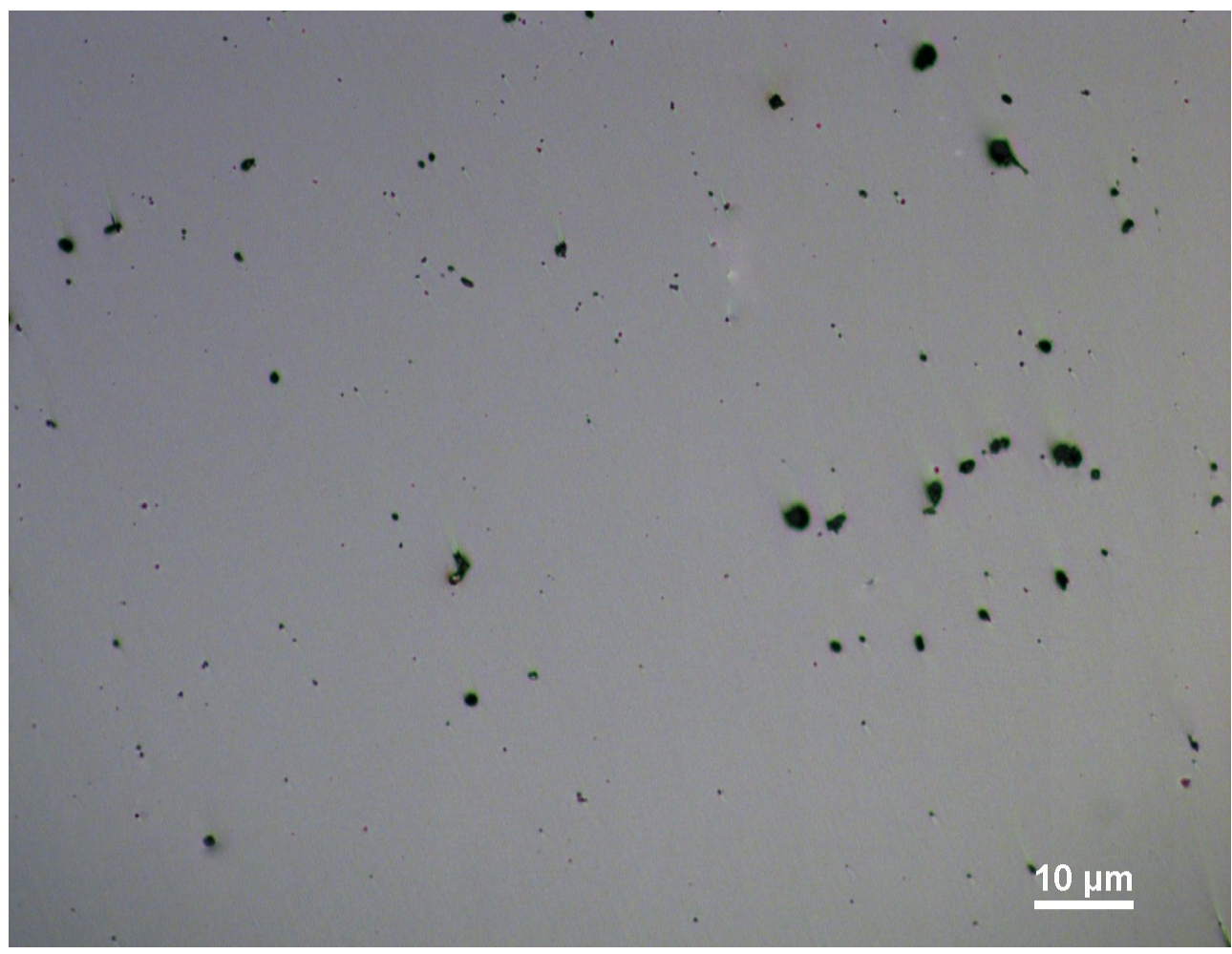

Figura 65 - Microporosidades presentes no aço Hadfield refinado, 100x, sem ataque químico.

(a) Corpo de prova extraído do "Keel block" e (b) Corpo de prova extraído do bloco.

(a)

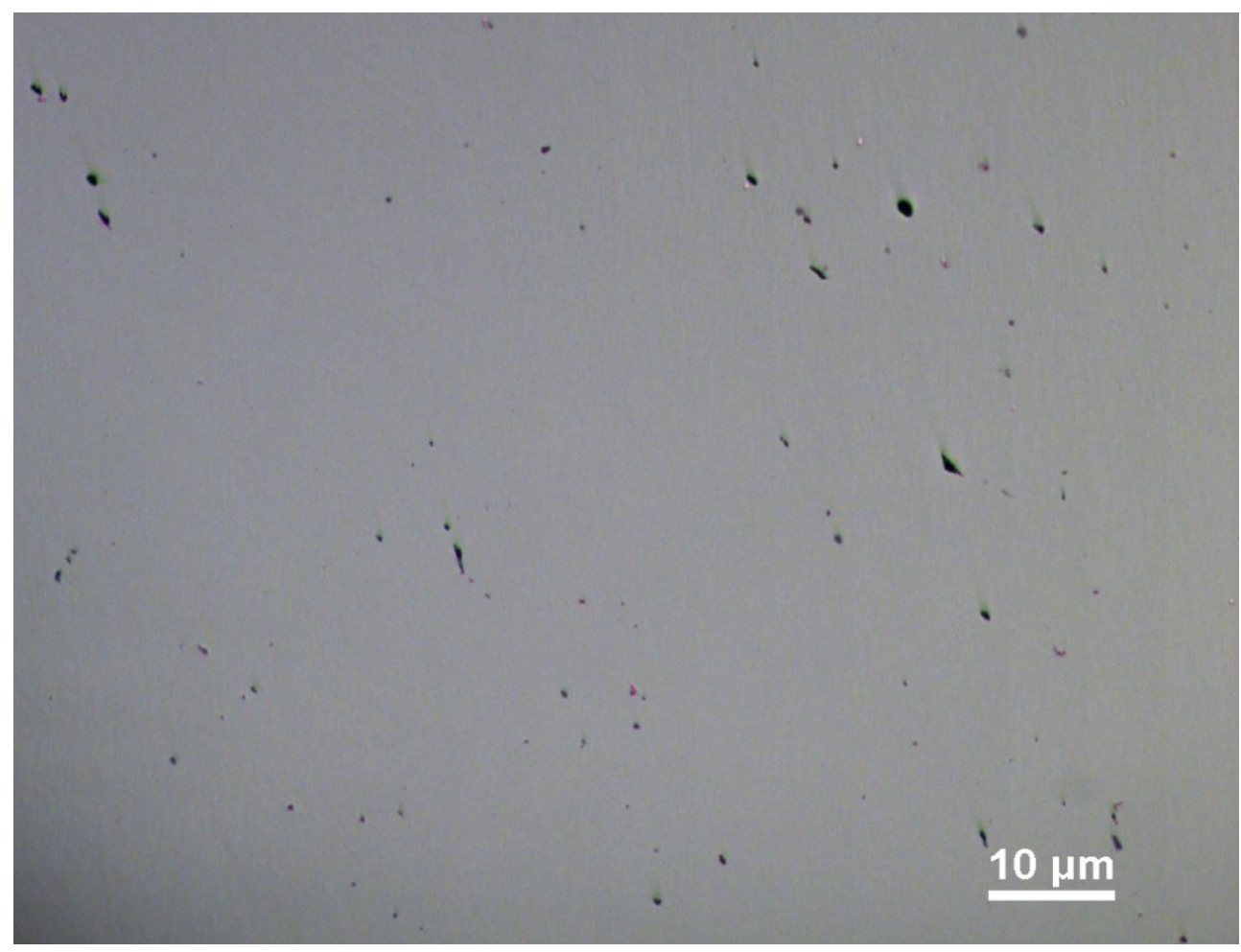


(b)

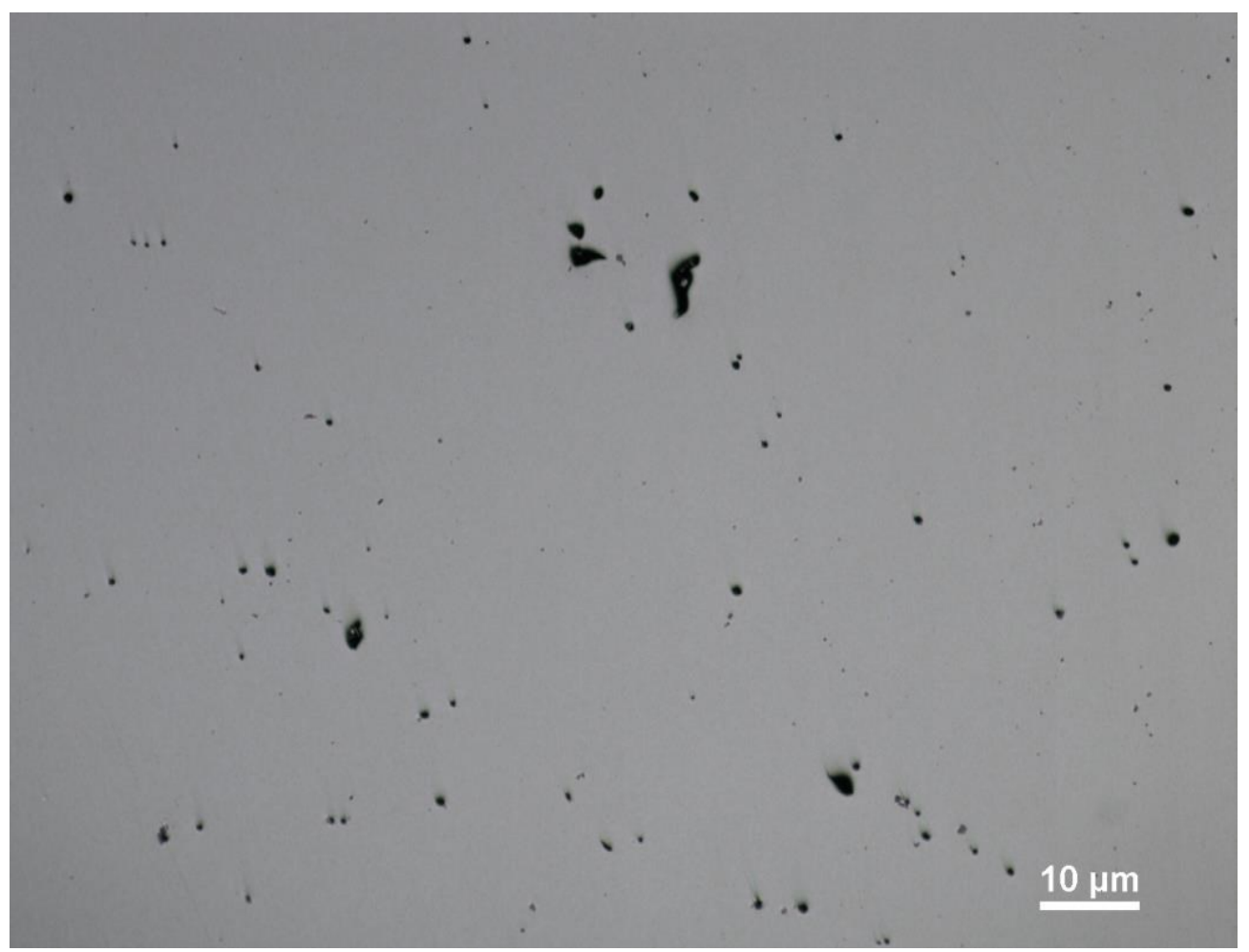

\subsubsection{Resultados do ensaio de impacto Charpy das amostras solubilizadas}

As tabelas 15 e 16 mostram os valores da energia absorvida no impacto das amostras de aço Hadfield nas duas condições estudadas (sem refino e refinada com Hf) para os corpos de prova extraídos do bloco e "keel block". Os corpos de prova de cada condição (sem refino e refinado) extraídos do bloco apresentaram valores semelhantes de energia absorvida no impacto com baixo desvio padrão (13 para o aço Hadfield refinado e 25 para o aço Hadfield sem refino), com exceção dos corpos de prova 3 da condição sem refino e 2 da refinada com Hf que possuíram valores $16 \%$ e $13 \%$ mais baixos do que a média. Os corpos de prova de cada condição (sem refino e refinado) extraídos do "keel block" também apresentaram valores semelhantes de energia absorvida no impacto com baixo desvio padrão (9 para o aço Hadfield refinado e 3 para o aço Hadfield sem refino. No entanto, o desvio padrão é menor para os corpos de prova retirados do "keel block" em comparação com os corpos de prova retirados do bloco. 
Os resultados mostram que o aço Hadfield sem refino (amostra retirada do "keel block") possui energia absorvida no impacto $\left(156 \mathrm{~J} / \mathrm{cm}^{2}\right)$ de acordo com a faixa encontrada na literatura (110-169 J/cm²) (KUYUCAK, 2001), e o resultado obtido para o corpo de prova extraído do bloco apresenta o valor da energia absorvida no impacto $\left(156 \mathrm{~J} / \mathrm{cm}^{2}\right)$ maior do que os valores presentes na literatura (KUYUCAK, 2001). Este fato pode estar relacionado com a maior eficiência do tratamento térmico na solubilização dos carbonetos interdendríticos, que tendem a reduzir a tenacidade do material (KUYUCAK, 2001). Kuyucak (KUYUCAK, 2001) obteve a energia absorvida no impacto de $180 \mathrm{~J} / \mathrm{cm}^{2}$, semelhante ao aço Hadfield sem refino estudado $\left(176 \mathrm{~J} / \mathrm{cm}^{2}\right)$, para o aço Hadfield com composição química de $1,2 \%$ de carbono, $13 \%$ de manganês e 1\% de silício (de acordo com a norma ASTM A128-grau B3) submetido ao tratamento térmico de solubilização á temperatura de $1200^{\circ} \mathrm{C}$ por 1 hora.

O valor médio da energia absorvida foi reduzido em 33\% com o refino do tamanho de grão considerando-se os corpos de prova extraídos do bloco. Em contraste, observa-se que para as amostras extraídas do "keel block", a energia absorvida no impacto aumentou em $13 \%$ com a redução do tamanho de grão. A energia absorvida no impacto está relacionada com o início da formação de uma trinca e a propagação dessa trinca no material, dessa forma, a presença de microporosidades no material facilitam a propagação das trincas. As amostras extraídas do bloco apresentaram elevada fração em área de microporosidades, tendo influência nos resultados obtidos no ensaio de impacto.

Tabela 15 - Energia absorvida no ensaio de impacto $\left(\mathrm{J} / \mathrm{cm}^{2}\right)$ do aço Hadfield sem refino.

\begin{tabular}{|c|c|c|}
\hline $\begin{array}{c}\text { Corpo de prova } \\
\text { (cp) }\end{array}$ & $\begin{array}{c}\left.\text { Energia absorvida (J/cm }{ }^{2}\right)- \\
\text { bloco }\end{array}$ & $\begin{array}{c}\left.\text { Energia absorvida (J/cm }{ }^{2}\right)- \\
\text { “keel block” }\end{array}$ \\
\hline 1 & $198 \pm 25$ & $154 \pm 3$ \\
\hline 2 & $183 \pm 25$ & $154 \pm 3$ \\
\hline 3 & $148 \pm 25$ & $161 \pm 3$ \\
\hline Média: & 176 & 156 \\
\hline
\end{tabular}


Tabela 16 - Energia absorvida no ensaio de impacto $\left(\mathrm{J} / \mathrm{cm}^{2}\right)$ do aço Hadfield refinado com $0,1 \%$ $\mathrm{Hf}$.

\begin{tabular}{|c|c|c|}
\hline $\begin{array}{c}\text { Corpo de prova } \\
\text { (cp) }\end{array}$ & $\begin{array}{c}\text { Energia absorvida (J/cm ) } \\
\text { bloco }\end{array}$ & $\begin{array}{c}\text { Energia absorvida (J/cm }{ }^{2} \text { )- } \\
\text { "keel block" }\end{array}$ \\
\hline 1 & $127 \pm 13$ & $167 \pm 9$ \\
\hline 2 & $102 \pm 13$ & $193 \pm 9$ \\
\hline 3 & $123 \pm 13$ & $178 \pm 9$ \\
\hline Média: & 117 & 179 \\
\hline
\end{tabular}

\subsubsection{Fractografias dos corpos de prova rompidos no ensaio de impacto Charpy}

Nas figuras 66 e 67 observam-se as macrografias da superfície de fratura dos materiais de estudo (aço Hadfield sem refino e refinado) extraídos do "keel block" e do bloco, solubilizados e rompidos no ensaio de impacto. A superfície de fratura do aço Hadfield sem refino é rugosa (figuras 66-a e 67-b), característica de fraturas dúcteis, enquanto que a superfície de fratura do aço Hadfield refinado, apresenta menor rugosidade do que o aço Hadfield sem refino (figuras 67-a e 67-b). As superfícies de fratura do aço Hadfield sem refino e refinado mostram estruturas dendríticas com comprimentos de aproximadamente $2000 \mu \mathrm{m}$ e $500 \mu \mathrm{m}$ respectivamente, indicando a presença de fratura interdendrítica, podendo estar relacionada com a presença de microporosidades na microestrutura desse material. 
Figura 66 - Superfície de fratura após o ensaio de impacto do cp1 do aço Hadfield sem refino

(a) e refinado com $\mathrm{Hf}$ (b) extraídos do bloco. Aumento original de 10x. Exame em lupa.

(a)

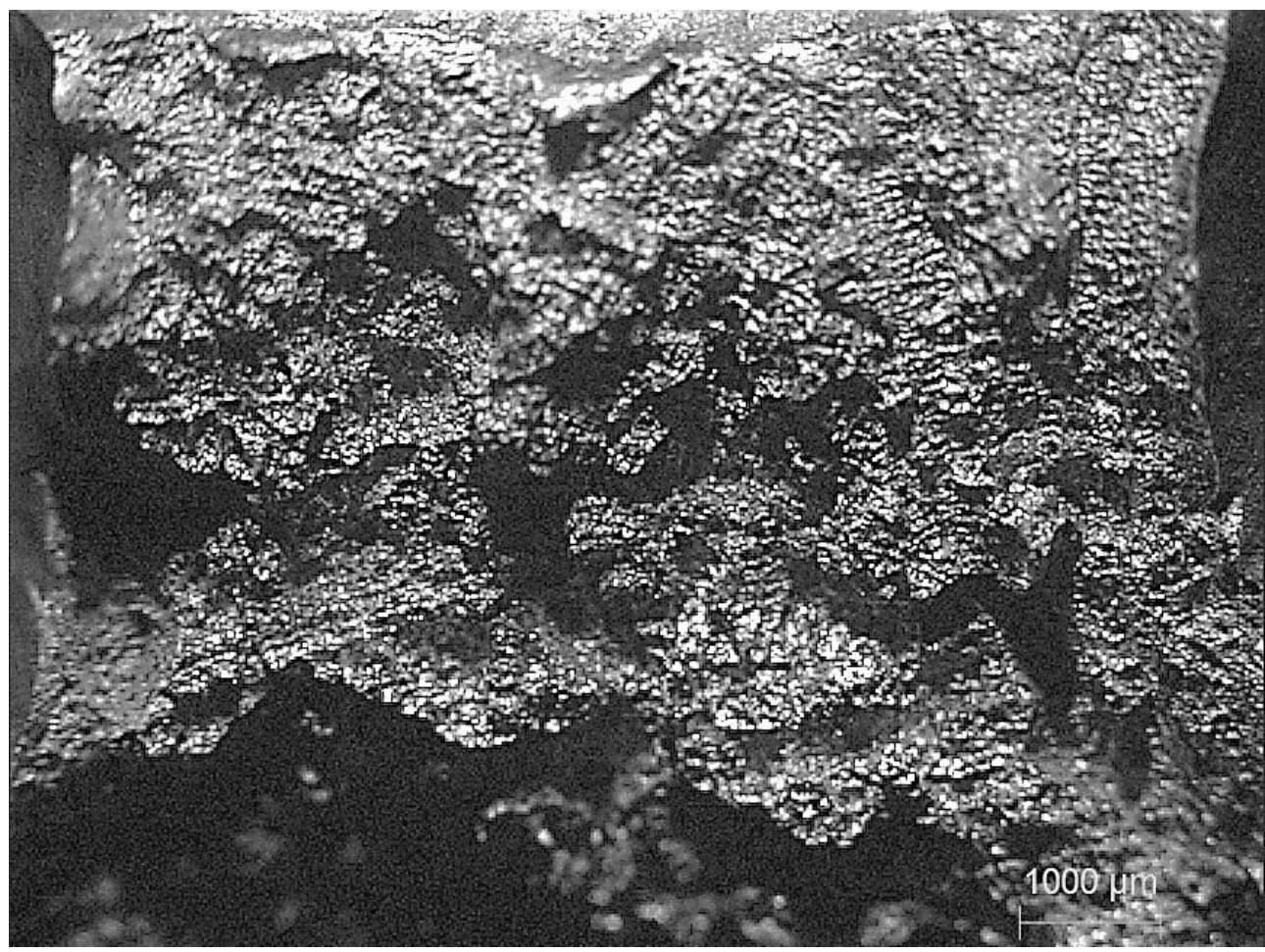

(b)

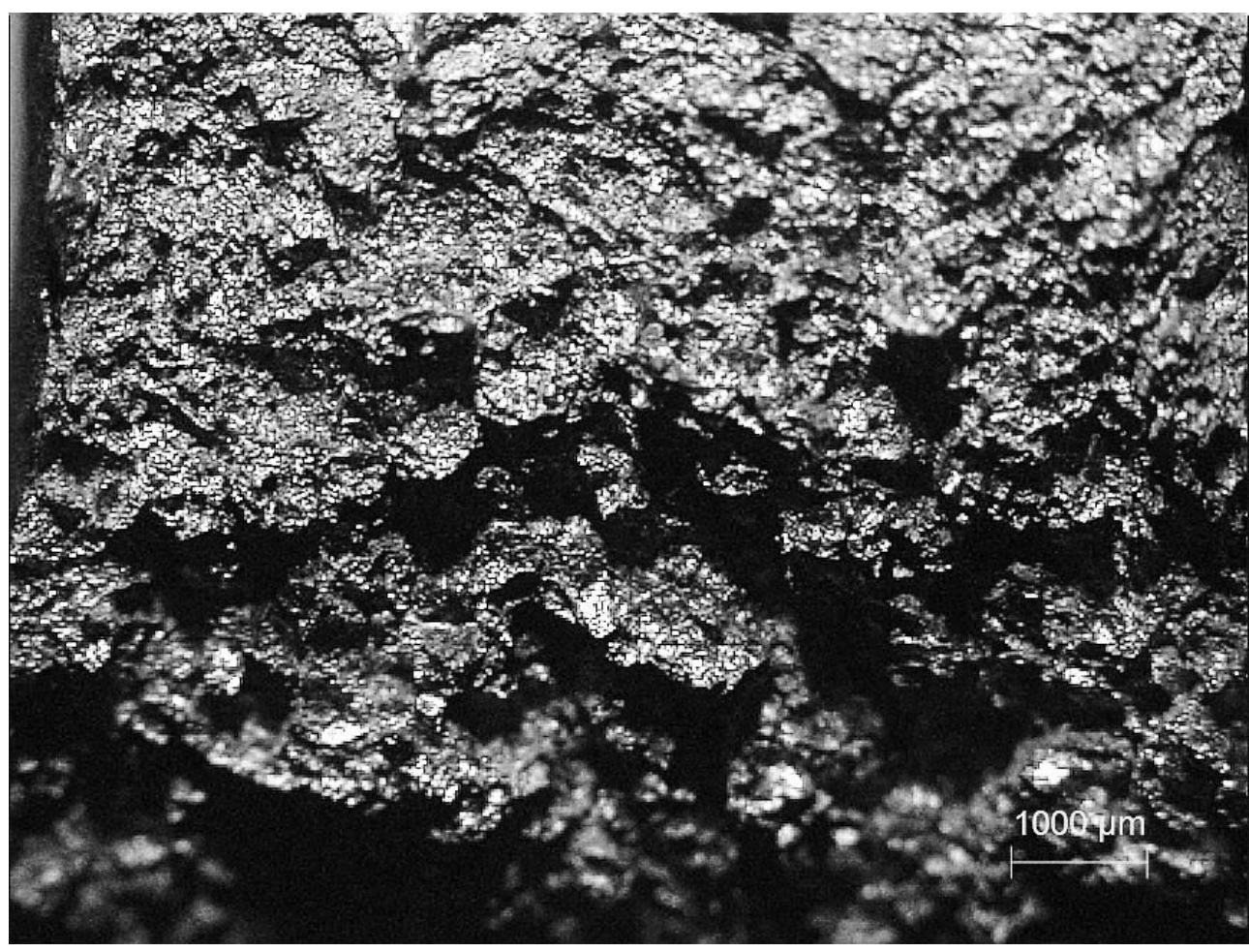


Figura 67 - Superfície de fratura após o ensaio de impacto do cp1 do aço Hadfield sem refino (a) e refinado com $\mathrm{Hf}$ (b), amostra extraída do "keel block". Aumento original de 10x. Exame em lupa.

(a)

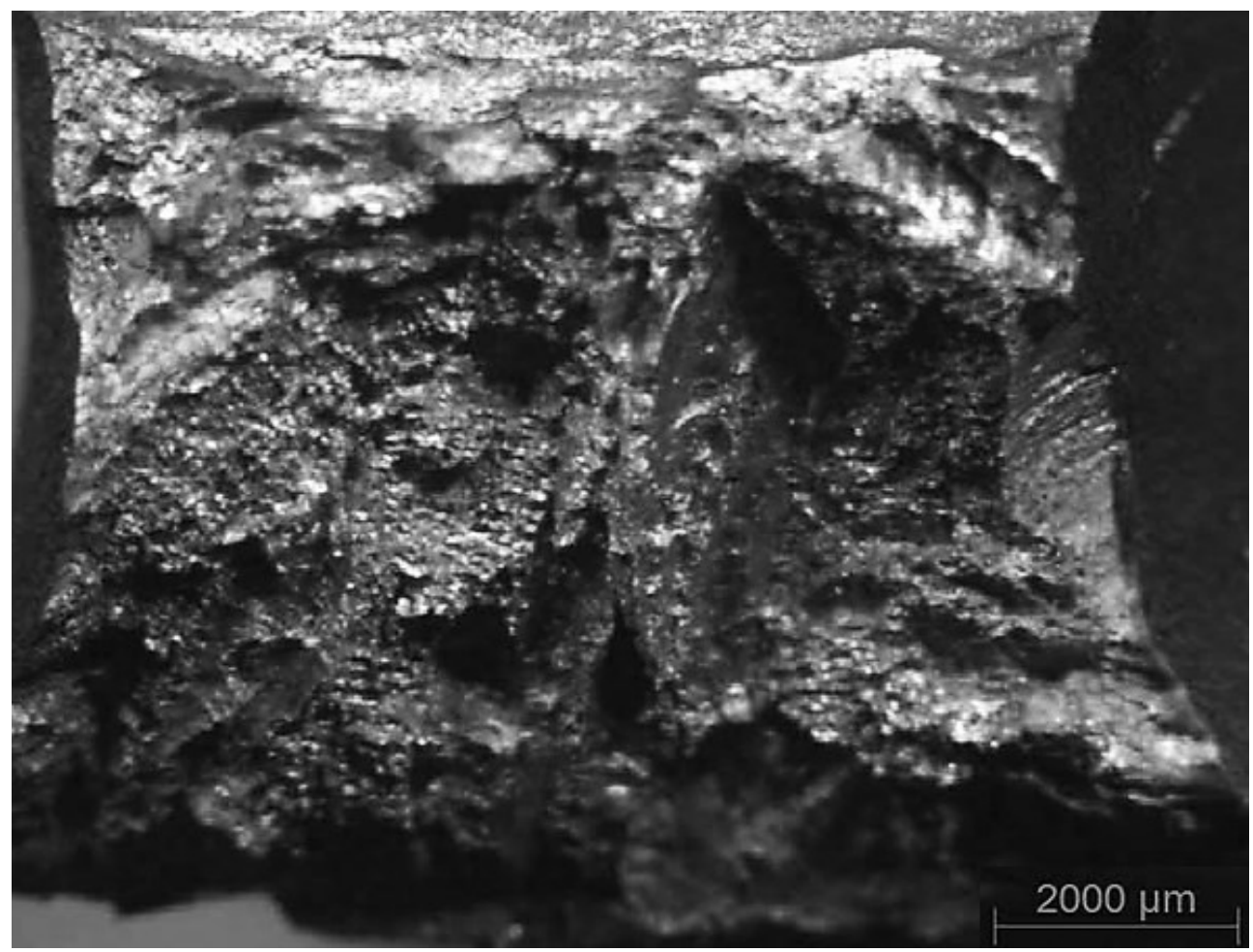

(b)

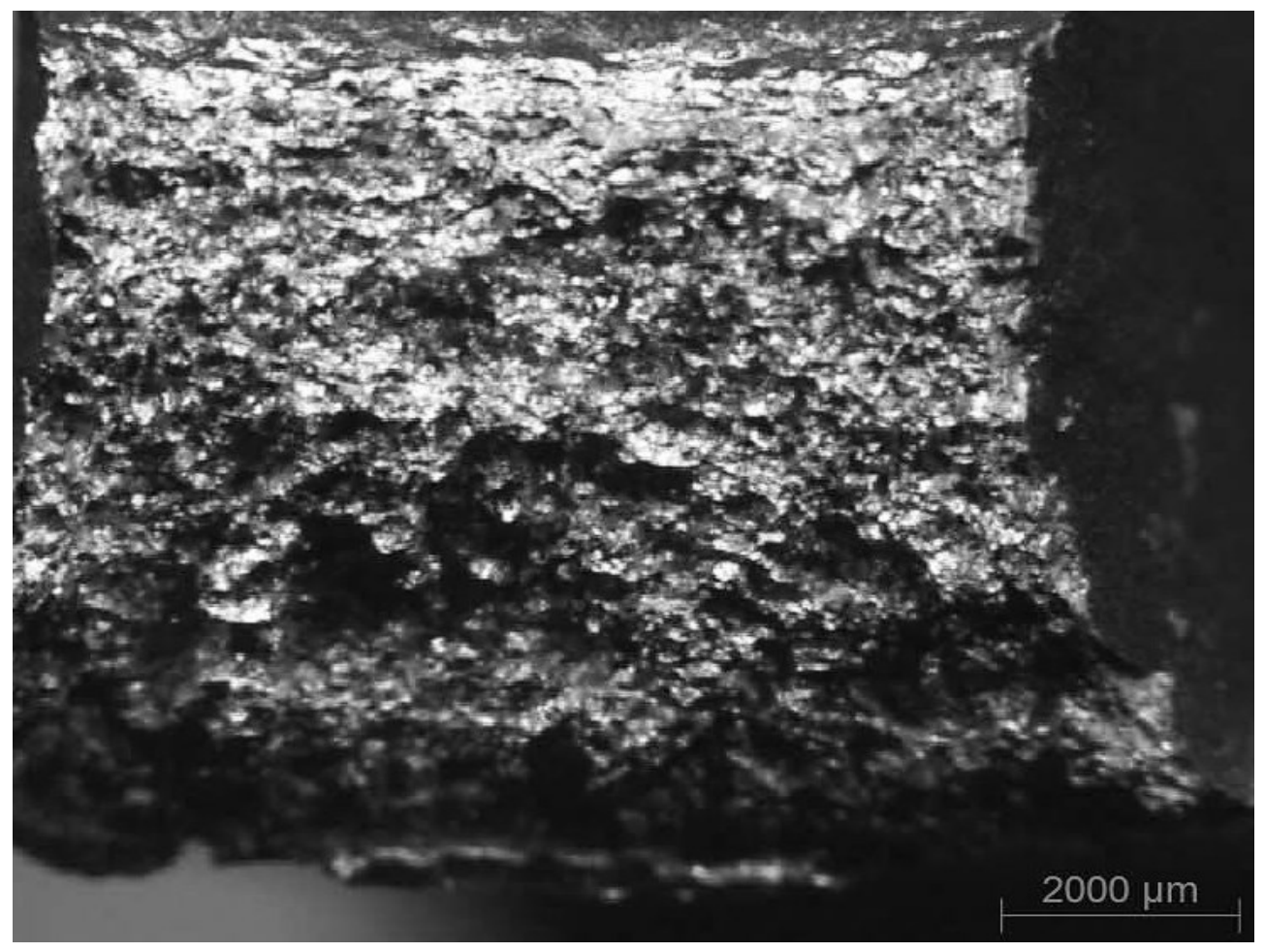


As superfícies de fratura dos corpos de prova extraídos do "keel block" foram analisadas por microscopia eletrônica de varredura (figuras 68 a 69). No aço Hadfield sem refino (figuras 68-a e 68-b) observa-se a formação de alvéolos característicos da fratura dúctil com diâmetro de aproximadamente $3 \mu \mathrm{m}$, e possíveis maclas de deformação com comprimento em torno de 500 $\mu \mathrm{m}$. Nas fractografias da amostra com tamanho de grão refinado (figuras 69-a e 69-b) observa-se a presença de micro alvéolos com diâmetro de $2 \mu \mathrm{m}$ e possíveis maclas de deformação com comprimento em torno de $50 \mu \mathrm{m}$. 0 diâmetro dos alvéolos formados durante a deformação plástica do aço Hadfield apresentam a mesma ordem de grandeza das inclusões presentes em sua microestrutura.

Figura 68 - Fractografias da superfície de fratura do aço Hadfield sem refino submetido ao ensaio de impacto (cps extraídos do "keel block"). (a) Maclas de deformação, aumento original de; (b) Fratura dúctil com a presença de alvéolos, aumento original de 2000x. Exame em MEV.

(a)

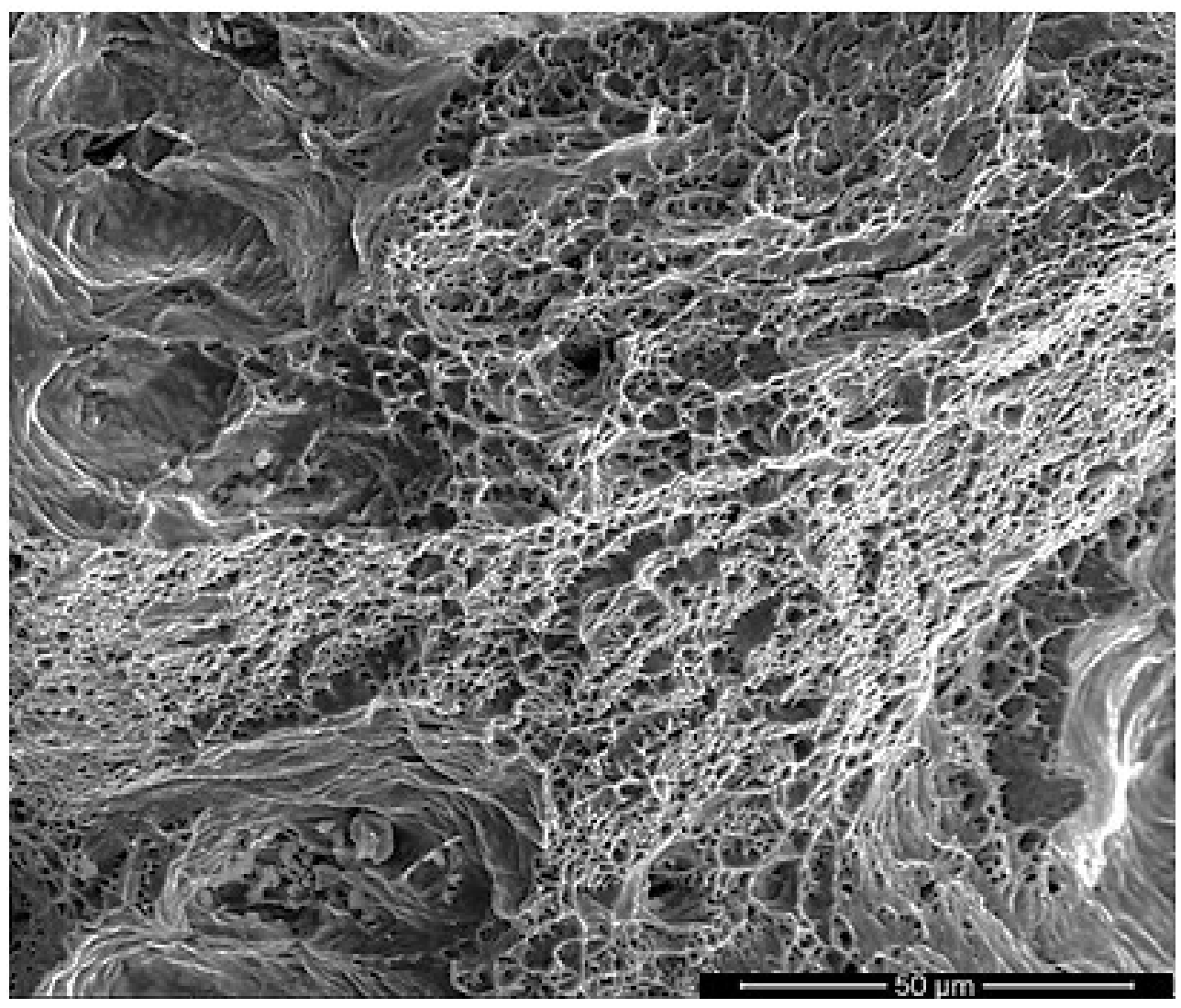


(b)

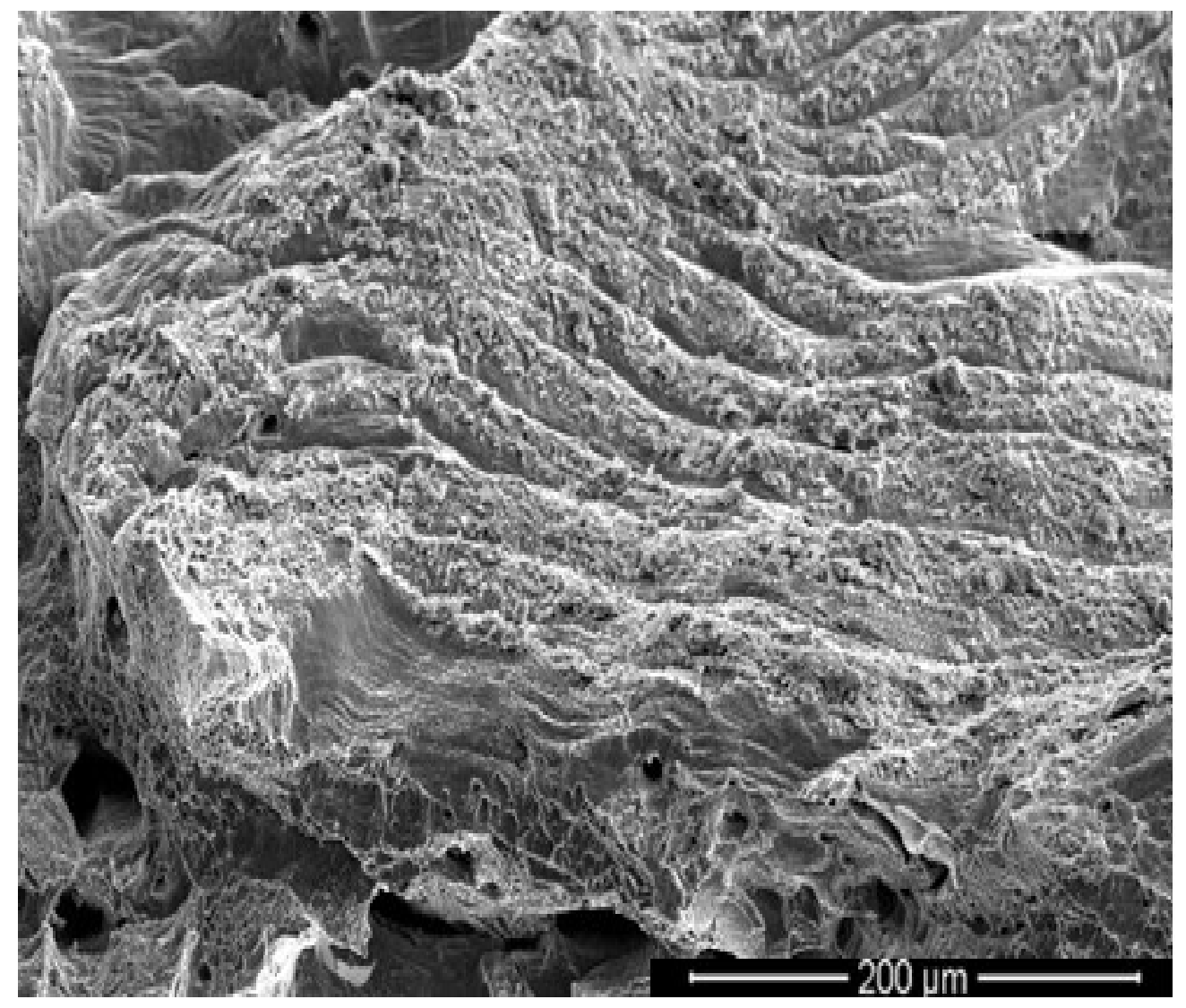


Figura 69 - Fractografias da superfície de fratura do aço Hadfield refinado submetido ao ensaio de impacto (cps extraídos do "keel block"). (a) Maclas de deformação, aumento original de 4000x; (b) Fratura dúctil com a presença de alvéolos, aumento original de 4000x. Exame em MEV.

(a)

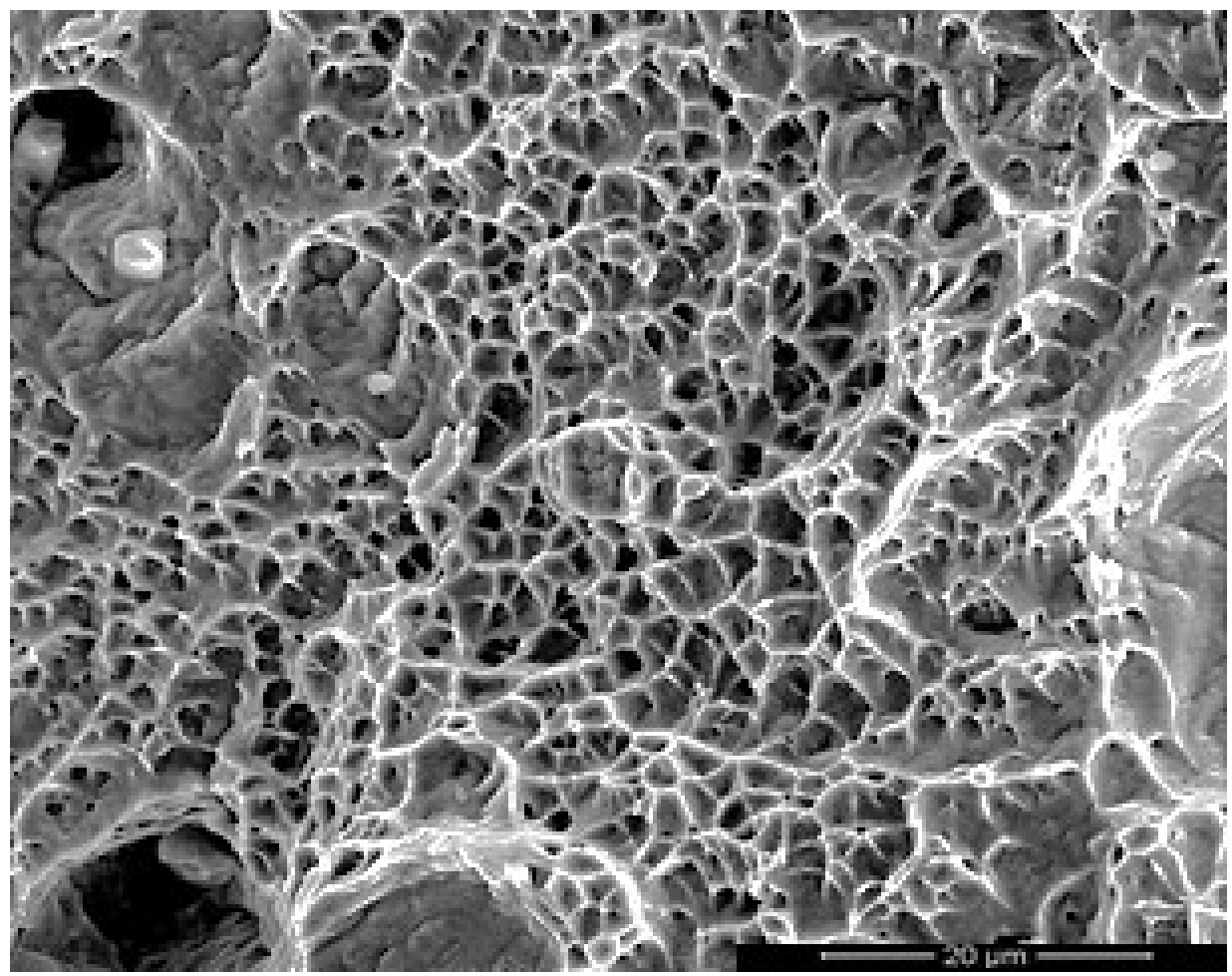

(b)

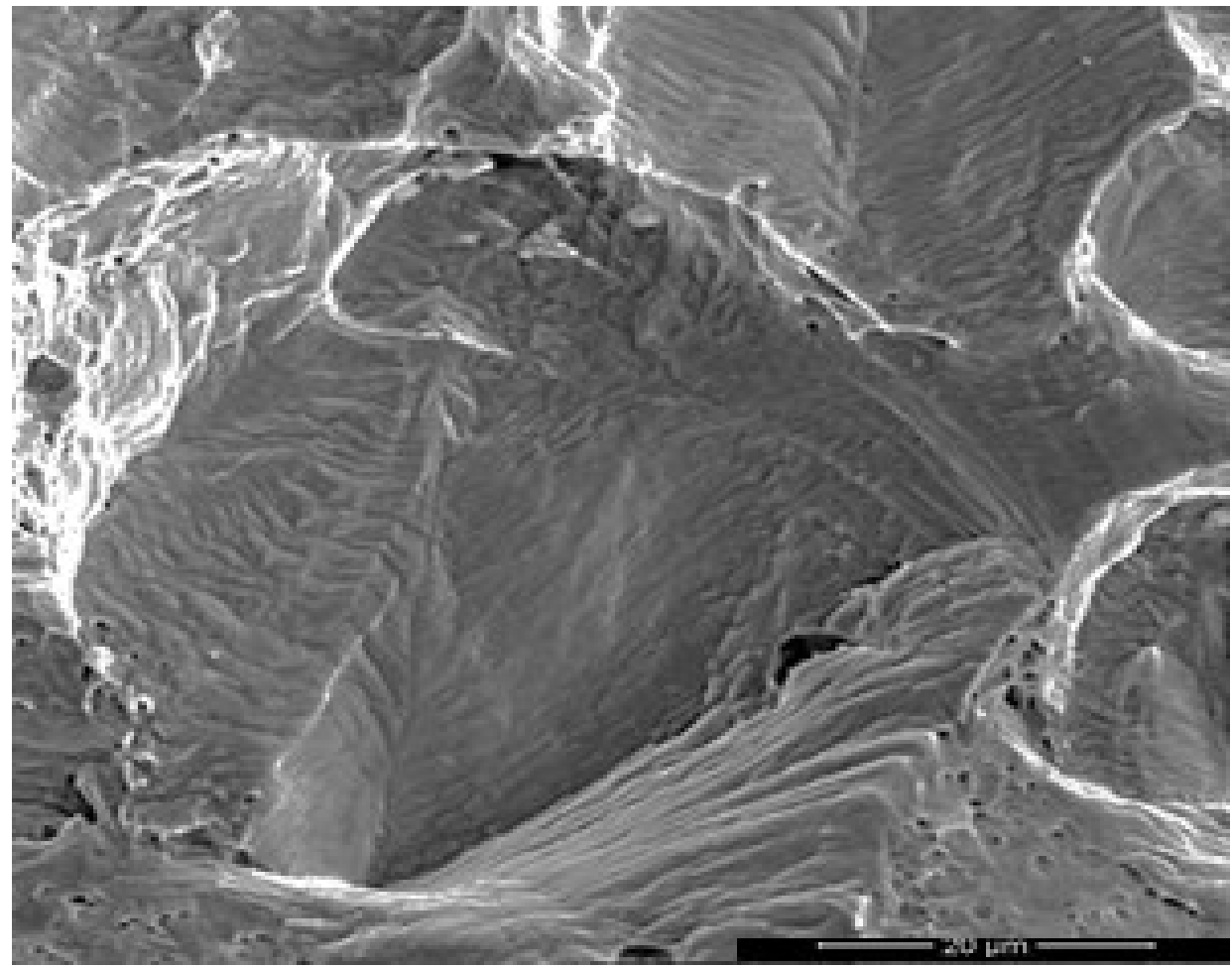


As fractografias do aço Hadfield refinado mostraram a presença de partículas de háfnio dentro dos micros alvéolos (figura 70-a) na imagem formada por elétrons retro-espalhados (figura 70-b), com composição química confirmada pelo espectro da microanálise química EDS (vide figura 66-c). Como mencionado anteriormente, nas simulações realizadas no Thermo-Calc para o aço Hadfield com adição de $0,1 \% \mathrm{Hf}$ (item 5.1), foram encontradas partículas de háfnio que podem atuar como sítios para a nucleação heterogênea da austenita durante a solidificação.

Figura 70 - Resultados de MEV da superfície de fratura do aço Hadfield com 0,1\% $\mathrm{Hf}$ submetido ao ensaio de impacto, utilizando (a) imagem de elétrons secundários, (b) imagem de elétrons retro-espalhados e (c) Espectro de microanálise química EDS da partícula encontrada nos resultados de MEV. Aumento original de 20000x.

(a)

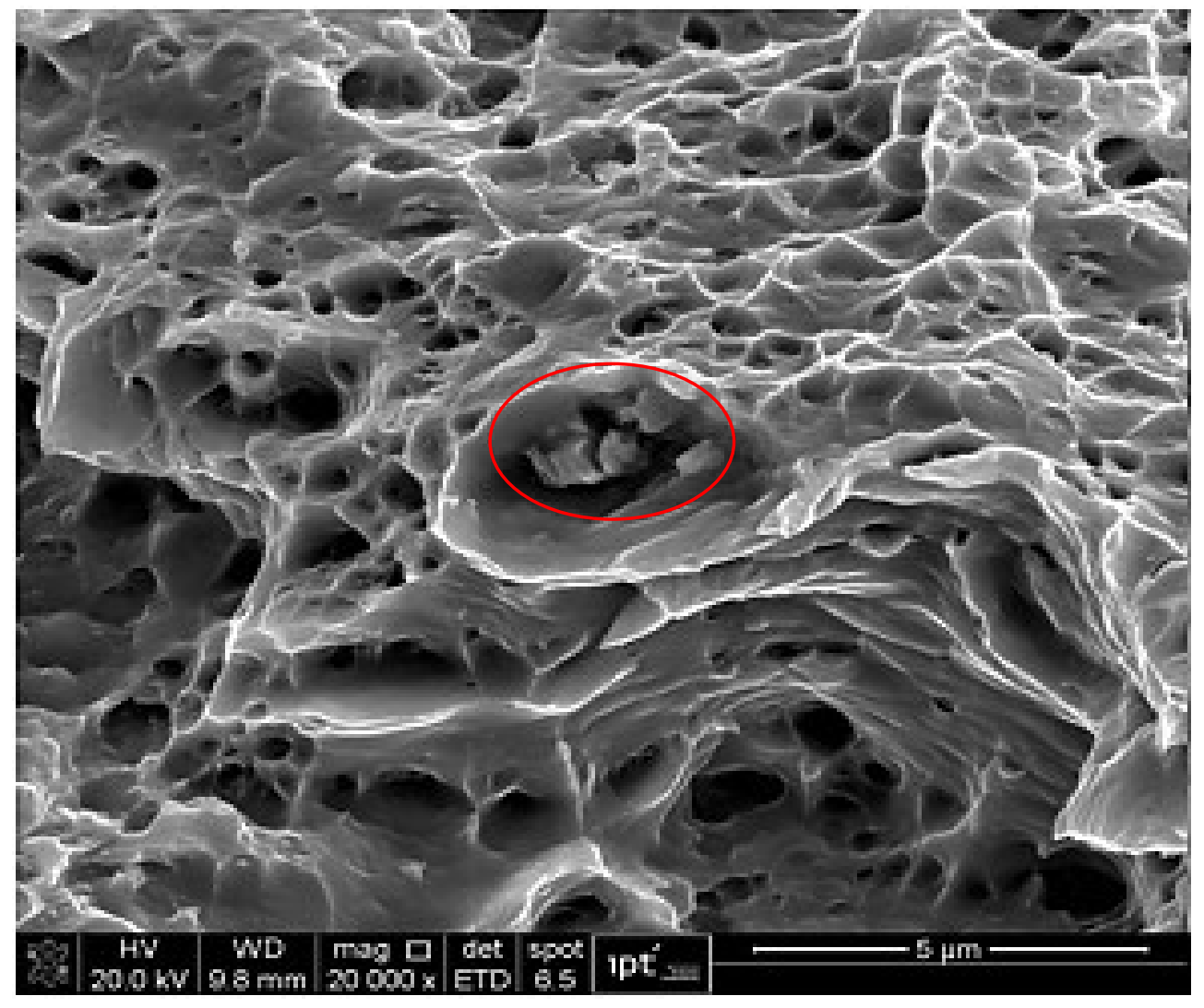


(b)

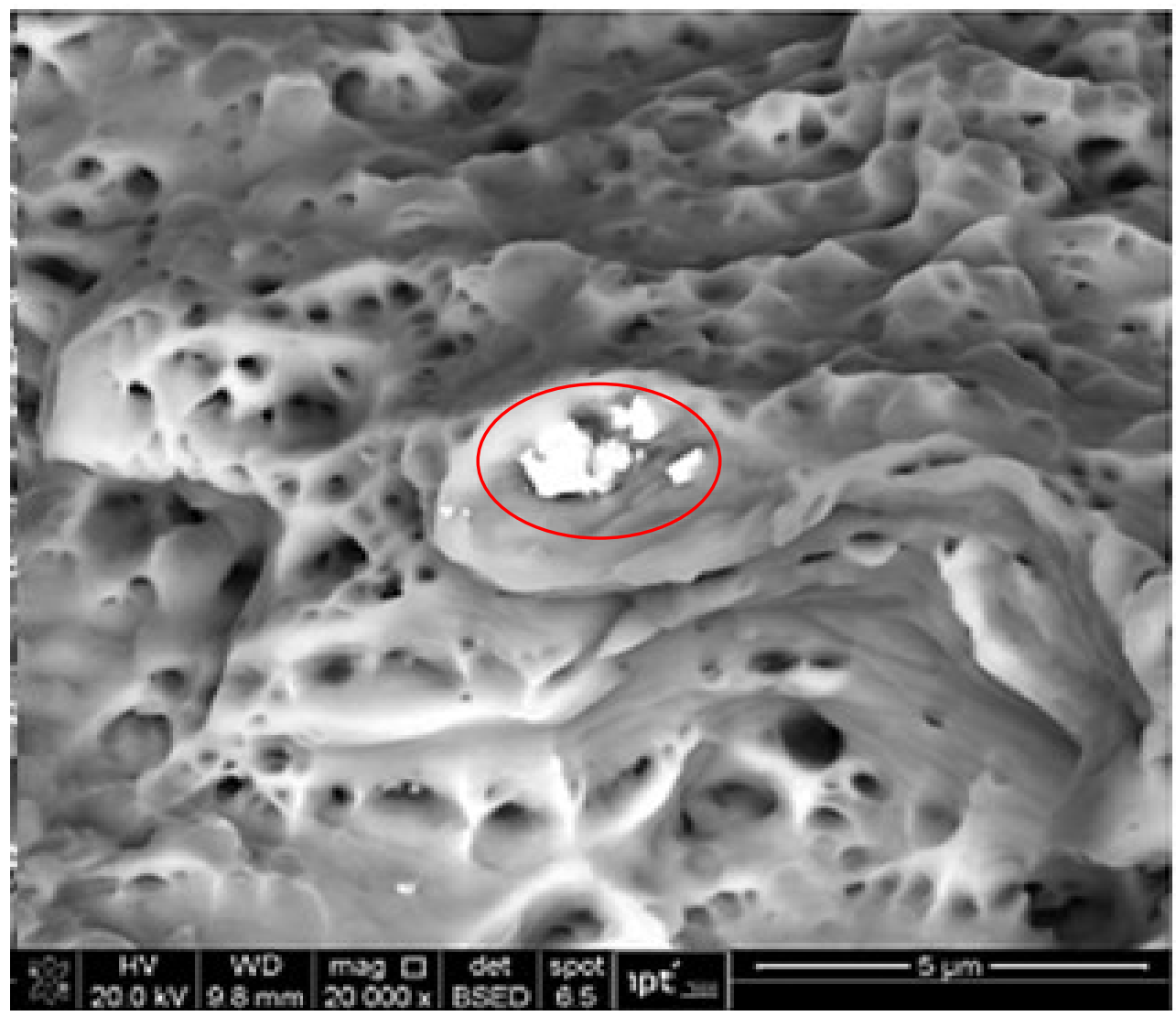

(c)

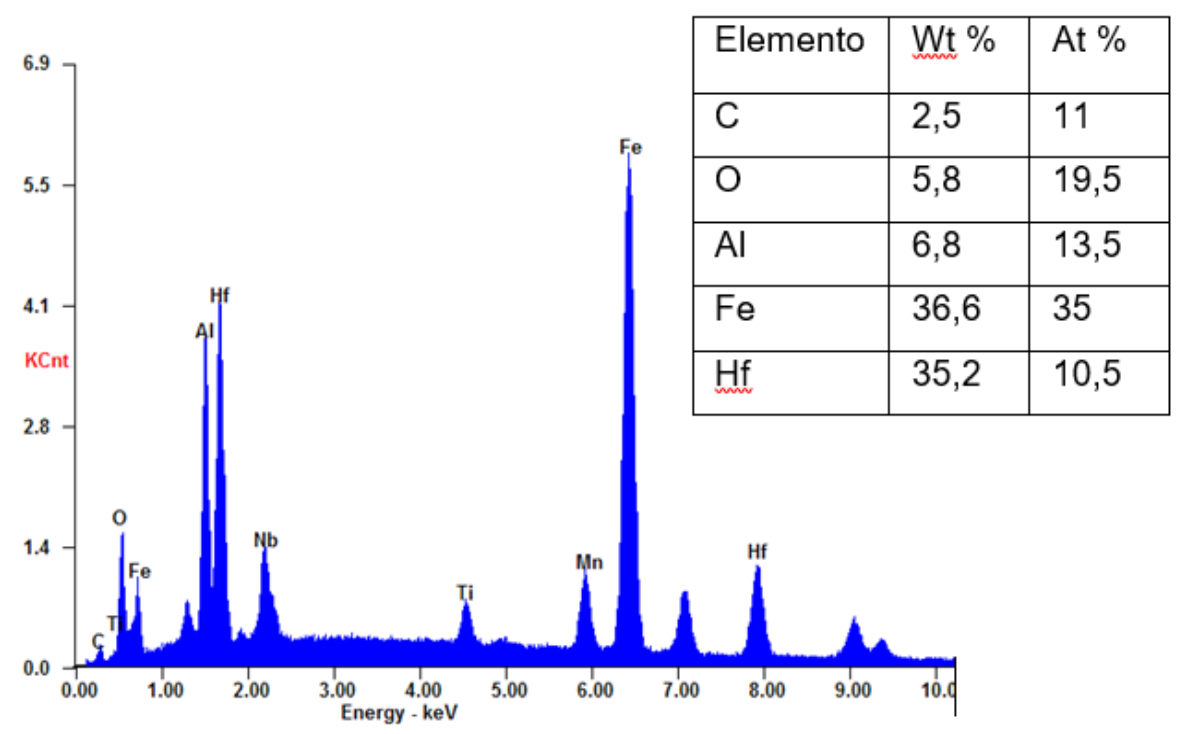


A superfície de fratura dos aços Hadfield sem refino e refinado (corpos de prova extraídos do bloco e do "keel block") após o ensaio de impacto foram seccionadas na transversal para caracterização microestrutural. A figura 71-a e 71-b sugere que a propagação das trincas ocorreu nas microporosidades presentes nas amostras de aço Hadfield sem refino e refinado, podendo estar relacionado com o valor mais baixo para a energia absorvida que os corpos de prova extraídos do bloco tiveram em comparação aos corpos de prova extraídos do "keel block".

As figuras 72 e 73 mostram a superfície de fratura dos corpos de prova extraídos do "keel block" e rompidos no ensaio de impacto para as duas condições (aço Hadfield sem refino e refinado). Observa-se a presença de regiões deformadas plasticamente próximas a região do entalhe, apresentando grãos austeníticos maclados tanto na condição sem refino quanto na refinada (figuras 72 e 73). As maclas de deformação presentes no aço Hadfield sem refino possuem $800 \mu \mathrm{m}$ de comprimento enquanto que as maclas de deformação presentes no aço Hadfield refinado possuem em torno de $500 \mu \mathrm{m}$. A análise da microestrutura do aço Hadfield refinado (vide tabelas 17 e 18) mostra que ele apresenta maior densidade de maclas (42 maclas por $\mu \mathrm{m}$ ) do que a amostra do aço Hadfield sem refino (24 maclas por $\mu \mathrm{m}$ ), vide figuras 72-b e 73-b. As tabelas 17 e 18 também mostram os valores do espaçamento entre maclas para o aço Hadfield sem refino e refinado. Observa-se que o valor do espaçamento entre as maclas é $35 \%$ menor para o aço Hadfield refinado em comparação com o aço Hadfield sem refino. 
Figura 71 - Micrografia do corpo de prova de aço Hadfield extraído do bloco, rompido no ensaio de impacto. (a) aço Hadfield sem refino, aumento original de 50x; (b) aço Hadfield refinado, aumento original de 100x. Microscópio óptico, sem ataque químico.

(a)

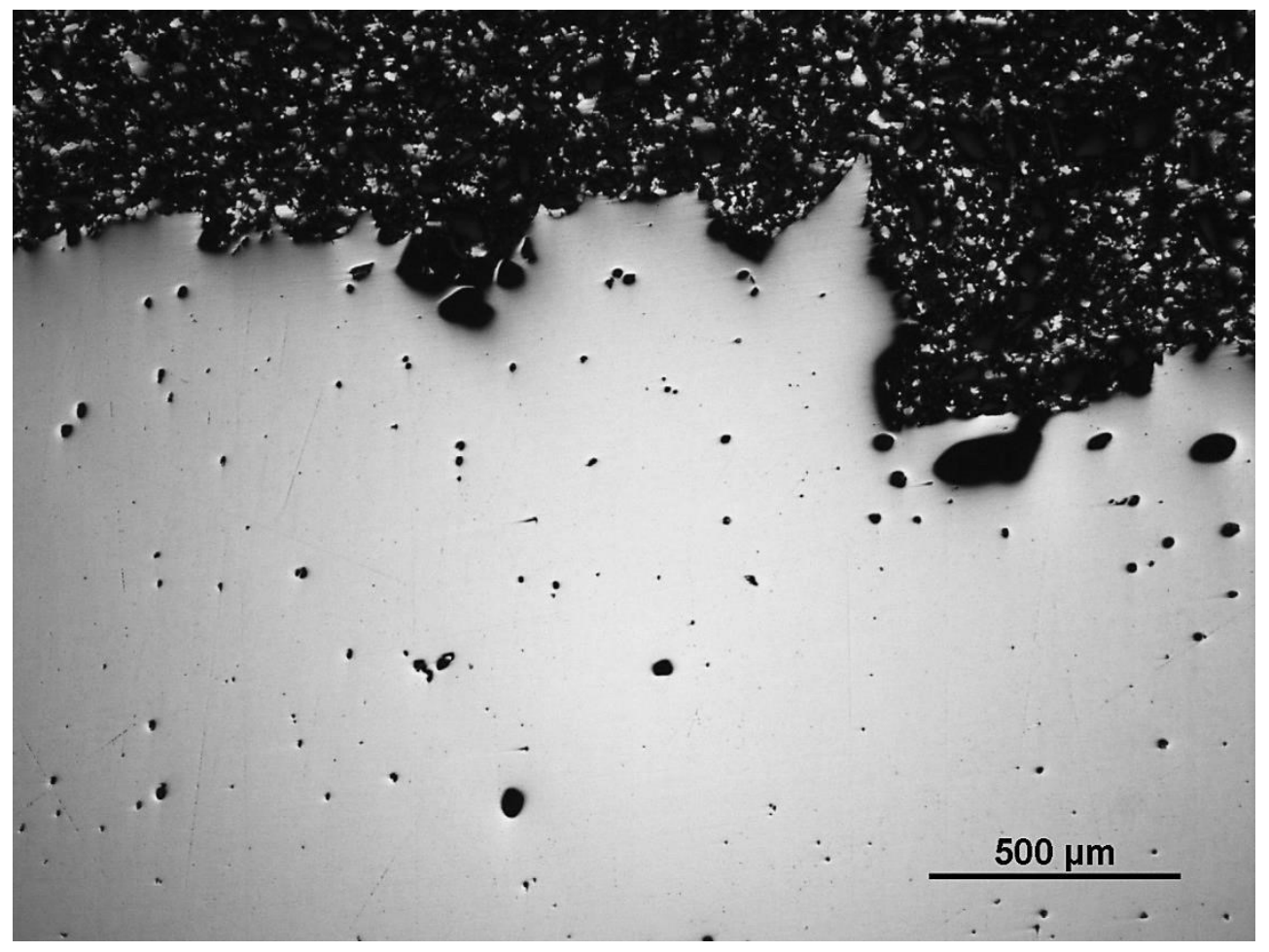

(b)

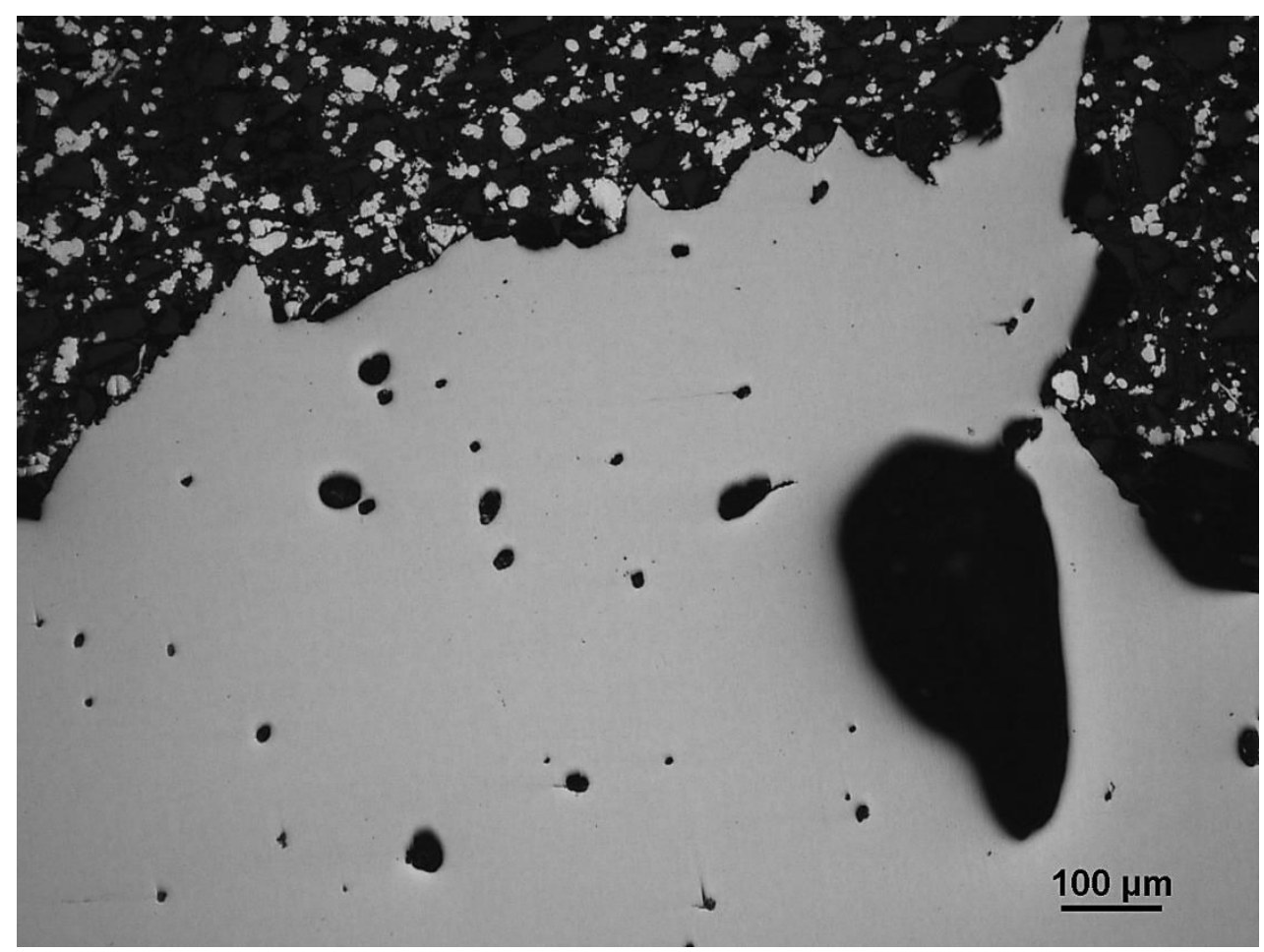


Figura 72 - Micrografia do corpo de prova de aço Hadfield sem refino rompido no ensaio de impacto. Ataque Nital 5\%. (a) Região próxima ao entalhe. Aumento original de 50x; (b) Detalhe dos grãos austeníticos. Aumento original de 200x. Microscópio óptico.

(a)

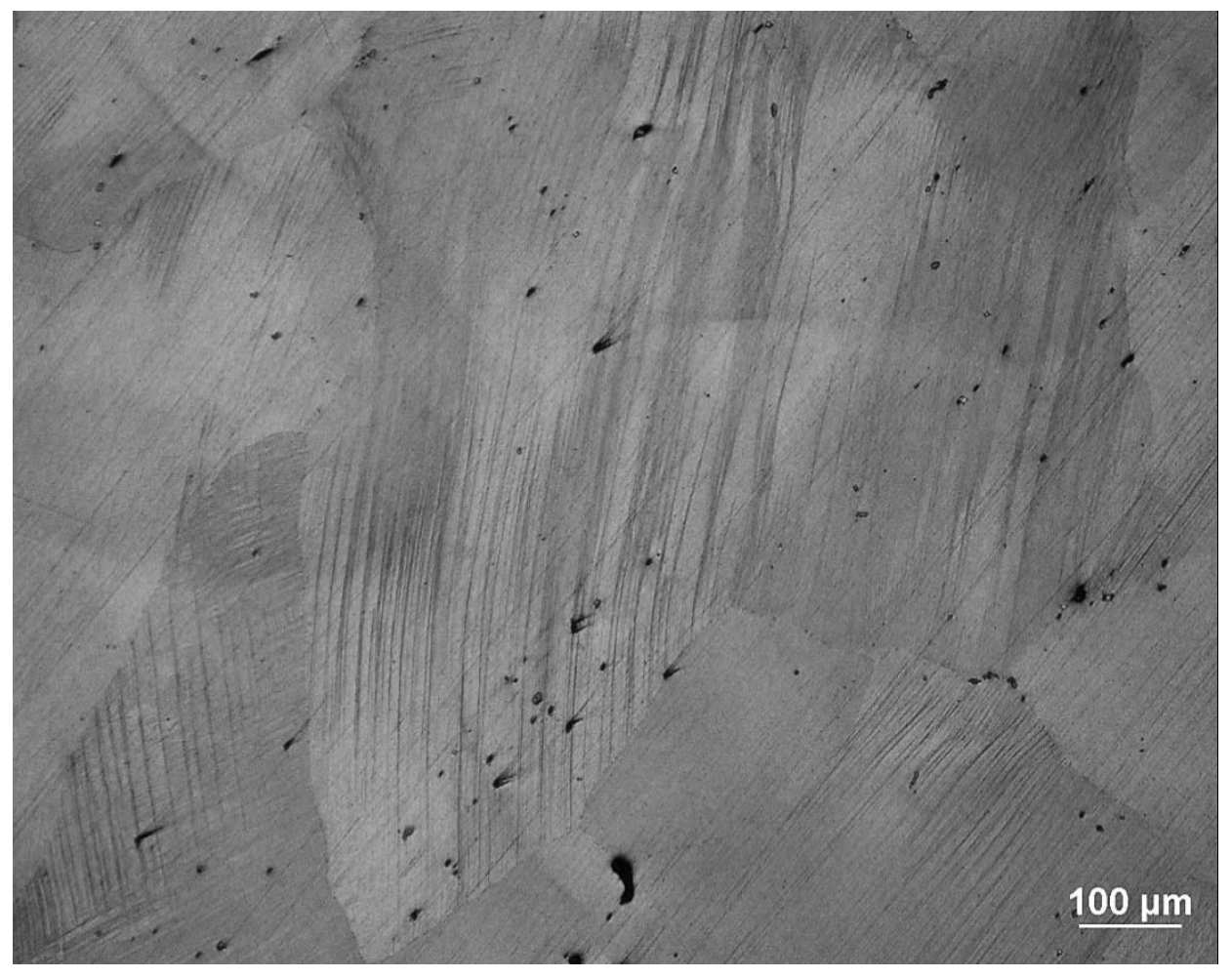

(b)

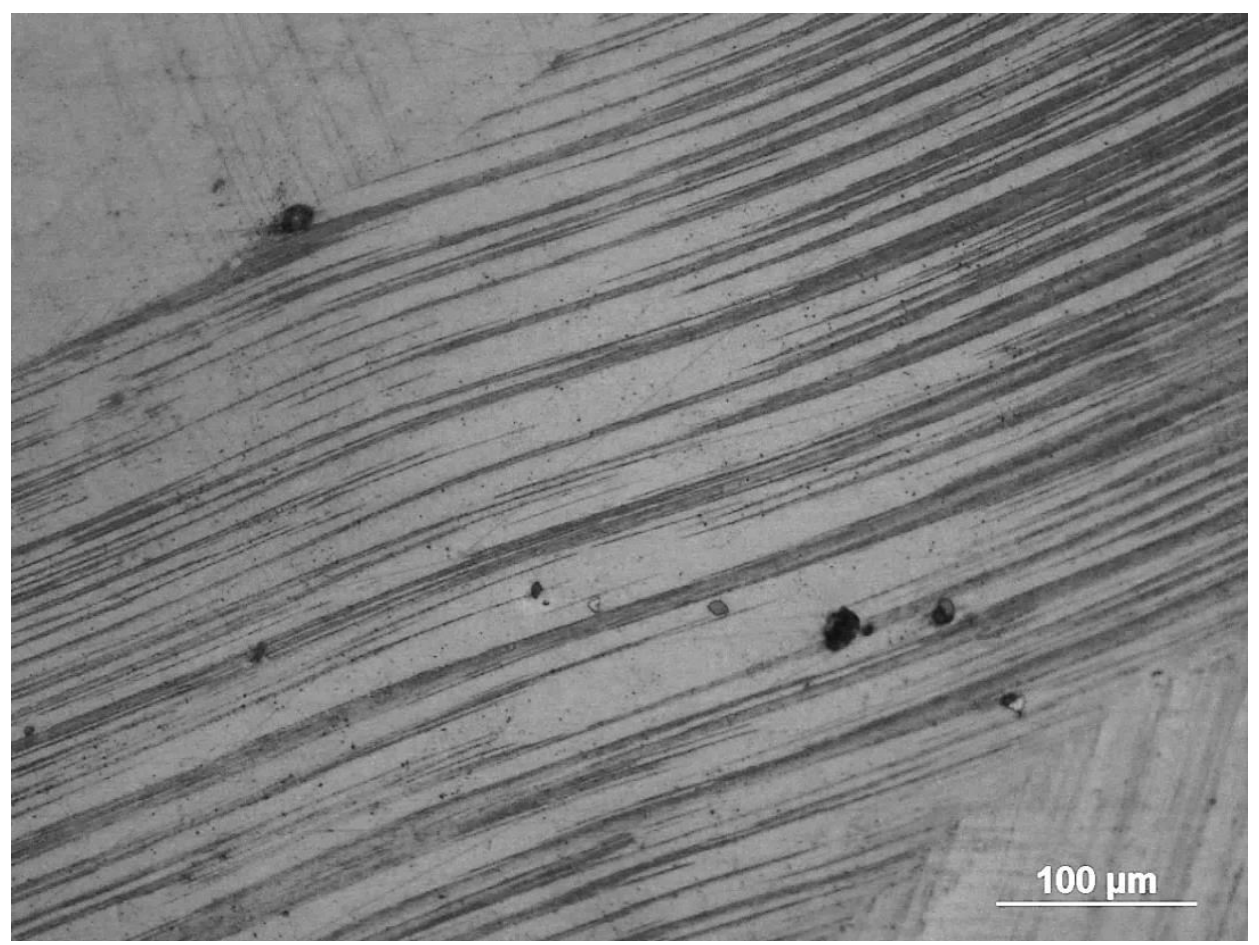


Figura 73 - Micrografia do corpo de prova de aço Hadfield refinado com $0,1 \% \mathrm{Hf}$ rompido no ensaio de impacto. (a) Região próxima ao entalhe. Aumento original de 50x; (b) Detalhe dos grãos austeníticos. Ataque Nital 5\%. Aumento original de 500x. Microscópio óptico.

(a)

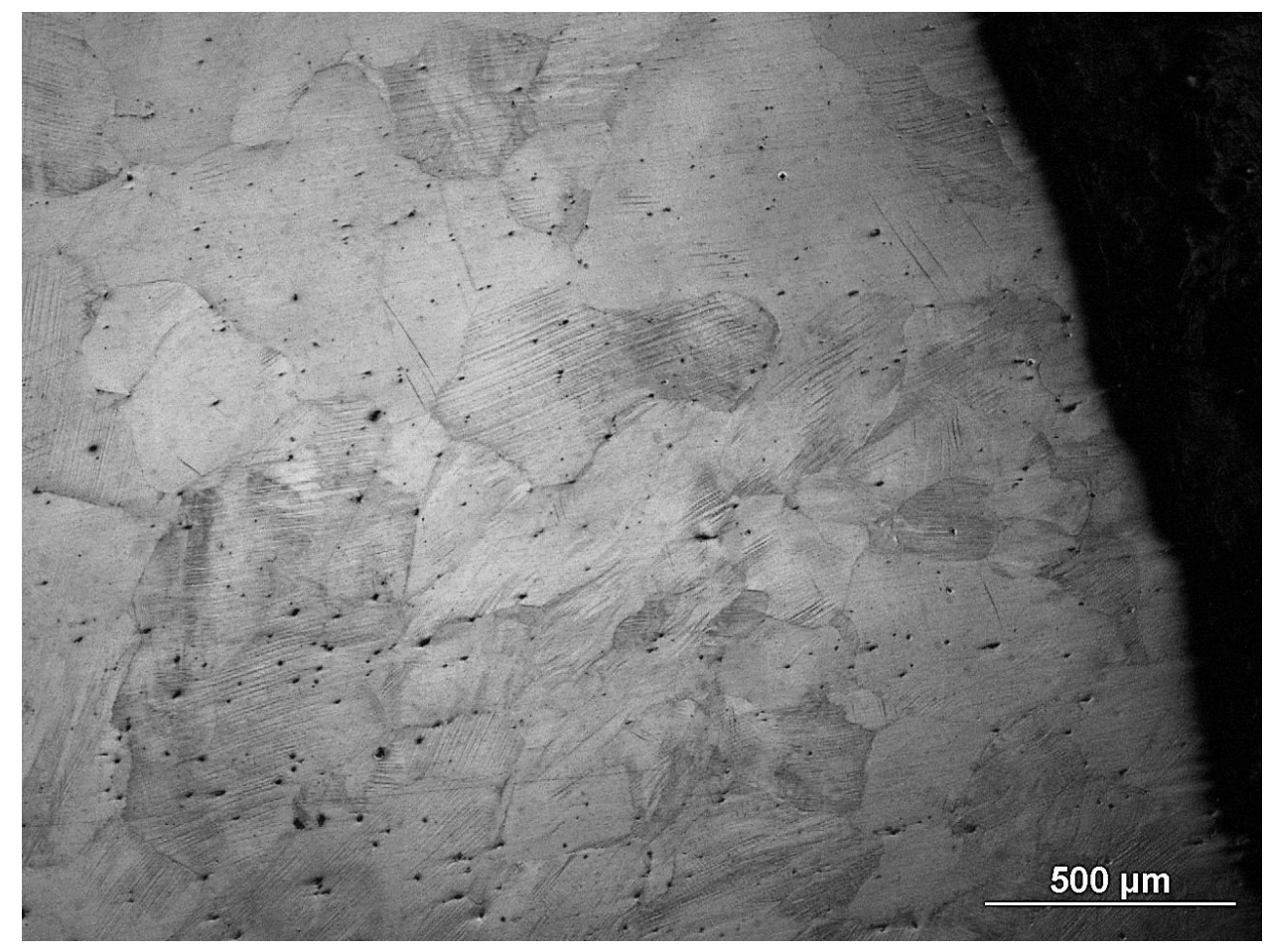

(b)

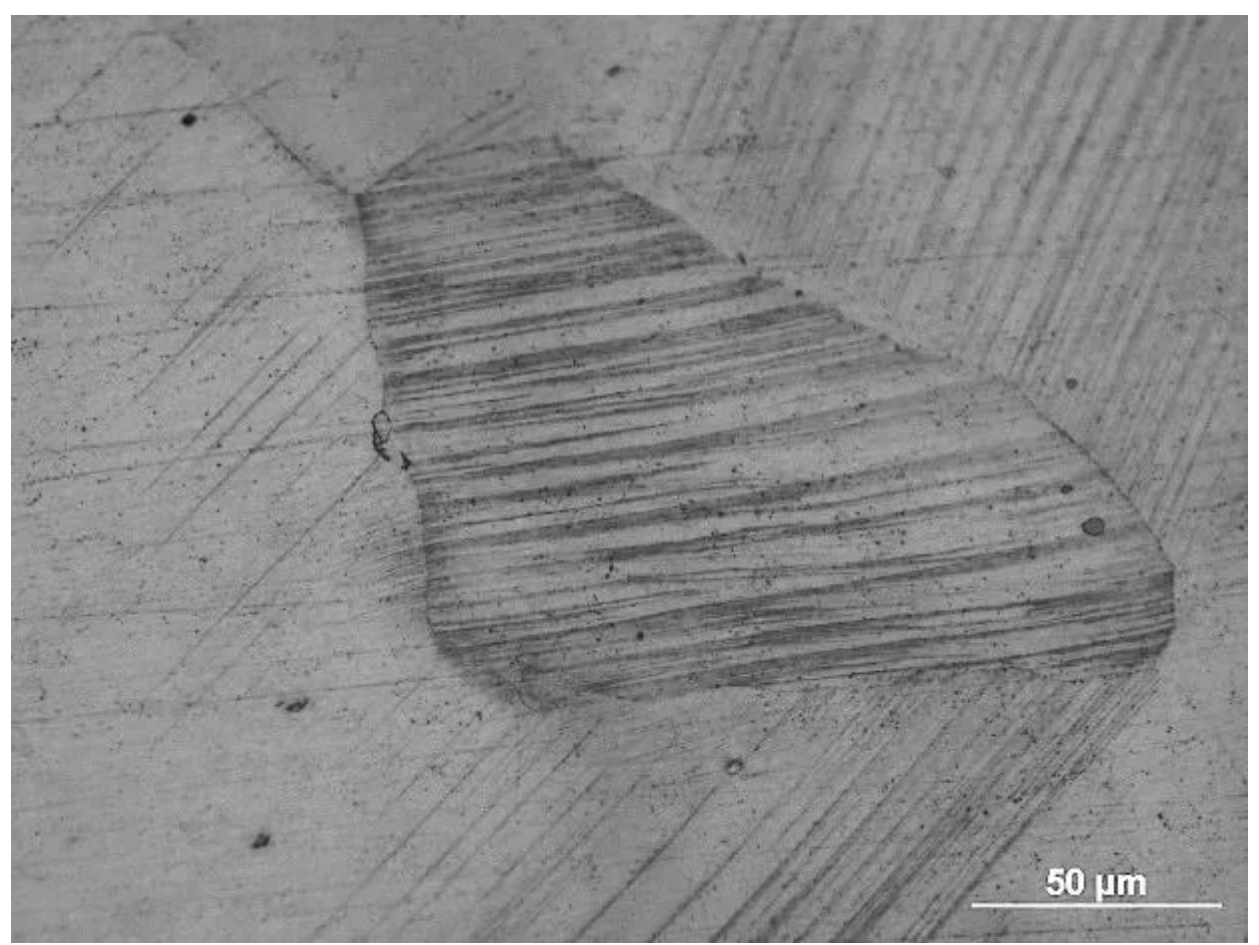


Tabela 17 - Densidade de maclas e do espaçamento entre as maclas para o aço Hadfield sem refino.

\begin{tabular}{|c|c|c|}
\hline Medidas & $\begin{array}{c}\text { Densidade de maclas } \\
\text { (maclas por } \mu \mathrm{m}, \\
\text { aumento } 100 \mathrm{x})\end{array}$ & $\begin{array}{c}\text { Espaçamento entre as } \\
\text { maclas }(\mu \mathrm{m})\end{array}$ \\
\hline 1 & $24 \pm 4$ & $20 \pm 6$ \\
\hline 2 & $26 \pm 4$ & $16 \pm 6$ \\
\hline 3 & $31 \pm 4$ & $13 \pm 6$ \\
\hline 4 & $21 \pm 4$ & $16 \pm 6$ \\
\hline 5 & $18 \pm 4$ & $21 \pm 6$ \\
\hline Média: & 24 & 17 \\
\hline
\end{tabular}

Tabela 18 - Densidade de maclas e do espaçamento entre as maclas para o aço Hadfield refinado

\begin{tabular}{|c|c|c|}
\hline Medidas & $\begin{array}{c}\text { Densidade de maclas } \\
(\text { maclas por } \mu \mathrm{m})\end{array}$ & $\begin{array}{c}\text { Espaçamento entre as } \\
\text { maclas }(\mu \mathrm{m})\end{array}$ \\
\hline 1 & $44 \pm 6$ & $7 \pm 4$ \\
\hline 2 & $46 \pm 6$ & $9 \pm 4$ \\
\hline 3 & $35 \pm 6$ & $15 \pm 4$ \\
\hline 4 & $51 \pm 6$ & $8 \pm 4$ \\
\hline 5 & $32 \pm 6$ & $17 \pm 4$ \\
\hline Média: & 42 & 11 \\
\hline
\end{tabular}




\section{DISCUSSÃO}

Os resultados das simulações realizadas no software Thermo-Calc mostraram para a composição química do aço Hadfield estudado (13\% de $\mathrm{Mn}$, $0,65 \%$ de $\mathrm{Si}$ e $1,2 \%$ de $\mathrm{C}$ ) que o $\mathrm{C}$ é o elemento que mais particiona para o estado liquido durante a solidificação, seguido pelo $\mathrm{Mn}$, enquanto que o $\mathrm{Si}$ possui partição inversa (figura 44). Na simulação da sequência de solidificação no equilíbrio do aço Hadfield com a adição de $0,1 \% \mathrm{Hf}$ foi observado que a temperatura de formação da austenita $\left(1378^{\circ} \mathrm{C}\right)$ ocorre abaixo da temperatura de formação de um precipitado sólido rico em $\mathrm{Hf}\left(1472^{\circ} \mathrm{C}\right)$.

Bramfitt (BRAMFITT, 1969) mostrou que a capacidade de uma inclusão em se tornar um sítio de nucleação heterogênea (inoculante) está baseada no desajuste cristalográfico, um valor que indica a diferença cristalográfica entre o inoculante e a fase matriz (BRAMFITT, 1969), que introduz o valor do termo de energia da interface inoculante/núcleo no balanço energético da nucleação durante a solidificação, favorecendo a nucleação heterogênea pela redução da barreira energética para a nucleação (PORTER ET AL, 2009). O precipitado rico em $\mathrm{Hf}$ foi identificado como tendo estrutura cristalina do tipo CFC, assim como a fase austenita, sugerindo que este composto seria um inoculante ideal em termos de estrutura cristalina. Não existem comentários específicos na literatura explicando o efeito inoculante do $\mathrm{Hf}$ no refino do grão austenítico de aços Hadfield, mas para ligas de Mg, existem evidências da atuação de sítios de nucleação heterogênea no refino microestrutural de solidificação (WANG, 2010). A caracterização microestrutural mostrou que o aço Hadfield refinado possui tamanho de grão equiaxial médio $(600 \mu \mathrm{m})$ aproximadamente cinco vezes menor do que a zona equiaxial do aço Hadfield sem refino (3000 $\mu \mathrm{m})$, ou seja, a adição de $\mathrm{Hf}$ no jato do forno para a panela (durante a fundição) promoveu o refino do tamanho de grão austenítico (figuras 47 a 50 , e 52 a 54). Além disso, foram encontradas partículas de $\mathrm{Hf}$ (com diâmetro em torno de 1 $\mu \mathrm{m})$ nas fractografias das amostras do aço Hadfield refinado rompidas no ensaio de impacto (figura 72). Sugere-se, deste modo, que a adição de $\mathrm{Hf}$ metálico no jato do forno para a panela (durante a fundição) promoveu a nucleação heterogênea e o refino microestrutural da fase austenita durante a solidificação do aço Hadfield, provavelmente pela formação de partículas 
sólidas ricas em Hf antes da solidificação. Recomenda-se que novos trabalhos investiguem os mecanismos de atuação do $\mathrm{Hf}$ como inoculante na solidificação de aços Hadfield, de modo a se obter microestruturas austeníticas com grãos mais refinadas (da ordem de $10 \mu \mathrm{m}$ ).

A caracterização microestrutural do aço Hadfield após o tratamento térmico de solubilização realizado à temperatura de $1120^{\circ} \mathrm{C}$ por 10 horas, mostrou que o tempo e a temperatura utilizados para o tratamento térmico foram eficazes na dissolução dos carbonetos interdendríticos e das colônias de perlita presentes na microestrutura bruta de fundição (figuras 49 e 50). Recomenda-se a realização de estudos mais detalhados, efetuando cálculos de difusão para homogeneização, testando novos ciclos de tratamento térmico e verificando os perfis de segregação, de modo a determinar com precisão o grau de homogeneização que pode ser obtido pelo tratamento de solubilização.

O estudo da fração de microporosidades presentes nas amostras extraídas do bloco e do "keel block", após o tratamento térmico de solubilização, mostrou que o bloco não é o tipo de amostra adequada para a extração de corpos de prova para ensaios mecânicos. Como foi observado, os valores da fração pontual e em área são elevados para as amostras extraídas do bloco (vide tabela 14, e figuras 66 e 67), e comprometeram os resultados obtidos no ensaio de impacto Charpy, principalmente para o aço Hadfield refinado (vide tabelas 15 e 16). As microporosidades atuam como concentradores de tensão e facilitam a propagação das trincas, como foi observado no exame fractográfico das amostras rompidas no ensaio de impacto (figura 73). Dessa forma, os corpos de prova extraídos do "keel block" apresentaram baixa fração pontual e em área de microporosidades (vide a tabela 14, e as figuras 66 e 67), e assim os resultados do ensaio de impacto e tração dessas amostras não foram influenciados pela presença de microporosidades.

Os resultados do ensaio de tração dos corpos-de-prova extraídos do "keel block" mostraram ligeiro aumento nos valores médios do limite de escoamento (6\%), do módulo de Young (5\%) e da resiliência (8\%) com a diminuição do tamanho de grão austenítico de tamanho de grão de $3000 \mu \mathrm{m}$ para $600 \mu \mathrm{m}$. As outras propriedades mecânicas, por outro lado, mostraram 
aumento significativo de valores com a redução do tamanho de grão de 3000 $\mu \mathrm{m}$ para $600 \mu \mathrm{m}$ : resistência à tração $(37 \%)$, coeficiente de encruamento $(30 \%)$, alongamento $(53 \%)$ e tenacidade $(88 \%)$.

Astaf'ev (ASTAF'EV, 1997) estudou a influência do tamanho de grão na resistência a fratura, no alongamento e na resistência à abrasão sob impacto de aços ao manganês austeníticos com composição química de $1,28 \%$ de $C$, $12,2 \%$ de $\mathrm{Mn}$ e $0,77 \%$ de $\mathrm{Si}$. Os resultados obtidos por Astaf'ev (1997) mostraram que a resistência a fratura aumentou de 400 para $1000 \mathrm{MPa}$, e o alongamento aumentou de 10 para $45 \%$, com a redução do tamanho de grão de $254 \mu \mathrm{m}$ para 63,5 $\mu \mathrm{m}$ (ASTAF'EV, 1997). O valor da resistência à abrasão sob impacto aumentou (de 2,4 para $3,2 \mathrm{~kg} \cdot \mathrm{cm}^{2} / \mathrm{g}$ ) com a redução do tamanho de grão (de $254 \mu \mathrm{m}$ para 63,5 $\mu \mathrm{m}$ ) (ASTAF'EV, 1997). No entanto, a faixa de tamanho de grão (63,5 a $254 \mu \mathrm{m}$ ) estudada por Astaf'ev (1997) é menor do que o tamanho de grão do aço Hadfield sem refino $(3000 \mu \mathrm{m})$ e refinado $(600 \mu \mathrm{m})$ estudados no presente trabalho. Além disso, os valores do alongamento para 0 aço austenítico obtido por (ASTAF'EV, 1997) são menores do que o alongamento do aço Hadfield sem refino (valor médio de $46,5 \%$ ) e do refinado (valor médio de $71 \%$ ).

Karaman (KARAMAN, 2000) estudou a curva de tensão de tração versus deformação do aço Hadfield laminado (12,3\% de Mn e 1,03\% de C) após tratamento térmico de solubilização $\left(1100^{\circ} \mathrm{C}\right.$ por $\left.1 \mathrm{~h}\right)$ com tamanhos de grão austeníticos de 100, 300 e $1000 \mu \mathrm{m}$ para verificar o efeito do tamanho de grão sobre as propriedades mecânicas. A comparação dos resultados de tração obtidos no presente estudo com os de Karaman (KARAMAN, 2000) indica que as curvas de tensão versus deformação obtidas no presente trabalho são compatíveis com a literatura, vide figura 74 . No entanto, os valores de alongamento e de resistência à tração obtidos para os aços Hadfield no presente estudo (em torno de $580 \mathrm{MPa}$ para o aço Hadfield com $1000 \mu \mathrm{m}$ e em torno de $660 \mathrm{MPa}$ para o aço Hadfield com tamanho de $300 \mu \mathrm{m}$ ) são significativamente maiores do que os valores obtidos por Karaman (KARAMAN, 2000), vide figura 75 . 
Figura 74 - Curvas de tensão (MPa) versus deformação do aço Hadfield com tamanhos de grão de 100, 300 e $1000 \mu$ m.

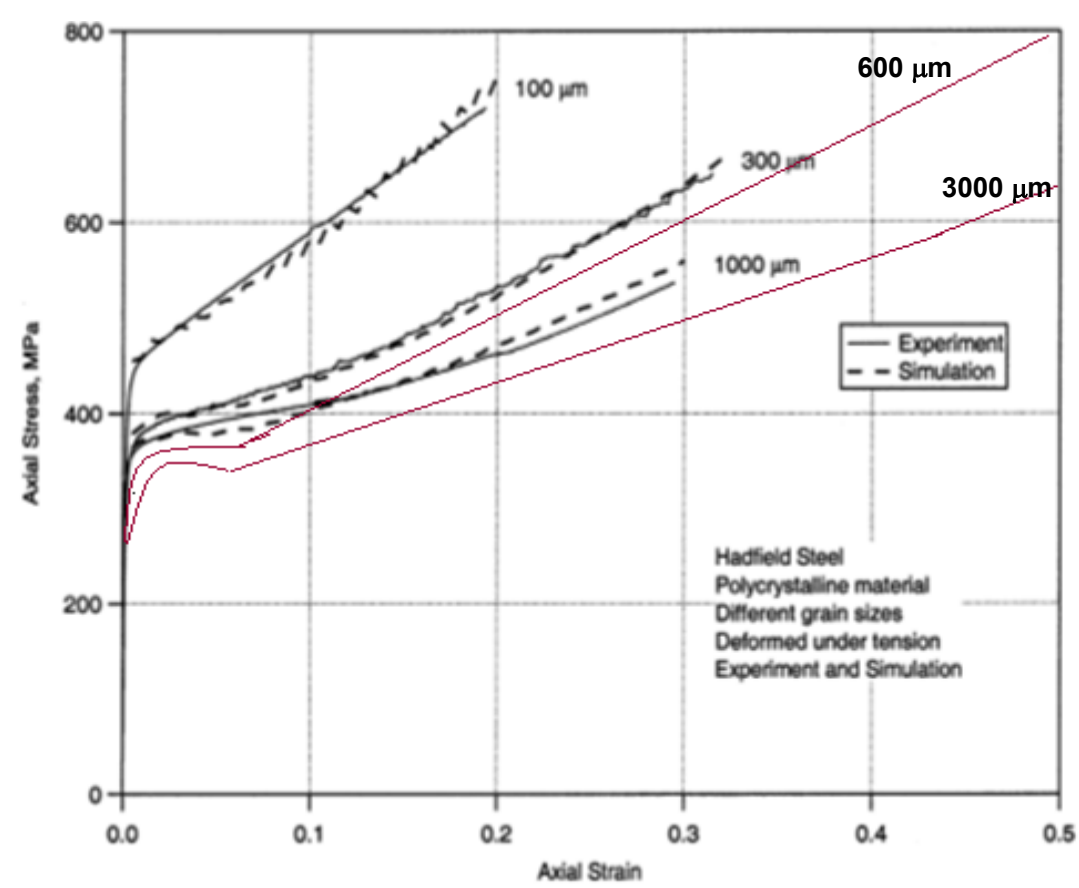

Fonte: Modificado de Karaman, 2000.

As constantes da equação de Hall-Petch ( $\sigma_{\circ}$ e $k_{H P}$, vide equação 1$)$ foram extrapoladas a partir dos valores médios do tamanho de grão austenítico (d) e do limite de escoamento $\left(\sigma_{Y}\right)$ do aço Hadfield tanto para a condição sem refino $(d=3 \mathrm{~mm})$ quanto para a condição refinada $(d=0,6 \mathrm{~mm})$. $O$ valor extrapolado para a tensão teórica do limite de escoamento do monocristal $\left(\sigma_{\circ}\right)$ foi de $318 \mathrm{MPa}$ e o valor da constante de Hall-Petch $\left(\mathrm{k}_{\mathrm{HP}}\right)$ foi de $0,89 \mathrm{MPa} \cdot \mathrm{m}^{-1 / 2}$. O valor encontrado para a constante de Hall-Petch $\left(\mathrm{k}_{\mathrm{HP}}=0,89 \mathrm{MPa} \cdot \mathrm{m}^{-1 / 2}\right)$ e para a tensão teórica do limite de escoamento de um monocristal (318 MPa) são elevados em comparação com o estudo de Kako (KAKO et al, 2002) em aços austeníticos, como mostrado na tabela 19. Kako et al (KAKO et al, 2002) estudaram o efeito da adição de elementos de liga ( $\mathrm{Si}, \mathrm{Mn}, \mathrm{P}, \mathrm{S}, \mathrm{C}$ e N) nas propriedades de tração de uma liga austenítica de elevada pureza $\mathrm{Fe}-\mathrm{Cr}-\mathrm{Ni}$ com composição química de $18 \%$ de $\mathrm{Cr}, 14 \%$ de $\mathrm{Ni}, 14 \%$ de $\mathrm{Mn}$ e $0,5 \%$ de Si laminado e após tratamento térmico de homogeneização $\left(1220^{\circ} \mathrm{C}\right.$ por $\left.2 \mathrm{~h}\right)$. $\mathrm{O}$ valor da tensão teórica do limite de escoamento de um monocristal e da constante de Hall-Petch são $420 \%$ e $85 \%$ respectivamente mais altos do que o valor encontrado por KAKO (KAKO et al, 2002). No entanto, a extrapolação no 
presente estudo utilizando a equação de Hall-Petch foi realizada para apenas dois pontos (dois tamanhos de grãos: $3000 \mu \mathrm{m}$ e $600 \mu \mathrm{m}$ ), sendo necessário estudos posteriores para a obtenção de amostras de aço Hadfield com diferentes tamanhos de grão para diminuir o erro experimental associado com o limite de escoamento e as medidas do tamanho de grão que são parâmetros utilizados na determinação da constante de Hall-Petch $\left(\mathrm{k}_{\mathrm{HP}}\right)$ e da tensão teórica do limite de escoamento de um monocristal $\left(\sigma_{\circ}\right)$.

$$
\sigma_{e}=\sigma_{o}+K_{H P .} d^{\frac{-1}{2}}(1)
$$

Sendo: $\sigma_{e}=$ tensão de escoamento $(\mathrm{MPa}), \sigma_{o}=$ tensão teórica para o limite de escoamento de um monocristal, $K_{H P}=$ constante de Hall-Petch e d $=$ tamanho de grão.

Tabela 19 - Comparação entre os parâmetros da equação de Hall-Petch para o aço Hadfield e o aço austenítico (composição química de $18 \%$ de $\mathrm{Cr}, 14 \%$ de Ni, $4 \%$ de $\mathrm{Mn}$ e $0,5 \%$ de Si) da literatura.

\begin{tabular}{|c|c|c|c|c|}
\hline Amostra & $\begin{array}{l}\text { Tamanho } \\
\text { de grão } \\
\text { médio, } \\
\text { (mm) }\end{array}$ & $\begin{array}{l}\text { Limite de } \\
\text { escoamento } \\
\text { médio } \\
(\mathrm{MPa})\end{array}$ & $\begin{array}{l}\text { Constante de Hall- } \\
\text { Petch }\left(\mathrm{K}_{\mathrm{HP}}, \mathrm{MPa} \cdot \mathrm{m}^{-1 / 2}\right)\end{array}$ & $\begin{array}{c}\text { Tensão teórica } \\
\text { para o limite de } \\
\text { escoamento de } \\
\text { um monocristal } \\
\left(\sigma_{\mathrm{o}} \mathrm{MPa}\right)\end{array}$ \\
\hline $\begin{array}{c}\text { Aço Hadfield sem } \\
\text { refino }\end{array}$ & $3 \pm 1$ & $334 \pm 11$ & \multirow{2}{*}{0,89} & \multirow[b]{2}{*}{318} \\
\hline $\begin{array}{c}\text { Aço Hadfield } \\
\text { refinado }\end{array}$ & $0,6 \pm 0,3$ & $355 \pm 11$ & & \\
\hline $\begin{array}{c}\text { *Aço austenítico com } \\
\text { composição química } \\
\text { de } 18 \% \mathrm{Cr}, 14 \% \mathrm{Ni} \text {, } \\
4 \% \mathrm{Mn} \text { e } 0,5 \% \mathrm{Si}\end{array}$ & ${ }^{*} 0,08$ & *79 & ${ }^{*} 0,452$ & *75 MPa \\
\hline
\end{tabular}

${ }^{*}$ Fonte: KAKO et al, 2002. 
Assim, o atual refino de grão austenítico (redução do tamanho de grão em 5 vezes) não foi um mecanismo eficaz para o aumento significativo do limite de escoamento do aço Hadfield. Para que seja obtido um aumento significativo do limite de escoamento em 40\% deste aço (de 334 para $467 \mathrm{MPa}$ ) seria necessário a obtenção de um tamanho de grão austenítico de $10 \mu \mathrm{m}$. No entanto, o limite de escoamento não é única propriedade de interesse para a melhoria da vida de componentes do aço Hadfield usados nas indústrias de mineração e ferroviária. Nestas aplicações, o aço Hadfield é utilizado em regime plástico e o interesse tecnológico está no aumento da tenacidade desta classe de materiais. Aliás, a lei de Hall-Petch não explica o aumento nos valores de resistência à tração $(37 \%)$, coeficiente de encruamento $(30 \%)$, alongamento $(53 \%)$ e tenacidade $(88 \%)$ obtidos com a redução do tamanho de grão austenítico do aço Hadfield de $3000 \mu \mathrm{m}$ para $600 \mu \mathrm{m}$. Estes resultados sugerem que o refino do grão está alterando o mecanismo dominante de deformação plástica do aço Hadfield: de escorregamento de discordâncias para maclação (ALLAIN ET AL, 2004; COOMAN ET AL, 2011; TSAKIRIS; EDMONDS, 1999).

O aumento observado no presente estudo nos valores de resistência à tração, do coeficiente de encruamento, do alongamento, da tenacidade e da energia absorvida com a redução do tamanho de grão austenítico (vide tabelas 9,10 e 11) não é previsto pelos mecanismos envolvidos na Lei de Hall-Petch, que está limitada ao valor do limite de escoamento dos materiais metálicos. Deste modo, os resultados sugerem que o refino do tamanho de grão austenítico causou uma mudança no mecanismo de deformação plástica do aço Hadfield.

Nos exames metalográficos e microfractográficos das amostras rompidas no ensaio de tração e impacto observou-se que o principal mecanismo de deformação no aço Hadfield refinado foi por maclação mecânica (vide figuras 63, 64, 74 e 75, e as tabelas 12, 13, 15 e 16). Na literatura, não existem estudos em relação ao efeito do tamanho de grão na deformação por maclação em aços austeníticos. Na literatura (ADLER ET AL, 1986; GRÄSSEL; FROMMEYER, 1998, QIN; BADESHIA, 2007) não existe um consenso em relação ao efeito da deformação por maclação nas propriedades de ductilidade, 
resistência à tração e taxa de encruamento do aço Hadfield, sendo que diferentes mecanismos tem sido propostos.

Os mecanismos de deformação plástica por escorregamento e maclação são competitivos. Em materiais CFC, o escorregamento seria o primeiro mecanismo de deformação plástica a ser ativado e então o núcleo da macla seria formado pela alta concentração de tensão que existe na frente do empilhamento de discordâncias em metais que possuem baixos valores da energia de falha de empilhamento, e que as discordâncias não fazem o desvio cruzado com facilidade, visto que o valor da tensão crítica para o escorregamento aumenta, fazendo com que a deformação plástica por maclação seja ativada (ABBASCHIAN, REED-HILL, 1964; SMALLMAM E BISHOP, 2014).

Tsakiris e Edmonds (TSAKIRIS; EDMONDS, 1999) e Cooman et al (COOMAN ET AL, 2011) propõem que para os aços TWIP (Twinning-induced plasticity stee/s), que possuem baixa energia de falha de empilhamento (20-30 $\mathrm{mJ} / \mathrm{m}^{2}$; ALLAIN ET AL, 2004) e baixa tensão critica para a maclação, em que a maclação é o primeiro mecanismo a ser ativado durante a deformação plástica destes aços. Nesse caso, os contornos das maclas subdividem os grãos da austenita e atuam como barreiras à propagação das discordâncias (vide figura 75), sugerindo que o aumento da resistência à tração e do coeficiente de encruamento com a redução do tamanho de grão está relacionado com o aumento da quantidade de maclas de deformação durante a deformação plástica de aços austeníticos (TSAKIRIS; EDMONDS, 1999; COOMAN et al, 2011). A energia de falha de empilhamento do aço Hadfield depende do teor de C e Mn presente na sua composição química, conforme figura 77 , sendo que $o$ aço Hadfield do presente estudo ( $12 \%$ de $\mathrm{Mn}$ e $1,2 \% \mathrm{C}$ ) possui EFE em torno de 30 a $40 \mathrm{~mJ} / \mathrm{m}^{2}$ (SCHUMANN, 1972). O aço Hadfield do presente trabalho apresentou aumento da taxa de encruamento e da resistência a tração com a redução do tamanho de grão, além de possuir valor médio da EFE, (30-40 $\mathrm{mJ} / \mathrm{m}^{2}$, conforme a figura 76 ), indicando uma maior atuação do mecanismo de maclação devido ao refino do tamanho de grão. Sugere-se ainda que o primeiro mecanismo a ser ativado durante a deformação plástica do aço Hadfield seja o de escorregamento, seguido pela maclação. 
Figura 75 - Figura esquemática mostrando os contornos das maclas de deformação subdividindo os grãos da austenita e reduzindo o caminho livre médio para o movimento das discordâncias.

Fonte de discordâncias

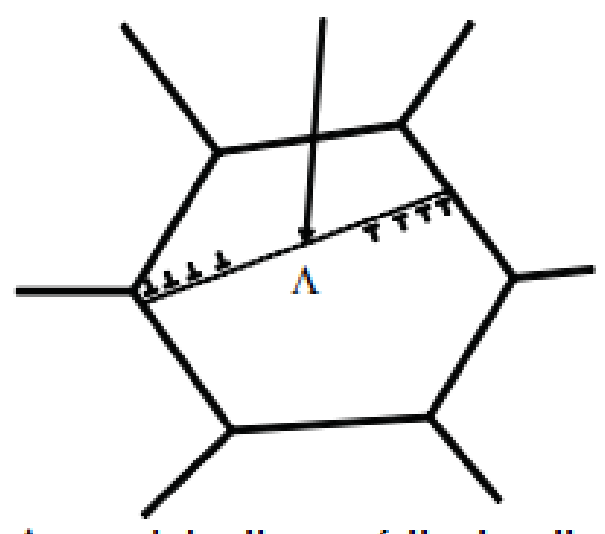

Maclas de deformação

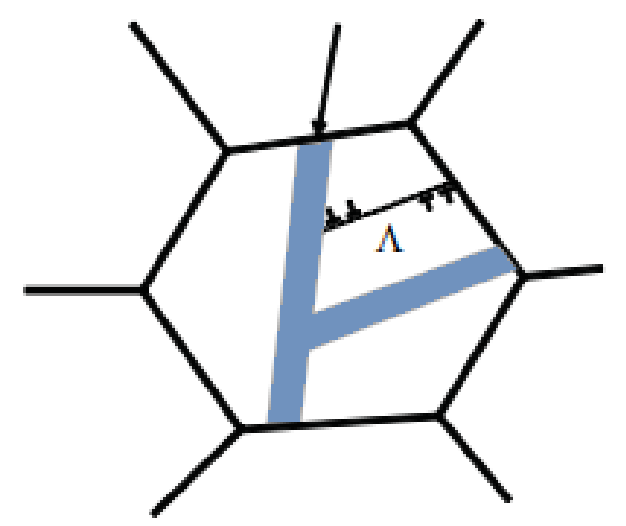

\section{$\Lambda$ : caminho livre médio das discordâncias}

Fonte: Modificado de Cooman et al, 2011.

Figura 76 - Mapa da energia de falha de empilhamento (EFE) em função do teor de $\mathrm{Mn}$ e $\mathrm{C}$ presentes na composição química à temperatura de $27^{\circ} \mathrm{C}$.
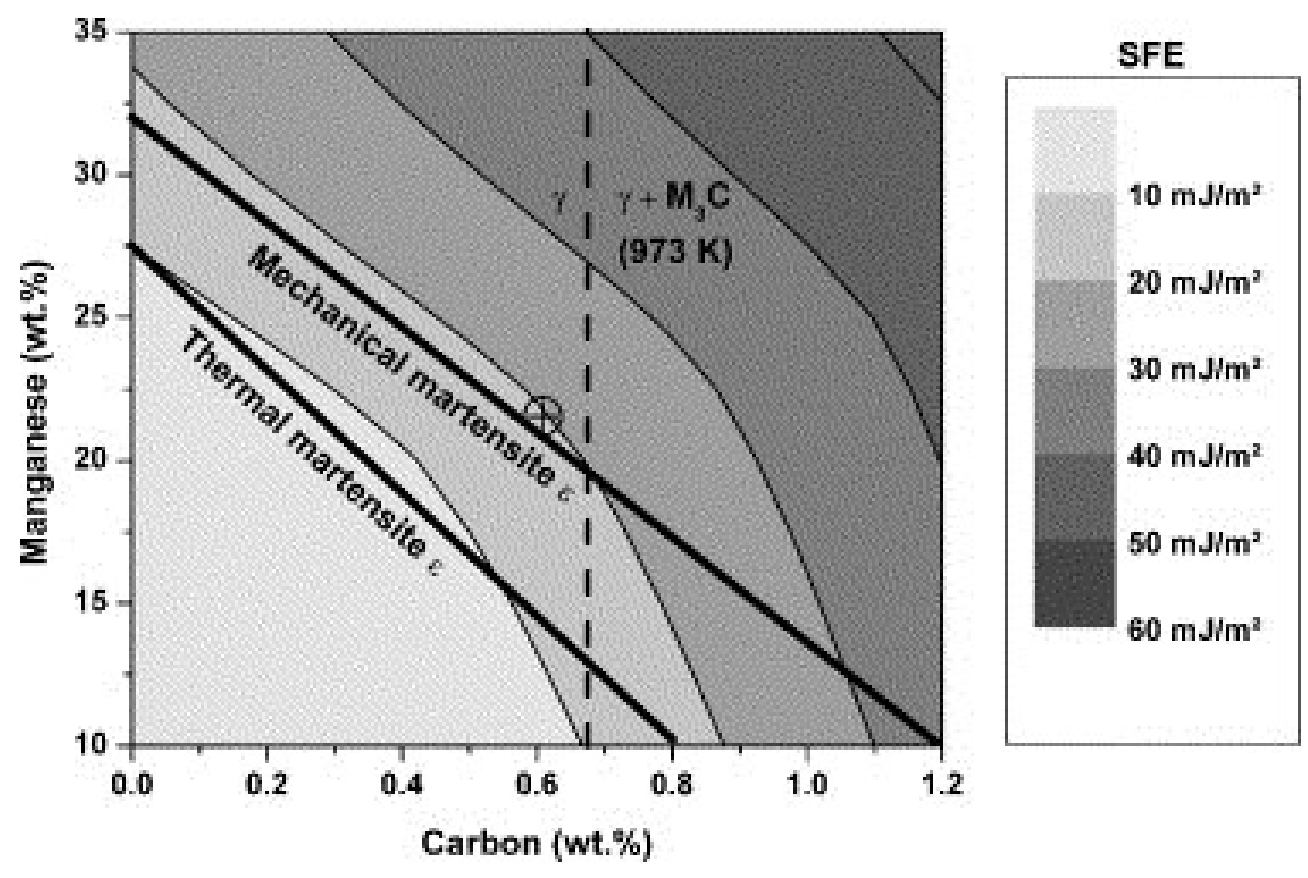

Fonte: Schumann, 1972. 
Adler et al (ADLER ET AL, 1986) estudaram as curvas de tensão versus deformação do aço Hadfield ( $13 \%$ de Mn e 1,2\% de C) com tamanho de grão austenítico médio igual a $220 \mu \mathrm{m}$ através de ensaios de tração e de compressão com taxa de deformação inicial de $8,3 \cdot 10^{-4} \cdot \mathrm{s}^{-1}$ e $6,7 \cdot 10^{-4} \cdot \mathrm{s}^{-1}$, respectivamente; e usando caracterização microestrutural por microscopia óptica. O tamanho de grão médio do aço Hadfield estudado por Adler (ADLER ET AL, 1986) é compatível com o tamanho de grão médio do aço Hadfield refinado do presente trabalho. Os resultados da caracterização microestrutural dos autores mostraram um aumento da quantidade de maclas de deformação (observação qualitativa, vide figura 77) com o aumento da deformação plástica durante os ensaios de tração e compressão. Os autores propuseram um mecanismo para explicar os resultados de elevada taxa de encruamento (em tração e em compressão) dos aços Hadfield. Segundo os autores, os átomos de carbono nos sítios octaédricos da estrutura CFC são trocados para sítios tetraédricos nas regiões macladas, o que introduz um aumento da dureza, responsável pela alta taxa de encruamento do aço Hadfield.

Figura 77 - Micrografia do aço Hadfield após o ensaio de tração à $20^{\circ} \mathrm{C}$ para a deformação de (a) 0,06, (b) 0,18 e (c) 0,30. Observa-se a presença de maclas de deformação que aumentam com o aumento da deformação.

(a)

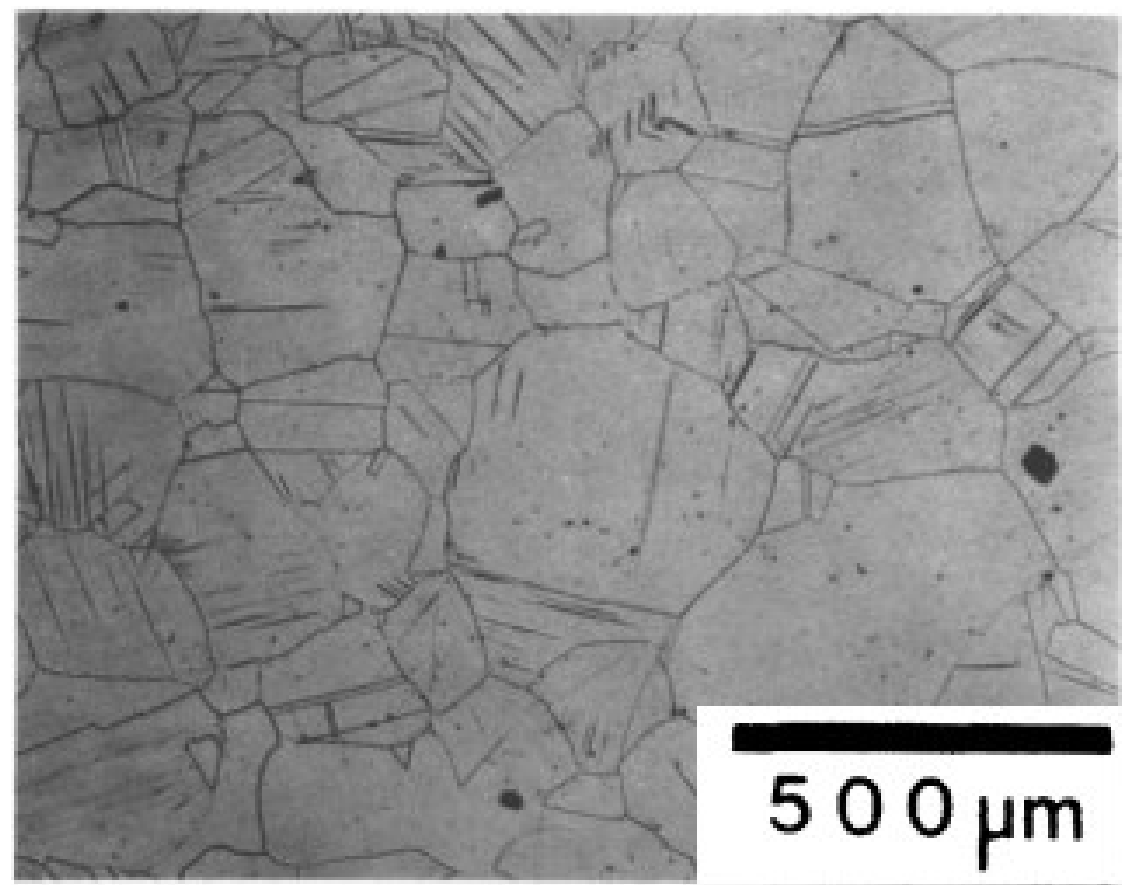


(b)

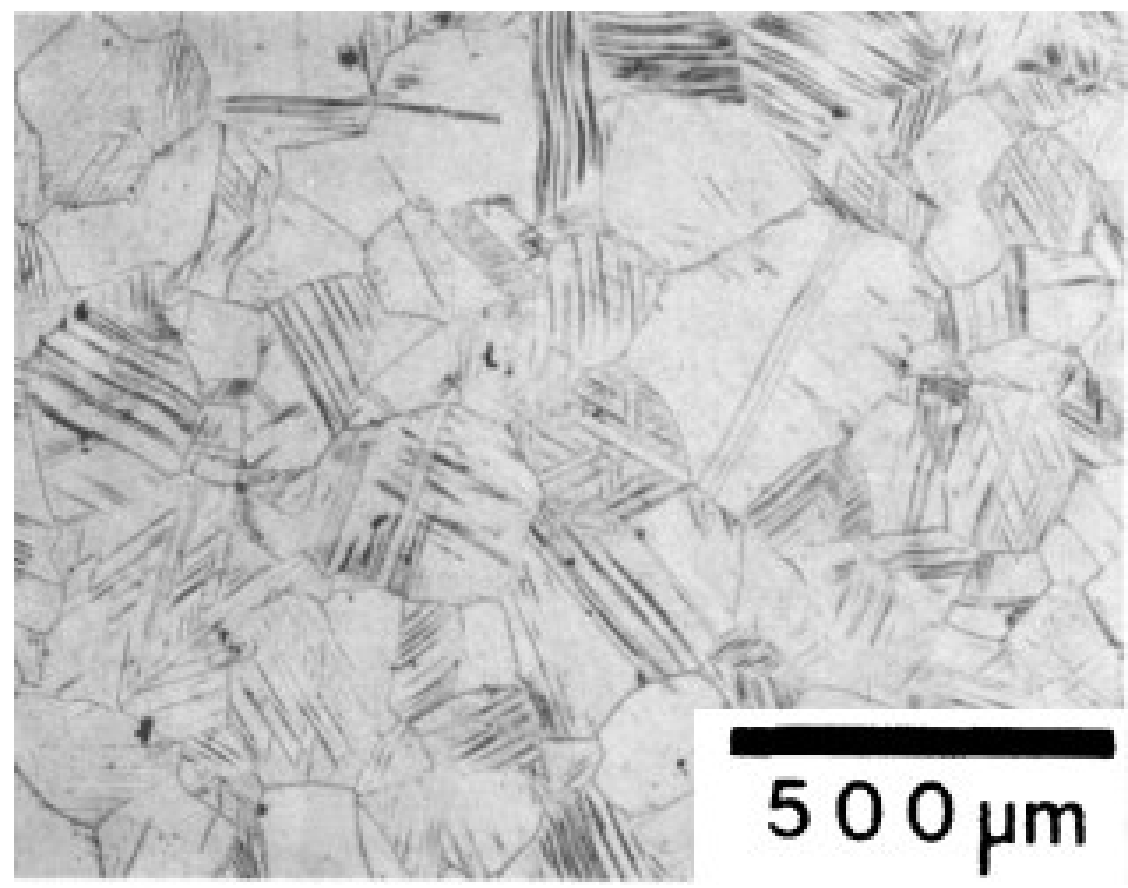

(c)

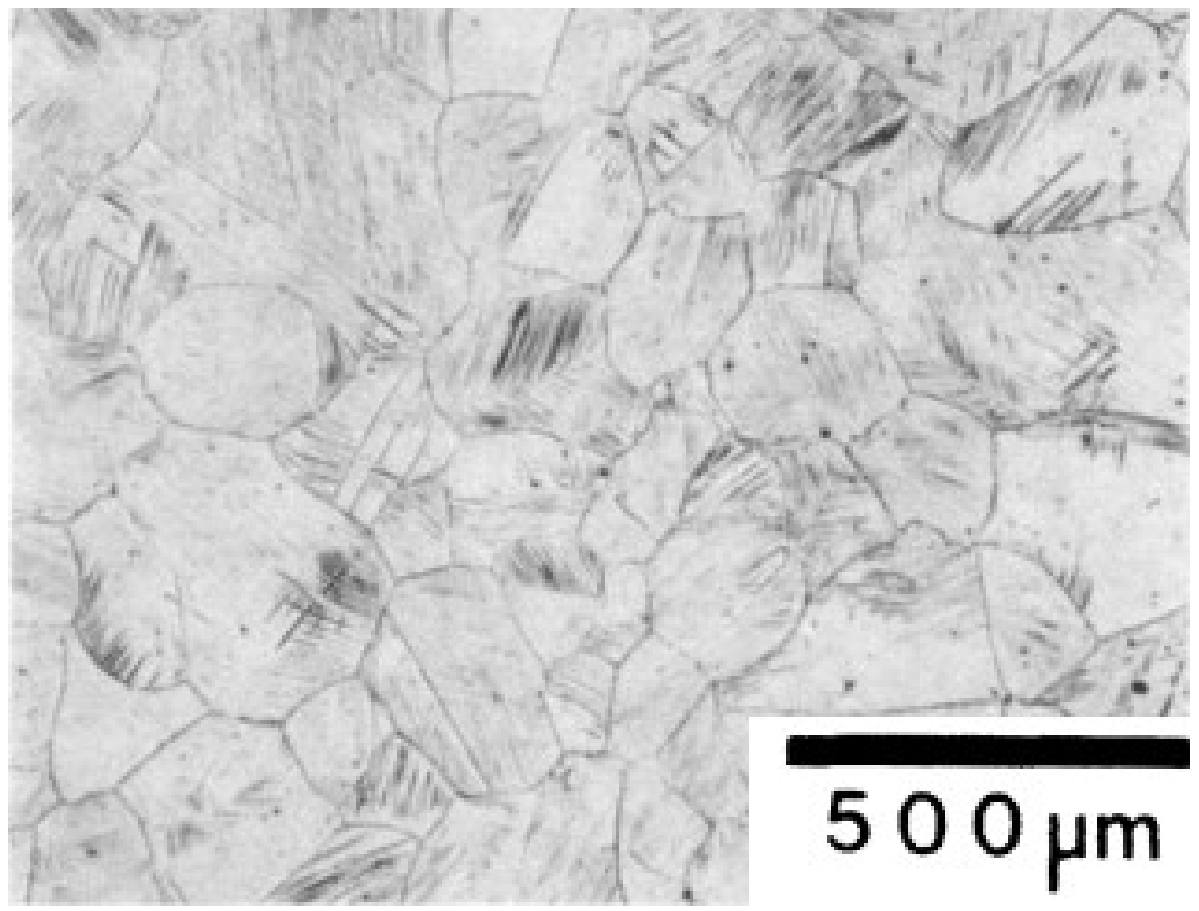


Qin e Badeshia (QIN; BADESHIA, 2007) estudaram o efeito da maclação na deformação plástica de um aço TWIP (25\% Mn, 3\% Si e $3 \%$ de Al), que apresenta elevado alongamento (60 - 95\%). Segundo os autores, a deformação plástica por maclação é um mecanismo importante para a deformação plástica dos aços TWIP, porém não contribui de forma significativa para o alongamento total. $O$ presente trabalho, no entanto, mostrou um aumento de $46 \%$ no número de maclas por $\mu \mathrm{m}$ (19 \pm 4 maclas por $\mu \mathrm{m}$ para $\circ$ aço Hadfield sem refino e $35 \pm 5$ maclas por $\mu \mathrm{m}$ para o aço Hadfield refinado) e este aumento resultou no aumento do valor do alongamento (de $46 \pm 5$ na condição sem refino para $71 \pm 5$ na condição refinada) da condição refinada em comparação com a condição sem refino. Dessa forma, o aumento da proporção de deformação plástica por maclação causada pelo refino do grão austenítico promoveu uma maior ductilidade do aço Hadfield refinado no presente estudo.

Gadheri et al (GADHERI et al, 2011) estudou o efeito do tamanho de grão na deformação por maclação em ligas de Ti (estrutura $\mathrm{HC}$ ) laminadas através de ensaios de tração e de caracterização microestrutural. O tamanho de grão médio das amostras de Ti analisadas estava na faixa de 18 a $200 \mu \mathrm{m}$ e os os autores observaram que ocorreu uma diminuição da densidade de maclas com a redução do tamanho de grão para o Ti. Os resultados do presente trabalho não estão em acordo com os resultados de Gadhrei et al, visto que a densidade de maclas aumentou em $46 \%$ (considerando-se os valores médios, vide tabelas 12 e 13) no ensaio de tração com a redução do tamanho de grão de $3000 \mu \mathrm{m}$ para $600 \mu \mathrm{m}$. No entanto, o Ti puro apresenta estrutura cristalina do tipo $\mathrm{HC}$, que por apresentar apenas 3 sistemas de escorregamento disponíveis na temperatura ambiente, favorece a deformação plástica por maclação.

Zhu et al (ZHU ET AL, 2013) estudaram o efeito do tamanho de grão na faixa de $2 \mu \mathrm{m}$ a $100 \mathrm{~nm}$ na deformação por maclação no Cu e Ni (estrutura cristalina (FC) através de uma revisão dos dados experimentais encontrados na literatura. Os autores mostraram que, para metais com estrutura cristalina do tipo CFC como o $\mathrm{Ni}$, a densidade de maclas presentes na microestrutura diminui com a redução do tamanho de grão. Os resultados do presente 
trabalho não estão em acordo com o observado por Zhu et al (ZHU ET AL, 2013), visto que densidade de maclas aumentou com a redução do tamanho de grão. No entanto, o tamanho de grão das amostras de aço Hadfield sem refino $(3000 \mu \mathrm{m})$ e refinado $(600 \mu \mathrm{m})$ são muito maiores do que a faixa de tamanho de grão estudada por Zhu et al (2 $\mu \mathrm{m}$ a $100 \mathrm{~nm})$. Além disso, Cu e o Ni apresentam elevada energia de falha de empilhamento (na faixa de 120-130 $\mathrm{mJ} / \mathrm{m}^{2}$; CARTER; HOLMES, 1977), de modo que a maclação só ocorre em condições de elevada taxa de deformação ou em baixas temperaturas. Assim, os mecanismos envolvidos deformação plástica por maclação em $\mathrm{Cu}$ e $\mathrm{Ni}$ provavelmente são diferentes do que ocorre para o aço Hadfield que possui energia de falha de empilhamento média na faixa de $30-40 \mathrm{~mJ} / \mathrm{m}^{2}$ (ALLAIN ET AL, 2004; SCHUMANN, 1972).

Jilin et al (JILIN ET AL, 2016) estudaram o efeito do tamanho de grão austenítico na dureza e no valor da energia absorvida no impacto Charpy em um aço de elevada resistência SCM435H laminado. Os resultados dos autores mostraram um aumento da energia absorvida no impacto de $60 \mathrm{~J} / \mathrm{cm}^{2}$ para 140 $\mathrm{J} / \mathrm{cm}^{2}$ com a redução do tamanho de grão de $40 \mu \mathrm{m}$ para $7 \mu \mathrm{m}$. Os resultados dos autores estão em acordo com os resultados do presente trabalho. Os resultados mostraram um aumento de $13 \%$ na energia absorvida ao impacto para o aço Hadfield refinado em comparação com o aço Hadfield sem refino. No entanto, a caracterização microestrutural das amostras do aço $\mathrm{SCM} 435 \mathrm{H}$ não apresentaram maclas de deformação. Além disso, a faixa de tamanho de grão estudada por Jilin et al (JILIN ET AL, 2016) é pequena em comparação com o aço Hadfield estudado. E por fim, a energia absorvida no impacto para o aço $\mathrm{SCM} 435 \mathrm{H}$ é baixa $\left(60-140 \mathrm{~J} / \mathrm{cm}^{2}\right)$ se comparada ao aço Hadfield estudado $\left(150-180 \mathrm{~J} / \mathrm{cm}^{2}\right)$. Não existem estudos na literatura mostrando a influencia do tamanho de grão na energia absorvida no impacto para materiais austeníticos com baixa ou média EFE e tamanho de grão compatíveis com o do aço Hadfield estudado.

Os resultados dos ensaios mecânicos e da caracterização microestrutural sugerem que o refino do tamanho de grão austenítico favorece a deformação plástica por maclação. Assim como no escorregamento, a 
maclação também depende da Lei de Schmid, ou seja, existe uma tensão crítica e uma orientação cristalográfica preferencial para que a maclação seja ativada em metais CFC, que apresentam sistema de maclação do tipo $<11$ $2>\{111\}$. $O$ aço Hadfield refinado apresenta uma maior quantidade de grãos com orientação aleatória, possivelmente existe uma maior quantidade de grãos com orientação favorável em relação aos sistemas de escorregamento/maclação preferenciais, de modo que a ativação da deformação por maclação seja facilitada.

Finalmente, os resultados do presente trabalho indicaram que o aumento da densidade de maclas mecânicas com a redução do tamanho de grão austenítico em aço Hadfield (vide tabelas 12, 13, 17 e 18) promoveu o aumento dos valores da ductilidade, tenacidade, coeficiente de encruamento e da energia absorvida no impacto (vide tabelas 9, 10, 11 e16). 


\section{CONCLUSÕES}

A caracterização macroestrutural mostrou que o aço Hadfield com adição de Hf apresenta menor tamanho do grão austenítico em comparação ao aço Hadfield sem refino, que foi confirmado pela técnica de EBSD.

As medidas do tamanho do grão austeníticos mostraram que o aço Hadfield refinado possui tamanho de grão equiaxial médio igual a $600 \mu \mathrm{m}$, que é aproximadamente cinco vezes menor do que o tamanho de grão médio da zona equiaxial do aço Hadfield sem refino $(3000 \mu \mathrm{m})$.

Os resultados da caracterização microestrutural dos corpos de prova extraídos do bloco e do "keel block" mostraram que a fração de microporosidades influencia na energia absorvida no impacto e deve ser mantida o mínimo possível para não comprometer os resultados obtidos no ensaio mecânico.

Os resultados do ensaio de tração dos corpos de prova de aço Hadfield sem refino e refinado solubilizados mostraram que houve um ligeiro aumento do limite de escoamento (6\%), que está em acordo com a equação de HallPetch, visto que materiais austeníticos possuem pequeno valor da constante de

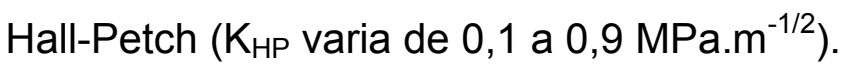

Os resultados do ensaio de tração da amostra de aço Hadfield com tamanho de grão refinado mostraram um aumento significativo nos valores de alongamento $(53 \%)$, de tenacidade $(88 \%)$, de resistência à tração $(37 \%)$ e do coeficiente de encruamento $(30 \%)$ com a redução do tamanho de grão. Austenítico. $O$ aço Hadfield refinado apresentou maior valor da energia absorvida no impacto Charpy $\left(179 \mathrm{~J} / \mathrm{cm}^{2}\right)$ em comparação com o aço Hadfield sem refino $\left(156 \mathrm{~J} / \mathrm{cm}^{2}\right)$. A melhoria nos valores destas propriedades não é previsto pela Lei de Hall-Petch, sugerindo a ocorrência de uma mudança de mecanismo de deformação plástica com o refino do tamanho de grão austenítico do aço Hadfield.

A caracterização fractográfica dos corpos de prova rompidos em tração e ensaio de impacto mostrou que o aço Hadfield sem refino e refinado apresentam fratura dúctil com presença de alvéolos e de maclas mecânicas. 
A caracterização microestrutural dos corpos de prova rompidos nos ensaios de tração e de impacto apresentaram maclas de deformação plástica, sendo que a densidade de maclas foi maior para o aço Hadfield refinado (35 \pm 5 maclas por $\mu \mathrm{m}$ no ensaio tração e; $42 \pm 4$ maclas por $\mu \mathrm{m}$ no ensaio de impacto) em comparação com o aço Hadfield sem refino (19 \pm 4 maclas por $\mu \mathrm{m}$ no ensaio de tração e; $24 \pm 6$ maclas por $\mu \mathrm{m}$ no ensaio de impacto).

Dessa forma, os resultados da caracterização microestrutural e dos ensaios mecânicos de tração e impacto mostram que o refino do grão favorece a atuação do mecanismo de deformação plástica por maclação.

A atuação mais intensa do mecanismo de deformação plástica por maclação causada pelo refino do grão austenítico melhorou a tenacidade $(88 \%)$, resistência à tração $(37 \%)$, alongamento $(53 \%)$, coeficiente de encruamento (30\%) e da energia absorvida no impacto (13\%) do aço Hadfield refinado. 


\section{REFERÊNCIAS BIBLIOGRÁFICAS}

ABBASCHIAN R; ABBASCHIAN L; REED-HILL, R. Physical metallurgy principles. Cengage learning, $2^{\circ}$ edição, 1964.

ADLER, P.H; OLSON, G.B; OWEN, W.S. Strain Hardening of Hadfield

Manganese Steel. Metallurgical and Materials Transactions A, vol. 17, $\mathrm{n}^{\circ} 10$, pp.1725-1737, 1986.

AGUNSOYE, J. O; ISAAC, S. T; ABIONA, A. A. On the Comparison of Microstructure Characteristics and Mechanical Properties of High Chromium White Iron with the Hadfield Austenitic Manganese Steel. Journal of Minerals and Materials Characterization and Engineering, pp. 24-28, 2013 (doi: http://dx.doi.org/10.4236/jmmce.2013.11005 ).

ALLAIN, S; ChATEAU, J. P; BOUAZIZ, O; MIGOT, S; GUELTON, N. Correlations between the calculated stacking fault energy and the plasticity mechanisms in Fe-Mn-C alloys. Materials Science and Engineering: A, vol. 389, nº 15, pp. 158-162, 2004.

ALYAZ, S. Effects of heat treatment and chemical composition on microstructure and mechanical properties of Hadfield steels. Dissertação de mestrado. Middleeasttechnicaluniversity, 2003.

ANDRADE, R. B; RAMCCIOTTI, R. E. L.Mineração e Economia verde. Encontro da indústria para a sustentabilidade, 2012.

APONBIEDE, O; SHEHU, U. An Overview of Hadfield's Steel for Rail Network and Allied Structural Applications. Ahmadu Bello University, Zaria.Nigeria, 2010. $4 \mathrm{p}$.

ARMSTRONG, R.; Codd, I.; Douthwaite, R.M.; Petch, N.J. The plastic deformation of polycrystalline aggregates. Phil. Mag. vol. 7, pp. 45-58, 1962.

ASHBY, M.F. Strengthening Methods in Crystals. Elsevier, Amsterdam, 1971.

ASTAF'EV, A. A. Effect of grain size on the properties of manganese austenite steel 110G13L. Materials science and heat treatment, vol 39, no 5-6, 1997.

ASM Handbook. Metallography and Microstructures, v. 15, 2004, 1184p. 
ASM Metals Handbook. Properties and Selection of Iron, Steels and High Performance Alloys, vol 1, pp. 1951-2003, 1993.

ASTM G128.A128. Standard specification for steel castings, austenitic manganese._ASTM international, vol. 93, 2012.

AVERY, H.S. Work Hardening in Relatio to Abrasion Resistance. Proceedings of the Symposium on Materials for the Mining Industry.Published by Clímax Molybdenum Company, p. 43, 1974.

AVERY, H.S. Austenitic Manganese Steel, Metals Handbook, v. 1, 8.ed., American Society Metals, 1961.

SUBRAMANYAM, D. K. (INC. E.; SWANSIGER, A. E. (CORPORATION A. R.; AVERY, H. S. (CONSULTANT). Austenitic manganese steel. In: ASM Handbook, vol. 1. [s.l: s.n.]. p. 1951 - 2004.

BAIN, E.C.; DAVENPORT, E.S.; WARING, W.S.N. The Equilibrium Diagram of Iron Manganese-Carbon Alloys of Commercial Purity. AIME Transactions, v. 100, p. 228, 1932.

BAYRAKTAR, E; KHALID F.A; LEVAILLANT C. Deformation and fracture behaviour of high manganese austenitic steel. Journal of Materials Processing Technology, vol. 147, n², pp. 145-154, 2004.

BENZ R; ELLIOTT, J. F.; CHIPMAN, J. Metallurgical transactions, vol. 4, pp. 1975-1986, 1973.

BENZ, R. Metallurgical transactions, vol. 5, pp. 2217-2224, 1974.

BHERO, S. W. et al. Common failures of Hadfield steel in application. International Conference on Mining, Mineral Processing and Metallurgical Engineering (ICMMME'2014), South Africa, 2014.

BRAMFITT, B. L. The Effect of Carbide and Nitride Additions on the Heterogeneous Nucleation Behavior of Liquid Iron. Metall. Trans., vol. 1, pp. 1987-1995, 1970.

CAHN, R. W; HAASEN, P. Physical metallurgy. Elsevier science, vol. 1, 1996. 
CALLISTER, D. W. Materials Science and Engineering: An Introduction. 8th edição, Hardcover, 2009.

CARTER, C.B; HOLMES, S. M. The stacking-fault energy of nickel. Philosophical magazine, vol. 35, n5, pp. 1161-1172, 1977.

CHIA, K. H; JUNG, K; CONRAD H. Dislocation density model for the effect of grain size on the flow stress of a Ti-15.2 at\% Mo -alloy at 4.2-650 K. Materials Science Engineering, A409, pp. 32-38, 2005.

CHUNG, Y. Introduction to Materials Science and Engineering. CRC Press, 304 páginas, 2006.

CHRISTIAN, J. W. The theory of transformations in metals and alloys. Pergamon, vol. 1, 2002

Computational Thermodynamics Inc, Pennsylvania, EUA. Simulação no Thermo-Calc com o banco de dados termodinâmico PBIN, 2011. Disponível em: http://www.calphad.com/iron-manganese.html. Acesso em 23/01/2017.

CONRAD, $\mathrm{H}$. Effect of grain size on the lower yield and flow stress on iron and steel. Acta Met. vol.11, pp. 75-77, 1963.

COOMAN, B. D; CHIN, K; KIM, J. High manganese TWIP steels for automative applications. New trends and developments in automative system engineering, pp. 1001-1128, 2011.

CURTZE, S; KUOKKALA, V.T. Effects of temperature and strain rate on the tensile properties of TWIP steels. Revista Matéria, vol. 15, n 2, pp. 157-163, 2010.

DASTUR, Y.N; LESLIE, W.C. Mechanism of Work Hardening in Hadfield Manganese Steel. Metallurgical Transactions A, vol. 12, pp. 749-759, 1981.

DEDAVID, B.; GOMES, C. I; MACHADO, G. Microscopia eletrônica de varredura: aplicações e preparação de amostras. Editora: EDIPUCRS, Porto Alegre, 2007. 
DUNSTAN, D. J.; BUSHBY, A. J.; LI, Y. The Hall-Petch as a manifestation of the general grain size. Proceedings of the royal society, vol. 472, 2016. DOI: 10.1098/rspa.2015.0890

FEIST, M. Thermal analysis: basics, applications, and benefit. $M$. ChemTexts,20015. doi: 10.1007/s40828-015-0008-y

FUOCO, R; HOLANDA, A. Processo de produção de componentes em aços ao manganês austeníticos do tipo hadfield. Congresso e Feira Latino-Americana de fundição- CONAF/FENAF, 2007.17p.

FUOCO, R. et al. Effect of Chemical Composition on the Carbide Reprecipitation Kinetics of Hadfield Austenitic Manganese Steel. Transactions of American Foundry Society, v. 120, n. 12-110, p. 507-522, 2012.

GHADERI, A.; Barnett M. R. Sensitivity of deformation twinning to grain size in titanium and magnesium. Acta Materialia, vol. 59, pp. 7824-7839, 2011.

GIRALDO, A. V. El acero Hadfield revisitado. Revista Colombiana de Materiales, no 3, pp. 1 - 24, 2012.

GLEITER, H. el al. Acta Materialia, vol. 16, p. 199, 1972.

GRÄSSEL, O; FROMMEYER, G. Effect of martensitic phase transformation and deformation twinning on mechanical properties of Fe-Mn-Si-Al steels. Materials Science and Technology, vol. 14, 1998.

GRONG, Ø. Metallurgical Modeling of Welding. 2nd Ed, The Institute of Materials, London, 1997.

HAAKONSEN, F. Optimizing of Strømhard austenitic manganese steel. Norwegian University of Science and Technology, 2009. 133p.

HADFIELD, R.A. Hadfield's Manganese Steel. Science, 1888. 12: p. 284-286

HALL, E. O. The deformation and ageing of mild steel: III-Discussion of results. Proc. Phys. Soc. Vol.64, pp. 747-753, 1951 (doi:10.1088/0370-1301/64/9/303). 
HANSEN, N. Hall-Petch relation and boundary strengthening. Center for Fundamental Research: Metal Structures in Four Dimensions, Materials Research Department, 2004. 6p.

HAM, Y. S; KIM, J. T; KWAK, S. Y; CHOI, J. K; YOON, W.Y. Critical cooling rate on carbide precipitation during quenching of austenitic manganese steel. China Foundry, vol. 7, no 2, 2010.

HILLER, M.; WALDENSTRÖM.Calphad, vol. 1, pp. 97-113, 1977.

HIRTH, J. P. The influence of grain boundaries on mechanical properties.Metallurgical Transaction, vol. 3, pp. 3047-3067, 1972.

HUANG, W.M., A thermodynamic assessment of the Fe-Mn-C system. Metallurgical Transactions a-Physical Metallurgy and Materials Science, vol. 21, pp. 2115-2123, 1990.

HUTCHISON, M. M. et al. Journal of Metals Science, vol. 6, no 90, 1972.

IBITOYE, S. A; OLAWALE J. O; SHITTU M. D. Mechanical properties of quench-hardened, martempered and tempered ASTM A128 Grade B-4 steel. Department of Materials Science and Engineering, Nigeria, 2005.

ISOBE, M. Sci. Rep. Res. Tôhoku University, vol. 3, pp. 540-620, 1951.

JILIN, C; SHIPENG, R; LIJUN, W; JINPO, Z; CHAO, L. Effect of austenite grain size on hardenability and impact toughness of SCM435H. Materials Science Forum, vol. 867, pp. 50-54, 2016.

JOSEPH, G. Scanning Electron Microscopy and X-ray Microanalysis. Springer, 2003.

KAKO, K. et al. Effect of various alloying elements on Tensile Properties of high purity Fe-18Cr- (14-16)Ni Alloys at Room Temperature. Materials Transactions, vol. 43, no 2, pp. 155-162, 2002.

KANG, J. $\mathrm{H}$ et al. Grain Boundary Strengthening in High Mn Austenitic Steels. The Minerals, Metals \& Materials Society, 2016 (doi:10.1007/s11661-016-33995. 
KARAMAN, I. et al. Modeling the Deformation Behavior of Hadfield Steel Single and Polycrystals Due to Twinning and Slip. Acta Materialia, vol. 48, pp. 20312047, 2000.

KESTENBACH, H.-J. . Efeito da Energia de Falhas de Empilhamento sobre a Deformação Plástica em Aços Inoxidáveis Austeníticos. Metalurgia Abm, São Paulo, v. 32, p. 181-186, 1976.

KIM, J. G; ENIKEEV, N; ABRAMOVA, M. M;PARK, B.H; VALIEV, R. Z; KIM, H. $\mathrm{S}$. Effect of initial grain size on the microstructure and mechanical properties of high-pressure torsion processed twinning-induced plasticity steels. Materials Science and Engineering A, vol. 682, pp. 164-167,2017.

KOCH, W.; KELLER H. Einsenhüttenwes, vol 35, pp. 1173-1180, 1964.

KRAUSS, G. Solidification, segregation and banding in carbon and alloy steels. Iron \& steel technology, pp. 145-157, 2004.

KUYUCAK, S; ZAVADIL, R; NEWCOMBE, P. Heat treatment of Hadfield's Austenitic Manganese Steels Part I - VIII.AFS Special Report, 2001.

LENCINA R. Optimization of high carbono austenitic manganese steels for comminution processes. Universitàde gli Studi di Padova, tese (doutorado) 2014.

LI, J. M. C. Hall-Petch relation and grain boundary sources.Trans. TMS 227, pp. 239-247, 1963.

LIMA, A. C; FERRARESI V. A. Avaliação de desgaste abrasivo de baixa tensão por roda de borracha em revestimentos duros soldados com arames tubulares. Universidade Federal de Uberlândia,2007.

LIMA, G. Influência dos elementos de liga no encruamento proveniente do processo de aplainamento nos aços hadfield. Faculdade de Engenharia de Bauru, dissertação (mestrado), 2011.

LIMOOEI, M. B; Hosseini S. Optimization of properties and structure with addition of titanium in hadfield steels. Metal, vol. 23-25, pp. 1-6, 2012. 
LLEWELLYN, D. T. Steels: Metallurgy and Applications. Elsevier, 314 páginas, 2013

MAHLAMI, C. S; PAN, X. An Overview on high manganese steel casting.Advanced sustainable foundry, South Afrika, 2014.

MARATRAY, F. High Carbon Manganese Austenitic Steels, Paris: International Manganese Institute, 1995.

MORRIS, J. W. The Influence of Grain Size on the Mechanical Properties of Steel. Department of Materials Science and Engineering, University of California, 2001.

NARUTANI, T.; TAKAMURA, J. Grain-size strengthening. Acta metallurgica, vol. 39, pp. 2037-2049, 1991.

NIELSEN, H. R. Hafnium and Hafnium compounds. Ullmann's Encyclopedia of Industrial Chemistry, 2000.

OGUIZA, C. Hadfield steel with Hf. European Patent.10382335.7, 2012. 5p.

OXFORD INSTRUMENTS. EBSD Explained - From data acquisition to advanced analysis, 2016. Disponível em: www.ebsd.com. Acesso em: 01/10/2016.

PANCHAL, K. Life Improvement of Hadfield manganese steel castings. International Journal of Scientific Development and Research College of, vol. 1, no 5, 2016.

PETCH, N. J. The Cleavage Strength of Crystals. Journal of Iron Steel Institute, vol. 174, pp. 25-28, 1953.

PORTER, D. A; EASTERLING, K. E; SHERIF, M. Phase transformation in metals and alloys. Springer Science, $3^{\circ}$ edição, 1992.

QIN, B; BHADESHIA H. K. D. H. Plastic strain due to twinning in austenitic TWIP steels. Materials Science and Technology, vol.24, n8, pp.969-973, 2007 
SANTANA, A. L. Manganês. Sumário Mineral, 2012. Disponível em: https://sistemas.dnpm.gov.br/publicacao/mostra_imagem.asp?IDBancoArquivo Arquivo=7528. Acesso em: 05/12/2016.

SANTOS, N. L. et al. Effect of Carbide Re-precipitation on the Toughness of Hadfield Austenitic Manganese Steel. American Foundry Society, pp. 1-16, 2010.

SASAKI, M. ET AL. Refinement of Austenite Grain in Carbon Steel by Addition of Titanium and Boron. ISIJ International, vol. $48, n^{\circ} 3$, pp. 340-343, 2003.

SCHUMANN, V. Martensitische Umwandlung in austenitischen ManganKohlenstoff-Stählen. Neue Hütte, vol. 17, pp. 605-609, 1972.

SEABRA, A.V., Correlação das Propriedades Mecânicas dos Aços com a Microestrutura, Lisboa, Memória Inec, n. 522, 1979.

SMALLMAN R. E; NGAN A.H.W. Modern Physical Metallurgy. Elsevier Science, $8^{\circ}$ Edição, 2014.

SMITH, R.W.; DEMONTE, A.; MACKAY, W.B.F. Development of highmanganese steels for heavy duty cast-to-shape applications. Journal of Materials Processing Technology, pp. 589 - 595, 2004.

SUBRAMANYAM, D. K. (INC. E.; SWANSIGER, A. E. (CORPORATION A. R.; AVERY, H. S. (CONSULTANT). Austenitic manganese steel. In: ASM Handbook vol. 1, pp. 1951 - 2004, 1961.

SIL'MAN, G. I. Phase diagram of alloys of the $\mathrm{Fe}-\mathrm{C}-\mathrm{Mn}$ system and some structural effects in this system. Part 1. Interphase distribution of manganese. Metalloved.Term.Obrab.Met., vol 47, no. 2, pp. 11 - 15, 2005.

SIL'MAN, G. I. Phase diagram of alloys of the $\mathrm{Fe}-\mathrm{C}-\mathrm{Mn}$ system and some structural effects in this system.Part 2. Interphase distribution of manganese. Metalloved.Term.Obrab. Met., vol.47, no. 4, pp. 3- 9, 2005.

SIL'MAN, G. I. Phase diagram of alloys of the Fe - C - Mn system and some structural effects in this system. Part 3. Interphase distribution of manganese. Metalloved.Term.Obrab.Met., vol. 47, no. 9, pp. 397-401, 2005. 
SINGH, M. et al. Grain-size effects on the thermal conductivity of nanosolids. Journal of Taibah University for Science, 2015.

SMITH, W. F.; HASHEMI, J. Foundations of Materials Science and Engineering 4th edição, McGraw-Hill, 2006.ISBN 0-07-295358-6.

SRIVASTAVA, A. K; DAS K. Microstructural characterization of Hadfield austenitic manganese steel. Journal of Materials Science, 2008 (doi: 10.1007/s10853-008-2759-y 2008).

THERMOCALC. Banco de dados do Thermo-Cal.TCFE8: ThermoCalcSteels/Fe-Alloys v.80 e SSOL4- AlloySolutions v.49g, 2016. Disponível em:

http://www.thermocalc.com/media/10864/dbd_tcfe8.pdf

http://www.thermocalc.com/media/10306/dbd_tcfe8_extendedinfo.pdf

http://www.mie.uth.gr/ekp_yliko/TC_Database_Guide.pdf

TSAKIRIS, V; EDMONDS, D.V. Martensite and deformation twinning in austenitic steels. Materials Science and Engineering A, pp. 430-436, 1999.

TSUJIMOTO, N. Casting Practice of Abrasion Resistant Austenitic Manganese Steel. AFS International Cast Metals Journal, pp. 62-77, 1979.

TWEEDALE, G. Sir Robert Abbott Hadfield F.R.S. (1858-1940) and the discovery of manganese steel. Notes \& Records of the Royal Society.vol. 40, pp. 63-74, 1985.

VOGEL, R.; DORING, W. Arch. Eisenhüttenwes, vol. 9, pp. 247-252, 1935.

XIONG, R; PENG, H; WANG, S; SI, H; WEN, H. Effect of stacking fault energy on work hardening behaviors in Fe-Mn-Si-C high manganese steels by varying silicone and carbon contents. Materials and Design, no 85, pp. 707-714, 2015.

WANG, L. et al. Effect of hafnium carbide on the grain refinement of $\mathrm{Mg}-3$ wt. $\%$ Al alloy. Journal of Alloys and Compounds 500, 2010. 
YELEUSSIZOVA, A .A; SKAKOV, M.K; ZHILKASHINOVA, A.M; ROFMAN, O.V. Deformation twinning in Hadfield steel. Advanced materials research, vol. 77 n², pp. 62-67, 2013.

ZHU, T. T.; BUSHBY, A. J.; DUNSTAN, D. J. Materials mechanical size effects: a review. Materials technology, vol 23, 2008 (doi: 10.1179/175355508×376843).

ZHU, T. Z. et al. Grain size effect on deformation twinning and detwinning. Journal of Materials Science, vol. 48, pp. 4467-4475, 2013. 